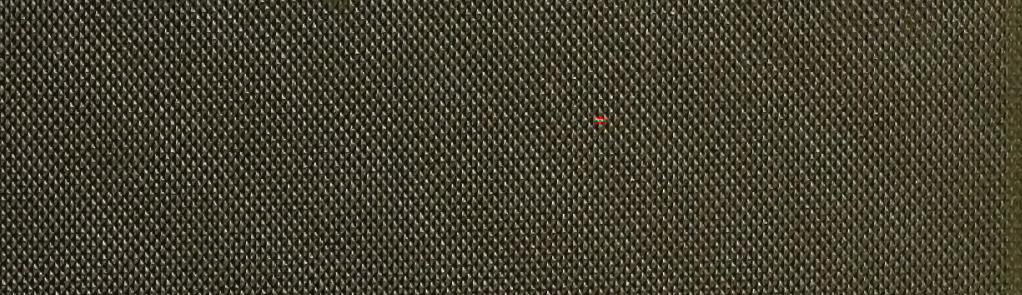




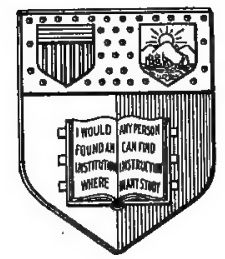

New York

State College of Agriculture At Cornell University

Itbaca, N. Y.

\section{Library}




\section{QL 48.C8 Cornell University Library}

A text-book of field zoology; insects and

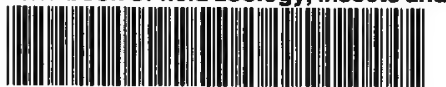

31924003390931 


\section{Cornell University Library}

The original of this book is in the Cornell University Library.

There are no known copyright restrictions in the United States on the use of the text.

http://www.archive.org/details/cu31924003390931 




FIELD ZOOLOGY

CRARY 



\title{
A TEXT-BOOK OF
}

\section{FIELD ZOOLOGY}

INSECTS AND THEIR NEAR

\section{RELATIVES AND BIRDS}

BY

LOTTIE E. CRARY

ASSISTANT PROFESSOR OP BIOLOGY AND GEOLOGY, KANSAS STATE NORMAL COLLEGE, EMPORIA.

WITH ONE HUNDRED AND SEVENTEEN ILLUSTRATIONS

\author{
PHILADELPHIA \\ P. BLAKISTON'S SON \& CO.
}

1012 WALNUT STREET 
Copyright, igio, By P. Blakiston's Son \& Co. 


\section{AUTHOR'S PREFACE.}

- This book is intended primarily for students who have had little previous knowledge of insects, or animals of any sort. The animals chosen for discussion have been the more familiar ones which live with us from day to day. Two modes of approach to the subjects of study are intended: the investigative study of the animals themselves, as provided for in the directions for field work with the different groups of animals; and the class discussions of the facts observed, in their bearing upon each other and upon the many problems which living beings are continually offering for our solution. In the latter phase of study the teacher must be a large factor. One cannot put into a text-book all there is in a subject The present form of the book is the outcome of its progressive use in the school-room, and thus has, at least, the merit of having been tried.

The method of presentation of the subject is based upon two lines of belief: first, that life is one of the most interesting facts of creation, if not the most interesting; and, second, that life is a continuous fact, of common powers but various in its expression, whether one proceeds from the simple to the complex, from the early to the late, or from the low to the high. These are facts that are usually reserved for the student who has already acquired some body of knowledge of animal life; but younger students, beginners, find quite as much delight and profit 
in the discovery of their own similarities to forms of life unlike themselves, and in the fact that life powers are not theirs by right to the exclusion of other animals, which may even transcend them in some of these powers.

The writer stands indebted to several authors whose work has covered a much larger field, notably Comstock, Folsom, Galloway, and Kellogg; and the many excellent workers in the Government Biological Survey and the Bureau of Entomology. Courteous permission was given to use various illustrations, by Henry Holt \& Co., by Doubleday, Page \& Co., of New York, and by James T. Hathaway, of New Haven, Conn. 


\section{TABLE OF CONTENTS.}

\section{PART I.}

INSECTS.

CHAPTER

I.-Introduction to insects ... . . . . . . I

II.-Special senses of insects . . . . . 7

III.-Vital processes of insects. . . . . 20

IV.-Development and metamorphosis . . . $3^{2}$

V.-Insects and their classification . . . . 42

VI.-General suggestions for field work on insects. . . . . . . . . . . 46

VII.-Field work on Coleoptera . . . . $\quad 59$

Coleoptera . . . . . . . . . . . 67

VIII.-Field work on orthoptera . . . 79

Orthoptera . . . . . . . 87

IX.-Field work on hemiptera . . . . . 98

Hemiptera . . . . . . . . . . . I07

X.-Field work on lepidoptera . . . . I 9

Lepidoptera . . . . . . . . . I25

XI.-Field work on hymenoptera . . . I 39

Hymenoptera . . . . . . . I49

XII.-Field work on diptera . . . . . . 176

Diptera , . . . . . : . . . 183

XIII.-Odonata . . . . . . . . . 207

XIV.-Ephemerida . . . . . . . . 2 II3

XV._Plecoptera. . . . . . . . $2 \mathrm{I} 7$

XVI.-Neuroptera . . . 22 I

XVII.-Siphonaptera . . . 226 


\section{PART II.}

Arthropoda Exclusive of Insects and Crustaceans.

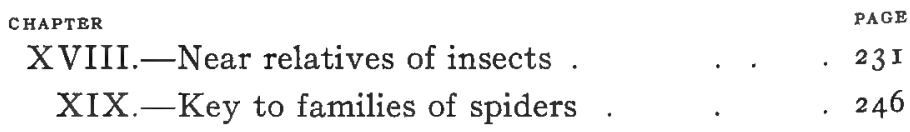

PART III.

Birds.

- XX.-General suggestions for field work on birds 249 XXI.-Introduction to birds . . . $25^{2}$

XXII.-Physical features of birds . . 262

XXIII.-Migrations and nesting habits . 274

XXIV.-Food of nestling birds . . . . . 287

XXV.-Nervous system and special functions $\quad 296$

XXVI.-Passeres . . . . . . . . 307

XXVII.-Picariæ . . . . . . 312

XXVIII.-Psittaci . . . . $3{ }^{16}$

XXIX.-Raptores . . . 318

XXX.-Columbæ . . . . 320

XXXI.-Gallinæ . . . . . . . . . . . 322

XXXII.-Limicolæ. . . . . . . 327

XXXIII.-Herodiones. . . . . . . $33 \mathbf{I}$

XXXIV.-Alectorides . . . . . . . 334

XXXV.-Lamellirostres . . . . . . . 337

XXXVI.-Steganopodes. . . . . . . . : . 343

XXXVII.-Longipennes . . . . . . . 347

XXXVIII.-Pygopodes . . . . 350

INDEX . . . . . $\quad 357$ 


\section{LIST OF ILLUSTRATIONS.}

FIG.

I. Skull of a grasshopper . . . . . . . 4

2. Portion of compound eye of a fly . . . . . . 8

3. Median ocellus of a honey bee. . . . . . . : . . 9

4. Antenna of a carrion beetle . : I 2

5. Tactile hair . . . . . . . I4

6. Nerve endings in tip of labial palpus of a fish moth. I6

7. Ear of a grasshopper . . . . . . . . . . . . I77

8. Locust from lateral aspect, auditory organ . . $\quad$ i 8

9. Auditory hairs of a mosquito . . 18

Io. Antenna of a mosquito . . . . . . . . . . 19

I I. Tracheal system of an insect. . . . . . . 2 I

I 2. Tracheal gill of a Mayfly . . . . . . . . 22

I3. Digestive system of a beetle. . . . ${ }_{25}$

I4. Stages in development of nervous system of a dipter water beetle $\quad . \quad$. . . . 29

I 5. Concentration in nervous system of a dipter. . 30

I6. Hypermetamorphosis of Epicauta cinerea . . . 34

I7. Larva of tomato worm . . . . . . 35

I8. Pupa of tomato worm . . . . . . . . $3_{3}^{6}$

I9. Adult of tomato worm . . . . . 37

20. Development of squash bug. . . . . . . 4 I

2 r. Diagram of insect net. . . . . . . . . . . 49

22. Dip net . . . . . . . . . . 50

23. Drying board . . . . . . . . . . 55

24. Great water scavenger . . . . . . 6 I

25. Egg case of water scavenger . . . . . 6 I

26. Larva of water scavenger . . . . . . . . . 62

27. A flower beetle, Euphoria inda. . . . . . . 62

28. Some California ladybird beetles . . . . . 70

29. The searcher . . . . . . . . . . . . . 7 I 
FIG.

30. Ventral aspect of a carabid beetle . . . . . . $7^{2}$

3I. Various forms of antennæ . . . . 75

32. Legs and tarsi of beetles . . . . . . . $7^{6}$

33. Metamorphosis of a beetle, Cyllene pictus 77

34. Hypermetamorphosis of Epicauta cinerea ${ }_{78}$

35. Locust with external parts named . . . . . 88

36. Short-horned grasshopper . . . . . . . 89

37. Long-horned grasshopper . . . . . . 90

38. Cricket-like grasshopper. . . . . . 9 I

39. Croton bug . . . . . . . . . . . . . 93

40. Oriental cockroach . . . . . . . . . 93

4 I. Native cockroach . . . . . . . 94

42. Praying mantis . . . . . . . . 95

43. Dapheromera femorata . . . 96

44. Giant waterbug . . . . . . . . . . 100

45. Development of a cicada . . . . . . . I03

46. Front wing of an hemipter . . . . . 107

47. Mouth parts of an hemipteron. . . Io8

48. Short-winged chinch bug . . . . . $\quad$ I I3

49. Soldier bug . . . . . . . . . . . I I7

50. Assassin bug . . . . $\quad$ I I 7

5 I. Lepidopter wing to show scales . . . . I 25

52. A, front wing of monarch butterfly to show venation . . . . . . 126

$B$, hind wing of monarch butterfly to show venation . . . . . . . I . 26

53. Head of a butterfly. . . . I 27

54. Adult of tomato worm . . . . . . . I 28

55. Sphinx moth at petunia flower . . . . . I 28

56. Wing of moth to show jugum . . . . I 29

57. A, wing of moth to show frenulum . . . . I30

$B$, wing of butterfly to show frenulum substitute. r 30

58. Artificial ant nest .. . . . . . . . . I 43

59. Thalessa linator . . . . . . . . . I 5 I

6o. Pigeon horntail . . . . . . I 52 
FIG.

61. Mouth parts of a honey bee

I 53

62. Tongue of a honey bee . . . . . . . . . . I 53

63. Head and mouth parts of a honey bee 156

64. Honey bee, worker, etc . . . . . . . . . . . I 58

65. Portion of brood comb of honey bee, one queen cell I 59

66. Modifications of leg of worker honey bee . . . 162

67. Nest of mud dauber . . . . . . . . 163

68. Honey bee showing wax scales . . . . 169

69. Cicada killer . . . . . . . . . . . . . . 169

7o. Tarantula killer. . . . . $\quad$ I70

7 I. Nest of paper wasp . . . . . 174

72. Blow fly . . . . . . . . . . . . I I77

73. Mouth parts of a horse fly $\quad$ I 84

74. Antennæ of flies . . . . . . . . . . . . . . . 185

75. Ocelli and compound eyes of a fly $\quad$ I 86

76. Metamorphosis of an oviparous fly, Phormia regina 187

77. Stable fly . . . . . . I 89

78. Mouth parts of house fly . . . . . . . I89

79. Foot of a house fly . . . . . . I90

80. A house fly . . . . . . . . . . . I90

8I. Mouth parts of a female mosquito . . . . . . . I94

82. Life history of a mosquito . $\quad 195$

83. Female Anopheles with antenna of male . . 197

84. Antennæ of a mosquito (Culex) . . . . . . . . I99

85. A flower fly. . . . . . . 201

86. A bee fly . . . . . . . . . 203

87. Stages in development of a dragon fly . . . . . 210

88. Nymph and adult of a May fly. . . . 2 I 4

89. Nymph and adult of a stone fly . . . . 2 I8

9०. Lace-wing depositing eggs . . . . . . . . . 222

9r. Larva of a dobson . . . . . . . . 223

92. Adult dobson . . . . . . . . . 224

93. A mantispa . . . . . . . . . . 225

94. Egg, pupa, and adult dog flea . . . 228

95. A milliped . . . . . . . . . . . . . . . . 232 
PIG.

96. A centiped . . . . . . . . . . . 233

97. A scorpion . . . . . . . . . 237

98. The archæopteryx . . . . 254

99. Conirostral bill of a canary . . 262

Ioo. Falcatee bill of a crossbill . . . . 262

Iог. Fissirostral bill of swallow . . . . . ${ }_{2} 6_{3}$

ro2. Fissirostral bill of a chimney swift . . . . ${ }^{26} 3$

ro3. Hooked and cered bill of a hawk . . . 263

I04. Tenuirostral bill of a nuthatch . . 264

I05. Hind limb or leg and foot of a bird . . . 265

I06 Front limb or wing of a bird . . . 270

I 7. Typical passerine foot . . . . . . 307

ro8. Loggerhead shrikes . . . . . . 309

I 09. Syndactyle foot of a picarian bird . . . 3 I 2

I Iо. Belted kingfisher . . . . . . . 314

I I . Zygodactyle foot of a parrot . . . . 3I7

I I 2 Semipalmate foot of a plover . . . 328

I I3. Lobate foot of a coot . . 336

I I 4. Wood duck . . . . . . . . . 34 I

I I 5. Totipalmate foot of a pelican . . . . . . 344

I I6. Pelican . . . . . . . . . . 345

I I7. Palmate foot of a tern . . . . . . . . 347 


\section{PART I. \\ INSECTS.}

\section{CHAPTER I.}

\section{INTRODUCTION TO INSECTS.}

\section{Biology.}

Biology, the word, is made from the two Greek nouns bios, meaning life, and logos, meaning speech, reason, word, that is, something given with authority. Hence biology discusses life in its many phases, its structural means of maintaining itself, and its power of perpetuating itself from one generation to another. Biology, then, concerns itself with both plants and animals, and we have.plant biology and animal biology.

\section{Zoology.}

Zoology is built from the two Greek nouns zoon, meaning an animal, and logos; hence zoology is the discussion of animal life in its many phases of activity and power. The systematic zoologist divides the many forms of animal life into branches according to their large similarities and dissimilarities. He may, for example, establish the two classes, Protozoa-one-celled, non-differentiated animals, very simple in structure; and Metazoa-many-celled 
animals, many of them highly differentiated. Under the second class, he may establish such branches as the Colenterata, animals with a continuous body cavity, this cavity having but a single opening, which serves both as mouth and as anus; Echinodermata, animals of radiate structure, no backbone, and the body surface beset with spines (from echinos, a hedgehog, and dermos, skin); Mollusca, including such animals as snails and clams; Arthropoda, animals with organs of locomotion jointed in successive segments, literally joint-footed (from arthron, meaning joint or articulation, and poda, meaning organs of locomotion); and Chordata, animals having a nervous cord, or a backbone, or both. The last-named branch includes such animals as the sea squirts with only a nervous cord; and the fishes, the frogs, the reptiles, the birds, and the mammals, with a vertebrate skeleton.

This work confines itself to the study of portions of two of these branches - the Arthropoda; and the Aves, or birds, under the Chordata. Under the branch Arthropoda are found insects, scorpions, mites and ticks, millipeds and centipeds, spiders, and the large class of the crustaceans. The crustaceans will be left for consideration elsewhere, and we shall confine our study to the insects with their near relatives, and birds.

The class Insecta includes only the insects, and it is itself divided according to the similarities and dissimilarities of the many kinds of insects.

The name insect is applied to such animals as have the body cut into successive segments. These segments are for the most part grouped so as to form three general regions, the head, the thorax, and the abdomen. The whole body may be composed of distinct and similar segments, as in the caterpillar; or may be greatly modified 
to serve some special purpose, as in the honey bee. The segments composing the head are, in most insects, so fused as to form a single box-like head-covering of one sclerite only. In the larva, the separate head sclerites are usually to be found. The three segments forming the thorax are, in many insects, so fused as to be separated with difficulty; but are observable in the generality of insects, being seen most easily on the under side of the body. Catch two or three large jumping grasshoppers, the sort that do not fly so well as they jump. Put one into the killing-bottle and let it stay there while you examine the others. Seize one of them by the abdomen-carefully -and you will be likely to realize the strength of the muscles of its strong hind legs. If human beings were able to kick as vigorously in proportion to their size, woe to their enemies! There would be left neither vestige nor trace. Let the hopper try its jaws on your finger, and you will sense the efficiency of leverage in the jaw muscles. Set it on the table and measure the length of its jump. This indicates good muscle, and stiff skeleton for fastening the muscles to. All grasshoppers are injurious, so no harm will be done by putting these into the killing-bottle after finishing the experiment. Now take out the other hopper from the killing bottle, and with a sharp knife sever the thorax from the abdomen; cut off the head also, and let fresh water run through the thorax till all the soft internal parts are washed away. What is left will be chiefly muscular tissue, the complex muscular system of the thorax. Accompanying these muscles may be seen the white fibers of the nervous system, but the muscular tissue may be plainly seen, part of it consisting of strands fastened to the top sclerites of the thorax, part fastened to the sides, and part crossing to reach the first joint of the 
leg on either side, while still another part of the mass will be found to pass laterally to attach to the ribs of the wings.

Now for the mouth parts: Give your living grasshopper a fresh young grass leaf, and watch it through the reading-glass. On the head will be found several pairs of jointed organs with which it seizes and handles the leaf.
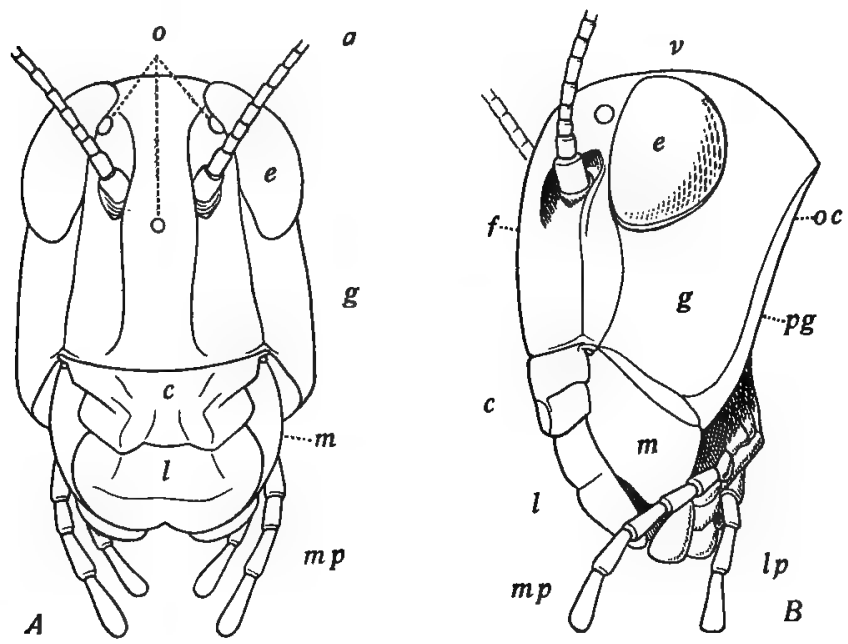

FIG. 1.-Skull of a grasshopper, Melanoplus differentialis. a, antenna; $c$, clypeus; $e$, compound eye; $f$, front; $g$, gena; $l$, labrum; $l p$, labial palpus; $m$, mandible; $m p$, maxillary palpus; $o$, ocelli; $o c$, occiput; $p g$, post-gena; $v$, vertex. (Folsom.)

The mandibles are first used; they seize the leaf; the maxillæ break up the green bits into smaller pieces; then is seen the labium or under lip, which seems to have no further use than to turn the food bits round and round and keep them from falling out of the mouth. Besides these, at the side of the mouth opening and well in front, are two pairs of hair-like appendages which are constantly 
in motion in and out of the food mass; these are the palpi or feelers; one pair is attached to the labium and the other pair to the maxillæ. It is thought that there are developed on these palpi of the grasshopper the taste buds which give the insect its taste impressions, its sense of relish or disapproval of the food under consideration.

On the front of the head, well toward the eyes, are the antennæ, and these are sense organs for all insects, though not giving the same sensation in all cases. Touch the antenna of your grasshopper very lightly, and it gives a quick jerk. Threaten without striking, and, if the insect does not jump away, the same response will be given. Make a loud noise near the insect's antennæ, and the antennæ will wave about as if in response. As to other insects, some use the antennæ as ears, while others use them as noses. The true uses of the grasshopper's antennæ are not known. Here is an opportunity for someone with time and patience, to discover a valuable fact.

As to the abdomen, in most adult insects the abdominal segments are fairly distinct and similar, thus retaining the form of the primitive type of insect; for in insects, as in all animals, the simplest form is the undifferentiated or similarly-segmented type or individual.

The insect's body wall is cuticle, but it is rendered firm and horny by the addition of a substance called chitin, a substance which serves for the protection of the soft internal organs, and also for the attachment of the many muscles necessary in running, flying, fighting, homemaking, and other activities of insect life. There is no internal skeleton, but the chitinized cuticle serves the purpose of an exoskeleton. From this exoskeleton, especially in the thorax, many processes of the body wall project inward for the attachment of the muscles of the 
wings and the legs. The insect's body wall is rendered flexible by the fact that between any two segments there is a non-chitinized area; these chitinized areas with the non-chitinized areas between constitute sclerites, and the degree of flexibility depends upon the depth of the infolding of the soft, non-hardened cuticle between any two sclerites.

Looking the grasshopper straight in the face, there will be seen a sclerite coming down from the upper part of the face and nearly covering the mandibles, the maxillæ, and the other mouth parts. This is the labrum or upper lip; it is hardly to be called an appendage of the mouth, but is rather a fold of the cuticle covering the mouth. The mandibles usually consist, as in the grasshopper just studied, of one segment. The labium usually forms one single piece, but in many of the insects it is modified into several pieces, as in the flies, the bugs, and the butterflies. In certain insects, some of the other mouth parts may be reduced to mere rudiments or may be lost altogether, not developed because functionless.

At the side of the grasshopper's head may be seen the large compound eyes. With a hand lens these will be seen to be composed of a large number of very small flat faces, instead of forming one smooth, globular surface like the human eyeball. Just inside the margin of each compound eye may be found two of the simple eyes, and lower down in a groove of the grasshopper's face is the third simple eye. These look like tiny beads. A housefly has three of these simple eyes, but they are set in a much smaller triangle between the two compound eyes and more nearly on top of the head. 


\section{CHAPTER II. \\ SPECIAL SENSES OF INSECTS.}

\section{Sight.}

Both simple and compound eyes are found on most insects; but some have either kind alone, and a few have no eyes at all. The most primitive living insects to-day have eyes, and the larvæ of the complex insects have simple eyes. Hence, if the highest individual in any given class repeats the life history of the individuals below it, it is only fair to suppose that the possession of eyes is inherent in all insects; and, where there is a lack of eyes, it must be attributed to disease or some other environmental conditions bringing about non-development or disuse, and therefore degeneracy of the part not used.

The compound eye is not an aggregation of simple eyes; the two sorts of eyes differ in structure, and there is good evidence that they are not derived from the same line of body differentiation. The compound eyes of insects are two in number, and are usually situated on the upper head areas, a little to one side of the middle line. They are usually conspicuous; in the dragon fly and the house fly they are large in proportion to the rest of the head. The dermestidæ, the pests of the insect collector, count the head of a dragon fly a rich treat and will eat out the soft internal parts, leaving the corneal facets quite clear. Many insects, as the butterflies, the dragon flies and the house flies, have an enormous number of facets, 
in some insects numbering as high as thirty thousand. Behind each facet is an eye element which is supposed to enter the nerve tract by a separate nerve fiber. This eye element includes a cone of crystalline clearness, with the tapering end enveloped more or less completely by pigment. Behind each cone are retinal cells, ganglionated nerve

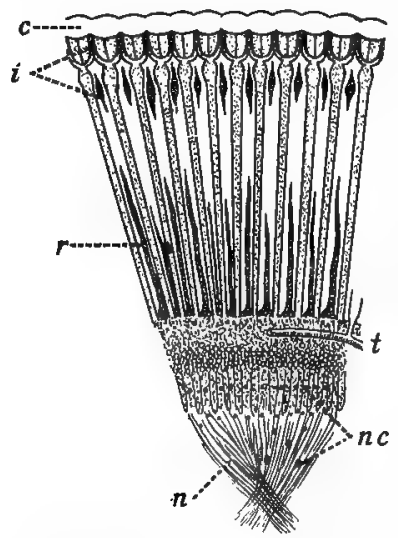

FIG. 2.-Portion of compound eye of fly, Calliphora vomitoria, radial section. $c$, cornea; $i$, iris pigment; $n$, nerve fibers; $n c$, nerve cells; $r$, retinal pigment; $t$, trachea. (Folsom, after Hickson.) in no such sense as has the human being; but the visual impression must be a composite of the image, made up of as many parts as there are corneal facets on the side of the head next to the object. Such sight is called mosaic sight. It would follow, then, that insects whose eyes project much beyond the head contour, which possess the largest number of facets, and which, in addition, can turn the head through the greatest possible angle, must have the 
most nearly complete mosaic of the object at which they look, that is, come nearest to seeing as we ourselves see.

The simple eye appears externally as a convex beadlike object, and as such is a transparent area of the head cuticle, thickened so as to protrude from the surface of the head. This makes a lens, convex on the outer side and indicating that, by means of the simple eyes, such sight as the insect has must be nearsight. Through this lens the light rays pass to a layer of specialized skin cells with pigment present. Directly back of the lens there is also a more or less developed vitreous body, its development varying with the order of insects. Fibers from the cells of the pigment layer merge into the tract of an optic nerve branch passing to the cephalic

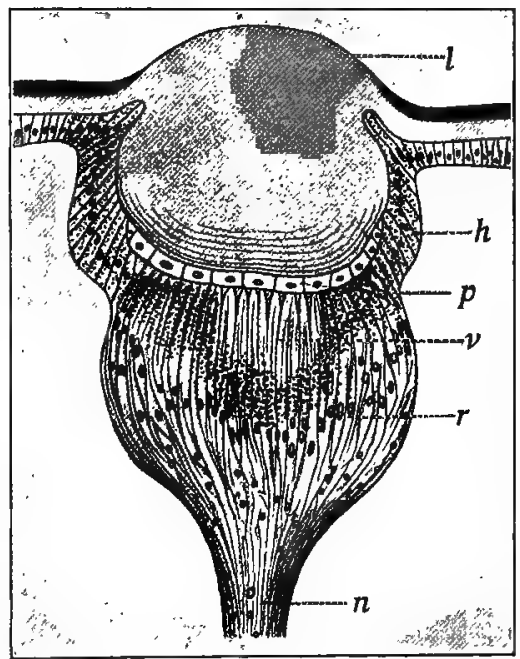

FIG. 3.-Median ocellus of honey-bee, Apis mellifera, in sagittal section. $h$, hypodermis; $l$, lens; $n$, nerve; $p$, iris pigment; $r$, retinal cells; $v$, vitreous body. (Folsom, after Redikorzew.) ganglion.

The eye is a part of the nervous system, and the nervous system arises as a differentiation of the surface cells of the animal of primitive type. For instance, in the sponge, where the body is like a sack, the body consists of three layers, two of them in contact with the water in which the sponge lives. The outer one of these layers, the ectoderm, discharges the functions of our tactile 
corpuscles, not to speak of functions attributed to other organs of ours, as those organs that give us the sensations of light and darkness, heat and cold, all of them differentiated parts of our complex nervous system. The cells of the interior layer of the body, the entoderm, perform the functions of our highly elaborated alimentary system, while the skeleton of the sponge is the product of the working energy of the middle layer of cells, the mesoderm. This general division of functions holds true for other animals from the sponge to the complex animals; the primitive ground sense, not localized, but distributed over the body surface in the simple animal, becomes the nervous system of the more complex animal and is there differentiated into touch, sight, taste, hearing, smell, temperature, and other sensations believed to be interpreted by the reflex or the spinal system. But an organ, on its first appearance, is little differentiated from the surrounding tissue, and only gradually reaches higher levels of perfectness; hence the simple eye is probably an earlier expression of a light sensitive, chiefly useful in distinguishing light from darkness; while the compound eye may be said to represent a later and more complex organ of sight. The function of the simple eye is not certainly known. In those animals which see most definitively, that is, which come nearest to forming a perfect image, the simple eye has gone through no development from its primitive structure, while the compound eye, in these insects, has the greatest number of facets, seeming to indicate that the compound eye is the effective organ of sight.

Again, as to the simple eye: wherever in any animal, simple or complex, pigment is present in the skin cells, those cells must be sensitive to light; that they are so 
may be proved in several ways. For this reason scientists are disposed to regard the simple eye rather as an organ sensitive to differences in the amount of light falling upon them. This light sense is a dermal possession of many of the lower animals; some of the minute one-celled animals living in the water respond to changes in the light intensity. The earthworm, with no eyes at all, is sensible of the fact that it has come above ground, and turns downward again. Your own skin; exposed to sunlight, responds to the action of the light without any volition of yours, and you say that you freckle or tan. Bees sometimes know their hive by the color; whether this sense plays any part in the wonderful "homing instinct" of these insects is not certain, but they use this sense in seeking food, as do many other animals, insomuch that we say bees prefer certain colors of flowers, while flies as a rule prefer other colors. It seems likely that butterflies' bright colors are useful as recognition marks to guide others of their kind. A clue as to the other possible uses of bright markings on butterflies' wings may be found in the fact that the wings of old butterflies are frayed and often have pieces torn from them, as if bird enemies had aimed for the wing spot instead of for some more vital part.

\section{Smell.}

Smell is a sense highly developed among insects. Among bees and ants the development of this sense seems not equalled elsewhere in the animal kingdom. Who has not at some time seen ants swarm in from some unknown place toward the sugar jar or the plate of frosted cake? It could not have been chance, for their path led through many difficulties. Honey bees have been 
known to find a plate of honey left on the kitchen table. A human being could hardly have smelled the honey at close range. In the case of human beings, the olfactory nerve of one person may carry stimuli for certain odors, and not be at all responsive for other odors. Again, it is difficult for a human being to discriminate between

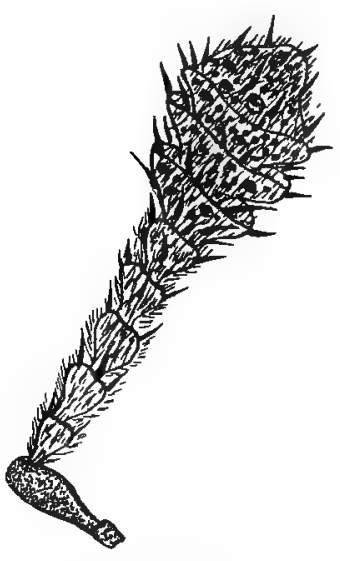

FIG. 4.-Antenna of a burying beetle, Necrophorus Americanus, showing sense pits in end segments. odors somewhat similar, as odors of different flowers, different teas, or different foods. Personal cleanliness generally obliterates for us. any olfactory recognition mark of our own race; and yet the approach of a member of a different race is an instant olfactory suggestion.

Out of all this must come this concession: the fact that we do not perceive an odor does not prove that the olfactory sense of some other living being may not respond to it.

The immediate smelling organs in the case of insects are exceedingly small papillæ or pits, at the bottom of which a fiber from the olfactory lobe of the brain ganglion is spread under the thin body tegument. These organs are often found on the antennæ. Carrion beetles have what seem to be unmistakably olfactory organs on their antennæe and also on their palpi. Flesh flies, which are so often attracted considerable distances by the odor of decaying meat, lose this means of finding their food after their antennæ are removed (Hauser). Many moths use this sense as a means of recognition of the other sex, and have been proved by experiment to be unable 
to find their mates when the antennæ have been removed or coated. On the wings of the big red-brown monarch butterfly are pockets in which are carried scent scales. Ants are thought to be able to perceive odors in so far as to recognize members of their own colony, the path over which a nest-mate has passed or which they themselves have recently traversed, and to know an enemy by the fact that the new ant smells different from their nest-mates.

There are plenty of instances which might be cited to prove that man is really inferior to many of the lower animals in the small range of discrimination possible in his olfactory sense. The elephant, the deer, the fox, the wolf, the dog, all bear evidence to an olfactory sense wonderful in its development. Our impressions of delight, aversion; comfort, danger; friend, foe, are more often the result of mental processes. In most affairs of life we think why we should feel, rather than instinctively feel without thinking. Yet, in cases so new that no previous experience could reason out an explanation, we may act from instinctive feeling-we say that we scent danger. There is no question that this sense played an important part in the life of primitive man as it does today in the preservation of lower animals. It is certain that some insects, at least, if not the majority of them, find their food by the sense of smell. The food-getting instinct is probably the lowest though the most valuable of the instincts, and the sense of smell is surely one of its valuable servants.

\section{Touch.}

The sense of touch is, with human beings, entirely a superficial sense, a contact sense, capable of stimulation 
through specialized cells lying just under the epidermis, more abundantly scattered in some portions of the body than in others. We do not feel at all just over the elbowjoint, and much less feebly on the cheek than on the lips. But there are other means of contact sense. Close your eyes and let some friend touch one of the hairs on the back of your hand or arm, and you have the immediate

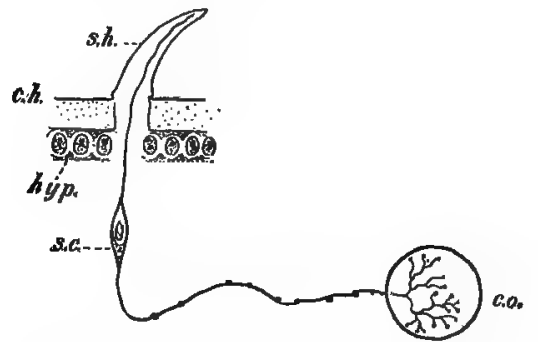

FIG. 5.-Diagram showing innervation of a tactile hair. ch, chitinized cuticle; $h y p$, cellular layer of skin; $s c$, ganglion cell; co, ganglion of central nervous system. (Kellogg, after vom Rath.) sensation of having been touched. A fine nerve at the base of this hair communicated to your brain the stimulus of contact. In this latter way, insects are provided abundantly with the contact sense. (Fig. 5.) Catch a house fly, and you will find a number of stiffish hairs on the surface of the body. Lightly touch one of these hairs, and you may be able to prove to yourself that they are actually tactile hairs. Most insects have these hairs in greater or less abundance. There are hairs on some insects which serve other purposes, such as the stiff hairs on the hind legs of some of the swimming beetles, or the auditory hairs, but possibly even these are contact sense organs in addition to their other use. Where the body wall of an insect is thickly chitinized, unless the chitin armor is pierced by one of these hairs, the insect seems feebly, if at all, sensitive to touch. A praying mantis on the desk of the author was exploring a bunch of golden-rod, and was confronted by a woolly bear, one of the hairy brown cater- 
pillars with a broad black band around its body. The mantis put up her front feet in the usual attitude and the caterpillar promptly took hold of the tarsi. Nothing happened until the caterpillar bit viciously at the mantis's foot, when she jerked her foot away and ran off, going on five legs and holding up the sixth, much as a dog holds up an injured member.

In an insect the tiny nerve at the apex of the hair runs down under the skin to a knot of nervous matter, and from there a nerve fiber runs to a nerve ganglion for that particular segment on which the hair is located. The ganglion is a part of the whole nervous system, as will be proved by the fact that the insect may will to run away as the result of this excitation of one of its tactile hairs, or it may will to turn about and show fight. Try this on a caterpillar, removing as far as possible the chance of its seeing you and thus becoming frightened in that way.

This is different from the usual conception of the human nervous system, where all impressions are supposed to be referred to the forward end of the nerve axisthe brain-for interpretation. But we are coming to realize, through more intelligent study, that there are plenty of stimuli coming in upon our nervous system, which are interpreted before reaching the cerebrum; in fact, so far as late investigators can determine, some stimuli never reach the brain at all, but pass into action upon being interpreted elsewhere. This, being true, proves again the similarity of life activities. Our life is, at foundation, of the same sort as the life of these simpler creatures; only in us it finds more varied means of expression. 


\section{Taste.}

The taste organs of insects occur in the roof of the mouth and on the mouth appendages, especially on the palpi. (Fig. 6.) As with the human tribe, the substance to be tasted must be dissolved and the solution must be brought into contact with the special taste buds. Hence

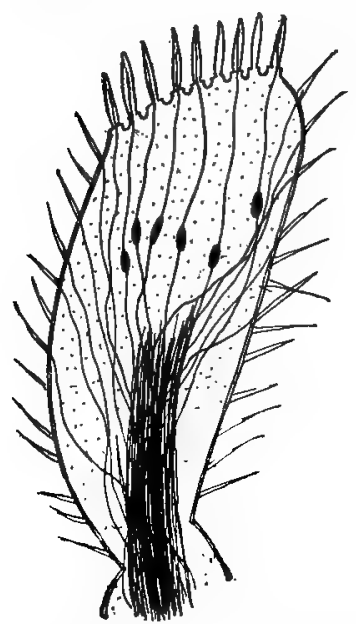

FIG. 6.-Nerve endings in tip of labial palpus of a fish moth. (Kellogg, after vom Rath; greatly magnified.)

it is necessary that the insect shall dissolve its food in the mouth fluids; the taste organs, then, are so situated that they can be brought into the mouth to explore the food or to subject the food to trial before it passes into the mouth. It is not likely, however, that insects are compelled to depend entirely upon the method of trial and error in choosing their food. This would, of course, be true if the insects were confronted with a kind of food entirely new in the life history of their kind; but where an insect has been hatched into the environment in which its ancestors have lived for many generations, it comes into life with inherited tendencies toward foods that have nourished its ancestors, and against foods that its ancestors have found distasteful or harmful, or strange. Perhaps, as with the human family, the sense of taste contributes to the relish or the pleasure incident to the act of eating, and, therefore, to the secretion of the digestive juices. However that may be, the palpi may be observed in active motion during the whole time a 
grasshopper is devouring its grass blade or the potato beetle its wrinkly potato leaf. This may be watched through a reading glass any day you find a leaf-eating insect at its meals.

\section{Hearing.}

That the fifth of our senses is also possessed by many insects is easier to believe than to prove. Anyone who has ever listened to call and response of half a dozen katy-

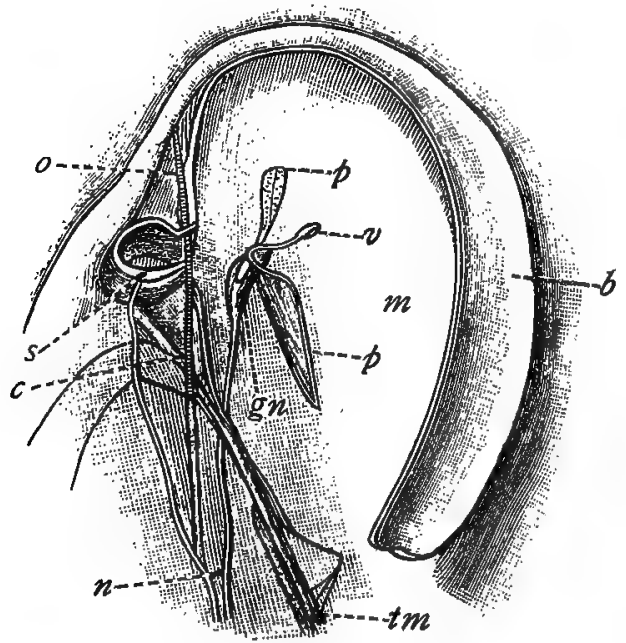

FIG. 7.-Inner aspect of right tympanal sense organ of a grasshopper. Caloptenus italicus. b, chitinous border; $c$, closing muscle of spiracle; $g n$, ganglion; $m$, tympanum; $n$, nerve; $v$, opening muscle of spiracle; $p, p$, processes resting against tympanum; $s$, spiracle; $t m$, tensor muscle of tympanum; $v$, vesicle. (Folsom, after Graber.)

dids, or to two or three cicadas gossiping back and forth on a July afternoon, with their musical "Ah-we-ah-weah-we-ah-we-e-e-e-e-e!" does not lack proof in his own mind that insects hear and make answer to what is heard. 
This may be called negative proof of the power of hearing; but there is also positive proof in the discovery of the pos-

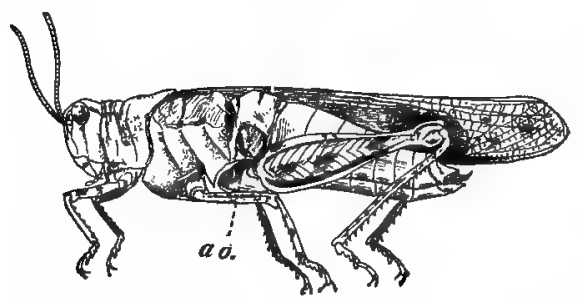

FIG. 8.-Locust from lateral aspect (left wings removed), showing (ao) auditory organ. (Kellogg.)

session of auditory organs by many insects. (Fig. 7.) Our common grasshoppers, katydids, crickets, and mosquitoes have such organs. As with the other senses of insects, we find the organ of this sense in several different parts of the bodies of these simple animals. The higher animals we call higher because of the centralization of related functions; and that centralization has meant the concentration of many formerly distributed senses into one ganglion or knot of our nerve cord-the brain. The low animals, then, are the ones in which these senses are most widely separated as to locality and least differentiated as to kind. This might be said further: the more closely related in point of position these sense organs Child; greatly magnified.) are to the brain, the higher the insect in the scale of life development.

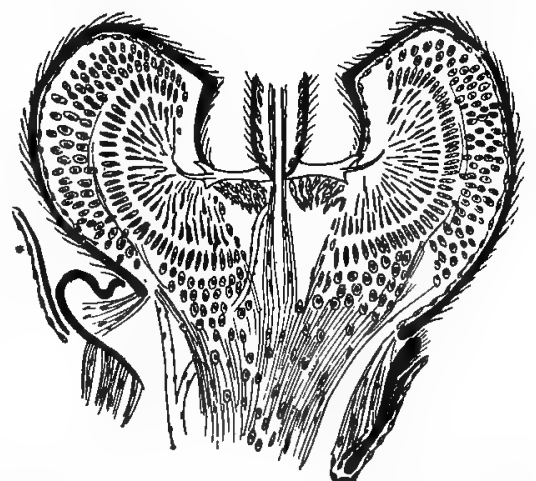

FIG. 9.-Diagram of longitudinal section through first and second antennal segments of a mosquito, male, showing complex auditory organ composed of fine chitinous rods, nerve fibers, and nerve cells. (Kellogg, afier 
The ear of a locust may be found by first killing one of them, and then clipping off the front and the hind wing from one side of the body, when the ear drum may be seen as a thin, white membrane on the first segment of the abdomen. Underneath this membrane or drum is a tiny sack filled with a liquid, and against the inner wall of this sack rests a fine nerve-ending from which a slender
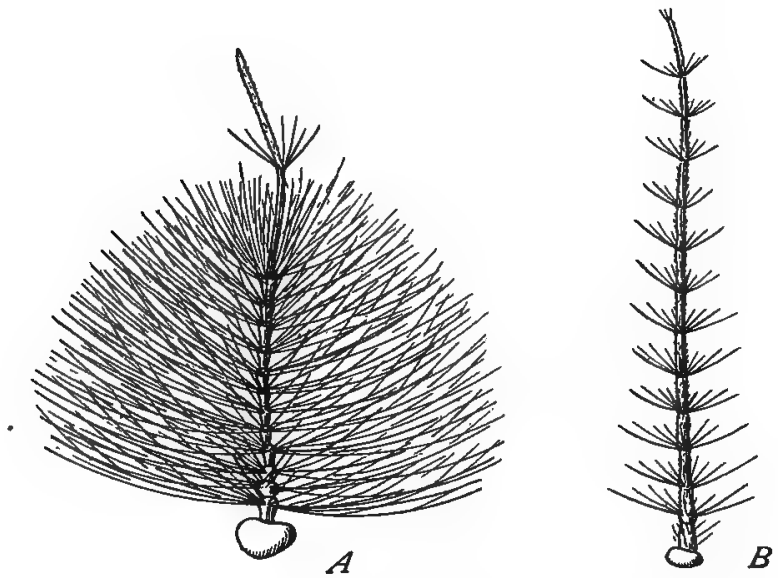

FIG. Io.-Antennæ of mosquito, Culex pipiens. $A$, male; $B$, female. (Folsom.)

conducting fiber runs to the ganglion for that abdominal segment. (Fig. 9.) Mosquitoes hear by means of their antennæ, on which are thickly distributed many fine hairs whose roots lie in a mass of delicate perceiving matter, composed of chitin rods, nerve fibers, and ganglionated nerve cells, and which give to the mosquito the power of perceiving sounds. (Fig. Io.) 


\section{CHAPTER III.}

\section{THE VITAL PROCESSES.}

\section{Respiration.}

In insects, as in all animals, a renewed supply of oxygen is necessary to supply the energy used up in all the forms of bodily activity, as well as to analyze the food into tissue-building products. But insects have no lungs, nor any suggestion of an oxygenating center communicating with a blood center where the oxygenation of the food-laden blood is accomplished. Neither does the air enter the insect's body through an opening in the head. Indeed, the respiratory system of an insect is rather a sack closed at the head end. The respiratory system of an insect is much more complex than that of human beings. It consists of a system of air tubes much resembling the windpipe of a bird, but branching so many times as to become delicate enough to carry the air directly to the finest subdivision of any tissue of the insect's body, going in between the eye elements, driving their load of air inside the wing sacks, in between the leg muscles, even down to the delicate tarsal and antennal segments. It is thought by some histologists that the ultimately fine tracheal tubes may enter a cell itself and oxygenate the protoplasm.

On account of the usual rigidity of the head and the thoracic segments, the respiratory movements can hardly be noticed in these parts of the body of most insects. But the abdominal segments move much more freely 
upon each other, and here the breathing of the insect may easily be studied. Catch a grasshopper, and holding it by the hind legs with the thumb and forefinger notice the alternate contraction and expansion of the abdomen. With the reading glass, look along the sides of the abdomen, and minute openings may be found, usually outlined with some different color. These are the openings, or rather the entrances, of the respiratory system-spiracles-one on either side of the body for each segment of the abdomen. Through these spiracles the balance between carbon dioxid and oxygen must be preserved. Hence, if you wish to kill an insect for your collection box, by means of some poisonous gas, you cannot do it by holding its "nose," but by applying the gas to its abdomen and its thorax, where the openings into its respiratory system are found.

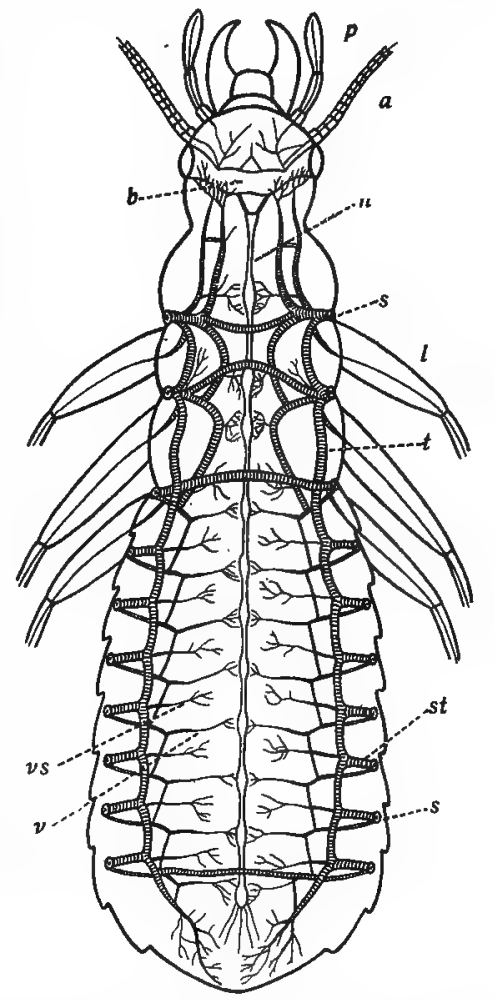

FIG. II.-Tracheal system of an insect. $u$, antenna; $b$, brain; $l$, leg; $n$, nerve cord; $p$, palpus; $s$, spiracle; $s t$, spiracular or stigmatal branch; $t$, main tracheal trunk; $v$, ventral branch; $v s$, visceral branch. (Folsom, after Kolbe.) spiracle, a tracheal tube leads to a main trunk of the system, of which there are two, one along each side of the 
body. From this main trunk there arise in each segment three sets of branches: the branch going upward to supply the muscles of the back and the wings; the visceral branch, running interiorly and supplying the organs of the alimentary tract, the kidneys, and the reproductive organs; and the ventral branch, which carries air to the ventral ganglia, the ventral muscles, and the legs. In

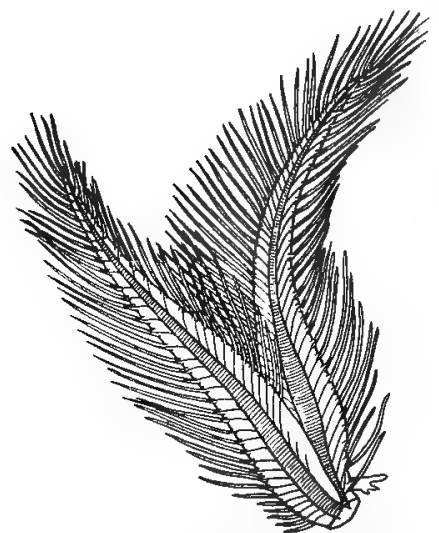

FIG. I2,-Lateral gill from abdomen of a May fly nymph, Hexagenia variabilis. Enlarged. (Folsom.) some insects these spiracles are protected from dust and other foreign substances much as our noses are, by fine hairs; in others a tiny flap of chitin closes the opening; in some others the wing covers bend down over the line of spiracles; but in other insects, as in the order of the bugs, there seems to be no protection whatever.

In insects which are very swift fliers there are, just under the chitin body covering, tracheal pockets, or enlargements of these air conductors; these are supposed to be for the storing of a reserve supply of air which may be drawn upon by the insect during the long, swift flights which use up so much oxygen.

In aquatic insects, or nymphs of insects which later become air breathers, the spiracles are not present at first, and the animal breathes while in the water by means of tracheal gills, developing the spiracular system much later. These gills present to the water an extensive surface with a thin tegument, and under which the tracheæ 
branch to form a network of tubes; through the tegument covering the tracher the gaseous interchange of carbon dioxid for oxygen takes place. The rate of respiration varies with the activity of the insect, with the temperature, and with other bodily conditions. The respiratory movements are mainly reflex, each thoracic and abdominal ganglion acting as a center for the respiratory movements of that particular segment.

\section{Circulation of the Blood.}

In birds and mammals, contact of the blood with the air-that is, the combining of the $\mathrm{C}, \mathrm{H}$, and $\mathrm{O}$ of the fats, the amyloids, and the waste tissue with the oxygen of the air-takes place in a localized region of the body, the lungs, from which the oxygenated blood is sent back to the blood center - the heart - to be driven to all parts of the body. Hence, in these divisions of the animal kingdom, there is a distinct and closed vascular system making a complete double circulation. In insects there is no such vascular system and no definitely prescribed round of the blood in tubes.

Just underneath the chitinized dorsal wall of the insect's body, lies a long pulsating organ having several chambers provided with valves; it is open at both ends and at the sides between the chambers. This may be called the heart, and it does not connect with any network of tubes carrying foul and aerated blood, as in the human animal; but, instead, its pulsations are so performed as to direct the current of blood forward toward the front end of the body, emptying itself in the head, while at the same time the blood then in the posterior end or at the sides is drawn into the long pulsating heart. No air reaches this heart, except such as may remain in 
the blood which is then drawn in, hence the blood must be aerated elsewhere. The respiratory system is made to conform to the needs of this rudimentary vascular system. The tracheæ, penetrating as they do the intramuscular spaces of the body, provide the means for bringing the air into contact with the blood. The blood bathes all the tissues of the body, fills all spaces not filled by the organs, and even bathes the cells of those organs; hence, wherever a trachea empties out its air, the blood there present is oxygenated. The general blood movement is, then, forward through the tissues, till it finally works its way around through the general body spaces and passes backward, following the body contour lines, to re-enter the heart again at its rear or sides.

\section{Alimentation.}

In man, the alimentary canal, beginning at the mouth, is modified into mouth, œesophagus, stomach, small intestine, large intestine, with the familiar three modifications of the last-named, the unassimilated residue finding exit at the anus. In different parts of this long canal are secreted and discharged into the food there present, the various fluids whose function is the reduction of the solid foods taken, to liquid form, suitable for the building of new body cells or the rejuvenation of over-worked cells. This process of reduction is digestion, and the various fluids may be named: as saliva, whose active principle is ptyalin; pepsin, trypsin, pancreatin, steapsin, etc.

In insects the simplest alimentary canal is that of the primitive insects, in which it is merely a nearly straight tube, constricted at either end, and enlarged in the middle into a main digestive cavity with muscular 
walls; this latter corresponds to our stomach. It is separated from the fore and hind portions of the canal by rudimentary valves, which are simple extrusions of the wall of one cavity into the opening of the next cavity, and whose loose edges prevent the return of material. In such insects the food is soft as to its substance and not varied in its nature. Hence there is no need of special glandular extensions of the canal. In insects whose food is of more solid nature or more varied in its character, more modifications of the canal are necessary for the secretion of fluids needed in the digestion of particular portions of the food, and for the retention of the food long enough to let it become

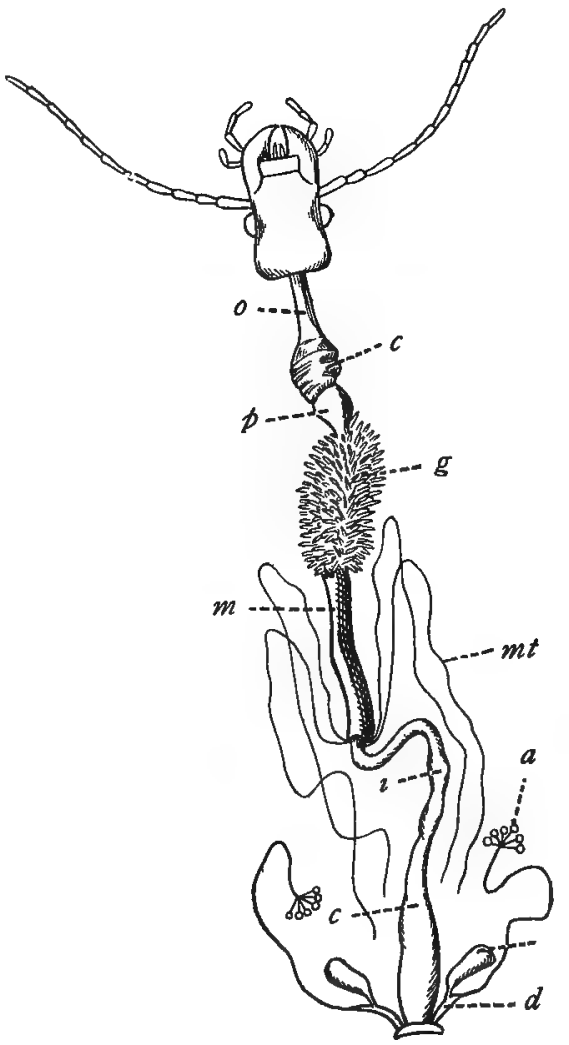

FIG. I3.-Digestive system of a beetle, Carabus. $c$, anal gland; $c$ (of fore gut), crop; $c$ (of hind gut), colon, merging into rectum; $d$, evacuating duct of anal gland; $g$, gastric cæca; $i$, ileum; $m$, mid intestine; $m t$, Malpighian tubes; $c$, esophagus; $p$, proventriculus; $r$, reservoir. (Folsom, after Kolbe.) thoroughly permeated with these fluids. In many insects this is accomplished by the crop and the proventriculus, 
two extensions of the canal between the oesophagus and the stomach. (Fig. I3.)

In the human being the food is mixed with the saliva while it is in the mouth; in the bird, the food is swallowed dry or whole, and this mixing with the saliva is accomplished in the crop. Peptonization is accomplished for birds and for many insects by a second enlargement, which has already been spoken of, just below the crop. In insects, the salivary glands may be restricted to the head and the saliva be discharged from there into the mouth; or the glands may extend backward into the thorax. In connection with the salivary glands, there may be poison glands in such insects as are predatory or carnivorous, and also in spiders.

In the honey bee and the honey ant, also, this crop or fore-stomach serves as a temporary storage cavity for the liquid foods which have been eaten by the bee or the ant, or brought to the nest bee or ant by some foraging bee or ant. The cavity is separated from the true stomach by extruding flaps or outfoldings of its walls into the cavity of the true stomach; and the food swallowed is thus kept indefinitely or let out either forward or backward by the voluntary effort of the insect. Such insects, like some birds, feed their young by regurgitation. Such preparation of the food as part of the alimentation of the parent is evidence of their high position in the scale of life, and of their close relationship to the mammals, the highest of the animal kingdom.

In carnivorous insects this crop is a dilation of the canal axis; but in the Neuroptera and the butterflies, bees, wasps, ants, and the flies, this salivary extension of the canal is a lateral pocket, and serves in all of them for the temporary storage of food just 
swallowed until it can be thoroughly mixed with the digestive fluid.

The stomach of an insect, instead of serving as does our stomach, as a means of separating the solid foods into minute portions as well as mixing them with the pepsin, is more like an intestine; it has not the capacity for strong muscular action, such as has the preventriculus or gizzard. Considerable secretion of digestive fluids takes place here, as well as the absorption of the prepared food mass.

The portion of the canal behind the stomach is, in some insects, modified into regions much like the divisions of the large intestine of the human animal, and named like them, colon, ileum, and rectum. In the primitive insect there are no such divisions apparent; and in many others the colon or first division is absent. In human alimentation the food current, in process of elaboration, is supplied by the mesenteries with the amoboid cells, which play so important a part in the maintenance of the health of the body by devouring the microbes of various diseases. In many insects this function seems to be performed by cells of the lining wall of the stomach, which become free by constriction and float out free in the food current.

The excretory function of the kidneys seems to be discharged by the Malpighian tubes of the insect, which open into the intestine behind the stomach. In the human animal there is no aeration of the food current until, after having been gathered from the capillaries of the stomach and the intestines, from the lacteals, and from the liver, into the right side of the heart, it is sent to the lungs where it is oxygenated, and, being returned to the left side of the heart, it is sent to all the waiting tissues 
of the body. But in insects, so far as investigation has shown, the aerating system of air tubes touches the alimentary canal only at the region where the Malpighian tubes are liberally supplied with trachex. In the human body, waste liberation is accomplished through the lungs (gaseous) and through the kidneys (liquid). In insects, through the aeration of the Malpighian tubes, that is the kidney region, the two sorts of waste liberation may reinforce each other. As to the remaining waste liberation, not accomplished by the Malpighian tubes, the fat body of the insect, lying along the alimentary canal and the dorsal heart, also acts as a waste eliminator, and in some insects acts as a storage tract for the deposit of waste; especially is this true where the insect is a primitive insect and there are no Malpighian tubes. The blood of insects, which is more like the lymphatic fluid of the human animal, contains many fat globules, indicating a connection between this fat body and the circulation of the blood.

\section{Nervous System.}

The nervous system of the larva of an insect, if we select an insect having complete metamorphosis, as a butterfly, is a type of a simple nervous system, one nervous ganglion for each segment of the body, joined by a double cord, and lying in the middle line of the body ventrally. As the adult stage is approached, there is more or less of fusing of these ganglia in all the different orders of insects; but in an adult butterfly the front end of the nerve chain becomes modified into two ganglia, one lying a little forward called the brain or cephalic ganglion, and the other lying a little below the brain and called the subcesophageal ganglion. The brain supplies 
with nerves the simple eyes, the compound eyes, and the antennæ. The subosophageal ganglion sends nerves to the mouth parts, and is itself connected with the brain by a pair of cords between which the œesophagus passes. On back from the subœsophageal ganglion the nerve chain passes into the thorax, where there is one fused ganglion representing several larval segments. This
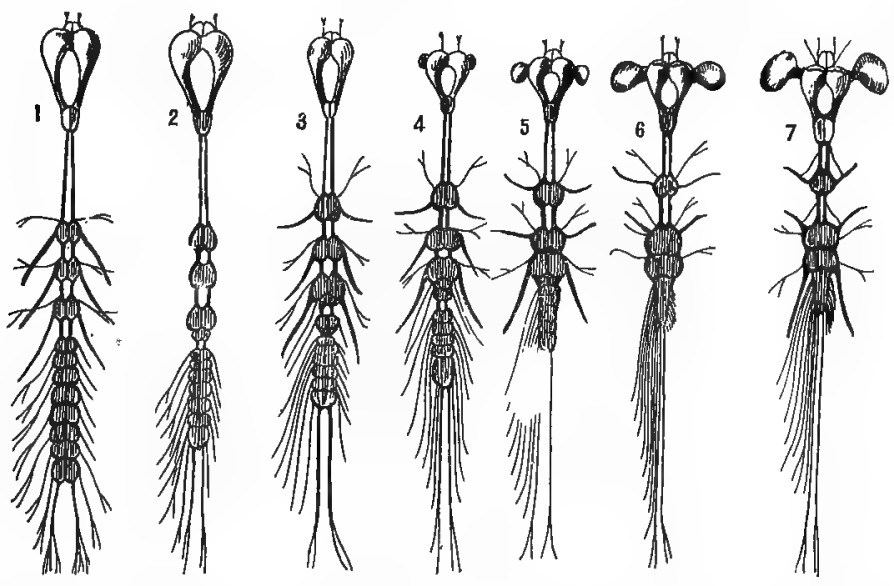

FIG. I4.-Stages in development of nervous system of a water beetle. Ecitius sulcatus; showing ventral nerve cord in earliest larval stage, and, 7 , the system in the adult. (Kellogg, afier Brandt; much enlarged.)

supplies with nerves the wings, the legs, and the many thoracic muscles. In the abdomen there is usually one ganglion for each segment, the nerve chain terminating in several fibrillæ in the last segment. (Fig. I4.)

Lying above the osophagus, and having its origin in front of the brain, there lies the sympathetic system. This, by means of two pairs of ganglia, controls those activities which are safely automatic-respiration, the action of the dorsal heart, and the usual processes of 
alimentation. This sympathetic system connects with the brain in the region of the cords leading to the brain from the subœsophageal ganglion. A central nerve also runs backward in the middle line of the thorax and the abdomen, supplying with nerves mainly the spiracular system, but also sending nerves to the muscles of the abdomen and the thorax to some extent, making their
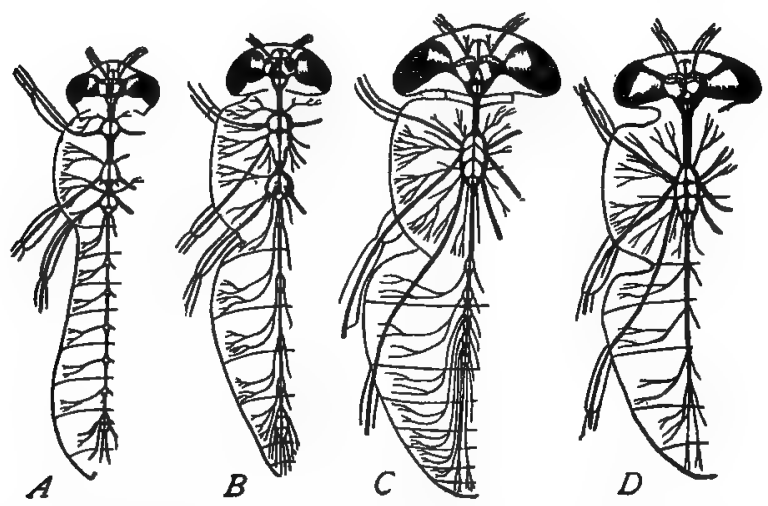

FIG. I5.-Successive stages in the concentration of the central nervous system of Diptera. A, Chironomus; B, Empis; C, Tabanus; D, Sarcophaga. (Folsom, after Brandt.)

movements partly reflex. A grasshopper's head severed from the thorax remains sensitive for some time, and will move when irritated. An insect with its brain removed will eat and digest its food if that food be brought into contact with its mouth parts.

Those insects whose adult nervous system is least differentiated, i.e., consists of one ganglion for each body segment, represent the lowest type of insect life. Fusion of ganglia and centralization of functions, signify advance in nervous perception, and indicate higher types of insect 
life. Thus the adult butterfly is more highly organized nervously than it was in the caterpillar stage. (Fig. 15 .) Similarly, the bees and the flies, with their fused ganglia in the three regions of the body and the attendant centralization of functions in those fused ganglia, are to be reckoned as more highly organized living beings than are the locusts with their much more nearly similar and segmentally arranged ganglia. Examination of a series of animals from the simple toward the complex shows one other fact of nervous organization. The upward series shows a tendency not only toward this fusion of ganglia and centralization of functions, but also to place the emphasis upon the cephalic ganglion, centralizing in it the perception of stimuli which, lower in the series, were either distributed to other parts of the body for interpretation, or were not differentiated from each other; as hearing, tasting, and the contact sense. 


\section{CHAPTER IV.}

\section{DEVELOPMENT AND METAMORPHOSIS.}

Every animal develops from a single cell; and, when that cell is enclosed in some characteristic wall or covering, is accompanied by more or less of reserve food or yolk, and undergoes a resting period of greater or less length, we call the cell an egg. That insects come from eggs is almost as familiar a fact as the insects themselves. But the average student of nature usually stops there, and knows little or nothing of the changes undergone by the grasshopper, the butterfly, or the firefly before the adult insect appears. Many of us have found grubs without knowing that they are a stage in the life of some beetle. The various cocoons found hanging to some twig or weed or tree are interesting, without impressing us as only one stage in the life of some gay butterfly or somber moth. Worms are "just worms" for most of us, nasty horrid things that do nothing but eat up our flowers or gardens or trees; yet even the worst one among them will disappear from our sight, and if we had the desire we could trace it to its winter quarters, mark the place, and the next spring we should be rewarded by a flutter of bright wings and a decided preference for flower nectar in the new animal coming out from the cocoon, all its days of leafeating forgotten, neither knowing nor caring for anything save sunshine, pollen, and nectar.

Insects, then, come from eggs, and the changes of form undergone on the way from the egg to the adult 
or mature insect are to be expressed in one termmetamorphosis.

\section{Development with no Metamorphosis.}

If an insect undergoes no bodily changes after hatching from the egg, there is no metamorphosis. This is true for only a very few insects, as the thrips and the fish moths. These insects, when they hatch from the eggs: look exactly like their parents except that they are smaller. And they come to maturity by a series of moults after each one of which the body is larger; no new organs appear, there is simply an increase in bulk until the size of the parent is reached, then the moults stop.

\section{Complete Metamorphosis.}

But for other insects than those mentioned, changes take place during the period of immaturity, changes involving body form or life habits and conditions, or both. The changes may affect only slightly the body form, the life habits and conditions remaining practically unchanged we speak of this mode of reaching maturity as incomplete metamorphosis. Where these changes include not only changes in body form, but also in the life conditions and habits, this series of changes we call complete metamorphosis; it comprises the four stages of egg, larva, pupa and adult.

Besides these three modes of attaining maturity a few insects, one family of beetles, the blister beetles scale insects, and a few parasitic hymenopters, multiply the larval stage several times; the blister beetles at thei: different moults appearing with markedly different larva bodies, but the last one finally merging into the familiat resting pupa of its kind. (Fig. I6.) This last mode i: 
called hypermetamorphosis. All insects may be divided along the line of complete or incomplete metamorphosis; those with the additional larval stages being placed with the complete and those without change of body form during immaturity being placed with the incomplete.
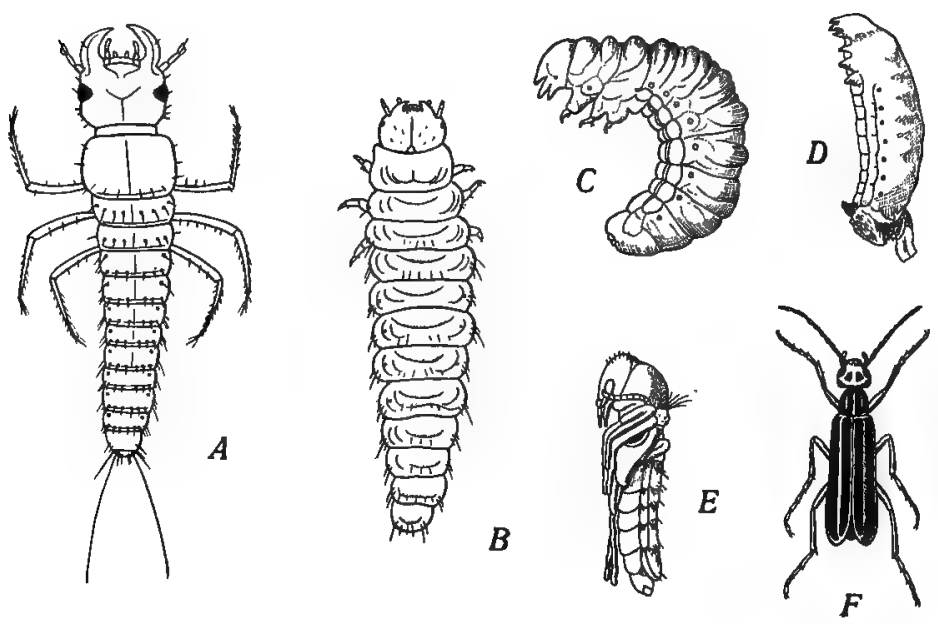

FIG. I6.-Stages in the hypermetamorphosis of Epicauta. A, triungulir; $B$, carabidoid stage of second larva; $C$, ultimate stage of second larva; $D$, coarctate larva; $E$, pupa; $F$, imago. $E$ is species cinerea; the others are vittata. All enlarged except $F$. (Folsom, after Riley, from Trans. St. Louis Acad. Science.)

The insects with complete metamorphosis are, perhaps, the most familiar insects. Take, for example, the tomato worm. (Fig. I 7.) The eggs are at first green like the tomato leaf upon which they were laid; in the course of three or four days they turn yellow, and in about six days they begin hatching. The eggs are laid singly and are to be looked for on the under side of tomato leaves. The larvæ also feed on other plants, as the Texas thistle, but the author has never found eggs on the thistle. From 
these eggs hatch tiny green caterpillars less than a quarter of an inch long; these begin eating the tender tomato leaves, moult four times, and grow to a size of about four inches. At the caudal end of the abdomen there is a blackishgreen or bluish-black horn pointing backward; and along each side is a row of yellowish stripes placed obliquely. During the three weeks of the larval life these cater-

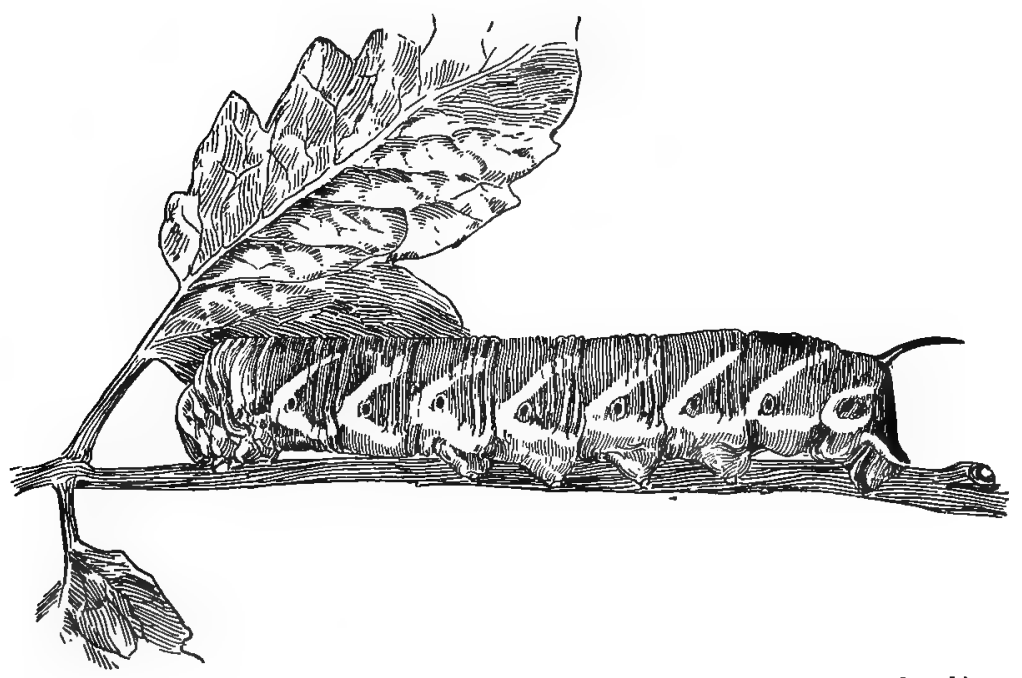

FIG. I7.-Larva of tomato worm. (Kellogg, after Soule; somewhat reduced.)

pillars eat enormous quantities of leaves, and they seem especially to enjoy finding a tomato-green or ripe, it does not matter; of course this means more to eat and less work to get it. At the end of this time they stop eating and burrow into the ground at the base of the plants which they have been eating, and lie inactive. If the poor caterpillar is in a pan in the schoolroom and cannot make you understand what it needs, it will crawl 
hurriedly around the pan, attracting as much attention. and looking as ferocious as possible, and will then "turn up its toes" in disgust at your lack of understanding. Its period of inactivity in either place will be about two weeks, during which the body shortens and becomes larger around, and begins to look dried. At the end of this time, if you are on hand when the wonder happens, you will see the old skin crack along the back for the last time, while the new body works itself loose from the old caterpillar skin. This new animal is to be called a pupa. (Fig. I8.) It has

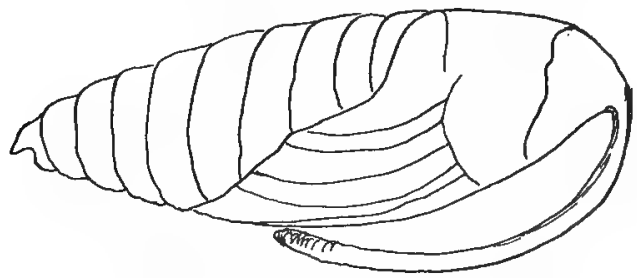

Fig. i8.-Pupa of tomato worm.

a large head end and a gradually tapering abdominal portion. The wing areas gradually become visible, with the suggestion that the new wings are folded around the body toward the under side. From the head end there extends along the front of the pupal body an odd appendage looking much like a jug-handle; this is the case for the long sucking proboscis. One such transformation as this observed by the author, began at noon and was over by two o'clock. The characteristic mahogany brown of the pupa case did not appear till later.

The next spring, when the ground warms up and you go at the right time to the place where your pupa went under, you will see this pupa case, grown old, crack at the big head end and down a little on the back, and 
out will come the head of a gray moth. Gradually it works its wings out, then its front legs; then, by pushing back on the old case with its front legs, it works out the other pairs of legs and afterward its abdomen. It rests frequently while it is doing all this, and now it rests a longer time than it has before. Then it braces itself and begins pulling its proboscis out of the jug-handle sheath. This emergence may last an hour and a half or two hours.

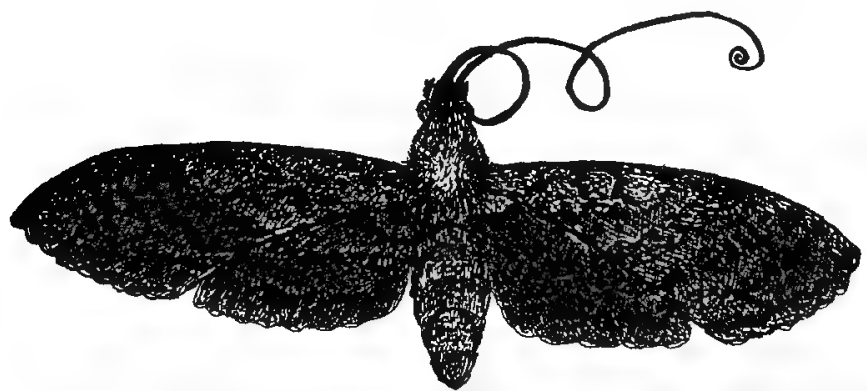

FIG. I9.-Adult of tomato worm, showing sucking proboscis uncoiled.

The body wall must harden to form a secure attachment for the muscles which are concerned in the violent exertion necessary to free the insect from its hard, dry pupal case. (Fig. I9.) This moth represents the completion of the life cycle; it is the parent repeated, the adult again: It hangs to the old pupal case-the only familiar thing in a world of strangeness-occasionally waving its wet, wrinkled wings. Gradually the body wall hardens, the wings straighten out and dry, the different colors of the scales and hairs on its wings and body appear, and probably, by the following morning, the splendid gray-winged moth will be flitting from flower to flower on the trumpet creeper or in the petunia bed, not needing to be taught where to look for its breakfast, having knowledge of how 
to take care of itself, provide for itself, and look after the wise placing of its eggs in the future, if it is a female moth. The internal changes are also great. The musculation of the caterpillar is that of a worm, for crawling, wriggling, worm-like locomotion, and instead of long muscles we find many short muscles running lengthwise of the body, while other muscles run around the body at nearly right. angles with these. In the adult the muscular needs are very different, where, especially in the thorax and the head, many strong cross muscles must provide for flying, running, and eating. The alimentary canal of the larva is adapted for disposing of solid food, while in the adult stage the alimentary canal is adapted for sucking liquid food from flowers.

Not only are there changes such as have just been described for the butterflies and the moths, but the respiratory systems of some insects must also change. The dragon-fly nymphs are adapted for living in the water, while the adult dragon flies are air-breathing insects. The heart and the nervous system of an insect with complete metamorphosis, show lesser differences, but even here there must be changes on the way to adulthood. The ventral nerve chain of the larvæ of some insects contains twice as many ganglia as does that of the adult; the cephalic ganglion enlarges on the way toward the mature insect, and the front part of the larval heart gradually narrows at the head end into what may be called, in some insects, the aorta.

In the pupal stage the insect is defenseless; it can neither fight nor run away; hence its safety lies in concealment in some burrow, or in the sagacity with which its larva spun a cocoon and hung itself up where it would not show, or where it would so harmonize with its sur- 
roundings that it might be visible but not distinguishable. The insect in its pupal stage does not eat, but the larva has provided for this by eating greedily all through its larval existence; so there is a large supply of surplus food within the larval body when the pupa begins the wonderful changes toward adult form. Upon this reserve the pupa draws until the time of its emergence as an adult. Although the pupal insect does not eat, nor, except in a very few cases, move about from place to place, we are not to regard it as quietly doing nothing while it is in its burrow or cocoon. Really this is the period of the most wonderful changes in all the insect's life. Gradually there comes about, in the case of the tomato worm, for instance, the replacement of the solid food digesting apparatus, with the alimentary organs necessary for digesting liquid food; the caterpillar set of muscles must be replaced by the wing and the leg locomotor muscles; the wings themselves must be developed; the wonderful compound eyes must be built, facet by facet, with the marvelous structure behind each. Embryologists tell us that this building up of new organs is preceded by a breaking up of most of the internal organs into a general body fiuid, out of which rich food supply, the new organs, internal and external, must be built, with perhaps certain bud cells as centers for the new growths.

All young animals, even the one-celled, have a longer or shorter period of immaturity. In the cases where the young of insects are born alive we must conceive these changes as having taken place before the young were freed from the egg duct of the mother insect, as is the case with such of our flies as do not "lay eggs." In complete metamorphosis the insect is born youngest, is most immature, and appears in the form farthest 
removed from the parent form. In the case of the ametamorphic insects, we may speak of the young as undergoing some such maturing as do the young ot somewhat higher animals, development without metamorphosis; while the incomplete metamorphosis sorts represent a type between ametamorphic and complete metamorphic.

\section{Incomplete Metamorphosis.}

As an example of incomplete metamorphosis, we may take the box elder bug that is becoming such a pest wherever box elder trees are grown. Probably these trees have much to do with the appearance of the bug. All animals, even in the human tribe, follow their food around the world; or else, if they have the power of initiative, as human beings do, they take their foods along to the new place of abode. From the egg there hatches a tiny red bug, soft-bodied, and without wings, yet enough like its parents to have the same mouth parts and the same feeding habits. These small bugs feed, so far as we know, on the sap of the young, tender stems and twigs. They seem not to be confined to box elder trees, though probably feeding there more often than elsewhere. To accommodate the increasing bulk, the bug sheds its old skin frequently. The body wall becomes hardened by chitin, and will not yield as the insect continually grows; hence it is split open and the insect casts it off; but before this happens the insect has made itself a new skin inside the old one, and when it emerges, the new wet, wrinkled skin stretches and so makes room for the insect grown larger. The wings are represented, at first, by bud cells under the skin, but gradually these grow until the rudiments of wings appear beyond the body wall in the shape of wing pads. The body continues to 
increase in size, the wing pads develop into wings, the adult colorings of black and red appear until, when adult size is reached, we see a familiar box elder bug with its red " $\mathrm{X}$ " on its black back, its gauzy under wings for flying, and its slender legs to carry it efficiently about into more places than we wish it could get into.

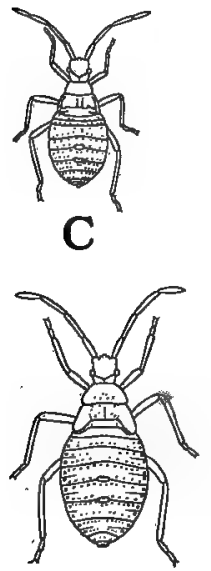

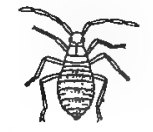

B
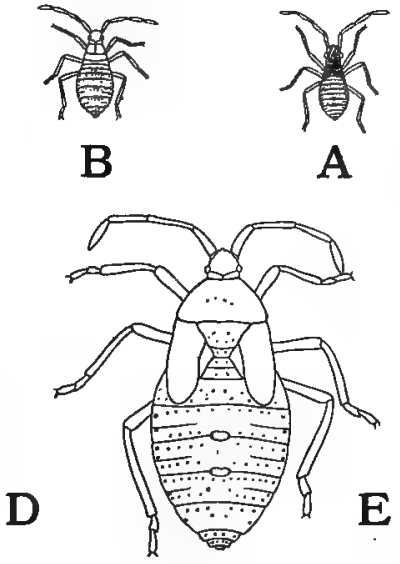

A

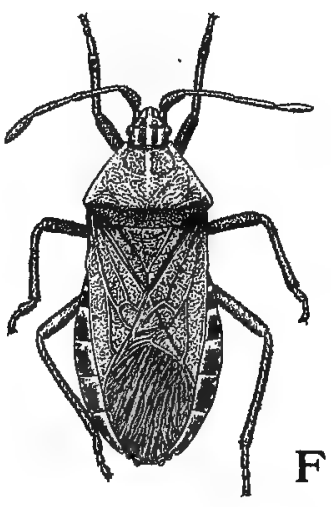

FIG. 20-Six successive instars of the squash bug, Anasa tristis. $\times 2$. (Folsom.)

In this form of metamorphosis there seem to be but two intermediate stages, the egg and the larval stage, the latter greatly extended. (Fig. 20.) Where the insect has complete metamorphosis, the food habits of the adult generally differ from those of the larva; but where the insect comes to adult form by incomplete metamorphosis, the young usually has the same food preferences as it will have later in life and as its parents had before it. 


\section{CHAPTER V.}

\section{INSECTS AND THEIR CLASSIFICATION.}

Entomology, or the study of insects, had its origin far back in the days when scientists were generalizers and had not yet become specialists, each in his particular realm. Linnæus, Carl von Linnè, so often called the father of modern botany, was one of these general scientists. The field covered by this one man included minerals, animals, and plants, any one of which is more than enough for one man nowadays. Nevertheless, the thoroughness of his work in insects is evidenced by the fact. that his seven orders of insects remained a satisfactory system of classification for more than half a century. Classification is, of course, not the most important thing about an animal or a plant, nor is it in any sense a finality in the study of the living being. When one has the name for a living being, he has a handle for using the tool of this new information in working out more valuable conclusions. The economic relations of that living being with other animals, with plants, or with man, are more important. Comparison of the structure of the lower animals with the higher is valuable. To estimate how closely a bee approximates a man's sense of sight, or transcends man's ability to smell keenly, to recognize his kind, and to find his home without road, compass, chart, or beaten track, all these are much more valuable than to know that this particular bee rejoices in the name of Apis mellifica. Yet, where there are thou- 
sands of insects and not all of a kind, one must have some way of knowing what each insect is before he can begin to work out all the marvelous relationships between that insect and others much like it or differing much from it. Besides these facts, which still are of secondary value, the student of insects will come to know that of all the different sorts of insects some are low, while some are high in the life scale; some are simple in structure, while. others are very complex; some have more intelligence than others; some have higher nervous organization than others, with sense powers that eclipse man's powers, with instincts whose like we do not know, or if we did once know them in the days when man was first learning his new world, they are now covered over completely, buried beneath the later stratum of reasoning as the basis of: activity, the determinant of action. In short, life is a continuous stream with powers fundamentally the same, whether that life is manifested in this body or that; and each race or tribe of beings exhibits unmistakable relationships to the beings above and below it, those relationships being stated in terms of structure, or metamorphosis, or nervous organization.

Insects, as classified by Linnæus, were all included in seven orders: Hymenoptera, Diptera, Coleoptera, Aptera, Lepidoptera, Neuroptera, and Hemiptera. Under his Hemiptera were included the insects now forming the Orthoptera. The Neuroptera included a mixture of very dissimilar insects now set apart in three different orders. Rearrangement of the remaining insects on the bases of structure and metamorphosis, and the necessity of providing a place in the general scheme for the many insects that Linnaeus never saw, and which later naturalists have been continually finding, has led to the formation 
of other orders which express the new lines of division and discovery.

The simplest insects are wingless, have little differentiation of body form, and no free metamorphosis. These are the Thysanura. The fish moth is an example of the order and probably the member most frequently seena wingless, swift-moving little creature with six legs. It is often found among musty piles of paper or among folds of clothing laid away. The Isoptera, or termites, have a growth instead of metamorphosis, and only the kings and queens of the colonies are winged. These insects are sometimes called white ants. The Corrodentia, or book louse order, is represented by the pale-colored, flattish little creatures that hustle out of sight when you open an old book long unused and a little musty. Some of the Corrodentia are winged and all have incomplete metamorphosis. The Mallophaga include the sheep and the goat lice, and the bird lice. They have biting mouth parts and eat wool, hair, or feathers, while the true lice feed upon blood which they suck from the victim's body. The Euplexoptera, or earwigs, resemble some of the rove beetles, but may be distinguished by the fact that they have a pair of forceps-like appendages at the caudal end of the body. They have four wings and reproduce by incomplete metamorphosis. They do not creep into people's ears, as the old notion had it, but usually are predaceous, feeding, according to Howard, upon dead insects, snails, and small living insects. 'The Physopoda, or thrips, are mostly flower pests, though some of them eat other insects. Sometimes, close down to a head of red clover, you may see some small black insects which try to frighten you off by thrusting the end of the abdomen energetically up into the air. And if you are looking 
through a microscope this may appear a trifle ferocious. They are winged, probably suck their food, and have incomplete metamorphosis. The Mecoptera is the order of the scorpion flies, so called because some of the order have the anal end of the abdomen shaped like the sting of a scorpion. The mouth parts are beak-like, but with mandibles at the end of the beak. The insects have four wings and reproduce by complete metamorphosis.

The Trichoptera have hairy wings, four of them, and they use them only in the adult stage. They are called caddice or caddis flies. The larvæ, or caddis worms, are highly prized as bait by old fishermen in England. These queer larvæ make a case of sticks, sand, or straw about themselves, then stick out the head and the thorax, and go crawling about in the water for food. The adults look considerably like small moths. 


\section{CHAPTER VI.}

\section{GENERAL SUGGESTIONS FOR FIELD WORK ON INSECTS.}

The teacher who hopes to present the subject of insect study must be a leader in doing things, not simply a director, expecting to give directions and have them obeyed. The beginner learns to do things by seeing some one who knows how, go ahead. Not only this, but the instructor needs to be with the pupil to show him where to go, what to get, and when to stop. And in securing insects, it is quite as valuable to know when to stop as to know when to begin. There are many valuable insects which deserve protection, and which the beginner can learn only gradually to recognize and to spare when looking for new insects. The real object of the study is to learn the life habits, the individual peculiarities, and the relationships of these insects to each other and to ourselves; and the only way to do this is to find them in their places of abode and observe what they are doing and how they get along in the world. Or, if a beneficial insect is desired for extended study, bring along with it plenty of its natural food to keep it going while its appearance and conduct are being studied.

In beginning the work, it is an effective thing to organize, say, four expeditions, one to some wood pile, one to the open fields in the middle of the day, one to a pond, and one to some electric light globe, or, failing in this latter, a kitchen window may be raised and the screen 
opened while the investigator "waits for a bite." In the excursion which leads anywhere near trees, be on the lookout for cocoons hung on leaves or twigs. Cut these off and bring them home. In the garden there may be caterpillars, and what they are eating should be noticed, so as to bring in for study the caterpillar and its food also.

The work fails of part of its mission if it does not teach lessons of humanity. All insects, even the injurious ones, should be killed as quickly as possible; there is never any excuse for taking life-lightly or with unnecessary cruelty. Life is a thing of like powers, whether it is bound up in the body of a grasshopper, a butterfly, or a human being; all are God's creatures, and all deserve consideration at the hands of God's highest creatures, men and women, girls and boys.

The work may be made clearer and more likely to be remembered if it is made to emphasize at first the common orders of insects, so that the element of familiarity may be used to build the unfamiliar upon. Each insect selected should be a typical insect of its kind, the better to illustrate the physical differences. The bug should be as big a bug as possible. The beetle should be a big fellow and have hard, horny wing covers. The fly ought to be a horse fly, if possible, as the house fly is small. No exceptional forms, nor forms of doubtful structure which cannot be located with certainty, should be chosen for study; they will come all right after a while, never fear; they are to be found everywhere, along with the insects that are well known! One of the preliminaries is to get together enough knowledge of the different orders to know representative forms of them when they are seen. Hence the physical appearance of each should be studied so as to know the mandibles of beetles and 
their hard wing covers; the mandibles of grasshoppers and their soft, straight wing covers; the beak of bugs; the coiled proboscis of butterflies and moths; the four membranous wings and hairy, or smooth and pedunculate bodies of the bees, ants, and wasps; the two wings of the flies; and so on, if other orders are commonly represented in the neighborhood where the work is done.

In the late summer one ought to. be able to find butterfly and moth larvæ, or larvæ that have already spun their cocoons and have turned into pupæ. If the former, bring them into the school-room along with food enough to last them; and if the latter, bring in the twig or stem on which the pupæe are hung, or the dirt in which they were found, and put them into a safe place, where, later the students may have the privilege of seeing what metamorphosis means. There is nothing that quite takes the place of seeing the thing for yourself in the big world of Nature's wonders. Many other things will suggest themselves to the earnest instructor who is on the lookout to open up the world of knowledge to the young mind. The child will often be the leader as to where you are to go and what you are to teach him. My best teachers have been my students who have asked me things that I did not know. Never forget that you are a child yourself, and that it is still your privilege to learn truth along with them from the great Master of Truth Himself. The bookworm side of study is not to be emphasized; leave that for him who cannot do the thing in any other way. There is such a world of things that are very much alive, that one cannot afford to waste the time over book knowledge of living creatures. Just give the creatures about us a chance and they will teach us many a lesson in humanity and gentleness, ingenuity and 
device, successfulness and joy of living, such as will often put us to shame.

As to the apparatus necessary in the work, there ought not to be so much of it that all the student's power of initiative is taken away from him. The chance to acquire the power to deal successfully with one's surroundings is the birth-right of every human being; if we teachers prepare the way too much, we rob the child of this birth-right.

Most insects run away if they are pursued, and some of them have a very long jump; so it is necessary

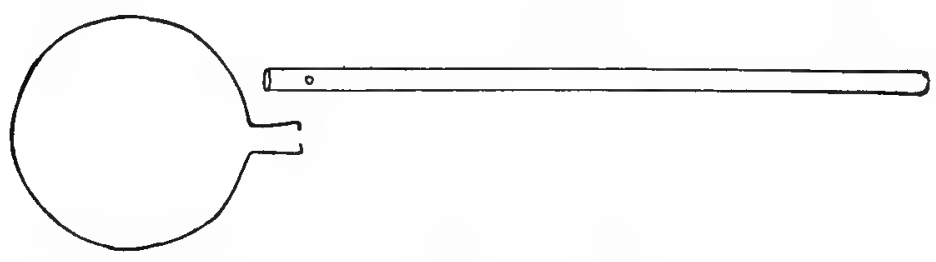

FIG. 2I.-Diagram of insect net.

to have some means of lengthening one's own jump to keep up with them. A good insect net is made by bending a piece of stout wire in the form of a circle, with about five inches of both ends of the loop bent parallel downward, so that the loop may be fastened to a handle, preferably a round handle. This stick should be about five feet long, and should have a hole bored in each side about five inches down from one end; and the parallel ends of the wire loop should be bent into these holes, and then fastened firmly to the stick by a binding of flexible wire. This forms a frame-work for the net. (Fig. 2r.)

A piece of mosquito bar or coarse net is used for the net. The piece should be long enough to sew around the wire loop; and the bag should be about twice as deep as 
the diameter of the loop. The bag may be left square at the bottom, or may be cut pointed or rounded. Armed with this, one is usually able to lengthen his jump so as to keep up with even the grasshoppers.

For aquatic insects, another sort of net may be more useful. The wire loop and the long handle will be necessary, unless there can be mustered a pair of rubber boots; but the loop should be considerably smaller, not over eight or ten inches across; this net is to be used in water,

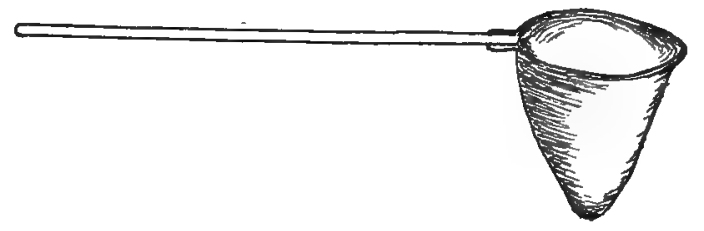

FIG. 22.-Diagram of dip net.

not in air, so it must be stouter. A piece of coarse, stiff net should be cut into circular form about six or eight inches larger in diameter than the wire loop. Turn in the edge and sew it firmly to the loop, preferably with cord. This makes a round-bottomed net, which remains spread out whether wet or dry. (Fig. 22.)

Another valuable help for all field work is a common reading glass. One costing about $\$ \mathrm{I} .75$ or $\$ 2.00$ is powerful enough. It enables half a dozen people to see a given thing at one time, and also serves to watch insects which are eating, showing how they do it. It is held at ordinary reading distance. It may be held over a bee while she is on a dandelion or a milkweed cluster; even a wasp will not resent your looking at her with this magnifier, touchy as wasps are; and butterflies reveal many 
secrets through its round disk. A hand lens magnifying about fifty diameters is highly useful for the smaller insects.

Another requisite, which is used for disposing of noxious insects, and such others as may really be needed for examination, is a killing bottle, or other means of killing your insects. Beneficial insects should not be killed; but all noxious insects should be killed. To avoid making any mistakes, all insects should be taken alive and studied in that condition; then the advice of the instructor is to be followed as to whether to kill your "find" or not. Every living creature has its mission, and the day has gone by when we can afford to destroy beneficial animals of any kind; and you will attain one of the most valuable results in field zoology if you learn which are our familiar, beneficial insects and which are the harmful ones.

Having the knowledge that some of your insects will deserve killing, it will be necessary to have a small bottle of gasoline for use in killing the grasshoppers, the katydids, and the locusts. These are big coarse insects, are not beneficial, and their bodies are not delicate enough to be harmed by the action of the gasoline. The fumes of the killing bottle do not readily affect them; they suffer long, and sometimes come to life on the pin after you are reasonably sure that they are dead; and there is never any excuse for causing needless suffering. The animal with a highly organized nervous system dies quickly; we often hear of "instantaneous death" with respect to such animals. But animals of less complexity are not so quickly affected, hence die more slowly. The grasshoppers all die more slowly than do the flies, the bees, or the butterflies. 
For the more nervously organized insects, one must have another mode of killing them. A wide-mouthed glass bottle with a tightly fitting stopper-a small candy jar with its ground glass stopper is excellent-should be fitted with a wad of absorbent cotton in the lid. The jar should be wide enough to admit large moths and butterflies and flies without doubling up their wings. Just before putting in the insects that must be killed, for instance, saw flies, horn tails, mosquitoes, stable flies, drop a few drops of ether or chloroform on the absorbent cotton in the lid. Close the jar quickly and tightly. This jar may be used for killing flies, but the advice of your instructor must be followed as to which flies are to be killed. It would never do to kill the valuable Tachinas, or the syrphid flies; while mosquitoes, house flies, stable flies, and hessian flies are to be killed without mercy.

The killing bottle will do for the stronger dragon flies also, but not more than one specimen for the whole class should be killed, and when you put it into the jar, you must put considerably more ether on the absorbent cotton. If you reach the study of dragon flies late in the summer or early in the fall, you may find quite a number of dragon flies that have died a natural death. These will do quite well for examination. Care should be taken not to put many insects into the killing bottle at one time; if the insects are moths or butterflies, and large, only one or two at a time. In bringing home your finds, the natural food inclinations of your insects must be regarded. The shepherd would not be so foolish as to shut up the wolves with his sheep. For instance, if you catch some spiders, better give them a box by themselves, few in the box, and not long at a time; or you will be likely to have nothing left except some unusually well-fed, big spiders. So 
along with you to the collecting field should go several small boxes rather than one big box. Remember, your first object is to bring home your insects alive to find out about them, and whether to kill them or not. A cyanid bottle may also be used for one of the killing bottles; but extreme care must be observed in the use of it, as the cyanid is a deadly poison, and the bottle must be kept always corked; it would much better always be left at school, and the safer chloroform or ether bottle taken to the field. When one has become something of an expert in hunting and trapping insects the cyanid bottle becomes a safer companion on the various expeditions.

If the instructor decides that it may be used, it may be made in this way. A wide-mouthed bottle should be chosen, and into it may be dropped some small lumps of potassium cyanid. As long as this substance is kept dry it does little harm and may be safely handled with the hands dry. Then on this is to be dropped a small quantity of powdered plaster of Paris, also dry, enough to fill the spaces lightly between the cyanid lumps. Then mix up a small quantity of plaster of Paris in water, enough to cover the dust and limp mixture about an eighth of an inch deep, using enough water to have it spread easily. Run this in on to the mixture, doing it as quickly as possible and taking care to leave a small opening. somewhere through which you may at the very last pour in a wee bit of weak sulphuric acid on to the cyanid lumps which may be there, afterward quickly covering this opening with the wet plaster also. Take care to do all this in an open room with the windows open; then there will be no danger. This makes the most effective killing bottle for the generality of insects; and if used rightly, with due caution, and always kept tightly corked it will be found satisfactory. 
After the wet plaster of Paris has been run in so as to cover the mixture completely, leave the bottle in the open air for two hours or less according to the dryness and heat of the outer air; it will then be sufficiently dry, and after that must be kept carefully corked except when putting in your finds that are to be killed.

The usual reservations must be made in the use of this bottle; no beneficial insects are to find their way into it unless it is past their season of usefulness; small and large insects must not be put into it together, as their struggles are apt to injure the smaller, weaker ones; and insects put into this killing bottle must not be left too long without attention. This same precaution should be observed with respect to the chloroform killing bottle; there is a tendency with some insects, for the muscles to stiffen if they are left two hours or such a matter in the fumes of chloroform. There seems not to be this fault with the ether. When the cyanid bottle is opened it should be in an open room; and the killing bottle should not be left habitually in one's sleeping-room. This last precaution is given because it is often advisable for each student to have a killing bottle of whichever kind the instructor may deem the best.

The wings of butterflies and grasshoppers are part of the requisites for finding out what kinds of butterflies and grasshoppers you have; hence it is necessary to set them up in such a way that their wings show well. A drying board is useful in this case. Take two small pieces of inch lumber, eight inches long by four inches wide. Saw a V-shaped piece out of the long side of each of these two pieces, with a slope of the sides at an angle of $25^{\circ}$ to the edge of the piece of lumber. Do not make the $\mathrm{V}$ too sloping; this angle determines the angle of the 
spread wings; some collectors prefer to spread them horizontally. Nail a narrow, thin strip on these two sloping sides so as to leave an open space between. After you have these pieces together, turn the board under side upward, and, with small tacks, fasten a strip of corrugated paper, or strips of corn pith all along this opening between the thin board strips. This makes a groove in which the insect's body is to rest while the wings

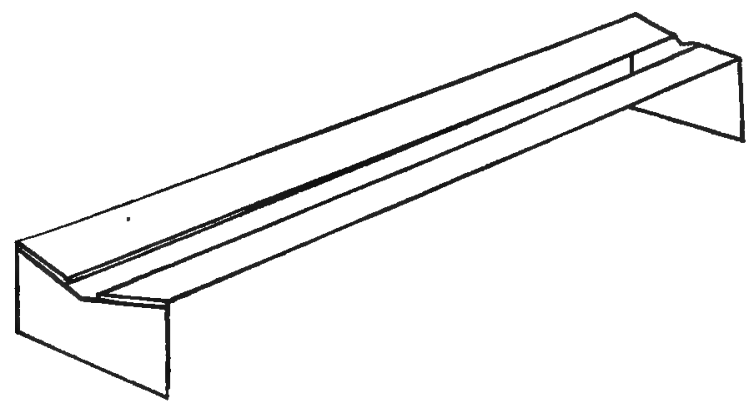

Fig. 23.-Drying board.

are drying and the wing joints hardening. If the class is large, it will be best to make several drying boards, some of them with the groove wide to accommodate large insects, and some others for the smaller insects. (Fig. 23.)

A collection box would best be made by a cabinet maker, and may belong to the class or the school, or to the individual student. It should be made with joints as tight as possible, and with a glass cover. Several patterns will suggest themselves, but the best ones are the boxes that will close most nearly air-tight. Smaller insects will be almost sure to lay their eggs on the insects that you have carefully dried and identified, and when their eggs hatch out, the greedy grubs will eat up the whole lot, beginning with your finest specimen usually. Naphtha 
balls ought to be kept in your collection boxes. They may be pinned inside a bit of mosquito bar, or a hot pin may be thrust through the balls and then they can be pinned in the corner of the box. For temporary boxes, cigar boxes will do very well, and they will keep the insects for a considerable time if this naphtha precaution is taken.

The tickets for your specimens need not be large nor contain much of data. Several manuals may be used by the class in identification; hence the labels should state the authority for the name. Abbreviations for the names of the authorities may be agreed upon, and these abbreviations used on the labels or tickets. The page cited is also valuable in case of doubtful classification. The locality, the year, and the month of finding are sometimes used on such labels, and are useful information concerning the time of the appearance of the insects in given regions, and as to the character of the insects found in any given region. The common name may be the one used on the ticket, if the authority recognizes a common name.

The facts that may be learned from a study of living beings are really a revelation of the Creator's way of working out these things in his universe, of which you and $I$ are a part. And as the study grows upon the student he will probably take one of two attitudes: wonder that he is so small a part of the life kingdom, or the marvel that so defenseless an aninal, a creature so frail physically as man, does stand at the head of the myriads of animals to be found in air, on sea, and on land. "Reverence is vital to morality; and whatever quickens within us the feeling of dependence on a higher power, whatever leads us devoutly to admire the order, beauty, or mystery of the universe," is good for the individual well-being of man, the highest of God's created beings. 


\section{ORDERS OF INSECTS.}

Coleoptera-(Sheath wings), Beetles.

Orthoptera-(Straight wings), Grasshoppers, Crickets, Cockroaches.

Hemiptera, Bugs.

Lepidoptera-(Scaly wings), Moths and Butterflies.

Hymenoptera-(Membrane wings), Bees, Ants, Wasps.

Diptera-(Two wings), Flies.

Odonata, Dragon Flies.

Ephemerida, May Flies.

Plecoptera, Stone Flies.

Neuroptera-(Nerve wings), Dobsons, Lace-winged Flies, Ant Lions.

Siphonaptera, Fleas. 



\section{CHAPTER VII.}

\section{FIELD WORK ON COLEOPTERA.}

When on the way to the "happy hunting grounds" of beetles, it is to be remembered that the beetles most easily found are the beneficial sorts, hence one must not make haste to kill all the beetles that he finds. If you wish to be sure of finding only harmful sorts, go to the granary, the wheat bins, old meal chests, flour bins; or out to the garden where potatoes, squash, or pumpkins are growing. The beetles whose eggs are laid on the bark or under the bark of trees, and whose larvæ on hatching burrow under the bark, are among our exceedingly troublesome insects; but going after them would, in the hands of an amateur, mean more harm than help to the tree. Better leave this task to the woodpeckers and the flickers; they have more sense in such matters than you and I have. On a summer evening, any blundering June bug that comes thumping against the screen door and goes sprawling on his back in the porch corner-take him! It would be a sin not to dispose of him immediately by way of the killing bottle. He may be the very same villain that, earlier in the season, lived underground and ate off the grain roots, or grass roots, or geranium roots, leaving the top of the plants to die in each case. If you are to find beneficial beetles go to the trash pile in the back yard; to the old grass or leaf pile which is partly decayed; to the manure pile in the alley; to some unburied carcass of dog, hen, or mouse. Hang a 
dead mouse up in some out-of-the-way place, and you will probably be able to attract some carrion beetles to the carcass, and then you will be privileged to watch them at their valuable work. In the dust of the farm road you may be able to discover some of the tumble bugs making away with the horse droppings to provision their nests for their young.

If you are willing to get clear down to the surface of the beaten path across a vacant lot, or the sandy ground at the edge of the garden path, you may discover the hole made by some tiger beetle. In order to go through its larval days, after the manner of all tiger beetles, it burrows beneath the surface of the ground several inches, then turns about in the hole it has made and waits till some insect comes in its way; then it hauls the unlucky victim down far into its burrow and feasts sumptuously. When it is again hungry it goes up to the opening of the burrow, and again lies in wait like some tiger in its lair. The adult tiger beetles are slim, trim-bodied insects with strong, though slender legs, big eyes, and a general air of alertness; they are swift runners and catch their preyother insects-in open fight, simply by being quicker and pouncing upon them.

Some of the most interesting of the valuable beetles cannot be found unless you go to a pond, or a river which has pools and shallows. These beetles do their work in water where vegetable or animal remains are continually collecting and decaying. These things the beetles eat, and thus serve to keep the quiet water bodies rid of this foul matter. Otherwise such waters would be very unhealthful to other creatures, as cattle, wild fowl, field animals, or the human family. In going after these beetles one must take a new pail, not an old rusty one, a 
rake, and some sort of dipper. The water net may be used, or an ordinary tin dipper tied to the end of a long stick will do very well. Or someone of the party may wear hip boots, and you can make him do all the "bagging" of the game.

The water scavenger beetles may usually be found clinging to grass stems under water; though they may be found occasionally coming to the surface for a store of air,

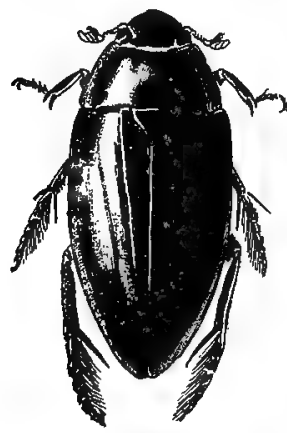

FIG. 24 .

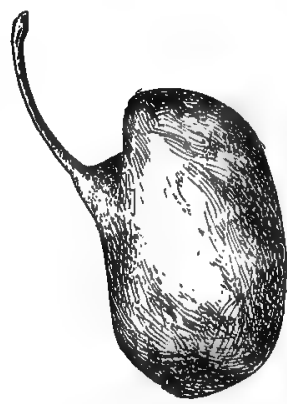

FIG. 25.

Fig. 24.-Great water scavenger beetle, Hydrophilus triangularis. (Natural size.) (Kellogg.)

FIG. 25.-Egg case of great water scavenger beetle. (Twice natural size.) (Kellogg.)

or as they paddle from place to place. The one who goes on a beetle hunt of this kind cannot go with whoop and hurrah, plunging with a swish into the water; that would be the last of specimen hunting for several hours at least. One has to go about it quietly, creating as little disturbance as possible in the region to be investigated. It is a sort of a Mahomet-going-to-the-mountain game. If you give them half a chance to know that you are coming they will disappear; and don't think that they will come out again until they are reasonably sure that 
you are out of their way. It takes patience; but it pays. To discover God's sure and marvelous ways of working,

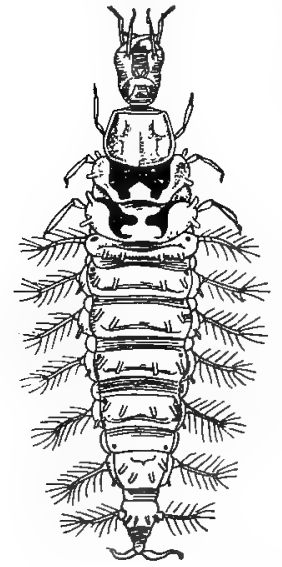

FIc, 26.-Larva of great water scavenger beetle. (Kellogg, after Schiodte.) in these tiny creatures, cannot fail to make the discoverer desire to live more fully and faithfully in doing his own tasks from day to day.

For flower beetles, one should go to the woodland, the pasture, or the hillside, where elder bushes, golden-rod, yarrow, or wild asters grow. Beat a flower cluster over your handkerchief, and you may beat out several kinds of beetles which have been eating pollen -and this is Delmonico fare for these beetles-and incidentally pollenating the various flower clusters, therein lies the value of the beetles, of course.

The next family of toad stools you find, pick the ripest of the big ones, and there may be found among the gills of the old top, flattish, rather small, slim-bodied beetles, with short wing-covers. These are the rove beetles, and the service rendered is that of scavengers. In all this you do not have in mind the pursuing and killing of insects, but the knowledge which can come only through finding the beetle in its haunts and following it around to see how it lives and moves and has its being. There will always be room for another Agassiz, and who knows where he will be found?

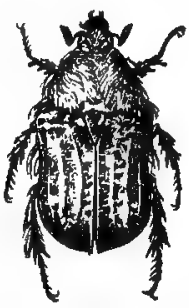

FIG, 27.-A flower beetle, Euphoria inda. (Kellogg.)

The one who best studies aquatic insects of all kinds does so flat on his face, watching the water depths for 
the queer happenings there. An occasional fly or moth may fall into the water, and one of the diving beetles will dart alongside and appropriate the unlucky insect for its noonday meal. Across the surface of the water, in straight lines, zigzags, or circles, go the whirligigs. After watching them for some time to see whether they swim in schools or singly, whether they dive when nothing disturbs them, and what they eat, it will make an interesting study to make the attempt to get some of them into your pail. If you succeed in capturing one, turn it on its back, and you will be rewarded by seeing it put out its antennæ and work its oar-legs back and forth. Notice whether the antennæ are thread-like or clubbed or flattened on the outer end. The two hind pairs of legs are short and very much flattened and a little widened-excellent oars! The front legs are longer and very slender, not good rowing instruments, but excellent "hands" to seize such food as may come in their way.

At night, when summer has really come, the fireflies may be seen, at first rising out of the grass where they have been during the day. The next morning a little search of the place where you saw them rise the night before, may reveal some of these fireflies down near the ground. Are they eating or resting-sleeping? When fireflies first begin to appear in the summer a little patient digging below the ground surface in the same region may find some of the larva, worm-like creatures. It is supposed that both adults and larva are carnivorous, eating soft-bodied animals smaller than themselves.

On the potato tops, search for the leaf-eating tenlined potato beetle, with cream-colored body and ten dark lines running lengthwise of its elytra. A search will surely reveal larvæ, pupæ, eggs, and adults in the 
same field. Can you find small and large larvæ? Do these beetles have any enemies coming under your observation here?

In setting up a beetle to go into the collection box the pin should go through the body to one side of the middle line, through one of the elytra, never between the elytra. Set the beetle well up toward the top of the pin, on the upper third, perhaps, so that the insect can be handled conveniently, and at the same time the legs will be far enough above the paper to be removed from the danger of being broken off. In classifying a beetle it is necessary to know the number of joints in the tarsus, whether the joints are all equally movable upon each other or not. The insertion of the basal joint of the hind leg, with respect to the first segment of the abdomen, also comes in as part of the necessary means toward finding what particular beetle you may have under examination. 


\section{COLEOPTERA.}

\section{CHARACTERISTICS.}

I. Hard, horny, or thick, leathery front wings.

2. Thin, gauzy hind wings, folded under front wings when the insect is at rest.

3. Mandibles developed for seizing food; some sorts have very large mandibles.

4. Some members of the order have the wing-covers short and the wings also short; these beetles run rather than fly. 



\section{COLEOPTERA.}

This is the order of the beetles. It is made up of the insects often called bugs, but which are really not bugs at all. The name, Coleoptera, is made from two Greek words, koleos, sheath, and ptera, meaning wings; hence the Coleoptera are the Sheath Wings among the insects. The front wings are usually hard and horny, often brilliantly colored and shiny. They are not useful for flying, but are literally sheaths for the true wings, which lie under these sheath wings. The true wings are thin and gauzy, are considerably longer than the sheath wings, or elytra; and when not in use are folded once lengthwise, plaited like a fan, and then are tucked away under the elytra. If one watches a beetle just settling from flight, one may see these gauzy flight wings and just how they are disposed when the beetle alights.

Some of the characteristic beetle haunts may already be known to the student of, insects. Some beetles must be looked for in the pond or the river; but most of them are terrestrial in habit. In the back yard, under stones, boards, and leaf piles; under the woodpile; in the neighborhood of some decaying carcass; under the bark of some old stump; under the umbrella-like top of some toad stool; in the hot, dusty road; or scuttling across your path into the friendly shelter of the weeds and the grasses; in the golden-rod and the blazing star clusters; on your melon vines or in your cabbage patch; around the edges of your carpets; in the flour bins or among the stored grains-in any of these places and many more you may 
expect to find beetles. The order includes some of our most beneficial insects and some of our worst fruit-eating and grain-eating pests.

Government entomologists have given us some very startling figures on the enormous yearly losses in growing crops due to insects of the harmful sorts. According to Riley, the yearly loss from grain- and fruit-eating insects foots up $\$$ I $5,000,000$ more than the cost of all our common schools and our higher institutions of learning. Losses are usually estimated in dollars and cents; that is, what the products would have brought us if they had been allowed to mature. But an equally serious view, if not more serious, is the loss sustained from the point of view of the time and labor expended without a fair return. We are told that an annual loss of ten per cent. is suffered yearly by agriculturists and fruit-growers the world over. This is enormous, and. would not be endured year after year if it occurred from almost any other cause. When one reflects, it becomes plain that this loss comes about mainly through ignorance of the causes, and partly through neglect of known effective measures of prevention, as well as through the conscious or unconscious disturbance of the laws which preserve the balance of nature, whose free operation serves to enable one pest to keep in check another pest, or one tribe of predaceous animals to decrease the numbers of an injurious tribe. Take, for example, the indiscriminate slaughter of the prairie and woodland snakes; hardly anyone would allow a blue racer or a bull snake or a garter snake to escape; and yet the gradual killing out of these snakes in certain neighborhoods has led to large crop losses through the unrestrained increase of gophers, chipmunks, mice, and other animals which constitute the food of these valuable 
animals. Annually, large numbers of these animals are killed, which are doing their best to preserve the balance of nature. Destroy a friend and you invite his enemies to become your enemies. Destroy predatory insects and birds-insectivorous birds-or the weed seed-eaters among the birds-and you invite a train of evils beyond your power to control. Much patient investigation is necessary if we would make use of these friends, also readiness to make use of information whenever it offers in order to know which insects to protect and which to hunt and kill. Be it said for birds, before we approach the subject more closely, that there are almost no birds in our agricultural districts that do not do more good than they do harm. Again, a plant-eating insect is not to be condemned outright, for many plant-eaters among the insects help to keep noxious weeds in check.

Some of the beetles which are beneficial to the farmer and the fruit-grower, and which should be protected by them-and by all other people, for that matter, since, so long as we eat food, none of us can get away from our connection with the soil and its products-are:

Ladybird beetles

Carrion beetles

Checker beetles

Soldier beetles

Blister beetles

Diving beetles

Tiger beetles

Tumble bugs
Dung beetles

Rove beetles

Whirligigs

Water scavengers

Fireflies

Flower beetles

Ground beetles

Among the list of beetles just mentioned there are some that deserve special notice, not only for their helpfulness, but also because their feeding habits are such that 
they are more easily caught than are the harmful insects upon which they prey. Such are the ladybirds, small round-backed beetles, with reddish or red wing-covers, usually marked by some black spots. (Fig. 28.) Then, again, some of them are of medium or large size and brightly-colored, hence easily seen. One or two of these ought to be mentioned. The Searcher is one of the largest of the ground beetles, measuring about two inches
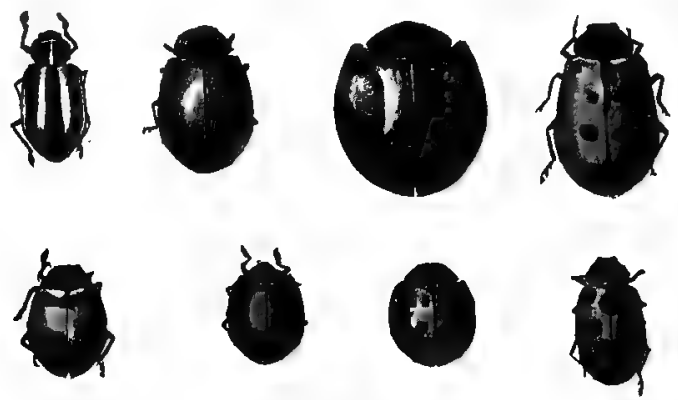

FIG. 28.-Some California ladybird beetles; beginning at left of upper row, the species are Megilla vitigera, Coccinella californica, Coccinella oculata, Hippodamia convergens; beginning at left of lower row, Coccinella trifasciata, Coccinella sanguinea, Coccinella abdominalis, Megilla maculata. (Kellogg.)

in length, reckoning in the widely extended, slender legs. (Fig. 29.) The hind part of the body is much wider than the head and the thorax. Its handsome wing-covers are green with a red stripe around the outer edge. The under part of the body is brilliant with shades of blue, green, copper, and bronze. This beetle is known to prey extensively upon cut-worms and to climb trees in search of the gypsy moth caterpillar. The Fiery Hunter is another of these valuable beetles. It is a little slenderer than The Searcher, but its appearance is similar. The wing-covers are blackish, marked with rows of bright red or copper- 
colored spots or pits. This beetle eats large numbers of cut-worms and 'wire-worms wherever they are found.

Many of the ground beetles, all of which are beneficial, are blackish-brown or black, and are often found running about on the ground or over rubbish and manure piles. These all have slender legs and are good runners. Their business is honest and legitimate, and they do not hide or skulk while they are about it. They are all predaceous or are valuable scavengers, and should be carefully protected from injury. Take, for instance, the beetles to

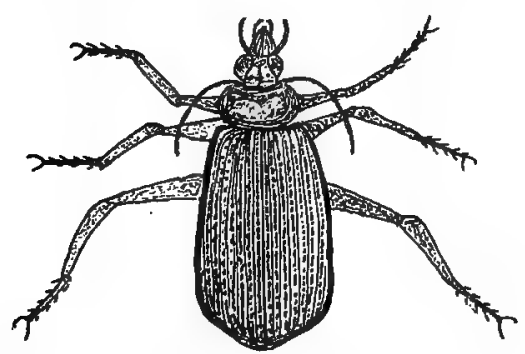

FIG. 29.-The Searcher.

which has been given the name Harpalus. These are eminently helpful beetles. They are of various sizes, pitchy-black in color, compactly built, thorax and abdomen of equal width, and the head about half as wide as the thorax. The sclerite covering the prothorax is nearly square and meets the wing-covers in a smooth tight joint without constriction or ridge. Some of these beetles are known to frequent orchards, where they search for the larvæ of plum curculios and codling moths. Another Harpalus likes especially the army worm. Some others of the ground beetles are dull brownish-black, while others have metallic wing-covers. 


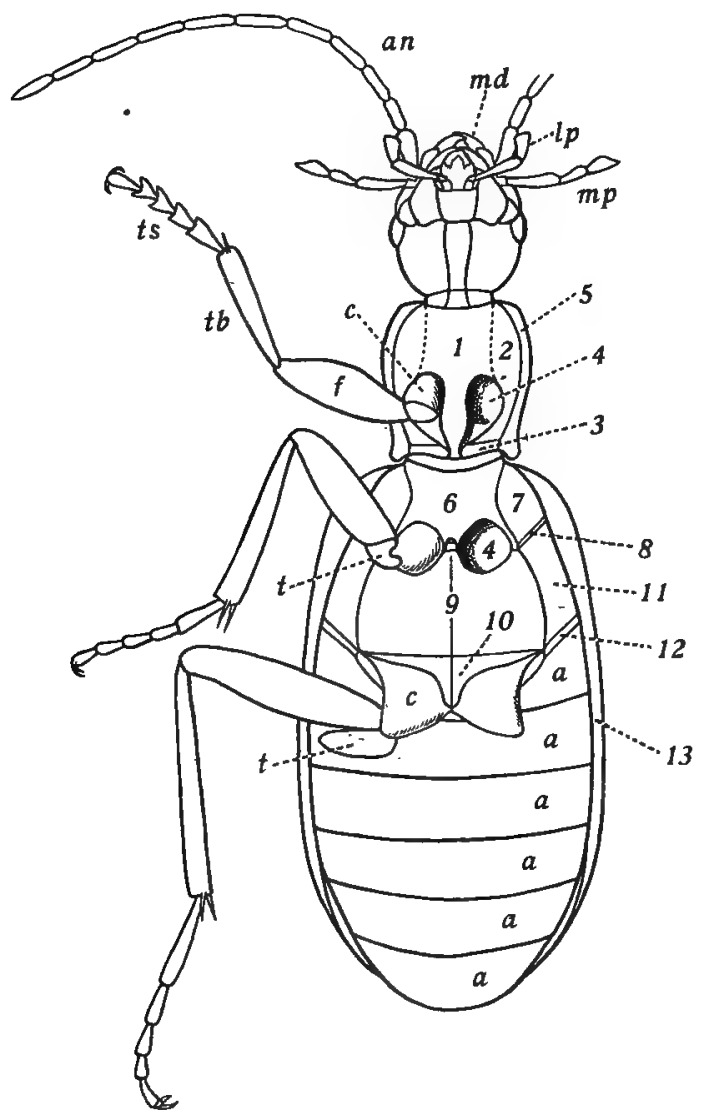

FIG. 30.-Ventral aspect of a carabid beetle, Galerita janus. I, prosternum; 2, proepisternum; 3, proepimeron; 4, coxal cavity; 5 , inflexed side of pronotum; 6, mesosternum; 7, mesoepisternum; 8, mesoepimeron; 9, metasternum; Io, antecoxal piece; II, metaepisternum; I2, metaepimeron; I3, inflexed side of elytron; $a$, sternum of an abdominal segment; an, anlenna; $c$, coxa; $f$, femur; $l p$, labial palpus; $m d$, mandible; $m p$, maxillary palpus; $t$, trochanter; $t b$, tibia; ts, tarsus. (Folsom.) 
Some of the beetle pests whose enemies ought to be protected, and whose effective destruction ought to be sought with every appearance of the pests are:

Fruit and grain weevils

The Borers

Rose chafers

Flea beetles

Potato beetles

White grubs

Carpet beetles

Curculios

June bugs

Wire worms

Cutworms

Leaf chafers

The elm-leaf beetle is one of the most destructive enemies of forest trees, and it should be recognized and destroyed wherever found. The beetle is yellowish with some black spots on the thorax and one black stripe on the inner edge of each elytron. The prosternum and the legs are yellow; the remaining under parts are back. It is about a quarter of an inch long. Its yellow eggs are to be found on the under sides of the leaves in masses, and these should be crushed whenever found. From these eggs hatch larvæ or grubs, marked with black or yellow; these skeletonize the leaves, or eat out the green parenchymatous parts of the leaves, leaving the veins and part of the epidermis. They then pupate, and when ready to do this they crawl down the trunk of the tree and burrow a short distance beneath the surface but close to the roots, or rather to the trunk of the tree. The adult beetle winters over, under old leaf piles, in other rubbish, or in the hollows of trees. Domestic fowls, robins, bluebirds, thrushes, cedar birds, and catbirds are the most effective enemies in getting rid of these pests, both in the adult and the larval stage. There is always, in such cases, some effective bird ally which can be relied upon to accomplish the destruction of the insect pest. Encourage, 
then, the coming of the birds, and protect them after they are with you by insisting that they shall not be molested, neither as to their nests nor as to themselves. Insure a bird's personal safety, and he will stay with you and will bring along his family and a host of relatives besides.

Other insect pests of the beetle kind and their destroyers might be mentioned:

\section{Potato beetle}

Rose-breasted grosbeak Quail

Mongolian pheasant Yellow-billed and black(lately introduced) billed cuckoo

\section{Weevils and leaf beetles}

Yellow-billed and black- Towhees

billed cuckoos

Sparrows

Phoebes Kingbirds English sparrows Red-winged blackbirds

\section{Twelve-spotted cucumber beetle}
Quails
Prairie chickens

Grubs of various kinds, principally of May beetles

Domestic fowls

Robins

Blackbirds

\section{Click beetles}

Flickers

Phoebes

Baltimore orioles

Kingbirds

Yellow-billed and blackbilled cuckoos

\section{May beetles}

Blue jays

\section{Borers}

Downy woodpeckers Flickers

Hairy woodpeckers 
In the light of this body of facts and many others that might be enumerated, the fruit-grower and the farmer should not only use insecticides, but should also avail
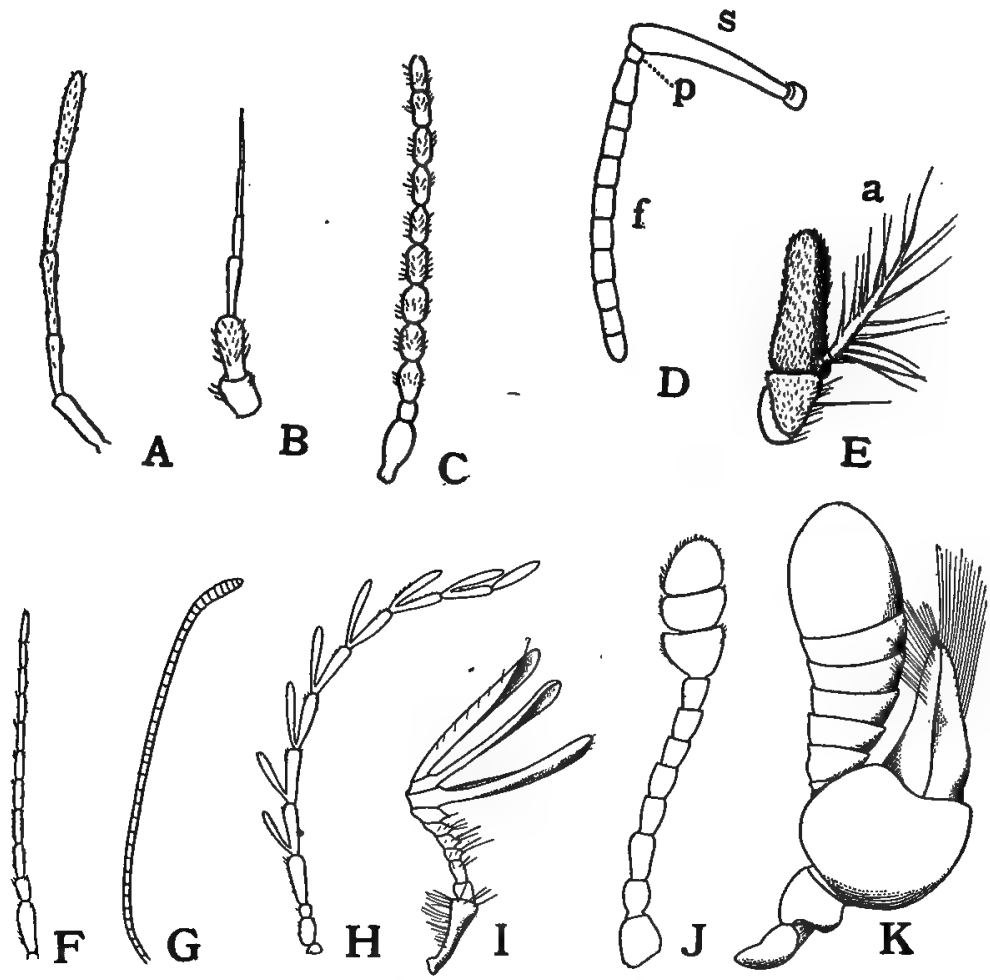

FIG. 3I.-Various forms of antennæ. A, filiform, Euschistus; $B$, setaceous, Plathemis; $C$, moniliform, Catogenus; $D$, geniculate, Bombus; $f$, flagellum; $p$. pedicle; $s$, scape; $E$, irregular, Phormia; $a$, arista; $F$, setaceous, Galerina; $G$, clavate, Anosia; $H$, pectinate, male Ptilodaclyla; $I$, lamellate, Lachnosterna; $J$, capitate, Megalodachne; $K$, irregular, Dineutus. (Folsom.)

themselves of the services of their bird neighbors by protecting them to the full extent of the law; and where no law covers the case they ought to be wise enough to 
accomplish the enactment of a law which will protect their bird friends from the heedless small boy with sling shot or rifle, and from the man who hunts simply for the sake of killing.

The families of beetles listed as beneficial beetles are to be understood as having gained this place through their habits of feeding upon other insects which are injurious to valuable plants or to predaceous insects, or are

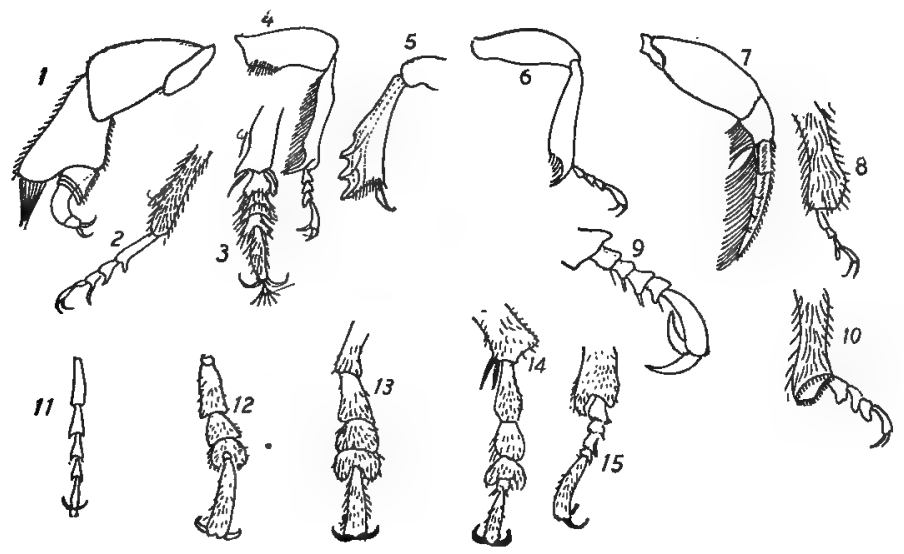

FIG. 32.-Different forms of legs and tarsi of beetles. . (Kellogg, after LeConte and Comstock.)

useful because of the beneficial habit of eating decaying animal remains, excrementitious matter, and other refuse; or they may be pollenizers of flowers.

Structurally, the beetles differ from the bugs in another important respect. Their mouth parts are adapted for biting and chewing. They have strong mandibles and well-developed palpi. This order of insects has thousands of representatives, and is one of the most, if not the most, difficult to classify, owing to their almost endless 
diversities of form. The forms of coleopterous antennæ and tarsi are various, and constitute type forms for naming antennæ and tarsi of other insects. (Fig. 32.)

With the exception of the blister beetles, all the Coleoptera have complete metamorphosis. They lay eggs, which hatch into larvæ or grubs; these increase in size and moult several times, then pupate; and, after a time,

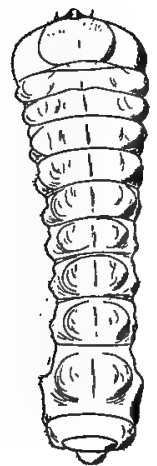

A

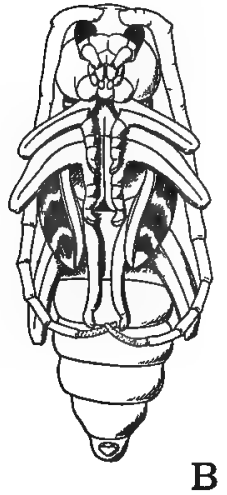

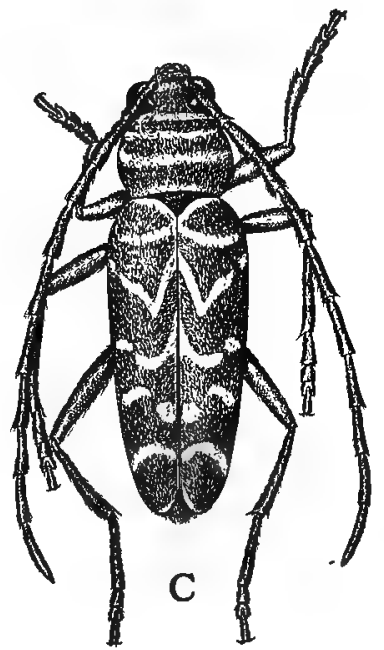

$A$, larva; $B$, pupa;

Fig. 33--Metamorphosis of a beetle.; Cyllene pictus.
C, imago. $\times 3 . \quad$ (Folsom.)

emerge from the pupal case, adult beetles. (Fig. 33.) The blister beetles, where their life history is known, als lay eggs; but the larval stage is much extended, and after the different moultings the insect assumes different larval forms suggestive of other beetles in their larval stages. (Fig. 34.) The first larval form is peculiar to the blister beetles, and is given the name of the triungulin larva; the second larval form is much like the larva of a ground beetle; the third moult reveals a new larva somewhat like 
the June bug larva, but straighter and smaller; after the next moult there appears a larva much resembling the June bug larva, even to the curving of the lumpish body. The insect grows rapidly from now on, and then pupates; but even the pupation is strange and much extended. The larva digs into the ground a little way and moults
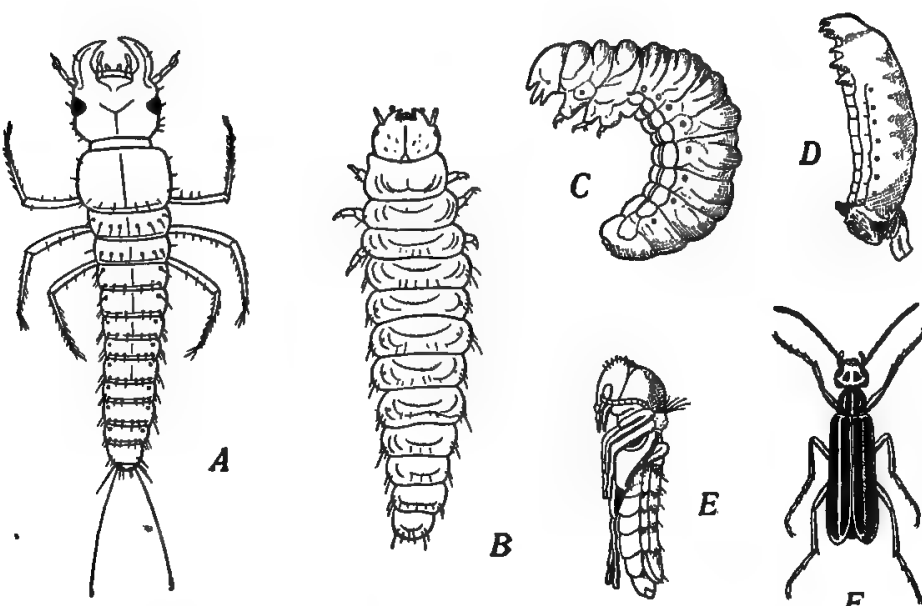

FIG. 34--Stages in the hypermetamorphosis of Epicauta. A, triungulin; $B$, carabidoid stage of second larva; $C$, ultimate stage of second larva; $D$, coarctate larva; $E$, pupa; $F$, imago. $E$ is species cinera; the others are viltata. All enlarged except $F$. (Folsom, after Riley, from Trans. St. Louis Acad. Science.)

a fourth time, and frequently passes the winter in this stage; in the spring two more moultings may take place, and then comes the pupa stage proper; this lasts for only a few days, and then out comes the adult blister beetle like its father and mother. Some of these blister beetles feed on locust eggs, others eat potato leaves alongside the potato beetles, and others feed on bees' eggs and honey. In the immature stages, so far as known, their food consists of eggs laid by other insects. 


\section{CHAPTER VIII.}

\section{FIELD WORK ON ORTHOPTERA.}

If the school-house is near fields and farm lands, the study of insects is easy; but trolley car or steam car, or wagons may be utilized for putting one's self in touch with regions where insects of many kinds live and work. A dead insect is not so profitable for study as is an insect alive; the most interesting facts of the insect's everyday living are lacking if you take the insect out of its natural surroundings. Hence there must grow upon the student of insects the habit of observing what is going on about him in places where insects live, what the insects are doing, and whether any other living being, plant or insect or man, is the gainer thereby.

The food-getting instinct is at work in the will of the grasshopper when he eats up our lawn grasses and shrubbery; and it is a successful insect from the grasshopper point of view, though not valuable from the human point of view at all. Some knowledge will already be in possession of the students as to where to go to look for hoppers and crickets. Sunny hedge rows; hot dusty roads; late garden patches-all should be visited for grasshoppers and locusts.

\section{Discover :}

Whether their colors are protective so far as you are concerned,

Whether they have any enemies besides yourself,

Whether they sing at this time of day, 
Whether the locusts sing at any time.

It is a very difficult matter to catch the leaping orthopters without something to lengthen one's reach, so be sure to take your insect net on this trip.

Late in the afternoon of some summer day, while you are sitting on the veranda, you may hear a shrill singing. Get up and follow the sound, cautiously so as not to disturb the singer. If it sounds like an unusually shrill cricket song you may have to peer around considerably before you see the pale, ghost-like creature, with the big voice but the small body. Ten chances to one it is a tree cricket, and you will find it on the vine or some near shrubbery, in the shadiest portion, singing for very happiness as it begins searching for its evening meal. Can you find what it is eating? Is it a male or a female cricket? Can you tell from its mouth parts, and from where it is found, whether it sucks liquid food or eats leaves?

Praying mantids may be looked for at the same time, or they may be found out in the flower garden, crawling warily about from stalk to stalk, praying occasionally, with uplifted hands, that some insect may come their way. During the height of summer these mantids will come to your light if you leave your window open. In September, or later, they may be quite sluggish, when you find them on plants or shrubs. They will probably have laid their eggs by that time, and are soon to end their lives, their good work done, and their mission of providing for their young accomplished; hence it will not be wrong to catch them for your examination or to put them into your collection box; although a collection is valuable because you know about what you have in it, and not for the specimens themselves. 
After nightfall, in a barn feed-room, or in some bakery, or press-room of a daily paper, or sometimes in the most cleanly kitchen, especially if it is in an old house, if you step carefully and keep still for some time after entering, then suddenly strike a light, you will be almost sure to find some roaches, big or little. Around a wood pile, where there is plenty of chips, you may find our native roach, shining black, and darting slippery-wise among the chips as you try to get it. Around the drain-pipe of the wash-room look for the light-brown, thin-bodied croton bug.

On your trip to the open meadows look for field crickets and meadow green grasshoppers with long slender antennæ which they wave solemnly up and down as they look at you, that is, if you keep still.

If you wish to find walking sticks you will have to go to trees or shrubbery, and look on the bare twigs for this new sort of twig. You will find that the one additional requisite for insects that are colored like the things they live on, is to remain motionless when an enemy is around. So you will have to be patient long enough to quiet their suspicions, before you will be rewarded by seeing them go about their business naturally and unafraid. And then will be your chance to learn about them.

Crickets, contrary to the usual belief, are not uniformly eaters of clothing, and therefore to be killed on sight. Field crickets, out-of-door crickets of all kinds, would not know cloth if they saw it, and certainly would not know it for food. The domestic cricket is somewhat a vegetable feeder, but is more likely to be a scavenger; so do not relegate to the gasoline bottle every cricket. you find. 
Praying mantids may easily be captured, as they do not usually fly; but you must be careful to keep your fingers out of the reach of their strong mandibles. It is better to offer them a twig or a leaf to sit on than to offer your finger. They may be kept a considerable length of time if they are provided with food, and they will be content to stay only under those circumstances; you must also give them a drink once in a while. Such insects are used to drinking the dew or the rain drops off the plants over which they crawl; so if you lightly sprinkle a mantis you will probably be delighted by seeing the curious way it has of drinking, bringing the big front legs into use for drawing down some water drop from the top of the head or the eye, and slowly sucking it in through the thirsty mouth. They like flies especially, also cabbage worms, gnats, young and soft-bodied grasshoppers, and will even eat caterpillars. If it is a female mantis, and you are able to keep her till late in the summer, the egg mass will be likely to be found around where she has been living, though she may have been shrewd enough to glue them up in some place where you will be unlikely to find them, that is, if she has formed the opinion that you are only a very big insect after all; for, like all careful insect mothers, she looks well to the safety of the little mantids, although she is never to see them.

In setting up a locust for a collection the pin should be thrust well through the thorax, so that the jumping legs and the shorter front pairs will rest on the ground in natural position. Then set the pin with the insect on it, into the trough of the drying board. Spread one elytron by lifting it first up, then outward; then spread the flight wing on the same side, and weight both down witr square of glass. Let the locust remain long enough in 
drying board for the wing joints and ribs to dry, and the wings thus keep their position. The insect may then be put away in the collection box. It will not be necessary to spread the wings of any others of the order; the points of classification necessary for the other orthopters rest on other characteristics. 



\section{ORTHOPTERA.}

\section{CHARACTERISTICS.}

I. Front wings straight-margined and leathery or parchment-like and overlapping when not in use; used as wing-covers and as balancers.

2. Hind wings used for flight, variously colored or colorless, and folded fanwise when not in use.

3. Effective mandibles, either smooth or notched on their inner edges.

4. Cockroaches

(a) Body thin and flattened.

(b) Mandibles notched.

\section{Praying mantids}

(a) Front pair of legs much larger than the other legs and fitted for seizing and grasping.

Short-horned grasshoppers.

(a) Hind pair of legs much stouter than the other two pairs.

(b) Antennæ shorter than the body.

\section{Long-horned grasshoppers.}

(a) Hind pair of legs stouter than the other two pairs.

(b) Antennæ longer than the body.

\section{Crickets.}

(a) Hind pair of legs stouter than the two other pairs.

(b) Antennæ long and slender, often much longer than the body.

\section{Walking sticks.}

(a) The three pairs of legs similar but long and very slender.

(b) Body stick-like. 



\section{ORTHOPTERA.}

The name of the order is derived from the straightmargined, nearly parallel-sided front wings or elytra. All the Orthoptera have biting mouth-parts, and bite off and chew their food, which is usually living plants, especially green leaves; although there is one family within the order which preys on other insects, and another family prefers dried vegetable or animal refuse.

The metamorphosis is incomplete, the young, when hatched, resembling the parents except in size and possession of wings. This is the order of the grasshoppers, the katydids, the crickets, the cockroaches, the praying mantids and the walking sticks. In the early days of the spring one may find tiny grasshoppers which have recently hatched out; tiny slow-moving creatures, which do little leaping at this stage of their existence. Among the leaping Orthoptera the hind legs are very large and strong, and when the insect is standing still or walking, the knees stand much higher than the back of the insect. (Fig. 35.) During the summer evenings, from twilight until dawn comes over the eastern hills, one may hear the constant hum of insect voices, or rather sounds without voices, for no insect has vocal chords which may be set into vibration by currents of air after the manner of the human voice production. Almost all this music comes from the Orthoptera. Besides the booming of the bumblebee, the buzz of the flies, and the shrilling of the mosquito, there is but one famous singer, and that is the cicada. 
Besides being singers, the Orthoptera are high jumpers. Talk of "high jump" records! Any lusty grasshopper goes a long way toward beating the world record every time he jumps. If he sets his heart on a juicy leaf six feet away, lo! he is there. Or, if you pursue him, he will do an eight- or a ten-foot stunt before he will let you catch him. Think of an insect two inches long jumping, say, eight feet, ninety-six inches! At this rate

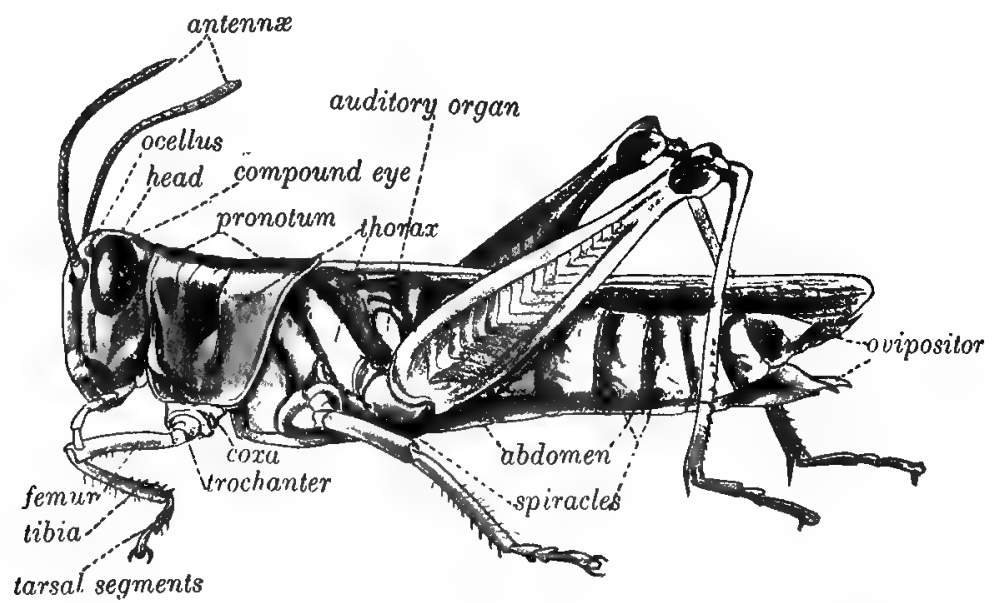

FIG. 35.--Locust (enlarged) with external parts named. (Kellogg.)

a six-foot man would have to jump two hundred eightyeight feet to keep up with the humble grasshopper. But, then, the record of the grasshopper, marvelous as it is, is not to be compared with the capabilities in that direction, of the fleas. An ordinary flea, under stress of circumstances, will jump from four to five feet; that is, an insect one-eighth of an inch long will jump fortyeight or sixty inches-three hundred sixty-four or four hundred eighty times its own length. This is a long 
way ahead of the proud genus Homo, and the fleas have no preliminary training for such extraordinary feats, either.

Of the six families composing the order, three are silent and do not leap, though there are some extraordinary runners among them; and the other three families both sing and leap. This music is all night music, however; for if a katydid were to betray his whereabouts. while the birds are astir, there would not be left enough of him to tell the tale. This singing is done in different ways

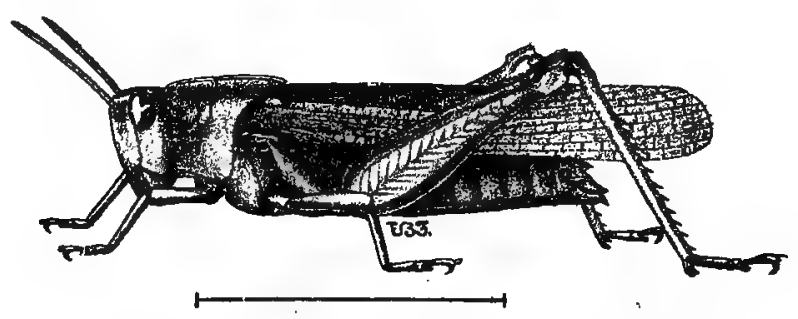

FIG. 36.-A short-horned grasshopper. (Kellogg.)

by different members of the order. When the locust sings at rest, it is rasping the inner surface of the broad hind thighs across the roughened surface of the front wings as they lie close to the sides of the body, much as one draws a knife across a whet-stone, only back and forth. When the locust rattles as he goes whizzing through the air, he is striking the front margin of the hind wings back and forth over the hind margin of the front wings. When the cricket sings on the hearth, he is holding up his front wings at an angle of about forty-five degrees, and is rubbing together the specially modified surfaces of their basal regions. The tree crickets, the katydids, and the meadow-green grasshoppers have much the same musical apparatus as have the crickets. This insect method of making sound is called stridulation. 
According to Comstock, the three singing and leaping orthopterous families are the Acrididæ, short-horned grasshoppers; the Locustidæ, long-horned grasshoppers, generally green; and the Gryllidæ, or crickets.

The short-horned grasshoppers are the grasshoppers commonly called locusts. The Lubber grasshopper of the South and the West belongs here. Its body is large and clumsy, and its wings are reduced to mere pads.

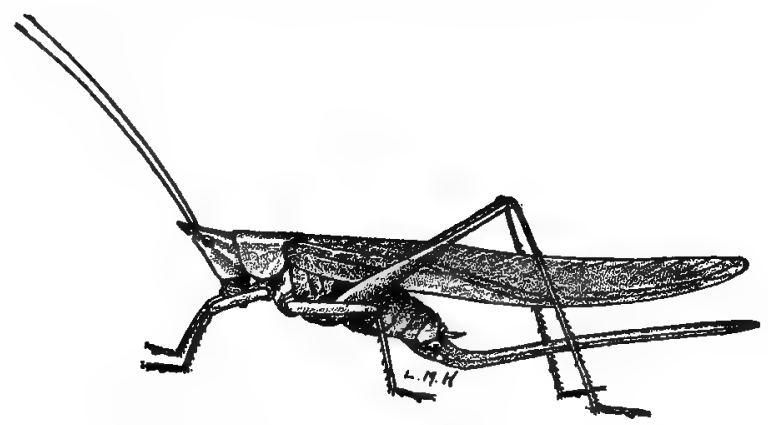

FIG. 37.-A long-horned grasshopper. (Kellogg.)

The second class, really the locusts or long-horned hoppers, includes the meadow-green hoppers, (Fig. 37), the katydids, with long thread-like antennæ often longer than the body, the shield-backed grasshoppers, and the cricket-like hoppers.

In practically all of these, the hind legs are longer than the front legs or the middle pair. The shield-backed grasshoppers are wingless and are known by the fact that the pronotum, or shield on the upper part of the body just back of the head, extends well back over the thorax and the base of the abdomen, like a cloak thrown over the shoulders. The cricket-like grasshoppers are to be looked for around old weil curbs or stone piles, in damp, dark 
places generally. The body is shining dark brown, thick, and arched upward in the thorax and front abdomen, while the head is curved downward between the front legs. The antennæ are long and thread-like, and are usually carried backward over the body, when not in use to acquaint the insect with its surroundings. (Fig. 38.) Their haunts are not such as to give one an idea of the food habits; but as they seem to be nocturnal in their habits the indications are that they eat both animal and vegetable food. The katydids of the lowland regions and the plains

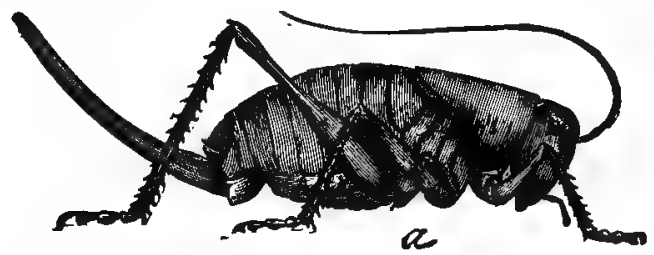

FIG. 38.-A cricket-like grasshopper, Anabrus simplex. (Howard, after Riley.)

are green-bodied, green-winged Locustidæ. They are nocturnal and are hard to find; a pair of sharp eyes searching around vines or trees or bushes late in the afternoon of a summer day will possibly be able to find them. Some of them have wing-covers so closely resembling leaves both in form and color, and even venation, that seeing is oftentimes not believing. This is one of the cases of protective resemblance, the protection sought being from birds. The scheme does not always work, however; one could not spend a single afternoon among the feathered tribe and the insect folk without discovering this fact. But it is only natural to suppose that birds have not been napping in the midst of the schemes of their insect neighbors, but have pitted their own sharpened. wits against the various devices employed against them. 
Another case of protective coloring is found among the tree crickets, delicate, pale-green, shadowy insects to be found in among the foliage of vines, shrubs, or trees. The male tree cricket has a way of closing his wings flat on his back, so that they extend out some distance from the side of his body and make him look larger than he really is; while the female folds her wings downward around the body. Both are leaf eaters, and if they were more abundant or had fewer enemies, they would be quite injurious to vegetation. A tree or a shrub denuded of its leaves is unable to ripen its fruit for any given season, or to make its buds for the next season.

Scudder mentions finding grayish katydids in mountainous regions, and says that their quiet colors were quite as effective against the granite rocks as is the green of our katydids among growing vegetation.

The three families of Orthoptera that do not sing nor walk, and run instead of leaping are the cockroaches, the praying mantids, and the walking sticks. The cockroaches are among our oldest insects. More than two hundred different kinds have been found preserved in the carboniferous rocks of North America and Europe. They could hardly have been scavengers in those days, as there were no kitchens nor restaurants for them to ransack then. They were probably plant-eaters, as our native roaches are to-day; or they may have been predatory creatures; roaches indoors nowadays will often devour bedbugs.

Many of the roaches at present found in the United States were imported from Europe, brought over in the holds of ships, and, coming ashore with baggage or with the luggage of immigrants, are given access to many buildings, warehouses, and homes where a comfortable 
living awaits them. These insects are indoor dwellers, purely nocturnal in their habits, haunting store-rooms, pantries, and sinks after night comes. The light brown, rather small roach, brought over from Germany to New York, received the name of Croton bug from its insistent connection with the city water system. (Fig. 39.) These introduced roaches have spread rapidly, probably at first

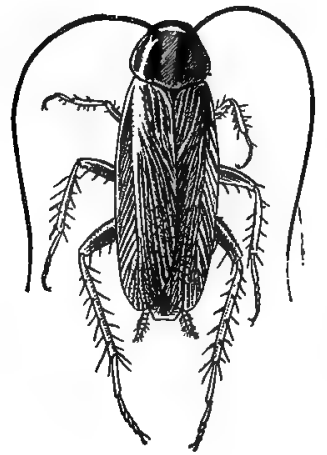

FIG. 39.

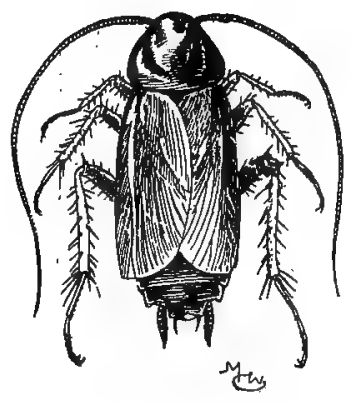

FIG. 40.

FIG. 39.-The croton bug, or German cockroach, Ectobia germanica. (Twice natural size.) (Kellogg.)

FIG. 40.-The oriental cockroach, Periplaneta orientalis. (One and onehalf natural size.) (Kellogg.)

largely following the main travel lines across the country, until they now breed from New York to San Francisco. The oriental roach, brought in by way of the Asiatic steamers, has been spreading eastward. (Fig. 40.) The last-named roach is about one inch long, with a brownishblack body. The wings of the male are not quite so long as the abdomen, leaving about the last two segments exposed. The native roach most like the oriental roach is about an inch and a half long, much lighter in color, and the wings completely cover the abdomen. This roach 
came northward into the States from Mexico. Aside from this species, our other native roaches live around wood piles or under the bark of trees or old stumps, or other out-of-door convenient hiding-places, from which to set out on their foraging trips. (Fig. 4r.)

The mouth-parts of the roaches are fitted for masticating dry, hard substances. The jaws are strong and

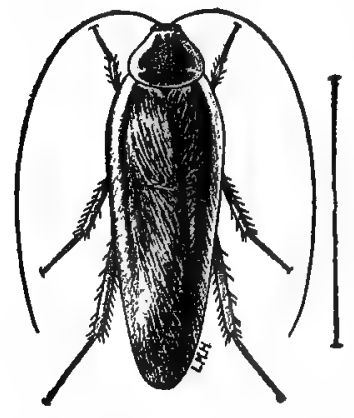

FIG. 4I.-Common native cockroach, Ischnopter pennsylvanica. (Kellogg, afterLugger; natural size indicated by a line.) toothed, and the insect appreciates especially hard bread or crackers, or dried bits of the lunch that you did not eat up. Failing these things, he will be quite happy to regale himself on the leather binding of your Shakespeare, or your winter coat, wall paper, or the paste of book bindings if he can get into your bookcase.

The cockroach body is flattened and very smooth, and the legs are adapted for swift running, altogether making it an insect hard to catch. If you have not tried catching one, test the truth of the statement. The insect has no trouble in concealing itself in a crack or a crevice. The eggs are laid in small cases which are carried about by the mother until the young are ready to hatch. The young, as soon as they are hatched, begin to run about and take care of themselves; but they grow slowly, taking nearly a year to acquire adult size.

The praying mantids are long, slender-bodied insects, with the curious habit of raising their large front legs up in front of their faces while they stare about them, meek and motionless of aspect. In fact they are watching for 
an insect, but they look far from carnivorous, as they stand on the edge of your book and look solemnly at you. A female of one of these mantids was recently kept in the laboratory by the writer, for more than four weeks. It was allowed the run of a bunch of golden-rod, and it seldom sought to leave its quarters. It was fed flies, occasionally catching one on its own account. It liked small grasshoppers and the caterpillars known as woolly bears, but it especially delighted in green cabbage worms, and would eat several of these "at one sitting." But one day, one of these worms, in twisting and writhing to get out of the clutches of its murderer, bit the mantis on the softer part of the leg, and thereafter the mantis would fight shy of a green caterpillar unless its head had first been crushed.

The adult males of the mantis

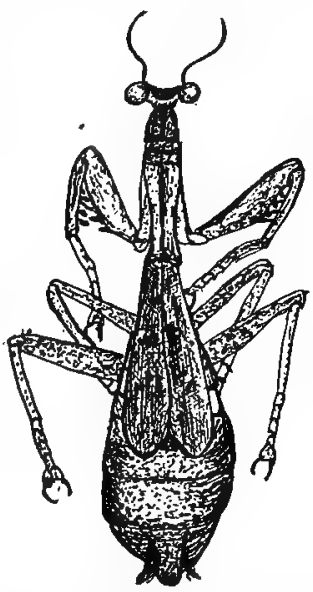
family are slender-bodied and usually grayish in color, while the females FIG. 42.-A praying mantis (female). have much broader abdomens, and often variegated wing-covers. All the mantids are useful insects and should be carefully let alone and not injured. The eggs are laid in late summer or September, usually, and hatch out the following spring. Their life habits may be much more profitably studied from the living specimens, as they readily yield to kindly treatment, being quite willing to take food from the hand, when it.is offered.

The walking sticks, as their name indicates, are curious stick-like insects, wingless and slow-moving; and their resemblance to the twigs on which they may 
be resting while feeding is one of the most effective cases of protective coloration and mimicry of form. These insects, as might be suspected, are tree-dwellers, living also on bushes or other vegetation, and keeping as close

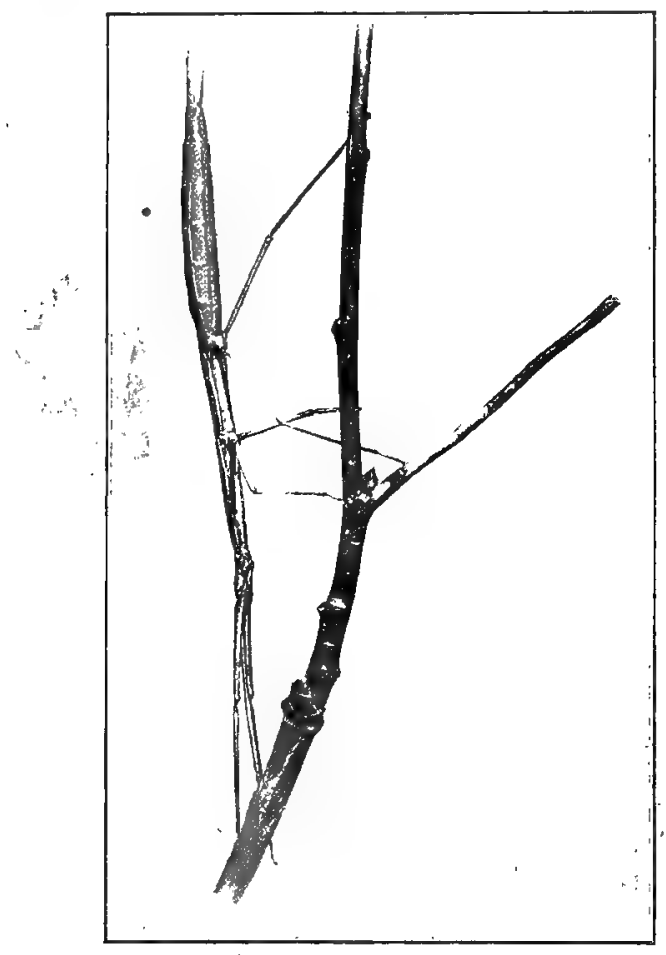

Frg. 43.-Diapheromera veliei, on a twig. Natural size. (Folsom.)

as possible to the twigs of the plant. The species generally found is brown and very slender-bodied; but occasionally there is found a green species with a slightly stouter body. And whenever one is fortunate enough to discover the brown species on the twig, or the green 
sort on the foliage, he will surely acknowledge that the walking sticks are able to cover their tracks quite effectively from both naturalist and bird.

Bird enemies of some of the orthopters:

\section{Grasshoppers.}

Quails

Prairie chickens.

Crows

Domestic fowls (ducks, geese, and chickens)

Wild geese and wild ducks Screech owls

Red-winged blackbirds

Kingbirds

Sparrow hawks

Butcher birds

Blue jays

House wrens
Night hawks

Bluebirds

Barn swallows

Yellow-billed cuckoos

Brown thrashers

Crickets.

Bluebirds

Shrikes or butcher birds

Robins

The sparrow family

Towhees

Kingbirds

\section{Katydids.}

Robins

Domestic fowls 


\section{CHAPTER IX.}

\section{FIELD WORK ON HEMIPTERA.}

Of the true bugs, ten families are aquatic; hence the same pond that furnishes material for the study of beetles, may furnish many sorts of these insects with sucking beaks.

To learn what this beak looks like, catch a squash bug or a cicada, and while you hold between thumb and forefinger either one you may have caught, look on the under side of the head, perhaps turning the insect so that you can see the head sidewise. Folded back against the thorax, between the front legs, will be found the sharp-pointed beak. When in use, it is held at a right angle with the body. Some of the predaceous members of the order hold the beak "in action" straight in front, of the head.

On the surface of the pond, or in quiet pools of the river, one may see long-legged insects darting across the water, preferring to escape from danger by more rapid skating than by diving. These are the water striders; and if you expect to catch them with your dip net, you will have to make some shrewd guesses as to where the insect is likely to be after your net strikes the water. Watch them first to see if you can discover what they are doing as they stride about over the water. Their front legs are strong and could well do for hands if the insects needed organs for grasping.

In company with the water striders, but stirring up considerably more commotion in the water, like some tiny 
side-wheeler alongside a big, steady, ocean-going steamer, are the back swimmers, performing such feats as you and I would have reason to be proud of, if we could do them, always swimming back downward, the hind legs directed forward, and so formed as to serve as oars. These are blue-gray and white insects, and they lash the water smartly as they dart here and there in search of food. If you can capture one, put it into your pail, which should be at least half full of the pond water; and you will see, especially if you have brought along the reading glass, that the rear end of the body of each of these back swimmers is tilted slightly upward, so that the wing margins are slightly above the water line. The back swimmers are airbreathing insects, and they store their air supply between the abdomen and the wing-covers.

If you stoop on your hands and knees, or lie down so that you can look into the depths of the pond-and do it quietly-there may be found other insects clinging to the grass stems or other objects under the water; these may at first sight look very much like the back swimmers, but these insects prefer to stay below the water surface, while the back swimmers come below only when something disturbs them above. The grass stems may be swept with your dip net for some of these insects, and when you have one of them in hand, if it has the characteristic beak, it is presumably a water boatman. This new insect should be flat on the back, instead of keel-shaped as the back swimmers are. You may also find, crawling about over the pond mud, a big brown insect about two inches or more long. Its two front legs are held elbowed, seeking what they may grasp. Send down your dip net or the dipper and get one of these insects; and when you have him look for the long beak "laid away" between the front 
legs. If you find the beak, turn the insect over on its face to discover whether the wings have an opaque and a transparent portion. If both facts are true, you may be sure that you have another bug; and this sort is what is called the giant water bug. Having captured and studied these bugs, empty your pail back into the pond; you have all the requisite knowledge of them, and they are useful and must be left to do their life work by living out their

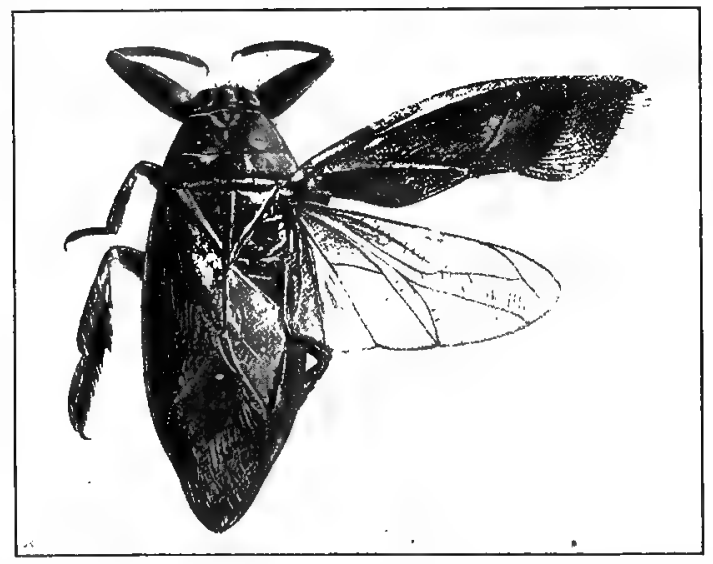

FIG. 44.--Giant water bug. Benacus griseus. Slightly reduced. (Folsom.)

alloted days, and thus fulfilling their mission. You have the really valuable knowledge when you have found that they are valuable by discovering what they are eating; if you want to know their real names, they can be brought home in the pail and kept in water renewed at least every day, with flies occasionally fed to them, while you are studying their structure and make-up carefully enough to recognize their accurate description in some one of the insect.manuals. All three of these insects have good 
flight wings under their wing-covers, and can fly readily. Later on you may meet the giant water bugs elsewhere. (Fig. 44.)

A very profitable hunting ground when seeking land bugs is the garden patch; cabbage, squash, melon, or cucumber will be sure to furnish some of the leaf-eating hemipters. The reading glass may be used to see how the squash bugs and the calico backs are eating. Along with the cabbage worms you may find their enemies, sharp-beaked, prettily colored bugs, carrying their beaks in front of the head and thrusting it into the protesting green victim from this position. After the beak is once in, protesting does no good on the part of the worm; it is done for.

Some clear night take your net and the small collecting boxes to some electric light. It will be a good idea to have some tall friend go with you or to take along something to stand on. Be careful not to injure the specimens caught in the net. There may be some valuable insects in the dancing swarm about the light. If it is a cold night, it is of little use to go. Watch the insects for a few minutes to see what you are likely to have in your net, and also to see how they behave. Test yourselves to see if you can distinguish members of any of the orders with which you have grown familiar; and whether you are able to determine how far some of them have been attracted by the light. Possibly the latter fact will not come out until you have your finds at closer range.

By dextrously sweeping the net through the air, and carefully separating into the collection boxes, many insects may be taken home for examination immediately, if one has a good light; or may be kept for daylight study. 
With the help of your instructor, and aided by good insect manuals, many of the insects found may be named. At least, you will be able to determine by the mouth parts what different sorts of insects are attracted by the light and fly toward it. Light has curious effects upon different animals; some are attracted; some are repelled. As between diffused light and a single point, some insects will be drawn toward the diffused light, while they are unaffected by the single point. How is it with these insects? How is it with yourself?

The corn or the wheat field, the region of the taller forage grasses, or sometimes the blue grass of the lawn may yield, close down to the roots or up a ways on the stem, numerous specimens of chinch bugs. Can you discover the adults? Dig down among the roots; can you discover them here? What is this stage you find under the surface of the ground? On what are they feeding? Can you find the beak? You may possibly discover short-winged and long-winged species, or all the individuals in a given area may have short wings. When disturbed do the insects fly or crawl? Have you seen them migrating? Catch and kill as many as possible.

In early midsummer, whenever that arrives for your locality, be on the watch for cicadas. The first cicada song should be the signal for the hunt. A hundred chances to one the singer will be "up a tree," and you will not be able to go after it. Be patient; the cicadas spend the immature stage below the ground surface; so in the orchard, or on the lawn, along the fences or hedge rows, where trees grow, watch the ground and you will probably be rewarded by finding a cicada moulting for the last time. In this condition the insect may easily be caught. You may discover some of the grayish, lumbering nymphs 
lagging across the sidewalk; and whenever you find one do not hesitate to catch it. After examining it, it is to be consigned to the killing bottle - a pest well gotten rid of. (Fig. 45.) When you seize the insect by its broad back, do not be frightened by the furious noise that it makes-. it is only noise, and not at all dangerous. Can you discover the "musical apparatus" on the under side of

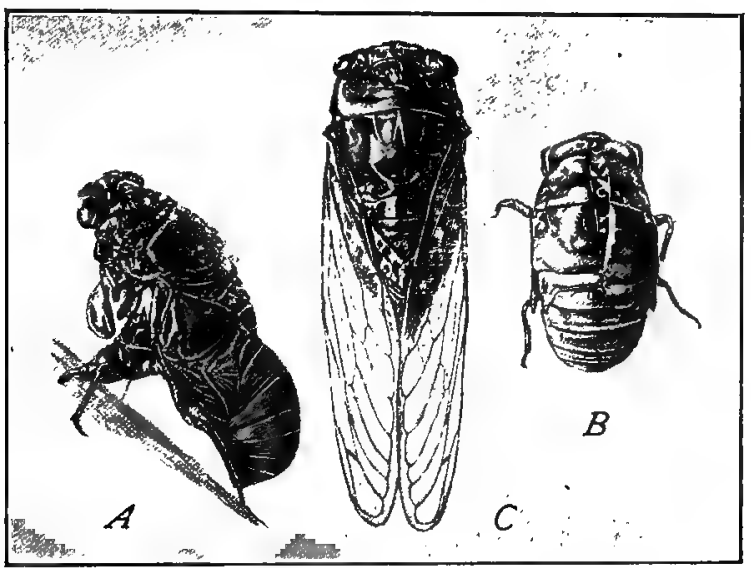

Frg. 45--Development of a cicada. Cicada tibicen. A, imago emerging from nymphal skin; $B$, the cast skin; $C$, imago. Natural size. (Folsom.)

the body? Are the wings half opaque or wholly membranous? Can you discover the beak? How does the cicada carry the beak? Are you able to find one of the insects feeding?

If in some green-house, or elsewhere, there are plants that are troubled with scale insects, an expedition may profitably be made to see the insects, or a branch of the plant afflicted may be secured for study. Examine the scale as it lies on the stem. Has it any means of defense? 
With a pin or a toothpick turn one of the scales over on to a glass slide and put it under the low power of the microscope, in good light from above. Has the insect any legs? Can you find the sucking beak? How was the insect fastened to the leaf? Are the young insects hatching from the eggs? If so, can you discover their eyes and legs?

There are many hemipters which may well be claimed for the insect cabinet. When such harmful hemipters are taken from the killing bottle the pin should be thrust through the thorax. A very valuable mount may be made from some group or family of bugs, where big bugs, little bugs, and middle-sized bugs are found feeding together. Pin them in a row, beginning with the smallest of the lot, and increasing toward the last pin, which should hold the adult insect, and may also bear the ticket. 


\section{HEMIPTERA.}

\section{CHARACTERISTICS.}

I. Body usually softer than the beetles'.

2. Wings, four, but the front pair usually thin and soft, and opaque only part way to the tip.

3. Wings overlapping on the back.

4. Mouth parts prolonged into a sucking beak which projects from the front of the head or is folded back on the breast under the body.

5. Wings absent in some sorts, but the mouth parts are still modified into the beak. 



\section{HEMIPTERA.}

These insects, along with the beetles, and, for that matter, nearly all the other insects except the butterflies and the moths, are called bugs, and these, alone, of all of them, are entitled to the name. The name of the order has reference to the peculiar make-up of the front wings. In the true hemipters, these have the base of the wingcovers thickened so as to be nearly opaque; while the hind wings are clear and transparent, or nearly so. (Fig. 46.)

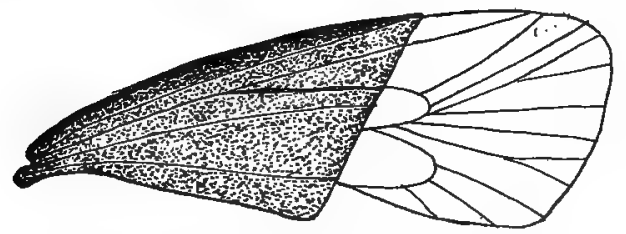

FIG. 46.--Front wing of an hemipter.

This is the order of the bugs, using the word in its true signification, and not including beetles, wasps, flies, or ants, nor any others of the insect kind, which we so frequently mean when we say "bugs."

The order may be divided into: (I) Parasitic, wingless forms with unsegmented sucking beak. Examples of these hemipters are the lice of the dog, horse, cattle, hog, or sheep kinds, and also the human louse. (2) Winged or wingless forms with the beak segmented; wings, when present, of the same texture throughout. Here are found the cicadas, the plant lice and scale insects, mealy bugs, leaf hoppers, and gall-forming aphids. (3) Winged insects 
108

with the basal half of the front wings thickened, all four wings lying on the back when not in use, with their tips overlapping; the sucking beak arises from the front of the head, and the body shows a more or less distinct neck. The last division is the division of the true bugs, that is,
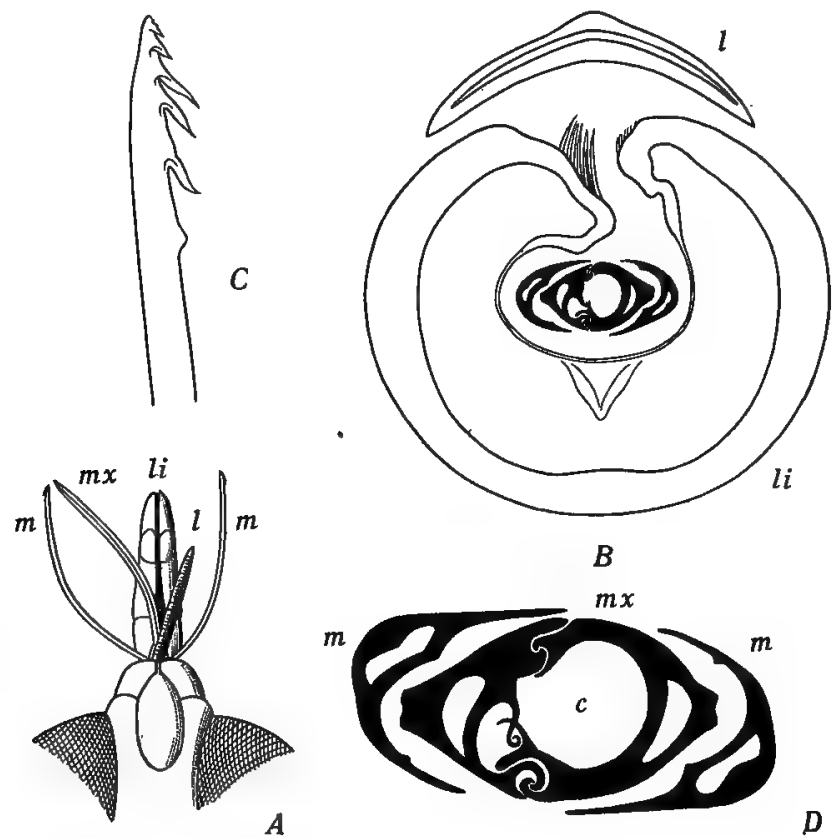

$A$

D

Fig. 47.-Mouth parts of an hemipteron, Benacus griseus. A, dorsal aspect $B$, transverse section; $C$, extremity of mandible; $D$, transverse section of mandibles and maxillæ; $c$, canal; $l$, labrum; $l i$, labium; $m$, mandible; $m x$, maxillæ. (Folsom.)

the bugs having the characteristics which distinguish the order from all the other orders of insects.

The insects of this order differ from both the beetles and the orthopters in the manner of getting their food. All of them suck the life fluids of either plants or animals. 
The mandibles and the maxillæ are formed into an effective piercing and sucking organ called the beak; and this is enclosed by the labium, which is in this order formed of two pieces, grooved on their inner edges, and fitting together around the stylets so as to form a tube or suction pump, by which the sap of the plant or the blood of the animal is pumped into the greedy maw of the blood-thirsty bug. (Fig. 47.) One predatory member of the order is fond of the green cabbage worm, and may be watched while it energetically pumps away the life blood of the unlucky worm, working the sharp stylets up and down inside the hole made by the labium.

Unlike the beetles, the hemipters pass through no pronounced changes on the way to adult size. Except the males of the scale insects, all of the order have incomplete metamorphosis, passing through the egg and the extended larval stage, which merges into the adult form by means of repeated moultings while the insect is eating and growing. The insect just hatched from the egg is a tiny bug, resembling its parents in form and food habits; but it has no wings, and its colors are often different from the adult colors.

Having the same sort of mouth parts, the young bugs have the same food preferences as do the adults, and hence the young are to be sought in the same places as the adults. The egg-laying process usually occupies some days; hence in any brood are to be found young bugs in many stages of development; from those just hatched, tiny, wingless individuals, to the winged adult, all sucking away at the pumpkin or cabbage leaf. Usually the predatory insect insists upon the right of discovery, and preempts its victim to the exclusion of other insects-a useful habit, as it rids us of many more injurious insects. 
The first division of the Hemiptera is the division of the disgusting parasites of many of the lower animals and also of man. These are all wingless insects having only small locomotor powers and living the whole life round, from the eggs to the adult, on the body of the host. The mouth parts are all modified to form a fleshy, sucking beak; the feet have only one claw, and this is usually bent at an angle which enables the pest to cling to the hair, wool, or clothing of the host. The eggs are usually glued to the hair or wool of the host, or deposited in creases of the clothing.

In the second division of the Hemiptera, come the scale insects, the pests of nurserymen and florists. The male, where this form is produced, is a winged individual; while the female possesses no wings, and during the greater part of her life, in most of the species, has no feet. These insects have remarkable powers for producing young, several broods being raised in a year, even by the outdoor sorts, while the indoor, green-house pests breed practically all the year round, taking advantage of the artificial culture which man unwillingly gives them. Various measures, such as fumigating and spraying, are used against them with varying degrees of success. Their most effective enemies are the ladybird beetles, mentioned in a previous order. These ladybirds are easily caught, and, their safety being a matter of so much moment to an agricultural community, the killing of them should be prevented by all means. So far as their bird enemies are concerned, the ladybirds have a fairly good weapon of defense in their secretion of a fluid which renders them very disagreeable in taste; they can afford to be so brightly colored because they taste so bad.

There is no defensive measure against the scale 
insects which should be neglected, the rapidity with which they breed, and the difficulty of killing all the individuals of any one brood, making them exceedingly hard to get rid of. The females of many of the scale insects in the adult stage secrete about themselves an impervious shell of waxy scales or a covering made of the juice of the wounded plant whose stems are furnishing them with food. These coverings increase the difficulty of treatment at this stage.

For infested plants in the green-house, or even for trees in the nursery, fumigation with hydrocyanic acid is recommended by those who have tried it. It certainly kills all individuals that have hatched from the egg. In the fumigation, a cloth covering large enough to envelop the plant or the tree is necessary. The fumigant is made by pouring water into commercial sulphuric acid and adding cyanid of potassium; the three substances to be in the proportion of ten ounces of the water to one ounce of the sulphuric acid to three ounces of potassium cyanid, made up in the quantity required, the amount given being sufficient to fumigate one hundred cubic feet of space. Dilute sulphuric acid, which is usually made up in the proportion of one to ten, if it can be bought, is better to use than to attempt the making of the mixture one's self. There is always a little danger attending the rapid mixture of sulphuric acid and water. If you make the mixture, take the precaution to pour the water in slowly. The fumes of the mixture acting on the cyanid of potassium are deadly poison; hence care must be taken not to breathe them; they are intended only for the scale insects! Have all other things in place before you pour the mixture on the potassium cyanid.

The division of the true bugs, or the Heteroptera, 
as they are called, includes twenty-six families, ten of which are aquatic in their life habits. Hence in any pool in the river or in the ponds, in the warm spring days, the observer will find large numbers of these true bugs, whose feeding habits should be studied while they are darting about the pond in the activities characteristic of their kind. The shore insects do some good as scavengers by eating drowned insects along the shore line of bodies of fresh and salt water. The water striders and the water boatmen are to be found in the ponds or pools, also the giant waterbug, the electric-light bug, so called because it may so often be found flying about the electric lights at night. Most of its life is spent in the water; it is only the adult insect which comes out into the air occasionally, and these expeditions seem to be made for the purposes of food-getting and seeking another pond, there to lay its eggs and thus distribute its kind. This insect is fiercely predaceous, and often does serious harm to animals much larger than itself, such as carp and gold-fish.

Here, also, may be found the water scorpions, dirty stick-like bugs, rather sluggish in their habits. They have a long respiratory tube which they lift up to the surface of the water as they lie in some shallow pool, and through which they take in a new supply of air. Hence they are really air-breathing insects, although they spend their life in the water. This is true of many of the aquatic bugs, and some of them are terrestrial in the adult stage. The back-swimmers, the toad bugs, the marsh treaders, and the shore bugs, all belong here, and they all have a slender piercing and sucking beak. The food of most of the aquatic hemipters consists of other forms of aquatic life, and if the insects thus serving as 
food are injurious, these bugs are to be reckoned among the beneficial hemipters. Many of them eat stems and leaves of aquatic plants.

Five of the sixteen terrestrial heteropterous families are predaceous, hence beneficial to man. Among them may be mentioned the assassin bug, the soldier bug, the damsel bug, the thread-legged bug, and the flower bug; two species of the last-named feed upon the chinch bug. All the remaining eleven families of the order feed upon plant juices, hence these are the reprobate bugs which give a bad name to the whole order, in the minds of many people. Here among these eleven families are to be found the squash bug, the chinch bug, the leaf bugs, the stink bugs, the shield-backed bugs, and the negro bugs - these latter are very small and very black bugs to be found on raspberry bushes and other fruits,

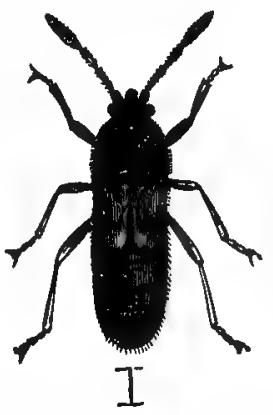

FIG. 48.-Short-winged chinch bug, Blissus leucopterus. (Howard, after Riley.) which they spoil for market by imparting a very disagreeable odor to them.

The chinch bug, that notorious pest of the farmers of the land, is one of these harmful hemipters. This insect and the hessian fly do, perhaps, more damage to growing crops than any other half dozen insects known. (Fig. 48.) Like all other hemipters, it has an effective sucking beak, and its larval period is largely spent just beneath the surface of the ground, where it feeds upon the roots of the plant whose leaves are to feed it later.

The first mention of the chinch bug dates from North Carolina in 1785 . To-day it is distributed over southern Africa, and from Europe to the sandy plains of Hungary. 
On the western continent it has the run of the two Americas from Panama to middle California on the western coast, and from Panama to about the latitude of Cape Breton on the east. Inland it has spread over a region from Texas to Manitoba. The states suffering worst from its ravages are Wisconsin, Nebraska, Iowa, Kansas, Illinois, Missouri, Indiana, North Carolina, and Virginia. According to accounts, it fed on native grasses originally, and often now uses them as a breeding host, migrating to cereal plants later. Of the cultivated crops upon which it feeds, it seems to prefer wheat and corn, millet, sorghum and broom corn; feeding also upon timothy, Bermuda grass, blue grass, crab grass, and, in the South, upon rice.

The eggs are laid on or near the surface of the ground, on the roots of grasses or grains. Howard reports eggs as having been found in the sheath of grass stems. The egg-laying occupies a period of ten days to three weeks; and the eggs hatch in an average time of two weeks. The adults reach maturity in from fifty-seven to sixty days from the time of hatching. The young larva or nymph is at first yellow, with an orange spot on the middle of the abdomen. After the first moult it turns a bright vermilion except the two segments at the base of the abdomen, which remain yellow. After the second moult the vermilion gradually gives place to the adult colors, dusky gray and black; while, at the same time, the wing pads increase in size. The adult has a rather oblong, somewhat hairy body; the elytra are white with a blackish spot on the side, midway of each elytron.

Its most important natural enemies among the insects are the soldier bug, the insidious flower bug, one of the ground beetles, lace-winged flies, and also spiders. Among 
birds it has quite a number of enemies-red-winged blackbirds, brown thrashers, house wrens, prairie chickens, meadow larks, and quails. Of all these, the quail is the most important enemy. The quail is protected by law; but there is no good and sufficient reason why this bird should be killed in the so-called legal season. North of Lat. $38^{\circ} \mathrm{N}$. the breeding season of the quail begins in May and extends as far as September; probably two broods are raised in the northern states and three in the southern. Why so valuable an ally of the farmers of the land should annually be killed off in such numbers by men is inexplainable, save on the ground that their slaughter is the gratification of an instinct which is savage at best, and probably a relic of the old days when man was a savage and had to conquer the animals about him in order to survive. If such enthusiasts would turn their attention to the fierce carnivorous animals, tigers, lynxes, catamounts, for example, instead of some small, weak, fluttering bird, perhaps with a nestful of young, it would be creditable to the man, kind to the bird, and beneficial to the human tribe in general.

Certain climatic conditions seem to check the spread of the chinch bug. Heavy rains, especially in May, the height of its breeding season, or a continuously cold, wet spring, impose quite effective restraints upon it.

Among the artificial, or perhaps one should say, the other natural enemies, are two tiny mould plants, similar to the moulds which attack our house flies in the autumn, leaving them a mere shell filled with the white thready growth of the plant. Certain bacteria are also present in the intestinal cæca. As early as 1865 , Dr. Shiner recorded the fact of finding large numbers of chinch bugs of all ages, dead upon native grasses and corn. He called it a 
disease, and mentioned the fact that the weather was wet, cloudy, and cool. Forbes' investigations began in 1892 . He proceeded on the theory of bacterial disease. He found that bacteria completely destroy the secreting glands of the tissue lining the delicate intestinal tract of the chinch bug. This leaves the intestinal tract filled with a mass of the bacteria together with a small intermixture of fat globules and a little detritus of nondescript sort. It is a well-known fact that moulds are saprophytes; that is, they grow on decaying matter. And here is the agency furnishing the exact condition favorable to the growth of the mould plants-this decaying intestinal matter. It remained for Snow of Kansas to make the practical application of the early knowledge along these lines. In a report made to the State Board of Agriculture, in 1887 , he urged this theory of chinch bug disease and its significance to the crop-growers. In 1889 , the first trial was made. There was much to learn about it; such as the fact that these bacteria flourish best in cool, wet weather, and that the fungous disease produced by the two moulds is a secondary enemy, and must be preceded by the bacteria. Hence clouds and rain, bacteria and moulds must work in conjunction, or the slaughter of chinch bugs will not be effective.

The insidious flower bug, mentioned as one of the enemies of the chinch bug, is also valuable from its habit of preying on other harmful insects. It was formerly called the false chinch bug, was often found associated with it, and looks considerably like it as to colors and markings, but has a much broader body from the head backward. Instead of assisting the chinch bug to pump the sap out of plants it turns the tables and destroys many of these pests: 
The soldier bug is yellowish as to body color; the legs and antennæ are banded with fine black bands. These insect enemies of the chinch bug are to be valued, especially when it is remembered that the pest belongs to a group of insects one of whose effective means of protection is a disagreeable odor which usually protects them from their enemies.

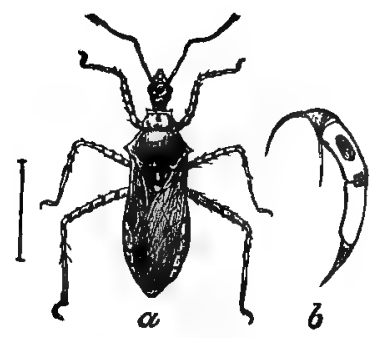

FIG. 49.

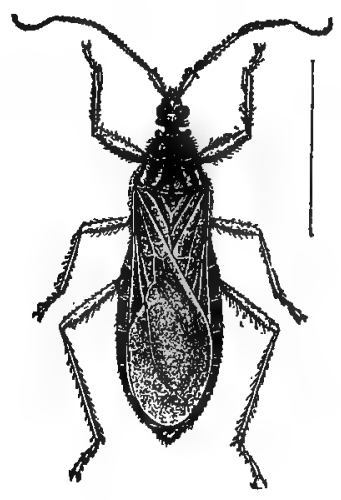

FIG. 50.

FIG, 49.-Soldier bug, Milyas cinetus. (Howard, after Riley.)

FIG. 50.-An assassin bug, Reduvius personatus. (Howard.)

The assassin bugs, as their name indicates, are predaceous, hence helpful to man. But one of these insects has a name less indicative of commendable habits; it is sometimes called the kissing bug in newspaper parlance, as it has the occasional habit of piercing the skin of human beings. In this case the saliva injected into the wound made by the stylets is, to say the least, irritating to the human victim if its effects are not more disagreeable. 
Some harmful hemipters and their bird enemies might be mentioned:

\section{Squash bugs}

Hawks

\section{Stink bugs}

House wrens

Song sparrows

Chinch bugs

Quails

Meadow larks

Prairie chickens

Kildeers

Scale insects

Downy woodpeckers Brown creepers

\section{Bark lice}

Hairy woodpeckers

Nuthatches

Chickadees

Brown creepers

\section{Seventeen-year cicadas}

Cranes

The order includes about five thousand species for North America alone; and yet it is a comparatively small order, the Coleoptera including more than eleven thousand species, and that order falls far behind the order of the flies in point of numbers. When the systematist says species, he means kinds; so there are more than five thousand kinds of bugs. 


\section{CHAPTER X. \\ FIELD WORK ON LEPIDOPTERA.}

An expedition for lepidopters should be made to the open meadows and fields some sunshiny afternoon, between two and four o'clock.

\section{Discover :}

What colors are represented in the lepidopters which you find in these places?

What are they seeking as food?

Are their habits of visiting flowers promiscuous, or constant as to a given food source?

Do they know an enemy when one approaches them?

Can you tell anything about how far a butterfly can see?

Are you able to see the synchronous wing action?

What is the manner of disposing of the wings when not in use, that is, when the insect is resting on some object?

Do butterflies and moths ever walk?

Do they see or smell their food?

Another expedition should be made early in the day, before the dew is off the grass, to some waste lot or the south side of hedge rows, or wherever the grass grows tall.

Can you discover whether butterflies sleep?

Are flowers fragrant at this time of day?

Is the dew on the insects as well as on the flowers? An expedition should be made to the woods early in the afternoon. 
Do you find butterflies? Moths?

Are they working in the shady depths of the woodland or in the fringe?

Do the colors of these insects differ from the colors of those you found in the expedition to the open fields?

Look on tree branches, bushes, or tall weeds, and even smaller plants for pupa cases. Look in the garden, or on the forest trees, on fruit trees, and bushes for larvæ. $\mathrm{Be}$ sure to discover what each caterpillar is eating. Bring home these caterpillars with sufficient food to last them for some time. If you do not know where to get any more of the same kind, take home plenty to last the larva for the rest of its larval life.

Once home, the plants must be freshened in water if they were not put into an air-tight box on being cut; and some sort of a place must be made in which to keep your "finds." You will find that your caterpillars will stay with you contentedly if they have the right kind of food and plenty of it, and are not so crowded that they frighten each other off.

A good crawlery for your caterpillars is a large pan with vertical sides. This will also hold water to keep the twigs and leaves fresh; and if you do not have too many different kinds, one pan will likely keep all of them. The pan must be cleaned each day; lift out the twigs, the caterpillars, and any leaves that you may have there as food, and return them after cleaning the pan. This pan is useful in another way; most caterpillars must have water to drink, and this will be supplied by the water in the pan. It is really interesting to see a caterpillar stop eating to drink up some water drop that it may have found.

Caterpillars moult frequently and rest occasionally 
during the day; but, when fully grown, will either spin a cocoon in some nook among the leaves or will go off into some secluded place and "pout" until you give them a box of earth, when they will disappear by burrowing beneath the soil; and that will be the last of them you will see for some days, weeks, or months, according to what kind of a caterpillar you have. The earth for this box should be sifted and should not be very dry. The top of the soil should be lightly sprinkled occasionally, and ought to be kept in some cool place, as cool as possible and still be above freezing. Some caterpillars spend the winter in such burrows where the temperature is much below that of the house. Even with all your care in keeping the box cool, the butterfly or the moth will usually appear before his outdoor brothers and sisters have stirred in their winter beds. The perfection of skill would be reached if you arranged to have some blooming plants ready for your moths and butterflies to feed on. Sweet alyssum or petunias might be tried.

Arrange matters so that you can stay in some flower garden from sundown till eight or nine o'clock, when the flowers are in full bloom and the moon is near the full.

As the twilight comes on, which flowers disappear first?

Which flowers can you still see just between dark and moon rise?

Can you discover any insects working during early twilight? Are they moths or butterflies?

Do any insects come after moon rise? What brought them? How do they find what they want?

As a general proposition, do moths and butterflies confer benefit or do they do harm? In the late summer, moths and butterflies may be secured for the collection 
box; by that time they will have completed their life work and death will soon come to them naturally.

In setting up a lepidopter, after making sure that it is dead, thrust the pin through the thorax, setting the insect well up toward the top of the pin; then set the pin with the insect on it in the trough of the drying-board, to such a depth that the wings lie on the sides of the board at a slight angle with the plane of the body, say $25^{\circ}$. Carefully spread the wings, front and hind wings on both sides of the body, in order to display the veins and color markings. If the trough is too wide to allow the weighting of the wings after they are stretched, put a piece of stiff paper or card board on the board under the wings and stretch the wings on this. Care must be taken not to break off the legs of the lepidopters, and the antennæ must also be carefully preserved. 


\section{LEPIDOPTERA.}

\section{CHARACTERISTICS.}

I. Four wings.

2. The wings generally clothed with scales; the different colors of the scales make regular patterns on the wing surface. There are a few clear-wings with the scales nearly absent.

3. Body densely clothed with hairs.

4. A sucking proboscis which is coiled under the head.

5. Mandibles almost indiscernible.

6. Butterflies have clubbed antennæ swollen at the ends.

7. Moths have antennæ of various forms but not clubbed.

8. Butterflies at rest fold their wings together above the back; while moths leave their wings extended when at rest. 



\section{LEPIDOPTERA.}

This is the order of the moths and the butterflies. Both of the divisions are characterized by the presence of scales on the front and hind wings and on the body as well. These scales are modified hairs; indeed, on some parts of the body of most members of the order, there are to be found hairs, either simple or branched, along with the scales. The color and arrangement of these scales and hairs are so constant that they constitute a basis of classification for many species of moths and butterflies. (Fig. 5r.) A very few exceptional species are wingless as to the females, and a few species with clear wings look very much like bees. But if one is fortunate enough to find one of the clear-wings when it has just come out of the pupal case, he will find its wings quite plentifully provided with scales; these readily wear off. Indeed, in any of the order, the old insect presents a bedraggled appearance, many of the beautiful scales having been worn off in its struggles with hard

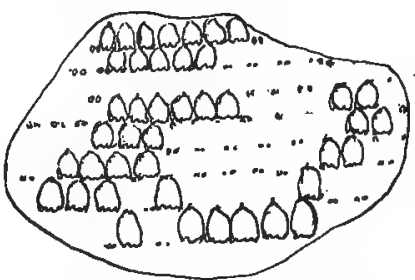

FIG. 51.-Portion of wing of lepidopter, showing scales and scale pits. winds or bird enemies, or perchance some cat or dog.chasing it. The venation of the wings is constant, and the modifications from the type are so slight that venation constitutes another basis of classification. (Fig. $5^{2} \mathrm{~A}$ and B.)

A characteristic which serves to separate this order from all other orders of insects is the highly modified con- 
dition of the mouth-parts. In most species of the order there is a well-developed proboscis. (Fig. 53.) This differs from the sucking beak of the hemipters structurally, and it is also unlike it in the manner in which it is used.

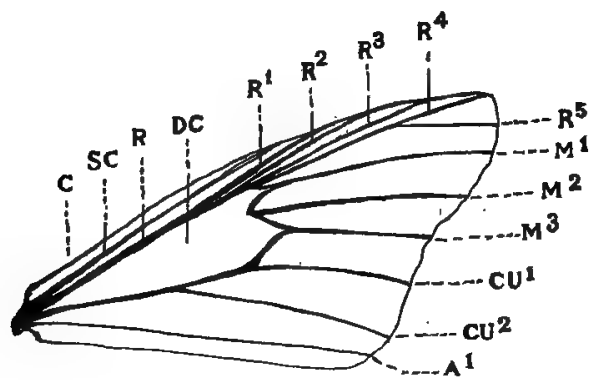

FIG. 52, A.-Front wing of monarch butterfly, showing veins. C, costal; $\mathrm{SC}$, subcostal; $\mathrm{R}$, radius; $\mathrm{DC}$, discal cell; $\mathrm{R}, i, 2,3,4,5$, branches of radius; $\mathrm{M}, \mathrm{I}, 2,3$, branches of median vein; CU, cubitus; $\mathrm{A}$, anal vein.

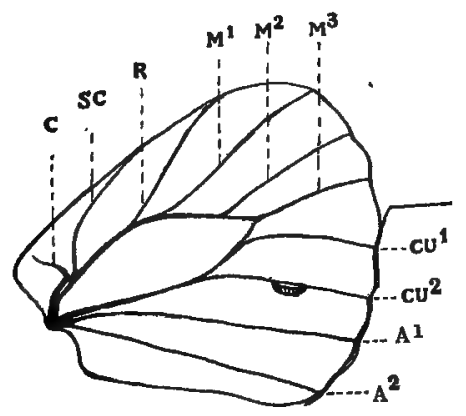

FIG. 52, B.-Hind wing of monarch butterfly, showing veins; lettering same as for front wing. The scent pocket is shown on the $\mathrm{Cu}^{2}$ vein.

The beak of the hemipter is a stiff organ, and when not in use, is usually folded once sharply under the head, against the thorax, by means of the hinge-like articulation just where the beak joins the head. Not only is this true, 
but the hemipter must first pierce the epidermis of its victim before it can avail itself of the store of liquid food; while the sucking proboscis of the lepidopter is coiled neatly under the head when not in use, and when getting its food, the butterfly uncoils its proboscis, puts it far enough down into the flower cup to reach the nectar, and then drinks much as if one were sipping lemonade through a straw. This proboscis consists of the greatlymodified maxillæ applied to each other so that the two fit tightly along a common groove.

(Fig. 53.) This feeding organ, in some of the sphinx moths, projects four or five inches in front of the head, when it is uncoiled in the act of sucking the nectar from some deep flower cup. (Fig. 54.) In other species of lepidopters it is only a fraction of an inch long.

If you watch a sphinx moth at a trumpet creeper blossom or a moon flower, you will see it

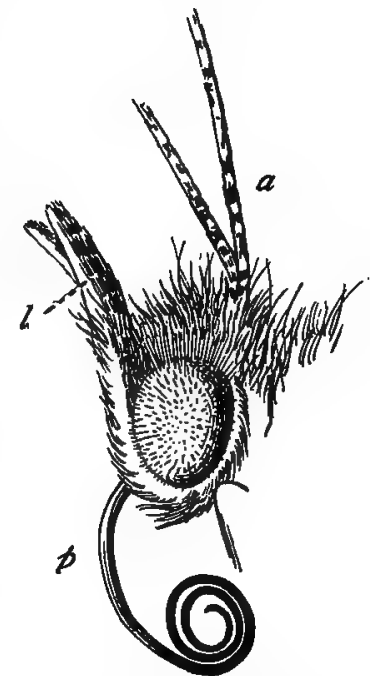

Fig. 53.- Head of a butterfly, Vanessa. Labial palpus; $p, a$, antennæ; $l$, proboscis. (Folsom.) uncoil this proboscis and lower it into the flower cup, (Fig. 55) all the time humming busily. These sphinx moths are often mistaken for humming birds. The other mouth parts are, in the great majority of lepidopters, reduced to mere rudiments. The significance of this fact is apparent when the butterfly's manner of food-getting is considered.

Other instincts than taste are determinative in the butterfly's choice of food. Apparently, sight and smell 
play a large part in the search for food. It would seem that it would be a decided disadvantage, if not a positive

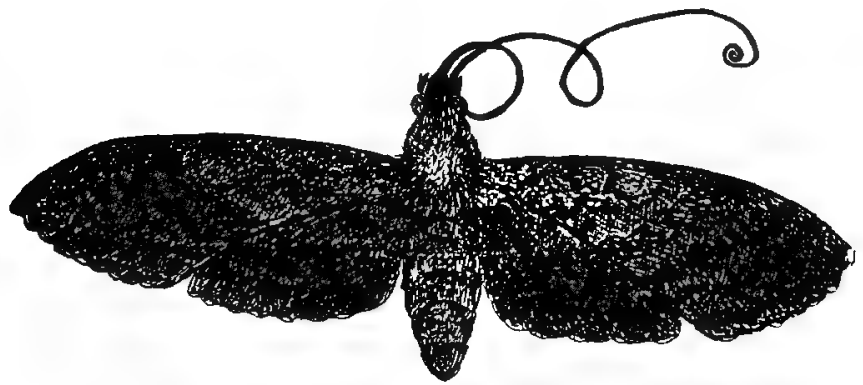

FIG. 54--Adult of tomato worm, showing sucking proboscis uncoiled.

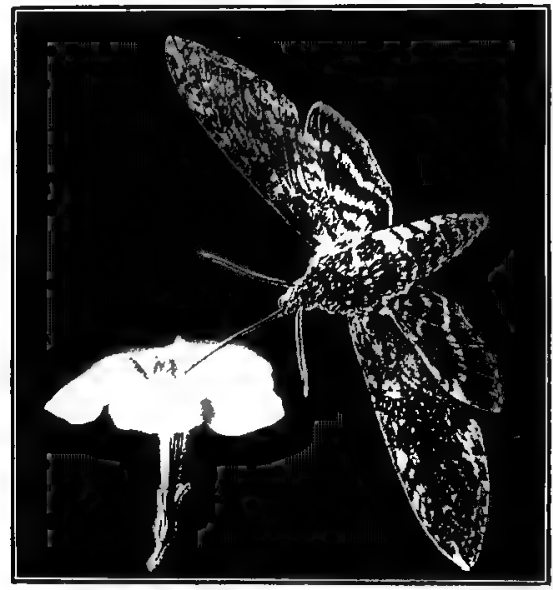

Fig. 55.-A sphinx moth. Phlegethontius sexta visiting flower of Petunia. (Reduced. Folsom.)

danger, if the butterfly were compelled to wait upon a taste decision until the liquid food had traversed the 
length of the sucking tube, unless it were true that the taste cells are located at the entrance to the proboscis, or somewhere near the entrance; and the microscopic examination of the proboscis seems not to warrant this assertion.

In one of the representative families of the order the mouth parts are as well developed as they are in the beetles; but these minute moths are exceptions among the Lepidoptera. They are extremely small insects, being only about one-fifth of an inch long; the front and hind wings are about equal in size and curiously veined. Not only is this true, but the mode of fastening the wings together on each side of the body is different from the other lepidopters. This latter peculiarity is shared by the Swifts or Hepialidæ. These latter moths are larger than the ones first mentioned, the Eriocephalas, being from an inch to two inches long. Their wings are also very nearly equal in size and are similar to the Eriocephala wing in venation. The peculiar method of fastening the front and the hind wing together, shared by these two sorts of moths, is a small stiff hook or chitin rib projecting backward from the front wing and fitting under the costal margin of the hind wing, while the rest of the

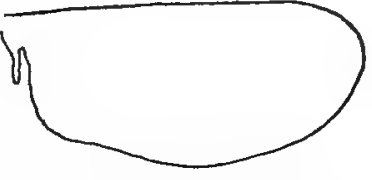

FIG. 56.-Front wing of a jugate moth, showing the jugum. wing fits over the costal margin of the hind wing.

(Fig. 56.) This projection is called a jugum, meaning a yoke; and hence these members of the Lepidoptera are called the Jugatæ.

These moths are interesting from another point of view. They are undoubtedly the most primitive living lepidopters, and may be regarded as the remnants of what, at an earlier geological period, must have been a much 
larger tribe of insects. Differentiation of cells, tissues, or organs is held by the scientist to mark an upward step in the continuous stream of life. The conspicuous similarity of the wings of these jugate moths thus indicates their low position among the Lepidoptera; this is all the more apparent when one becomes familiar with the immense number of differentiations along just this line, which are found in the other great division of the order-

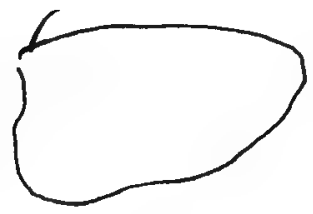

Fig. 57 A.

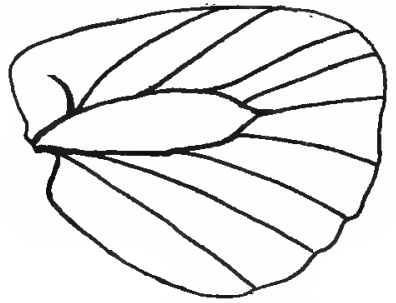

Fig. 57 B.

FIG. 57, A.-Hind wing of a frenate lepidopter, showing the frenulum.

FIG. 57, B.-Hind wing of a frenate lepidopter, showing wing angle, serving as the frenulum substitute.

the Frenatæ, and not only among the lepidopters but among the other orders of insects. (Fig. 57, A and B.) Among the beetles, the grasshoppers, and the crickets, as well as the bugs, the wings are so far differentiated as to make the hind wings bear the burden of flight, while the front wings are reduced to wing-covers or elytra as they are called. But in the bees and the wasps the front wings are the main flight pair. In the dragon flies the two pairs of wings share equally in the act of flying, besides acting independently. In the flies the hind pair of wings are represented only by stumps of wings, remains of what in an earlier age in the earth's history may have been an effective pair of wings performing their full share of the 
labor of flight. In harmony with this view, the points of structure as well as of metamorphosis lead our principal investigators to place the bees and the wasps higher than the grasshoppers and the crickets, and the flies at the head of the insect orders.

Another law which seems to find exemplification here - the lowest individual in any class repeats the life history of the individuals below it and anticipates the new features of the individuals above it. According to this law, we should find that the jugate moths have related forms among the insects below the Lepidoptera; and so we do find that some of these moths have the same kind of mouth parts as have the grasshoppers and the beetles, and the same mode of fastening the wings together as have the caddis flies, curious insects which spend their larval period in the water and have a short adult period with probably little aim or accomplishment beyond the production of their progeny. And on the other hand, these primitive jugate moths have the scaly wings of the more highly differentiated and typical lepidopters.

The Lepidoptera all reproduce their kind by complete metamorphosis, all of them passing from the egg to the larva, then to the pupa, then to the adult stage. The eggs are not smooth-coated as are the eggs of most other insects, but always have some fine sculpturing over the surface. The larvæ are the familiar caterpillars of the garden or the field. The pupæ are a little less familiar, but the observer surely has seen some of the curious, mummy-like cases, big and little, hung up in all sorts of queer places, waiting for the great change from pupa to butterfly or moth.

Birds are the natural enemies of insects, and lepidopters are easier to catch in the caterpillar stage than in the 
adult form; nevertheless these caterpillars, sluggish as they are, are not without means of defense. For any living organism, the natural thing is to continue to live; hence, we find that all activities of existing life forms have the general trend toward the preservation of the individual; though all may not be successful in every case. We must remember that the struggle for existence is not between the species and the conditions that surround it, but between the individual and those conditions, as it faces alone the manifold influences which may mean persistence through adaptive response, or may present the fatal alternative of death through the possibility of non-adjustment to conditions. The hairy caterpillars are an uncomfortable mouthful for most birds; though it often happens that a specially meaty caterpillar is whipped clean of the objectionable hairs by some diligent bird who is likewise struggling for existence-dinner in this case. The brilliantly-colored caterpillars are generally let alone by birds, and it is known for some of them at least, that the brilliant coloration is accompanied by some poisonous substance or acrid taste, and hence they are not good eating. Many of the larvæ have the same body colors as the things they feed on, and so pass unnoticed in many cases.

The larvæ are provided with biting mouth parts, and all are fruit- or leaf-eaters; this places the members of this order among the non-beneficial insects so far as their larva are concerned, but it is only in the larval stage that they are troublesome. In the pupal stage the insect eats little or nothing, only such food as the greedy larva has provided for it; while in the adult stage, the general usefulness of the moths and the butterflies to the farmer and the fruit-grower can hardly he overestimated. 
Besides this benefit as pollen distributors, the moth known as the Chinese silkworm moth, in its larval stage, furnishes the raw material for the silk of commerce.

Of course, the larvæ do not all eat plants upon which man depends. Many of them eat plants for which man does not care at all, or plants which are actually injurious so far as man is concerned; but the order has the unenviable reputation of being more nearly uniformly injurious in its larval stage than any other order.

Some of the larvæ that are commonly found are the larva of the sphinx moths, such as the penman, the tomato worm, the tobacco worm; and also the regal moth, the luna moth, the tent caterpillars, the handmaid moths, the black swallow-tail, the well-known cabbage butterflies, the monarch butterfly, the measuring worms, the plump greasy caterpillars called cutworms, and the Noctuids, moths that often fly into our houses after night, attracted by the light. Taking these in their order:

Penmarked Sphinx (larva).-Greenish- or bluishwhite above, and on the sides of the body there are seven yellow stripes placed obliquely and bordered above with a dark green stripe. When disturbed, it throws up the front end of the body in a threatening attitude; this last fact is common to many of the sphinxes.

Tomato Worm.-Much resembles the preceding larva; is usually green, but some individual specimens may be brownish and even reddish-brown. Its pupa is often found and may be recognized by the curious handle that curves backward and under the brown body case.

Tobacco Worm.-Much the same as the larva just described; the larvæ are very similar but the adults are distinguishable. 
The Regal Moth (larva).-This is the largest larva that we have in the United States, measuring from four to five and a half inches in length. It may be distinguished from all other caterpillars by the very long spines with which it is armed, but which are "not loaded." They are harmless but usually serve their purpose by frightening off credulous birds.

Luna Moth (larva).-Pale bluish-green with a much lighter head, usually white in most specimens. On the back are small purplish or reddish warty protuberances, about six to each abdominal segment; in addition there is a pale yellowish line along each side of the body.

Tent Caterpillars.-Social larvæ, never feeding alone, and the tribe generally making a web in which the young larvæ live; some species of them come out of this web to feed, returning to it at night, or whenever not feeding. Others live in the web for the entire larval period; and this they make provision for by spinning a web about the branch which they wish to devour, the completed tent often measuring more than a foot in length. The apple tree tent caterpillar is black, at least very dark, with white stripes along the back, and with yellow and blue spots. The forest tree tent caterpillar is larger than the apple tree pest, and usually has less of blue on its body, though they seem sometimes indistinguishable except by size.

Handmaid Moth (larva).-Often called yellow-necked appletree caterpillar; reddish-black with bright yellow stripes; many scores of the caterpillars in a wriggling mass. Each caterpillar has the habit of jerking the front and the hind end of its body up and down, probably to frighten off any waiting enemy. It is a well-known fact that the Tachina flies appreciate a juicy find of these worms, 
and with them the threatening is unavailing, for the Tachinas usually succeed in laying their eggs in the bodies of the protesting worms, where the young Tachinas soon proceed to use up the caterpillars to the satisfaction of every one except the caterpillars.

Black .Swallow-tail (larva).-A dark green worm with many black rings and bright yellow spots; two yellow horns on the segments of the body just behind the head are protruded if the caterpillar is disturbed, a sickening odor coming off as the result of the disturbance.

Cabbage Worms.- Slender green worms covered with very fine soft hairs, and usually with some pale yellow lines about the body. According to Comstock, the moth produces three broods in the middle latitudes of the United States. The effective work against it, then, would have to be done before the cabbages head in the spring. He gives pyrethrum powder and also kerosene emulsion as effective treatments of this really serious pest.

Monarch Butterfly (larva).-The larvæ are often called tiger caterpillars, greenish-white worms with shining black bands about the body from head to tip of abdomen. It grows rapidly, and turns into the familiar golden-brown pupa hung by its big tail-end to some leaf or twig, the pupa showing green and gold inside it.

Measuring Worms. - The familiar loopers that children are not usually afraid of. They have a curious habit of standing up on their hind legs to "view the landscape o'er," swaying the body from side to side as if looking for a good place to eat next. They are probably attempting to frighten off any possible enemy by their startling movements. Another device they have, if the first does not work, is to drop suddenly off the branch, 
and you think the poor fellow certainly has killed himself; but you may discover later on that he is swinging craftily at the end of a silken web which he spun for safety when you surprised him. As if these were not enough devices for one worm, if he is at all warned of your coming or if the cuckoo says anything before she gets near enough to see him, he will throw up the forward end of his body, sticking it straight out into the air, stiff and motionless, and the bird often passes this new kind of twig by. But justice sometimes has her due, and the villain is eaten after all his schemes have failed.

Cutworms.-The pests which, in addition to eating a goodly share of our field and garden crops, also cut off plants at the surface of the ground, thus destroying much more than they can eat. The larvæ on hatching out either eat near the surface of the ground upon which the egg was laid, or else crawl to the branches. of some tree to feed during the day, coming back to the ground burrow to spend the night in safety. They are at first minute worms, but soon grow larger and look greasy and plump, and are dark brown with lighter longitudinal lines. According to Comstock, the time and the way to cateh the groundfeeding worms is early in the morning or late the previous night by making holes in the ground close to the feedingplaces. The worms will crawl into these holes to keep warm or to hide as it grows light, and will be unable to crawl out again if the sides of the holes are smooth. The tree-feeders can be caught by spreading a sheet under the the tree and shaking the worms off, when they can be readily disposed of.

Some bird enemies of the harmful Lepidoptera deserve mention here: 
Forest and apple tree tent caterpillars.

Black-billed and yellow-billed cuckoos

Large caterpillars of all sorts.

Hawks

Hairy and spiny caterpillars generally.

The two cuckoos, black-billed and yellow-billed

Blue jays Catbirds

Robins Bluebirds

Gypsy moth caterpillars.

Yellow-billed and black-billed cuckoos

Robins

Baltimore orioles

Blue jays

Catbirds

Vireos

Chickadees

Chippies

Crows

\section{Smooth caterpillars.}

Brown thrashers

Sparrows, many of them

House wrens

English sparrows

The two cuckoos

\section{Cutworms.}

House wrens

Blackbirds

Sparrows, many of them Screech owls

English sparrows

Meadow larks

Quails

Robins

\section{Cankerworms.}

Chickadees

House wrens

Robins

Baltimore orioles

Catbirds

Summer yellowbirds

Brown thrashers

Bluebirds

\section{Army worms.}

Quails

Nearly the whole sparrow family. 
The Lepidoptera are widely distributed over the earth's surface, some of them being found within the Arctic circle, while others have the whole tropic range. According to Kellogg, Vanessa cardui, the Cosmopolitan, is found in every one of the continents outside the polar circles. Some of the other species of butterflies are found high up on mountains, near the timber line. Even the snow flowers of the Alps have their insect visitors. 


\section{CHAPTER XI.}

\section{FIELD WORK ON HYMENOPTERA.}

Various lines of investigation have already been suggested in the discussion of the order as a whole. If you are near an apiary in charge of some old bee-keeper, the best thing that can be done is to visit him and ask permission to go about with him while he tends his bees. Then, if you are wise in your questions and economical of his time, you may be able to induce him to talk of his bees and possibly to show you some of the brood combs with worker, drone, and queen cells. Stand still for at least five minutes and watch the bees coming and going; note their manner of flight, whether it is direct, or wavering and uncertain. How far off can you see them coming home? Must their sense of the direction of home from the last flower visited, been stronger than yours would have been? Do you believe that it is sight alone that guides the home-coming?

Walk out a little way to where the flowers that are being visited are growing. Take your reading glass and turn it on some bee found in a flower cluster. She will not notice you and you will have a chance to see how she does it. Remember that you are looking at one of the domesticated animals that have lived with man so long that they are not fearful of his presence when on flower business.

For observation of the bees in the school-room, a rather narrow hive box may be provided. Get some carpenter to make it; or there may be some ingenious 
boy in the high school or the grades who may be able himself to make a frame with glass sides and wooden ends with a slit low down in one end for the in-going and outcoming of the bees. Stand the hive on a shelf or a table pushed close to the window. Raise the window a little and put under the sash a thin strip of lumber as wide as the window opening and with a slit cut in it, so as to be just opposite the opening into the hive when this is done you can either push the hive close up to the window or leave it a little 'way out. If the latter, lay down two strips of wood to reach from the hive entrance to the opening in the window strip and cover these with a piece of glass, so that when you so wish you may see the bees as they pass in and out. It is best to keep this covered except when you wish to learn something of their doings, as bees do not like to be watched at their work; that is, you must not "keep tab" on them too closely.

In the study of ants the very best thing to do is to find an ant hill and dig down under the surface, a little at a time. If you do not know how, any small boy will tell you. One way, possibly, in addition to what he will tell you, is to make an attempt at a vertical section of the ant hill by digging carefully down to one side of the center so as to discover all that one may by so doingapproaching carefully the center of the hill. When you have dug away most of the earth up to this middle line and have found how deep the nest goes down, then with a spade or a large, sharp knife cut down from the exit tube, straight down to the bottom. This will be likely to cut open a number of the chambers as well as some of the galleries and show a number of facts concerning the use of the chambers, the modes of ant activity, and their behavior under disturbing circumstances. When a par- 
ticularly good view of a gallery, or room, and the galleries leading from it is obtained, make a picture of it. Do you find ants going both ways in some of the passages? Look for eggs, larvæ, and pupæ; and also discover the granaries if possible. You may know them by the seeds and other vegetable matter stored in them. Do you find any insects in the granaries that might be serving as food? Do any of the ants exhibit any care for the young when you disturb the nest? Is this care evidently the care for some particular ones among the immature ants, or is it care for the welfare of the colony as a whole? It will be quite a triumph if you are able to find any of the mothers of the colony. The ant mother is larger and thicker-bodied than are either the male ants or the female workers; besides, when you have a nest under examination, the males will not be likely to be living, as you know that the males do not as a rule live long beyond the starting of the ant home.

Sir John Lubbock, the eminent English student of insects, and especially of ants, bees, and wasps, gives instructions as to how to arrange a nest for ants so that their proceedings can be watched for one's self. He says: "After trying various plans, I found the most convenient plan was to keep them in nests çonsisting of two plates of common window glass about ten inches square, and at a distance apart of from one-tenth to one-fourth of an inch (in fact, just sufficiently deep to allow the ants freedom of motion), with slips of wood around the edges, the intermediate space being filled up with fine earth. If the interval between the glass plates was too great the ants were partly hidden by the earth, but when the distance between the glass plates was properly regulated with reference to the size of the ants they were open to 
close observation, and had no opportunity to conceal themselves. Ants, however, very much dislike light in their nests, probably because it makes them think themselves insecure, and I always therefore kept the nests covered over, except when under actual examination. I found it convenient to have one side of the nest formed by a loose slip of wood, and at one corner I left a small door. These glass nests I either kept in shallow boxes with loose glass covers resting on baize, which admitted enough air, and yet was impervious to the ants, or on stands surrounded either with water or with fur with the hairs pointing downward. Some of these nests I arranged on stands, as shown in the figure. A A is an upright post fixed on a base B B. C C is a square platform of wood around which runs a ditch of water. Above are six nests, D, each lying on a platform, E, which could be turned for facility of observation, as shown in the dotted lines $\mathrm{D}^{\prime}$ and $\mathrm{E}^{\prime}$. Thus the ants had considerable range, as they could wander as far as the water ditch. The object of having the platform $\mathrm{C} \mathrm{C}$ larger than the supports of the nest was that if the ants fell, as often happened, they were within the water boundary, and were able to return home. This plan answered fairly well and saved space, but it did not quite fulfill my hopes, as the ants were so pugnacious that I was obliged to be very careful which nests were placed on the same stand. (Fig. 58.)

"Of course it was impossible to force the ants into these glass nests. On the other hand, when once the right way is known it is easy to induce them to go in. When I wished to start a new nest I dug one up and brought home the ants, earth, etc., all together. I then put them over one of my artificial nests on one of the platforms surrounded by a moat of water. Gradually 
the outer earth dried up, while that between the two plates of glass, being protected from evaporation, retained its moisture. Under these circumstances the ants found it more suitable to their requirements, and gradually deserted the drier mould outside, which I removed by degrees.

"Even between the two plates of glass the earth gradually dried up, and I had to supply artificial rain from time to time."

A bumblebee's nest ought by all means to be discovered if it is a possible thing to do so. If a bee of this sort is found on a flower, occasionally one is fortunate enough to be able to trace it to its home

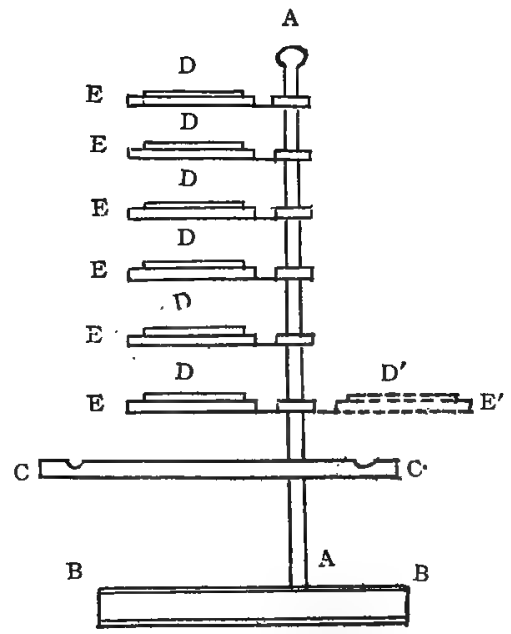

FIG. 58.-Ants' artificial nest.

(After Lubbock.)

nest. Especially is this true if you sight the bumblebee late in the afternoon, when she is making her last trip for the day. While you have the bumblebee under observation, discover whether the two sorts of bees, honey and bumble, like the same flowers. Do they seem to be equally burdened with the responsibilities of life?

Do you regard the life where the bumblebee mother works for the good of her own family and that alone, as beneficial with respect to life as a whole with its varied relationships of many kinds of animals of various degrees of efficiency, as is the life of the community bees, where each individual contributes cheerfully and efficiently 
to the output of work of the whole community? This is much like a similar question which might be put concerning our own effectiveness in the world. No one can do his best for others if he keeps in a corner by himself and refuses to help right cheerfully in the work of the big, busy world.

Wasps are more difficult to study on account of their irritability and their effective stings. Still, if you can find a small nest of a paper wasp, watch till you are sure that the wasp mother is not at home; then detach it from its fastenings and put it into a box which has previously had a square of wire netting set into the lid. If the lid is pasteboard, cut out a piece and sew in the netting; if the lid is wooden, saw out a piece and tack on the netting. This will enable you to see what is going on in the nest. Until some adults have emerged, you may examine the nest freely. You may find some of the cells open; this means that the eggs formerly in those cells have developed into adults which have gnawed their way out into the outer world. If there are some cells still smoothly capped, play wasp on one of them by carefully cutting the cap around its edge, leaving a small strip for a hinge. Raise this lid and look inside. If there is an egg, notice what food is left beside it. If it is a larva, notice its appearance and how it eats. Does the paper wasp mother go back repeatedly to feed her young larva? If it is a pupa, lift it out carefully and examine it on all sides to see how far the adult organs are developed. By watching the place where the nest hung you may be able to discover and watch the behavior of the wasp mother when she comes back and finds her nest gone, and what she does after the discovery.

Any galls found on weeds, bushes, or trees are interesting for study. There are many insects that form galls: mites, moths, gnats, and some small.beetles, as well 
as gallflies. The green galls, if closed, are most probably made by gallflies; besides this, when you cut them open, if the gall is due to a gallfly, there will be found inside nothing save the immature larval or pupal hymenopterous gallfy; while in galls made by some of the other gall-forming agents, it is the mother that enters the gall and rears her young within its increasing structure, and there will be found the opening by which the escape of the insect has been made.

Suggestions for the study of the ichneumons may be found in the discussion of the big Thalessa and the Pigeon Horntail. If a caterpillar outwardly in good condition be found dead on a leaf, pick off the leaf with the caterpillar on it, and store it in some box with a good lid; put a label on the lid and also on the box so that it may not be lost. Look often at the caterpillar for developments. If the parasitic insects have not already escaped you will be able to trace the life history of the parasites from the larvæ, which will appear, possibly, beyond the body wall of the caterpillar when they have attained their larval maturity and go through the pupal transformation. And some day you may find some tiny winged creatures flying about in the box when you open it. When these do appear they should be given their liberty out of doors to repeat the beneficial work of their kind. Whenever you have learned to know a harmful insect, miss no opportunity to kill it; in so doing you destroy not only that insect, but also all of its descendants. When you learn to know a beneficial insect, and this may mean one or more of the enemies of the first sort, be sure that neither you nor anyone else harms it; you will thus be able to avail yourself of the good done by it and by all of its descendants left unharmed. 



\section{HYMENOPTERA.}

\section{CHARACTERISTICS.}

x. Four membranous wings, bare of scales.

\section{Bees.}

Body thick-hairy.

Legs usually thickly clothed with hairs.

Wasps.

Body smooth, constricted at front of abdomen, or pedunculate.

\section{Ants.}

Body smooth, not pedunculate, but one of the abdominal segments is expanded to form a scale or button-like knot next to the thorax.

\section{Ichneumon flies.}

Abdomen curved and, in some of the smaller ichneumons, pedunculate.

Thalessa has three long hairs (they may look as if they were one) at the end of the abdomen.

\section{Sawflies.}

Head and thorax wide where they join the abdomen; the female bears a saw-like organ at the end of the abdomen.

\section{Horntails.}

Head and thorax wide, and abdomen broad and usually cylindrical; abdomen bears a spinelike organ; insects large.

\section{Gallflies.}

Abdomen compressed and pedunculate by the first abdominal segment; the second and third abdominal segments much larger than the other segments; insects small. 



\section{HYMENOPTERA.}

This is the order of the sawflies, the gallflies, the ichneumon flies, the horntails, the wasps, the bees, and the ants.

Among the members of this order are to be found the wonderful examples of community life which are not equaled elsewhere in the animal kingdom. And yet, while the community life of the social bees, ants, and wasps is certainly matter for wonder, the life of the solitary wasps and bees is not less wonderful in its wealth of economy, scheme, and device.

The order furnishes also the most interesting examples of parasitism in the animal kingdom. According to Fiske, the American tent caterpillar is liable to be parasitized by no fewer than twelve species of Hymenoptera. Six of these primary parasites may be parasitized by secondary parasites, also hymenopters. Four of the secondary parasites are in turn parasitized by tertiary parasites; and one of these tertiary parasites may be parasitized by an hymenopterous parasite of the fourth rank. Not much chance for the tent caterpillar in the midst of all this!

\footnotetext{
"Big fleas have little fleas

Upon their backs to bite 'em;

And these in turn have lesser fleas,

And so on, ad infinitum."
}

All members of the order have four clear, membranous wings destitute of scales. The front wings are larger than the hind wings and bear the brunt of the flight activities; 
and all four wings are provided with comparatively few branched veins.

You may have found caterpillars with their bodies quite thickly set with tiny white silken cocoons. These cocoons mark the third life stage in the life of some parasitic hymenopter, usually one of the ichneumon flies, which laid her eggs on the body of this caterpillar, and the greedy larvæ hatching from the eggs, bore through the skin of the host, and make many a meal off the protesting caterpillar, which finds it difficult to eat enough for itself and for all its uninvited guests also. The caterpillar may still be crawing about, feebly trying to find a juicy leaf and perhaps wondering why it feels so queer inside. But more likely it is just dead or dying, though some of them do manage to pupate in the face of such enormous odds. The mother ichneumon usually lays her eggs at or near the end of the caterpillar stage, and the fly has an unusually short period of immaturity.

The effectiveness of these parasites as aids to man, as well as of all parasites in general, depends upon their not being parasitized themselves, and also upon their not becoming so numerous as to eat up all the available caterpillars, or other hosts, within reach. If the ichneumon should do the latter, the succeeding season would witness a decided decrease in its own numbers, while the few remaining caterpillars would have a chance to increase.

Another of the ichneumon flies, the big Thalessa, is an interesting as well as a decidedly beneficial insect. The Pigeon Horntail is accustomed to boring into trunks of box elder, maple, or sycamore to lay its eggs. The larva hatching from the egg, eats or tunnels its way into the tree through the bark, and then turns downward along the inner wood of the tree, eating as it goes. It then pupates, 
and at the expiration of its pupal stage, intends to gnaw its way out to freedom, air, and sunshine; there to repeat the life cycle of its parents. But the big Thalessa seems to know where to find this fat, juicy, horntail grub, and she stops above where it is lying, deep down under the bark of the tree, throws her long ovipositor in a wide loop over her back, downward into the tree trunk, and begins

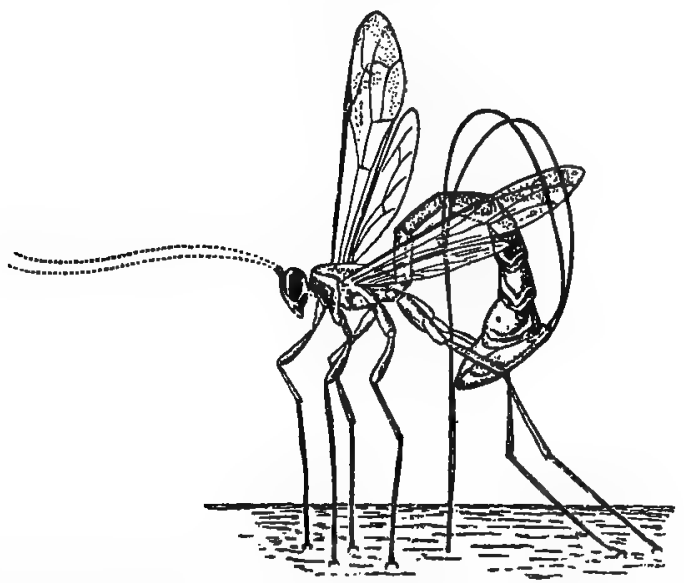

FIG. 59.-Oviposition of Thalessa lunator. (Natual size. Folsom, after Riley.)

boring straight down. How the mother ichneumon knows the horntail grub is under the bark cannot be determined; it is the manifestation of a marvelous power to locate that which cannot be seen. You and I might find the horntail tunnel in the outer bark, but we should be unable to tell which way the larva had turned on its way inward. (Fig. 6o.) The writer found in the summer of I 908 , four of these horntails unsuspectingly drilling into a box elder trunk; while around on the other side of the same tree were two of the Thalessas, also engaged in drilling (but not so unsuspectingly), providing for the wants of 
the young ichneumons, whose one mission in life would be to dispose of at least one young horntail apiece.

All members of the order have four clear, membranous wings, destitute of scales. The front wings are larger than the hind wings and bear the brunt of the flight activities. In the butterflies and the moths, the wings on each side of the body are fastened together either by a hook, by bristles, or by a pronounced curve of the front

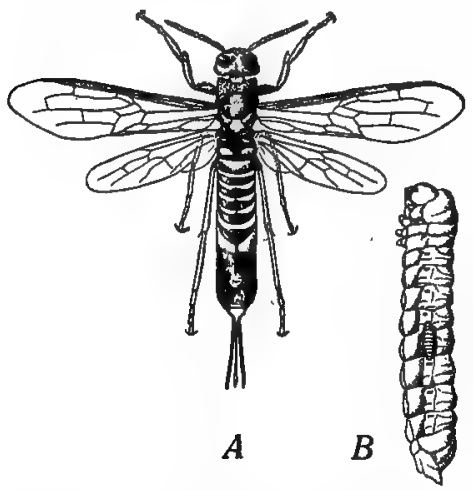

Fig. 60.-The pigeon horntail, Tremex columba. A, imago; $\mathrm{B}$, larva (with parasitic larva of Thalessa attached). (Natural size. Folsom, after Riley.) border of the hind wing. The beetles, the grasshoppers, and the bugs use only one pair of wings for flying, hence do not need to provide for the interaction of the wings. But in the hymenopters we come again to insects with four wings, all used for flight; and some means of synchronous action is necessary. If a honey-bee's wings are examined carefully it will be seen that it is very difficult to separate the small hind wing from the larger front wing. With a good hand lens, better with the microscope, there will be found a line of hooks fastening the hind wing to the front wing, fitting over a strong vein at the hind margin of the front wing.

The first abdominal segment is usually fused with the thorax, and that means that the small segment which forms the articulation between the thorax and the abdomen is usually the second abdominal segment. This is especially true in the wasps and the ants. 
The mouth parts of the honey-bee are fitted both for sucking nectar from flower cups and for eating pollen. (Fig. 62.) Many wasps eat pollen. Ants are noted for their strong jaws and yet they are very fond of sweet liquids. The so-called paper wasps make the paper for their nests by chewing bits of bark or wood to a pulp.

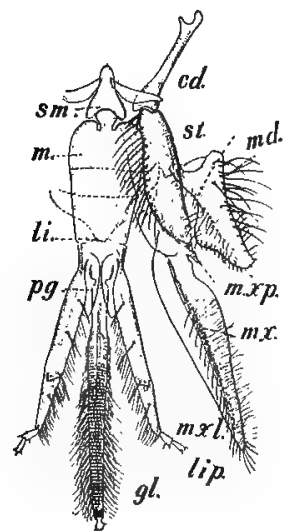

FIG. 6r.

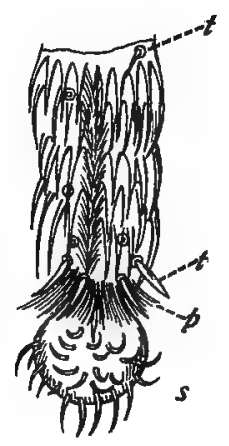

FIG. 62.

FIG. 6I.-Mouth parts of honey-bee, with right maxilla and mandible removed. $m d$, mandible; $m x$, maxilla; $m x p$, maxillary palpus; $m x l$, maxillary. lobe; st, stipes; $c d$, cardo of maxilla; $l i$, labium; $s m$, submentum of labium; $m$, mentum of labium; pg, paraglossa; $g l$, glossa; lip, labial palpus. (Kellogg.)

FIG. 62.-Tongue of honey-bee, Apis mellifera; $p$, protecting bristles; $s$, terminal spoon; $t$, taste setæ. (Folsom, after Williston.)

The gallfy larva lies in the midst of the gall, which yields it the most nourishing of plant juices. Hence, it is evident that, whatever the generic peculiarity of the mouth parts, all members of the order can either bite, or suck or lap; and most of them have both methods of feeding. In addition, the honey-bee has her mandibles so shaped as to make effective trowels for moulding the wax to make 
the delicate walls of the comb, or for manipulating the propolis to repair the comb in case of accident.

The ovipositor of the females throughout the order presents some curious modifications. In the case of the horntails and the big Thalessa, we have seen that the ovipositor is modified into a drill for depositing the eggs under the tree bark. Among the saw-flies, the ovipositor serves as a saw to cut into young stems or leaves in order to deposit the eggs therein. Among most of the ichneumons, the gallflies, and practically all the parasitic hymenopters, the ovipositor is used as an awl to prick a hole in a leaf, a stem, or the epidermis of some caterpillar in which to deposit the eggs. The queens-colony mothers - and the workers-infertile females - of the wasps and the bees, and the stinging ants, all have the ovipositor formed to serve as a sting. This sting is the most effective means of defense possessed by insects.

This last fact presents a curious anomaly among the members of the animal kingdom, at least among the higher orders. It is usually the male that is the larger and endowed in such a way that he is the defender of the home and the offspring. Among the lower groups, after the appearance of the male as a factor in the reproduction of the species, it is the female that is the larger and also the defender of the home and the offspring where there is a definite place of abode. In the order of the Hymenoptera, which is considered well up toward the highest of the insects, if not at the head, we still see the male in the place of subordination; especially is this true among the community hymenopters, the highest of the hymenopterous families.

The hymenopters all have complete metamorphosis, and the larvæ are peculiarly dependent upon the parents 
for food and safety. With the solitary wasps and the bees, the food is stored in the locule in which the larva hatches. The same is true of the gallfly, where the sap of the wounded plant furnishes food for the gallfly maggot. The parasitic ichneumons place their eggs in situations of abundant food supply for the hatching grubs. The young hymenopter is unable to provide food for itself, but grows up on the food which the careful mother provides. This dependence reaches its climax in the community wasps, bees, and ants, especially in the ants. Here certain workers bring food to the larvæ continually until pupation takes place; and even the pupæ are carefully carried about to places of warmth or safety.

\section{Bees.}

There are several sorts of flies that closely resemble bees in their hairy bodies, shape, and general appearance, but will be found to have only one pair of wings. The clear-winged Hemaris among the moths looks' very much like a bumblebee with its black and yellow hairy body, but its wings always have some scales on them. The bees, while not very difficult to recognize, may always be distinguished by the absence of scales on their wings, by the presence of feathery or branched hairs on head and thorax, and the enlargement of the mandibles for troweling wax or for tunneling in wood or ground.

The antennæ of the bees are bent near the head, and their terminal segments are provided with numerous sense-pits and papillæ; these pits are supposed to be organs of taste and feeling, and they also probably serve the purpose of olfactory organs. The sense of smell reaches its highest development in the community 
hymenopters; and the known ways in which the members of the group use this sense is truly wonderful, to say nothing of the marvelous actions in which we can only conjecture that smell plays a part. You have known bees to find honey which it was impossible for them to

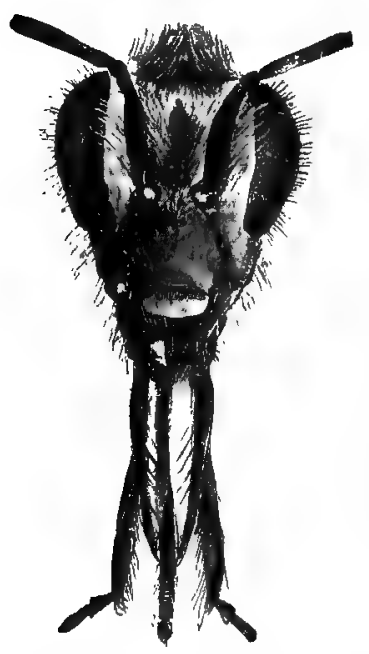

FIG. 63.-Head and mouth parts of honeybee, much enlarged. Note the short, trowellike mandibles for moulding wax, and the proboscis for sucking flower nectar. (Kellogg.) have seen, and which they must have found by their sense of smell. Ants will crawl long distances toward a bait of honey. Ants know each other and the home nest and the rival communities by the sense of smell.

A honeybee community consists usually of about ten thousand individuals in the winter, to about fifty thousand in the summer, one of which is a fertile female, the queen. Fifty to eighty, or several hundred of the total number are drones, and the remainder are workers, that is, females for the most part incapable of laying eggs, though there have been known cases of egglaying by a worker bee. These workers attend to the work of the community strictly. There is no division of interests here; the interest of one is the interest of the community. An exception to this oneness of aim must be made in the case of the drones. These individuals neither labor at any given part of the whole task, nor do they even provide food for themselves. Not even a job as policeman of the community attracts them, and this is a 
position much sought after in human metropolitan communities. They are rightly named drones, staying within the hive unless pushed out, living off the labors of the foraging workers, profiting throughout their short, lazy lives at the expense of the industrious. And this seemingly inexcusable waste in an organization so economically ordered, is solely for the purpose of providing for the propagation of the bee kind. It finds its counterpart in the cornstalk among the plants, which makes thirty thousand grains of pollen in its tassel in order that perhaps three hundred grains may be useful in producing the full, ripe ear of corn. Here is a valuable lesson for us human workers at our tasks. Nature does not grudge the effort; above everything she assures herself of the accomplishment of her purpose-rich effort, sure reward!

These drones wait for the advent of the queen, in order to take part in the mating flight. All the drones may start out with the queen; but gradually the weakerwinged individuals fall back, leaving the strongest drone to follow the queen high into the air. As the result of this union come the hundreds of eggs which the queen will lay during the time that she remains the mother of the colony. But the victor drone perishes at the moment of victory, having actually given his own life for the lives of the colony to be.

As to the mode of formation of a colony: in some of the comb cells reserved for that purpose the queen from some older community lays fertilized eggs, one in each cell, and at the same time the workers are busy storing other cells with honey and pollen. In three days these eggs hatch into tiny soft-bodied grubs. These are fed by the nurse-workers with honey and with bee jelly. Honey is 
not flower nectar, but is made from it and holds much less of water than does the nectar when it is sipped from the flower by the bee. Some bee keepers insist that the nurse-workers feed these first larvæ on honey and bee bread alone. Bee bread is made from pollen. If the bee jelly is fed to these first larvæ its use is discontinued after two days, and then the larvæ are fed on honey and bee bread for three days longer. After these five days of feeding, the nurse-workers roll up a mass of honey and

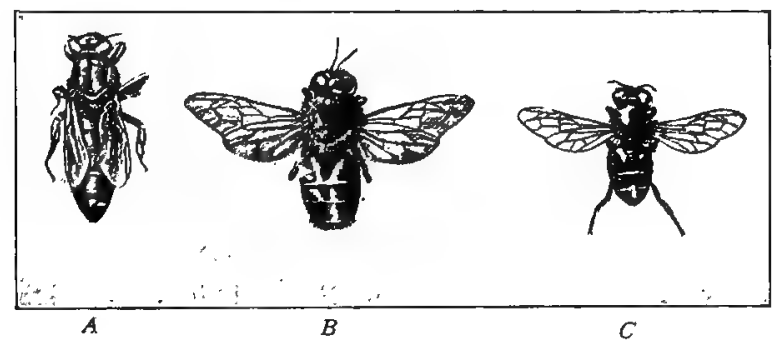

Fic. 64.-The honeybee, Apis mellifera. A, queen; B, drone; C, worker. (Natural size. Folsom.)

pollen, and put it beside the larva, which by this time has grown to a considerable size; they then cap the cell and leave it. The larva eats a little longer, then pupates in in the cell, remaining a pupa for thirteen days, after which a full-grown bee appears. (Fig. 64.) This young bee stays in the hive for some days, sharing in the in-door work with the bees somewhat older, serving as a nurse-worker itself. It would seem from some observations that have been made, that only the young bees are capable of acting as nurse-workers, and that they become foraging or general workers at a more advanced stage of their existence. If this is true, then there are no hard and fast lines of caste among the workers; all serve an apprenticeship in the 
HYMENOPTERA.

nursery, and in the kind of work performed later, age plays a part. This somewhat unsettles the belief in the specialization which has been supposed to exist in a bee community. After numerous broods of workers have been added to the community the workers build some larger cells in which the queen lays some unfertilized eggs, and from these hatch the drones. These larvæ are fed by the nurse-workers, and with the same food, but in this case the larval period lasts six days and the pupal period fifteen days: When the community is so large as to crowd the hive, at least that is the way we have of saying what the bee has a finer instinct for knowing, the combworkers tear down some of the cells, usually, and build up a few giant

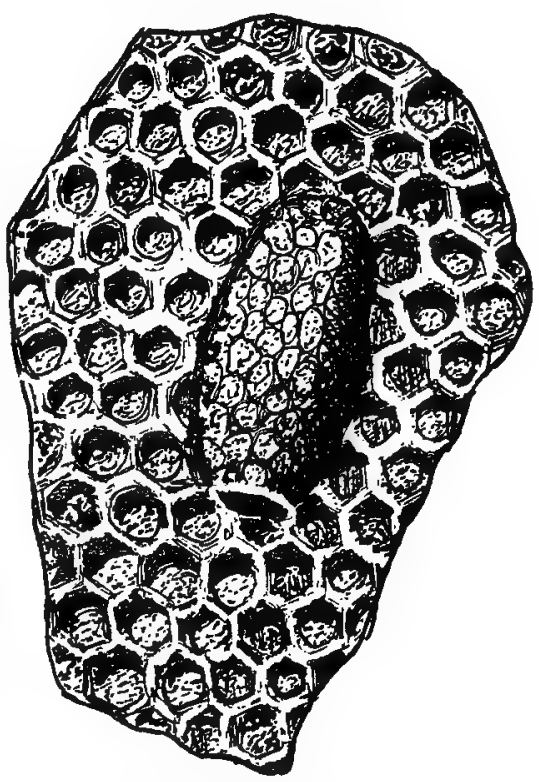

Fig. 65.-Portion of brood comb of honeybee showing one queen cell. cells or queen cells. They may build them on the outside of the comb cells, and they are usually at right angles with the other cells. (Fig. 65.)

From what source comes this impulse for building queen cells is not known. At any rate, their being built is not known early in the history of the colony when the hive is scantily filled with bees. Bees seem unable to count, and it would be equally strange to accredit them 
with reasoning power by which they might know when to build queen cells. It would hardly seem that the queen would give the signal herself; for the appearance of a new queen brings her two possibilities which she must face-the end of her reign over a united community, or death-generally the latter. At any rate, the stimulus is given and the eggs are laid. Occasionally the cell is built up around an egg already laid. These are the royal larvæ which hatch from these eggs, and each is fed by several nurse-workers in constant attendance, feeding bee jelly for the five larval days. After these five days of constant feeding, the nurses place a mass of bee jelly beside the old larva and cap the cell, and in seven days more, there appears the full-grown queen. This bee jelly, on which the royal larva is fed, is a highly metamorphosed honey product elaborated in the body of the worker and fed to the larva by regurgitation. So far as known, it is the feeding which makes the difference in the individuals resulting from the two fertilized eggs, the one in the worker cell and the one in the queen cell. The royal larva is fed longer, constantly, and with richer food than is the worker larva.

The appearance of the queen is heralded by a curious piping noise which the old queen answers, and the battle is on. If the old queen attempts to attack the young queen the workers usually protect the young queen, at least a portion of them may so decide to do; this may result in the migrating of a portion of the hive with the old queen leaving the new queen in possession of the remaining bees in the hive. If more queens than one issue at one time, there may follow a series of battles in which it is decided which one among them is to stay with the hive; or there will be a series of swarmings which 
will divide the community into swarms, one for each queen surviving. Sometimes the workers interfere in a possible battle of the queens and kill either the old or the new queen by gathering in a tight ball about her and suffocating her. The sting of the worker is rarely, if ever, used against the queen; and the queen does not use her sting save in one of these battles royal against one of her rivals. The matter having been settled, the diminished community in the hive sets about the work of building up another community, while the exiled swarms do the same elsewhere. It usually comes about in the case of the exiled swarms that some one sees the swarm hanging to a tree branch and uses his diligence to secure it and put it into another hive; but occasionally one of these swarms escapes and makes itself a nest in some tree and the bees become wild again, as they were originally.

With the bumblebees, at the end of the summer, the nest is abandoned; none stays in it. The old queen mother, the drones, and the workers die, leaving the young queen to winter through in some sheltered situation. Such colonies are not permanent, nor do they tend strongly toward the persistence or the spread of the species. Among the honeybees, the many generations of workers hatched during the summer season, the providing of the overstocked hive with several queens, and the swarmings incident to the growth of such a brood colony tend directly toward the persistence of the bee kind through the spread of enormous numbers of them. Our hive honeybees are all of European stock; the native bees are the familiar bumblebees; while our wild bees are swarms of the domesticated sorts which have escaped from the artificial hive to the wild life again, where they build their comb of wild honey in some hollow tree. The swarming 
of bees, bringing about the formation of new colonies, plays an important part in the preservation of the bee kind. It is quite as necessary that the communities be multiplied as that the numbers of the community be increased.

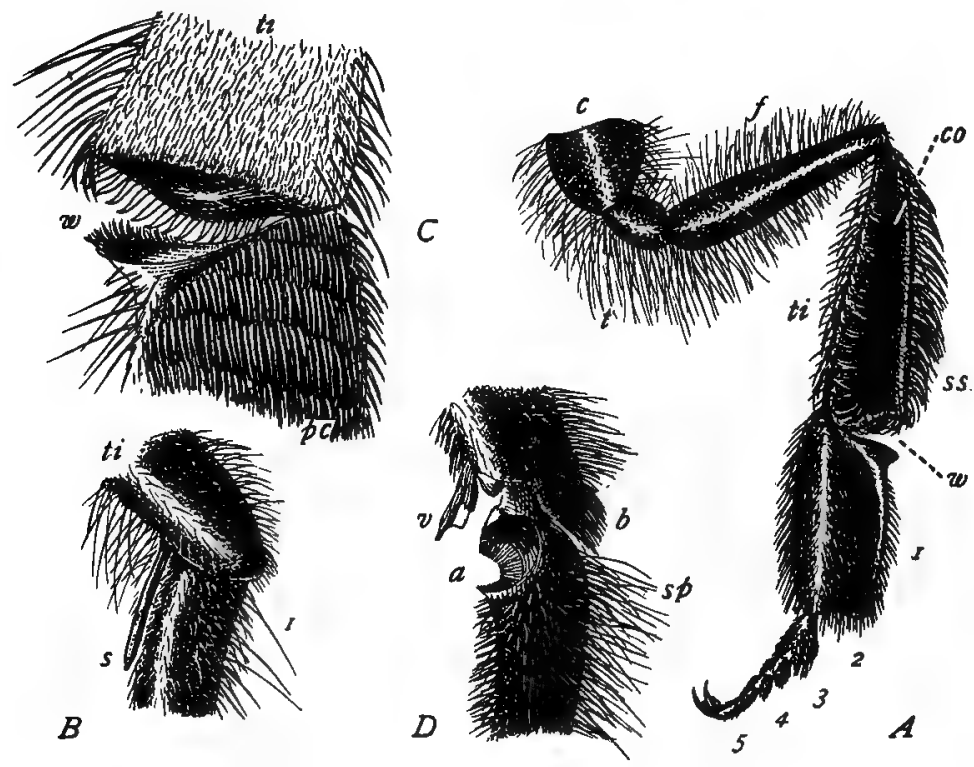

FIG. 66.-Adaptive modifications of the legs of the worker honeybee. $A$, outer aspect of left hind leg; $B$, portion of left middle leg; $C$, inner aspect of tibiotarsal region of left hind leg; $D$, tibio-tarsal region of left foreleg; $a$, antenna comb; $b$, brush; $c$, coxa; $c o$, corbiculum; $f$, femur; $p c$, pollen combs; $s$, spur; $s p$, spines; $s s$, spines; $t$, trochanter; $t i$, tibia; $v$, velum; $w$, wax pincers; $\mathrm{I}-5$, tarsal segments; I, metatarsus, or planta. (Folsom.)

Some of the industries of the hive are wax-making, comb-building, honey-making, repairing, garbage-collecting, cleaning, warming, and ventilating the hive, sentinelkeeping, water-carrying, nursing, and fighting. 
Of the honeybees, the legs at the base, the thorax, and the abdomen are covered with flexible branching hairs which are for the purpose of gathering up the sticky pollen from the flowers visited. When the body surface is pretty well loaded, these pollen grains are combed out into the pollen bags on the outer side of each hind leg. If you watch one of the foraging bees, you may see her cross the hind legs and scrape the pollen grains into the

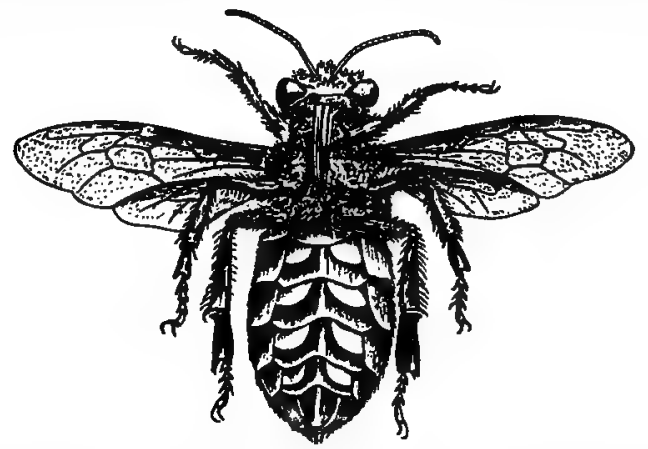

FIG. 67.-Ventral aspect of worker honeybee, showing the four pairs of wax scales. (Folsom, after Cheshire.)

pollen bag on the opposite side of the body by means of the pollen combs on the inner surface of the hind legs. Arrived at the nest, the hind legs are thrust into the cell and the pollen load is pried out by the pollen spur. This spur is also used in cleaning the wings, and is possessed by the queen and the drones also; but the other pollen adaptations are possessed by the workers only.

In the making of wax the workers eat a large amount of honey, then hang themselves together from the ceiling of the hive in a curtain, each bee clinging to the bee above it and the bees uppermost to the hive roof. These wax-workers seem to hang quietly, but they are really working very hard. They must in some manner bring 
about the production of wax by some internal process, alimentary in its nature. At the end of about a day, as the result of this process, there appear shining scales of wax from between the segments of the abdomen. The comb-workers may run about this living curtain, scraping off the wax scales as they appear, to be put where they are needed in the building of the comb, or the wax-maker may scrape off the scales herself. It is not certainly known just how this is done.

The bees whose business it is to furnish honey for the hatching larvæ drink nectar. By increase of body temperature, probably, some of the water present in the nectar is driven off, and, at the same time, the volatile odors or oils peculiar to the different flowers from which the nectar was gathered, are driven off in large measure also. This honey is then regurgitated from the honey stomach of the honey-maker into certain comb cells where it is drawn upon by the nurse-workers; or if a honey-maker, on entering the hive, meets a nurse-worker it may there give up its nectar store to the hungry nurse. At times the foraging bees bring in water, which they probably get from flowers while the dew is on them, though bees also drink from bodies of water. This water constitutes part of the diet of the young worker bee.

Another substance is also brought into the hive, the resinous products of some plants; it is called propolis, and is used in the repairing of cells or the stopping of cracks in the comb, and especially in making the comb joints perfect and the hive warm for the winter.

\section{Ants.}

The ants have no solitary species, all of the more than two thousand species living in communities. The head of 
the community seems not to be in any sense a director or an organizer, but rather a mother of the community. An ant community always includes winged males which die soon after their issuing from the nest to take part in the mating flight; also winged females or mothers which pull off their wings immediately after this flight, and wingless workers or infertile females. These workers may be of two sizes, though this is not always true. There are usually the soldier workers with unusually large heads and jaws.

Taking the common carpenter ant as a type: the ant mother begins the colony alone, feeding the first larvæ herself with food which she brings into the nest before she lays her eggs. This is according to Comstock's observations. After the first brood comes to maturity the members act as foragers and nurses for the succeeding broods, and the ant mother has nothing to do from that time forward except to lay eggs for the community increase. The nests are built usually beneath the ground surface, some being built under stones; or you may have seen ants excavating between the stones of the sidewalk, popping into sight with a crumb of soil, dropping it to roll down the side of the tiny mound, and scurrying back for more, always more, as the underground galleries multiply. The eggs are laid by the ant mother in masses instead of singly as in the bee kind; and the larvæ are white, soft, footless grubs, very tiny at first, but growing to considerable size. They are fed regurgitated food or fresh insects well chewed, or weeds chewed up, or some other vegetable food previously brought into the nest and stored in the granaries. Of some species the larvæ must be fed for a month. The pupæ look light-colored and soft, but are not fed, though they are taken as much 
care of as are infants among the human kind. The nurses must move eggs, larvæ, and pupæ about in the nest from room to room, up or down, as the need may be for keeping the developing insects at the temperature best for their development.

The various ant industries may include honeygathering from plant lice or from fresh galls on oak trees. This honey supplied by the tree is a sweetish liquid exuded from the plant where some insect has stung it in the act of laying its egg; and the wounded plant is in some way influenced to secrete about the greedy larva this sweetish fluid which is watched for by the ant, licked up and brought into the nest to feed the young ants during their immature stages. Among the Camponotidæ an additional class of workers must act as honey jugs, in which the honey brought in by the foraging ants is stored, to be served out at some future time on the requisition of some nurse-worker. Others have laid upon them the task of foraging for the animal or yegetable food also used in feeding the larvæ, and eaten as well by the indoor workers, the males, and the ant mothers. Have you not often seen two or three ants tugging away at some beetle or worm a good deal larger than all of them put together, pushing and pulling all the time, seeming to have just one idea in their stubborn heads, that that worm must be got home at any cost? The vegetable food gathered consists largely of plant seeds which are stored in the granaries, extra large chambers or galleries. The cleaning of the nest often results in some of these seeds being brought out, and it not infrequently happens that some of them grow where they are dropped. This may account for the ant fields and the ant husbandry so often spoken of. 
The animal food usually is some freshly-killed insect, possibly killed by the foragers themselves. In one instance the writer found four of the red-brown pavement ants attempting to carry off one of the common ground beetles that had evidently been stepped upon by some passer-by. One of its legs stuck out sidewise in such a position that it kept catching on everything, and finally the four ant-draymen were brought up standing, with the troublesome leg caught under a grass leaf lying on the walk. Curiously enough, the four excited ants did not resent or even seem to notice when their human friend stooped down and poked the beetle around so as to free its body; but off the four started with their load, as triumphantly as if they had done the thing themselves.

An ant nest, such as may be found in dooryards or fields, may extend down two or three feet below the ground surface, and contains scores of galleries with narrower passages connecting, more intricate than the famous catacombs, and taxing the ingenuity of even an ant to find the way to the surface. There is but one opening to the nest. At first there is but one ant mother, and the nest is small; but as the broods multiply the nest may become enormously enlarged. In an old ant community there are usually many ant mothers. The males and the females of a young ant community, or of any branch community, come out of the pupæ cases winged; and their first feat is the accomplishment of the nuptial flight or the marriage of the ants. Flying ants are not especially agile, and are frequently eaten in large numbers by insectivorous birds; but such females as survive, pull off their own wings and scurry underground, usually returning to the nest from which they took their flight, though they may seek a new location. The males 
usually fall to the ground, where they may fall a prey to any watchful sparrow.

The ant colony is practically perpetual, owing to the facts that branch colonies are added indefinitely to the parent colony, and that the ant mothers are unusually long-lived. Sir John Lubbock, in his interesting book of observations on ants, bees, and wasps, records the fact that he kept two ant mothers six years, and some of the workers in his artificial ant nests lived more than seven years.

\section{Wasps.}

Comstock divides the wasps into the Sphecina and the Vespina. The Sphecina are those wasps that have the habit of burrowing into the ground or into wood to make provision for their young, though there are some peculiarities of nest-choosing even within the class of the Sphecina. All of them are solitary; that is, each female makes provision for her own young. The male does not live long beyond the time of mating, the third example among the hymenopters of the subordination of the male in the economy of the species.

The true digger wasps, those typical of the class, make burrows in the ground, provisioning them, and laying one egg in each burrow. The spider wasps, socalled because they provision their burrows with spiders, as a rule burrow into the ground after the manner of the family to which they belong; but others of them make a nest of mud which they attach to the under side of some stone, while others still live as guests in the nests of other digger wasps.

The thread-waisted wasps, known as mud-daubers, fasten their clay nests up in the corners of our verandas 
or close up under the eaves, or, failing an entrance to such a favored locality, they will glue them to the under side

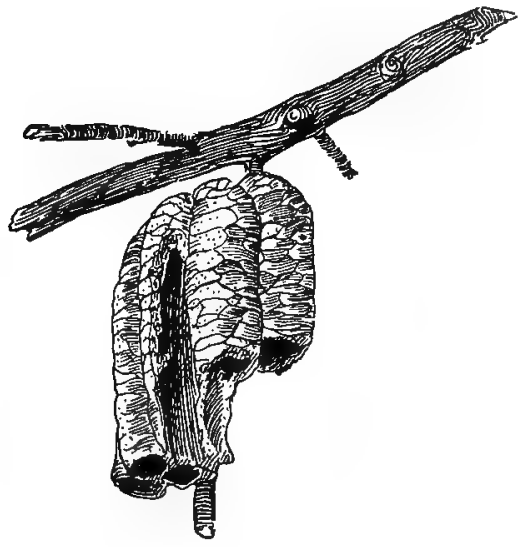

Fig. 68.-Nest of a mud-dauber. (Natural size. Kellogg.)

of stones. If you watch a mud-dauber at work you will notice the curious habit it has of jerking its wings frequently.

One family of the digger wasps deserves special

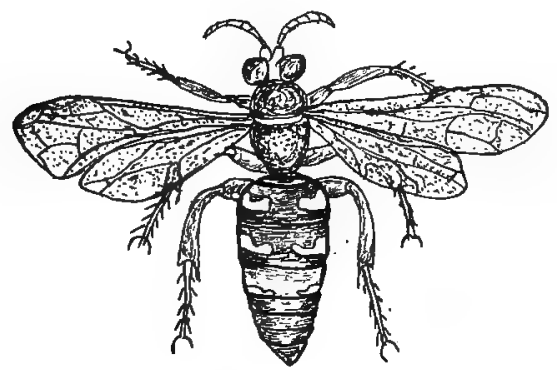

Fig. 69.-The cicada killer, Sphecius speciosus.

mention; it is the family of the Bembecidæ. These wasps are to be expected to make more noise than a wasp 
ordinarily does-their name is given because of this peculiarity. (Fig. 69.) In this family we find the cicada killer, a wasp over an inch long, rusty black in color (though sometimes brighter black than rusty); the abdomen has three yellow bands, interrupted in the middle line along the back. This big wasp burrows into the pith of plants for a nest, and provisions her burrow with

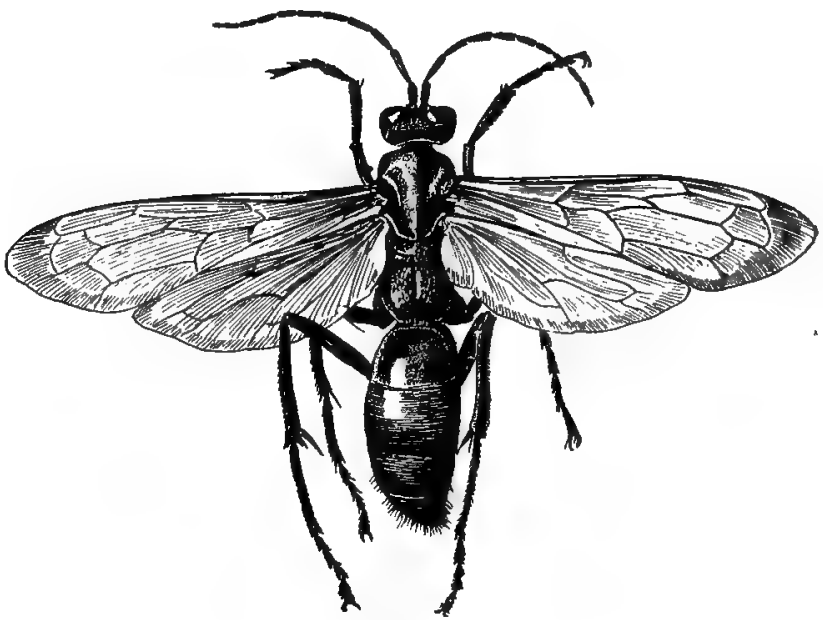

Fig. 70.-The tarantula killer. Pepsis formosa. (Natural size. Kellogg.)

a single cicada, upon which she lays her egg. Here also is the giant of the whole wasp tribe, the tarantula killer. This insect is mentioned by Kellogg as common in California and the Southwest, and it is also found in the Middle West. (Fig. 70.) It measures about two and one-half inches in length and has a spread of wings of about three and one-half inches. The body is shining blue-black, and the tawny wings are bordered with black.

These two powerful wasps have in the greatest per- 
fection the wonderful instinct of knowing just where to sting their victim to render it helpless. Of course a cicada is foolish enough to announce its whereabouts by its shrill singing, so that the cicada killer has little trouble in locating its prey; but the cicada is as powerful as its enemy; and a good deal more bulky. The tarantula must be "stalked" more cautiously because it makes no noise. For the cicada, one stab is enough; but for the tarantula, owing perhaps to the almost equal wariness of the two contestants, a battle is necessary to decide which one shall come off victor. In either case, it remains that the two big wasps, without being taught, know just where to insert their sting, and both usually are victorious.

Others of the digger wasps also burrow into the pith of plants and provision the burrows with freshly-killed insects. "The kind of insect selected is usually so constant that insect collectors come to know their wasp by the kind of insect found in the burrow.

As to the reproduction of the Sphecina, we may take a typical example. When the egg-laying time arrives, the female selects the place for her burrow, though in one species the insect provision is secured first and laid to one side while the mother wasp digs the burrow; but usually the burrow is first looked after. Then the prey is secured, and this the wasp usually paralyzes by stinging in one of the thoracic ganglia, each one of the bugs or spiders, or caterpillars used. With some of the species the prey is killed; but in either case it is placed in the burrow, the egg is laid upon it, and the burrow is closed. The mother wasp then goes away to make new burrows, stock them, and lay more eggs. Others of the class take a little different method, amounting to more care in looking after the young. With these wasps the 
mother goes back to feed the growing larva, taking with her freshly-killed insects each time till the larva is ready to pupate, then she goes away permanently.

Some of the solitary wasps burrow into the ground until they find a fat grub, and in this they lay their egg, whose larva will find fresh meat ready without any further provision on the part of the mother. The egg hatches in from one to three days, depending upon the species. The old larva spins a cocoon about itself and enters upon the pupal stage. In two or three weeks, if the egg is laid in the early part of the season, or the following spring if the egg is a late egg, there comes out a fullgrown wasp.

Some solitary wasps conceal their burrows carefully with twigs, pebbles, or straws, returning to it with ease. From this it seems that we must accredit the wasp with a fairly good memory and eyesight, even though it be memory that develops each time out of the successive recurrence of the same stimuli, which is conceded to be the lowest form of what we call memory. The fact that the wasp mother flies each time to her burrow without apparent hesitation. would argue that she knows the way much as you and I would know our way. Another fact that should be mentioned is the preference of wasps for sunshine. In this connection it will be profitable to note that the sense of sight, while it reaches a high degree of development among the Hymenoptera, nevertheless has degrees of excellence within the order. Bees see much better than do wasps, and it is probable that ants make the sense of smell do much for them that sight would otherwise do. Wasps will work the center of a blossoming field, rather avoiding the shaded edges.

The social wasps can be distinguished from the true 
solitary wasp by the fact that they fold their wings along the back when they alight, plait them, that is, while the wings of the solitary wasp are left flat when at rest. It probably would be more nearly right to say that a wasp which plaits its wings is one of the Vespina, since, because of other features, it is necessary to include among the wasps that fold their wings along their backs some wasps that have the solitary habit clinging to them. The life of the social wasps does not present so close a community organization as does that of the bees and the ants. The wasp colony, consisting of all the individuals hatching from the eggs of one queen, persists during the spring, summer, and autumn, but generally the only members of the colony to hold over through the winter are the fertilized females. The males usually die early. The females hibernate in some sheltered place, ready to crawl out with the coming of spring and begin the formation of a new colony. Not only is this true, but the workers are not, apparently, so well apportioned off into classes; one worker seems to do several kinds of work. The workers are smaller than the drones, and the wasp mother is distinguished from the workers by her greater size. (Fig. 7 7 .)

In the spring the mother wasps that have wintered over make, one each, a nest containing a small number of brood cells and lay one egg in each cell. Usually the wasp provisions each cell with insects that she has killed and partly chewed. The larvæ of this first brood are fed daily by the wasp mother, the food being of the same kind each time; the larva soon pupate in the cells. This generation is a generation of workers; the brood which consists of males and queens does not appear till later in the season. The young workers begin at once to enlarge 
the nest, making new brood cells and adding to the supports of the increasing nest. In each of these cells the mother wasp lays an egg. Several broods of workers are thus reared with the help of the young wasps which act as nurses to the hatching larvæ; and then comes a

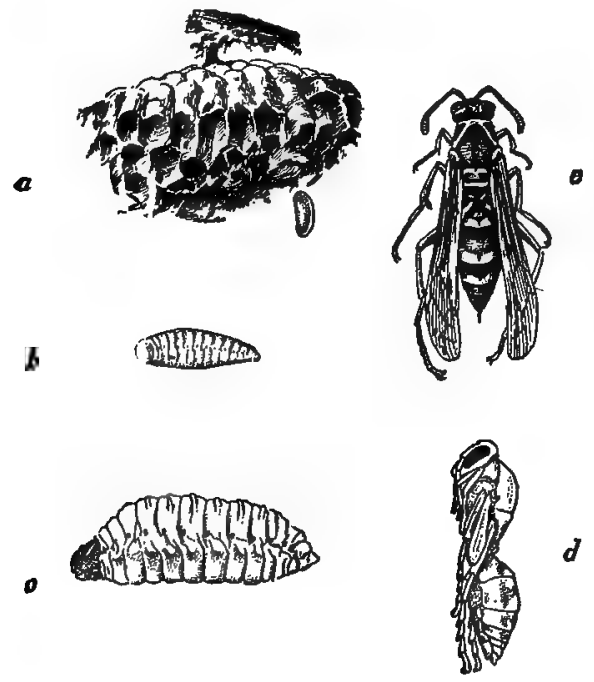

Fig. 71.-Nest of a paper-wasp, Polisies, $a ; b$, young larva; $c$, older larva; $d$, pupa; $e$, adult. (All one and one-half times natural size, except nest, which is much reduced. Kellogg.)

brood of workers, males, and queens. The males live long enough to fertilize the females and then die, leaving the females to continue the species.

The nests of the Vespina are placed in various situations, underground, under the eaves, on a tree branch, or in some sheltered house corner. The potter wasps-the Eumenidæ-make nests of clay or mud and fasten them to the branch of a tree. This is the family representing the connecting link between the Sphecina and the Vespina, 
resembling the Sphecina closely in habits, but differing from them greatly in structure; and it is on this structural basis that they are classed with the Vespina, although they are solitary wasps.

Others of the Eumenidæ build a series of cells in the pith of some plant, burrow into the ground, or use burrows dug by some other wasp or by some different kind of insect. Most of them store their burrows with caterpillars; one species uses the saw-fly entirely as food for its young. Outside the Eumenidæ, the majority of the Vespina build their nests of paper. This paper they make out of old bark or wood chewed to a pulp and mixed with the saliva of the wasp-workers. Occasionally shreds of leaves cast up by the water's edge are utilized, and this material seems to make a paper even stronger than the usual material. 


\section{CHAPTER XII. \\ FIELD WORK ON THE DIPTERA.}

This is such an immense order that there will be attempted the study of only a few of the familiar dipters.

These are the days of crusades against mosquitoes, nevertheless there may still be found breeding-places where may be seen the familiar wrigglers or mosquito larvæ. If you find such a breeding-place, bring in a cupful of the water with the wrigglers in it. Divide it into two. parts and carefully pour on to the water surface in one of the two tumblers enough kerosene to cover the water surface with a thin film of oil. When you think you have enough oil, watch the wrigglers to see what is happening and to convince yourself of the effectiveness of this treatment. What is the cause of the death of the larvæ? Do the dead larvæ sink or float? What is the reason for their position? Could their death be called drowning?

With the reading glass examine the immature mosquitoes in the other glass. Are all the immature mosquitoes alike? Can you find any pupæ? What are the pupæ doing? Can you discover what the larvæ are eating? Do the larvæ, when they come to the surface to breathe, rest parallel with the surface of the water or at a decided angle? If you find parallel mosquitoes are they malarial mosquitoes or not? If they hang at an angle, what diseases may it be possible that they are carrying? Both these forms of mosquitoes may at some future time be 
prepared to do just these things in your community, and you may be one of the victims; hence the only safe thing is to kill every one of them after finishing up the investigation work. It will be best to put a piece of mosquito bar over the cup to catch any adults that may emerge while you are not watching. Can you find any such adults?

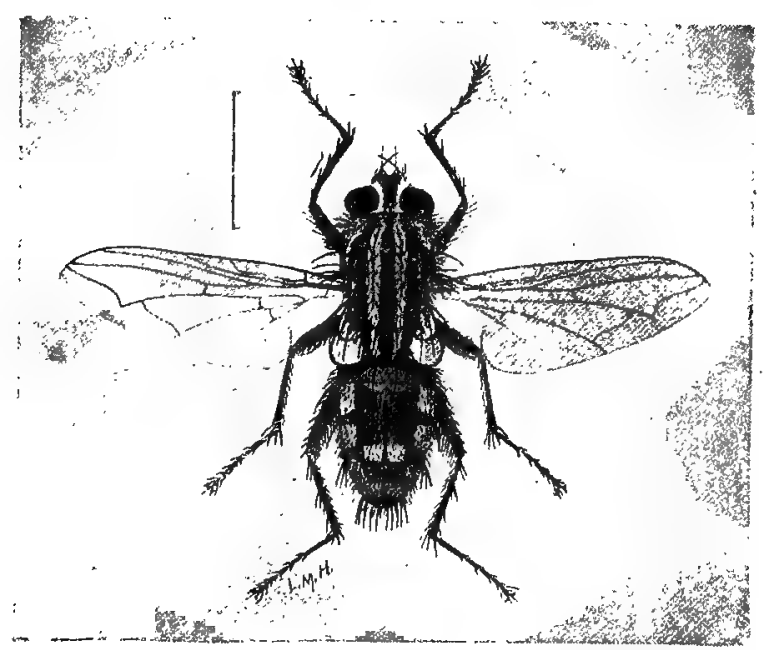

FIG. 72.-A blow fly or flesh fly. (Kellogg, after Lugger; natural size indicated by line.)

After you have had the family under observation for several days, use the reading glass often to keep track of what is going on. If in your neighborhood there are some suspected breeding-places for mosquitoes, visit them and take along your bottle of oil.

Learn for yourself that house flies and stable flies breed in filth, by finding their larvæ or maggots in manure or refuse piles. If you will keep your eyes open, you may 
be able to discover that carrion flies-flesh flies - breed in decaying carcasses and also in some other places coming closer to the life and health of the human family. (Fig. 72.) Notice what happens in hot weather when meat from the dining table is not disposed of in a cleanly way after the meal.

It will be easy to catch some half dozen flies in a room, school-room or other room. Try to discover with the hand lens whether the six flies are all of the same sort, that is if they look alike. Bear in mind that, when a fly emerges from its pupal case, it comes out adult in size as well as in powers. Do you find any stable flies among the half dozen captured?

An expedition should be made to the open fields; and for this the dip net will be better than the butterfly net. You are going after flower flies, and you will find them hidden in flower clusters. Bring your dip net over a flower cluster, give the flower stem two or three decided taps, and you may be rewarded by the upward flying of several glistening green or otherwise brilliantlycolored flies. If you have with the other hand kept the net open, the flies will fly upward into the top, and you can fold the net over upon itself once and keep them prisoners long enough to have a good look at them with your hand lens. These are the syrphids or flower flies; though it is quite possible that you will also find in your net some of your beetle friends which also frequent flowers. The syrphids are the flies that have been occasionally known to eat solid food, a few pollen grains; but all other dipters, so far as known at present, partake only of liquid food, excepting the rasping off of sugar crumbs, but these are soon dissolved in the mouth fluids and are also swallowed as is the usual liquid food. 
These syrphids are beneficial both as larvæ and as adults, many of them being predaceous in the larval stage; hence they must be set free after you have looked at them long enough to be able to recognize them, if you were to see them again. These flower flies have some representatives that like the shady woods-a thing rather unusual for flies, as flies notably like sunshine and warmth; so an expedition with the insect net and the hand lens may find some of the other syrphids, the object being to discover what these beneficial flies look like and where they are to be found, all with the view to letting them alone after you have the knowledge sought.

The harmful flies are, often given names which tell what they do, as well as often giving a clue as to where to find them; as house flies, stable flies, bot flies, horse flies. On the window pane of some open room in the course of an hour, several sorts may be captured; and after determining with the aid of the instructor whether there are any valuable flies among them, they may be put into the killing bottle, and should be set up as soon as they are dead. The pins should be slender and are to be thrust through the thorax, the fly being set well up toward the head of the pin. When a harmful fly is captured in the field, it is advisable to have the killing bottle along, in order that the delicate insect may not be put into the collecting box along with other larger and more powerful insects; after the fly is overcome by the fumes of the killing agent, it should be pinned immediately. If it is allowed to shake around in the collecting box with all the other finds, it will be unrecognizable when it is most wanted. Few life histories of dipters are known, and knowledge of this sort is needed; here is a field for investigation. When one goes for the study of flies in this way, 
he should take with him forceps for picking the larvæ out of their larval quarters, and a small sieve for sifting them free from the refuse in which they may be found. They can be collected in a small bottle of alcohol, both larvæ and pupæ. 


\section{DIPTERA.}

\section{CHARACTERISTICS.}

I. Two membranous wings (when wings are present), usually transparent, and borne by the mesothorax.

2. Hind wings either redtuced to mere knobs, halteres, or halteres accompanied by minute wing-like organs called alulets.

3. Two compound eyes, either contiguous or separated by the frontal lunule.

4. Antennæ inserted near the top of the head line or midway down the face.

6. A curious, fleshy proboscis with tongue-like flaps, or a complex modification of the mandibles and the maxillæ, making needle-like, piercing stylets. 



\section{DIPTERA.}

This is the order of the true flies, and the members of the order are characterized by the fact that they have but one pair of wings, though there are some exceptions to this; there are some flies that do not have any wings, and, of course, such flies do not fly-they are parasites and live on some other animal as a host. After the term "bug," there is no more misused term than the name "fly." Anything that looks at all like a house fly is without hesitation called a fly; and nine times out of ten your friend will-understand perfectly when such a "fly" is indicated, and will see the fly which may not be a fly at all.

The order includes some insects that pierce the epidermis of other animals, not biting as do the beetles, but piercing, much as the bugs do; while in the other and much larger class of flies, the members of the different families must content themselves with lapping up liquid food, or rasping off small particles from some solid substance, these to be dissolved in the mouth fluids later and swallowed in the usual way.

Among other orders, there are numerous instances of the borrowed use of the term "fly"--May fly, dragon fly, gallfly, saw-fly, and butterfly-hence we see that there is not much in a name anyway. When we speak correctly of flies, we mean the dipterous flies with their two wings, then we use the term correctly and with accurate knowledge.

The hind wings of the flies are replaced by two queer 
little humps or knobs, called halteres, rudiments of the wings which, in the fly ancestor under far different circumstances, probably were present but are not now needed. and are only suggested by these tiny vestiges which probably play the part of balancers in flight. The tendency toward non-differentiated forms as we go downward in the scale explains why the wings in the
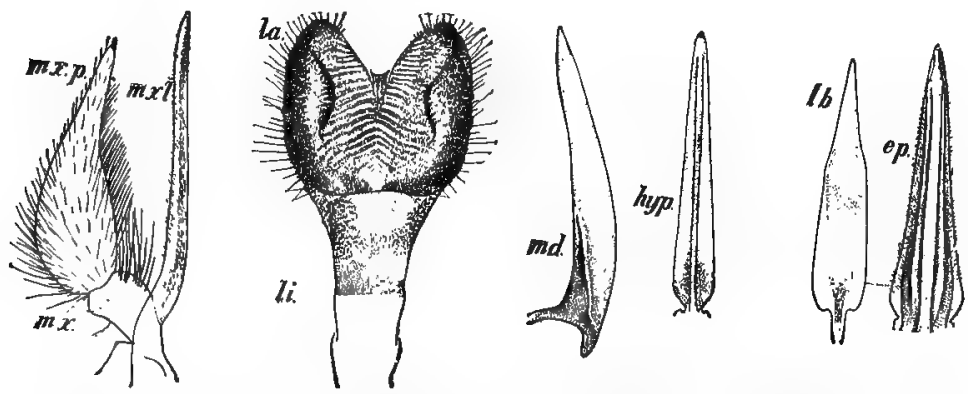

FIG. 73.-Mouth parts of a horse fly. $m d$, mandible; $m x$, maxilla; $m x l$, maxillary lobe; $m x p$, maxillary palpus; $h y p$, hypopharynx; $l b$, labrum; $e p$, epipharynx; li, labium; la, labellum. (Kellogg.)

lower insects are increasingly equal in size and similar in venation, while in the higher insects there is the apparent tendency to let one pair of wings get the ascendancy over the other pair. So here, in the Diptera, we have the hind pair of wings giving way altogether to the front pair, and we have a two-winged animal which gives evidence in other ways of being high in the animal scale.

The order includes house flies, carrion flies, flower flies, horse flies, bluebottles, bee flies, pomace flies, hessian flies, bot flies, robber flies, midges, gnats, dance flies, punkies, and the mosquito tribe. (Fig. 74.)

The mouth parts are not fitted for biting, but the mandibles, when present, together with the maxillæ, are 
elongated into slender, sharp-pointed stylets; but the majority of flies, as has been said, have the mouth parts adapted for lapping up liquid food much as a kitten laps up milk. This lapping mechanism is a modification of the under lip, a curious jointed organ which you may see a house fly use if you will put a lump of sugar down on some

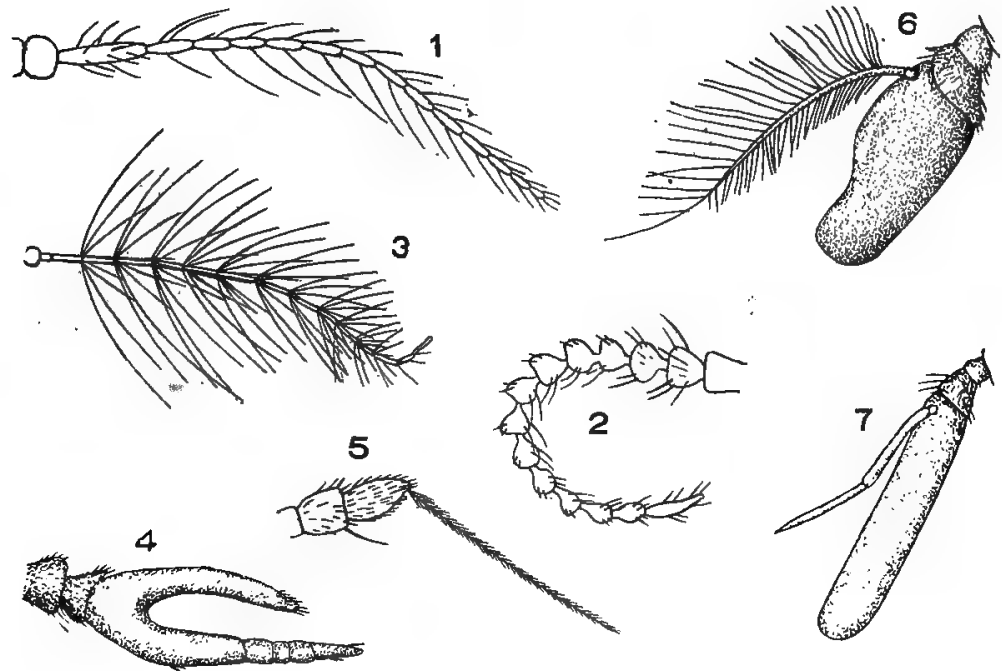

F1G. 74.-Various forms of antennæ of flies. (Williston.)

convenient surface and put your reading glass in position to use it at a second's notice. The members of the order having such mouth parts feed on the nectar of flowers, on the juices of decaying animal or vegetable matter, on some sweetish exposed liquid, or occasionally on some solid, as a lump of sugar. In the last case the solid must be rasped off, if one may so describe the act of licking the solid sugar, and then conveyed to the mouth where it is swallowed after solution. 
The compound eyes of all the non-parasitic dipters are many-faceted and large and placed well forward; and their convexity is such as to cause them to project considerably from the head, giving the flies keen and comparatively accurate sight. It is very difficult to catch a fly napping. In addition, some of the flies have eyes with facets of two sizes; these are flies spending the larval and pupal stages in the water, and are called midges.
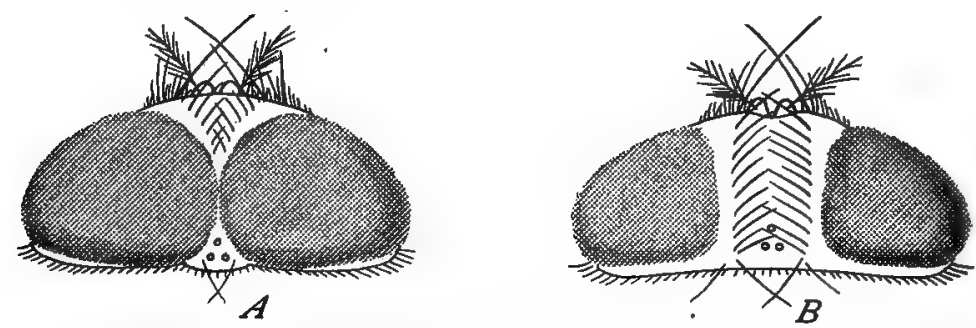

Fig. 75.-Ocelli and compound eyes of a fly, Phormia regina. $A$, male; $B$, female. (Folsom.)

The dipters reproduce by complete metamorphosis. The typical larva hatched from the egg is a white grub, or maggot, as it is popularly called. The eggs are laid in some mass of decaying matter, some filth, either animal of vegetable; hence the maggot has no need for the effective biting, piercing, or sucking mouth-parts with which other larvæ are provided. It is simply a helpless, footless, sometimes headless animal, obtaining its food osmotically through the skin. The larval moultings are usually rapid, and the pupal stage is soon reached. In this stage, in some species of dipters, the pupa looks not unlike a brown seed; it might well be mistaken for one if it were the pupa of a house fly. When the pupa case is discarded, there 
emerges a full-grown fly, complete as to its size and powers. Such flies are oviparous as to their manner of bringing forth their young. (Fig. 76.) This is the metamorphosis of the majority of the order; but there are flies that bring forth their young in a much more advanced stage; these are called pupiparous flies, as the young in

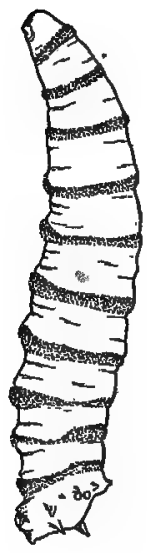

A
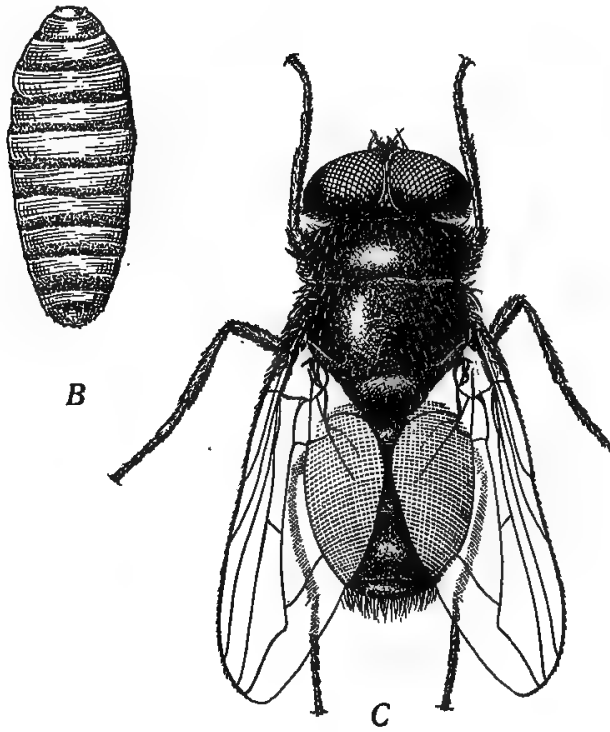

FIG. 76.-Metamorphosis of an oviparous fly, Phormia regina. A, larva; $B$, puparium; $C$, imago. $\times 5$. (Folsom.)

its first stage of life looks like a pupa. And there are still others whose young, when brought forth, are alive and in a stage like the usual larval stage. These flies are called viviparous, or larviparous.

According to Kellogg, the order may be divided into two grand divisions, ( $\mathrm{I}$ ) those living as parasites on mammals or birds or honey-bees, with the body flattened, 
and often wingless; the young of these flies are born alive; (2) those not living as parasites, body of the usual fly form, and the young usually produced as eggs.

The first division includes the bird ticks, the horse ticks and the sheep ticks, flat-bodied insects with skin more or less leathery, and with a single pair of wings; these ticks, of course, have six legs. The animals more rightly named ticks do not belong to the Insecta, but to another entirely different division of the Arthropoda, along with the mites.

The second division comprises the true dipters; that is, the typical insects of the order, and this division has much more numerous representatives than the first division. Among the harmful dipters, we have

Mosquitoes

Horse flies

Gallgnats

Bot flies

Beet flies

Screw-worm flies

Fruit flies
House flies

Stable flies

Horn flies

Cabbage-maggot flies

Hessian flies

Cheese skippers

Onion flies

And among the beneficial dipters may be mentioned:

Tachina flies

Long-legged flies

Midas flies

Dance flies
Syrphid flies

Bee flies

Wasp flies

Soldier flies

Of the harmful flies mentioned, those which are a menace to the health of human beings are the mosquitoes, the house flies, the stable flies, and the screw-worm flies. (Fig. 77.) The so-called house fly that gives you a sharp twinge as it pierces your skin with its stylets is not a 
house fly, but probably a stable fly, which looks a good deal like a house fly and frequently comes into the house and bites you, possibly because you taste better than its usual food. The stable fly has stylets for piercing epidermis, while the house fly can only lap its food. (Fig. 78.) The harmfulness of the house fly comes from another habit; it gets its supply of food from exposed decaying substances, and it is not at all particular as to

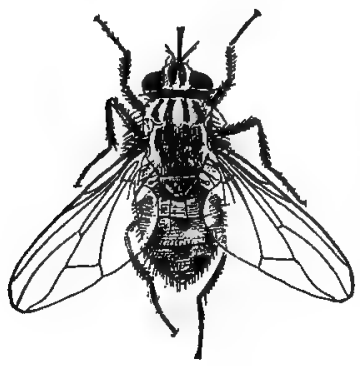

FIG. 77 .

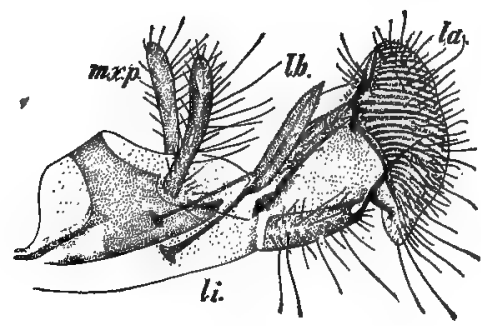

Frg. 78.

FIG. 77.-A stable fly. (Three times natural size. Kellogg.)

- FIG. 78.-Mouth parts of a house fly. (Kellogg)

what that substance is, generally the contents of slop pails, spittoons, or filth found elsewhere in places where filth is left exposed. The disease germs found in sputa of tuberculous persons, or the agents of putrefaction found wherever decaying matter is left lying in the air, are taken up on the hairy feet of these flies as they crawl about these places in search of food or to lay their eggs; and if their next visit is to your dining-room table where food is sitting, or to some abrasion in your skin, woe to you as to the possible results. (Fig. 79.) House flies undoubtedly spread infectious diseases by carrying the germs of those diseases in the filth which adheres to 
their feet. There should be as determined a crusade against the house fly as there is now being carried on against the mosquitoes. House flies are responsible for the spread of Asiatic cholera, typhoid fever, tuberculosis, and it may be proved that they have much to do with the carrying of diphtheria. (Fig. 80.)

The eggs of the house fly are laid in manure piles usually, or in some other decaying matter of even a more

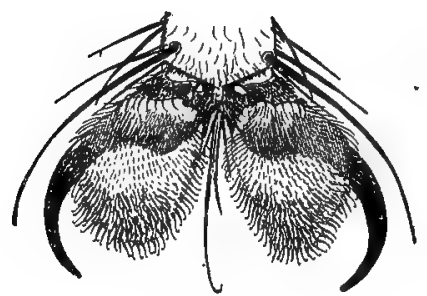

Fig. 79.-Foot of a house fly. (Kellogg.)

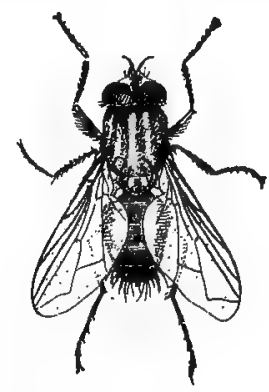

FIG. 80.-A house fly.

(Kellogg.)

repulsive nature. Each female lays about one hundred eggs. These eggs hatch in about six or seven hours, and the larvæ lie in the midst of abundant food supply for the five or six days of their larval existence; while in this stage they are minute whitish grubs, pointed at one end. The pupal stage lasts five days after this, and during this stage the fly looks very much like a brown seed. After the expiration of these five days the adult house fly emerges to go about houses to carry on the scavenger work and filth-carrying of its parents. Of course it is the juices of the compost heap that render it an attractive place for the fly to lay its eggs; and if that compost were spread upon the land to enrich it (as it 
should be to be most effective), the first step in the extermination of the house fly would have been taken. Then the second step would be the removal of all filth, including sputa in spittoons and on sidewalks and floors, and decaying garbage of all kinds; thus making the flies much less dangerous as disease carriers. Much of the danger which threatens us by way of the house fly is the result of our own carelessness and disregard of the laws of health. The stable fly, as has been said, often comes into our dwellings; and it may bite us after it has bitten some other animal infected with some disease, or after having crawled over some filth full of disease germs.

One of the notorious crop pests of the order is the hessian fly. The first heard of it was in 1778 ; hence it is an ancient enemy of American wheat fields, and if it were not for its natural enemies, wheat growing would soon become a thing of the past in the United States. As it is, conditions are bad enough, and natural as well as artificial means should be encouraged for the stamping out of this pest.

The fly is a little more than one-eighth of an inch long, with a pinkish or brownish abdomen, the remaining body regions being mainly black. The female lays her eggs in the lengthwise furrows of wheat leaves on the upper side. The hatching larvæ travel downward and work themselves inside of the sheath of the leaves and begin the absorption of the wheat sap. After a few weeks of this kind of feeding, the insects pass into the pupa stage familiarly known as the "flax-seed stage," because of the close resemblance of the pupa to the seeds of this plant. The adults, which soon come up out of the pupa cases, live only a few days, and during this short time the egg-laying is done for the second brood, which usually appear in 
August, and repeat the life cycle as far as the flax-seed stage, in which condition they pass the winter. Wheat stubble, therefore, ought to be ploughed under, or the standing stubble burnt off. Late sowing of winter wheat will be likely to deprive the second brood of a means of wintering over.

This insect attacks barley and rye also; and some observers record the fact that a third brood has been known to appear when conditions were unusually favorable. Among its insect enemies are four hymenopterous parasites; whose work is so well done that they are said to destroy nine-tenths of the aggregate number of hessian flies annually. If this is true, then even more than our wheat crops depend on soil and cultivation, they depend on these parasites, which we cannot see and would not know if we did see them.

The screw-worm fly is not so well known in the middle and northern parts of the United States, but in the southern states, especially in Texas, it is very troublesome. The adult fly lays its eggs on flesh, on manure, upon some open wound, or even on the mucous surfaces of domestic animals and the nasal passages of human beings. The larvæ, on hatching out in any one of the places mentioned, eat such foods as may be supplied by each source. In the case of the human being, they eat upward into the nasal cavities of the upper part of the face, causing great distress and frequently death.

Among the grass stem flies are the tiny Hippelates, the smallest of all flies. They are to be seen in summer weather about the eyes of cattle, dogs, and others of our domestic animals. In a recent epidemic of the "pinkeye" down in Florida, the germs of the disease were proved to have been carried by the flies of this genus. 
The pomace or fruit flies, or vinegar flies, as they are so often called, feed on decaying fruit or other vegetation which is over-ripe or decaying. A basket of pears may be attractive to these flies, not only as furnishing a meal, but also as a good place to lay their eggs. Their larvæ are often seen in poorly-sealed cans of fruit, in pickle jars that have been left open, or in brine barrels. Later their pupæ may be seen around the sides of the containing vessel just above the liquid. They often do damage to grapes on the vines.

About one-half of the dipterous families live in the water until ready to become adults, feeding upon vegetable matter probably and are supposed to do some good as scavengers. Of the remaining families, some pass the immature stages in the water, some on the land, while the remainder do not depend upon water at all for their development.

The most notorious of all the aquatic families is the mosquito family. Like all other dipters, the mosquitoes, some of them, have mouth parts adapted for lapping, while others have the piercing and sucking beak. Only the latter sort are important from the human point of view; and of the piercing and sucking sort only three genera, so far as present knowledge goes, are of importance to the human family, because of the relation they have been found to sustain to the spread of certain diseases. These three genera are Culex, Stegomyia, and Anopheles. To Culex belong the mosquitoes that keep up their shrill buz-z-z-z around our heads, stopping only to "take a bite." The mosquitoes of the genus Culex are the carriers of the disease known as filariasis. Some species of Culex, and the mosquitoes belonging to the genus Stegomyia, spread the yellow fever, The Anopheles 
mosquitoes are responsible for the dissemination of malaria.

All mosquitoes have aquatic immature stages. The eggs are usually laid in rafts, or flat packs, or in some species, singly, on the surface of ponds or pools or slowly-
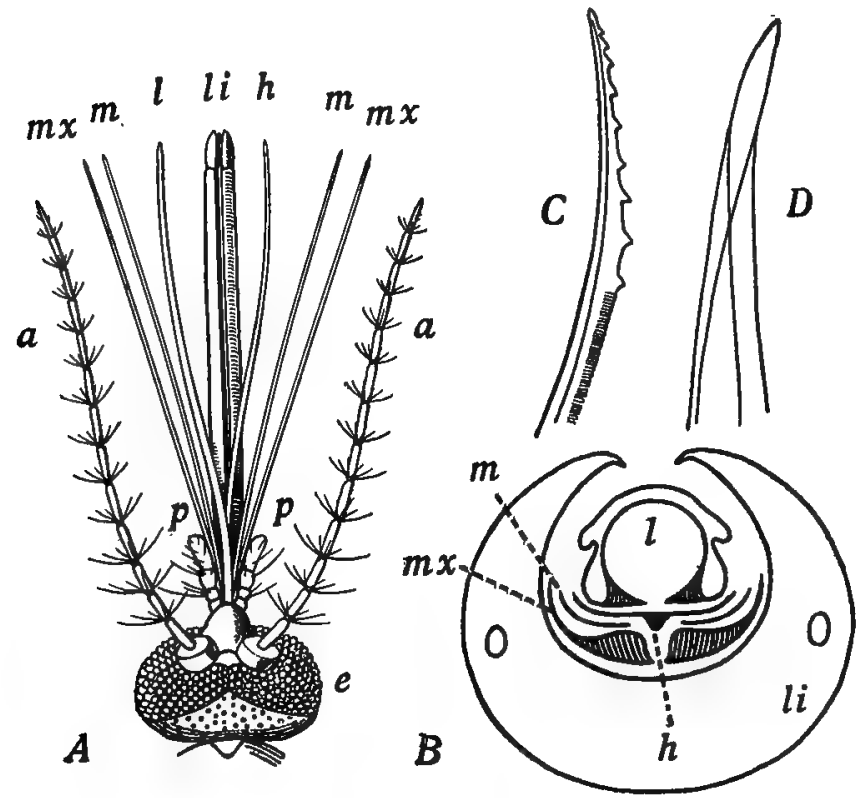

FIg. 81.-Mouth parts of female mosquito, Culex pipiens. A, dorsal aspect; $B$, transverse section; $C$, extremity of maxilla; $D$, extremity of labrum-epipharynx; $a$, antenna; $e$, compound eye; $h$, hypopharynx; $l$, labrum-epipharynx; $l i$, labium; $m$, mandible; $m x$, maxilla; $p$, maxillary palpus. (Folsom, after Dimmock.)

moving water, and hatch in from one to four days. The larvæ are the familiar wrigglers of the rain barrel or the neglected pool. The head is provided with two bunches of vibratile hairs and these, lashing about, keep a current of water constantly moving toward the greedy mouth, 
insuring plenty of food. The superficial opening of the respiratory system for the wriggler is in the posterior end of the body, the exterior ending of this tracheal system
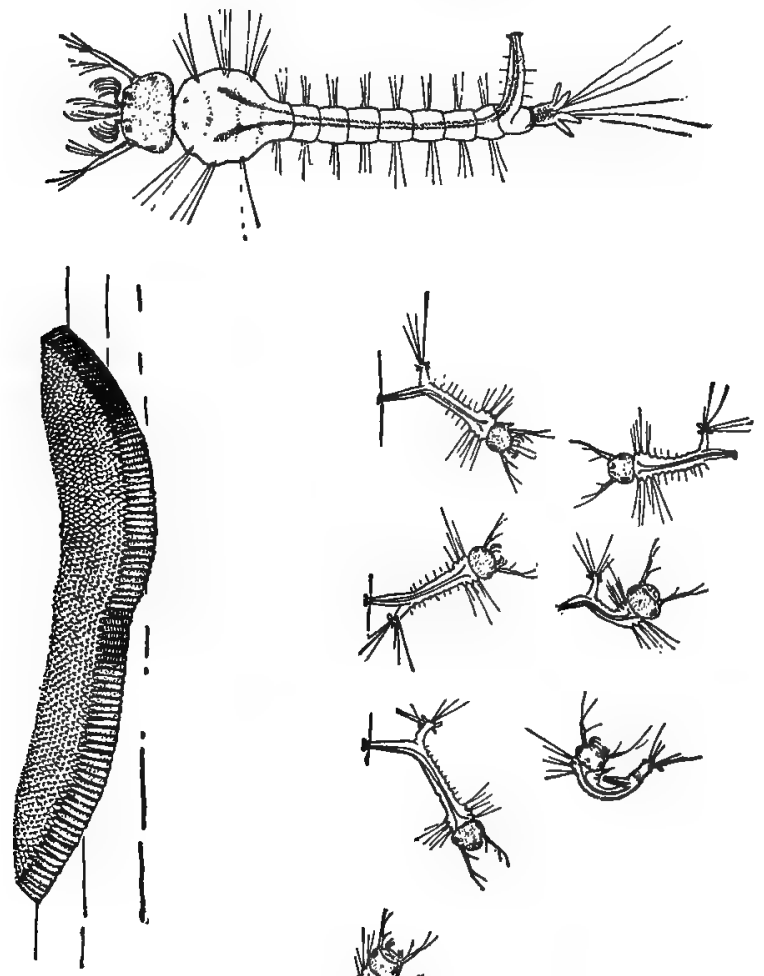

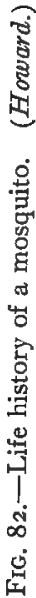
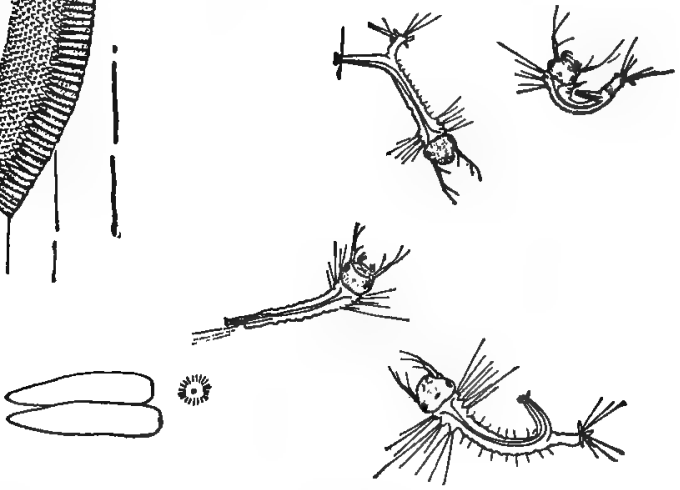

being the two-forked arrangement which you have seen so many times. The opening is closed by tiny flaps which fit tightly together while the larva is under water. 
When the air in the tracheal system is exhausted, the wriggler backs up to the surface of the water, holds on by the tension of the water molecules, opens up these tiny flaps, and breathes its tracheal system full of air again.

The larval stage lasts from one to four weeks or even longer, according to government investigations, depending upon the species, the season, and the varying conditions of food supply, temperature, water, and light. After the third moulting of the larvæ they appear as pupæ, each having a thick head end, which includes the slenderer, curving abdomen. Now the respiratory tube ends exteriorly by two tubes which arise from the upper side of the thorax. The pupal stage lasts from one to five days for the different species.

If you have been watching some standing water with some of these mosquito wrigglers in it, in the course - of time, many of these curved pupæ may be observed. They hang at the surface of the water and do not go below unless the water is disturbed, or they are frightened by some other means. Then they move downward with a curious jerking motion made by repeatedly flapping the slender abdomen against the big head end of the body. These pupæ are an exception to the usual pupal condition; they are non-feeding, as pupæ usually are, but they are very active. Most pupæ carry on their marvelous changes on the way to adulthood in some case or cocoon, hidden from our eyes and to all appearance motionless. But the mosquito "tumbler" lives alongside his younger brothers and sisters, in the same medium, breathing as they do, and gradually developing wings and long legs, antennæ and new mouth-parts, all the while being jostled about by numberless other creatures in their tiny ocean.

Soon after the first one of these "tumblers" appears, 
a little patient watching will reveal some of them turning into adults. The cast-off pupal skin may float on the water surface while the soft-bodied mosquito is sunning itself on some grass stem or bit of a leaf; or the young mosquito may sail on the tiny raft of its old pupal skin,

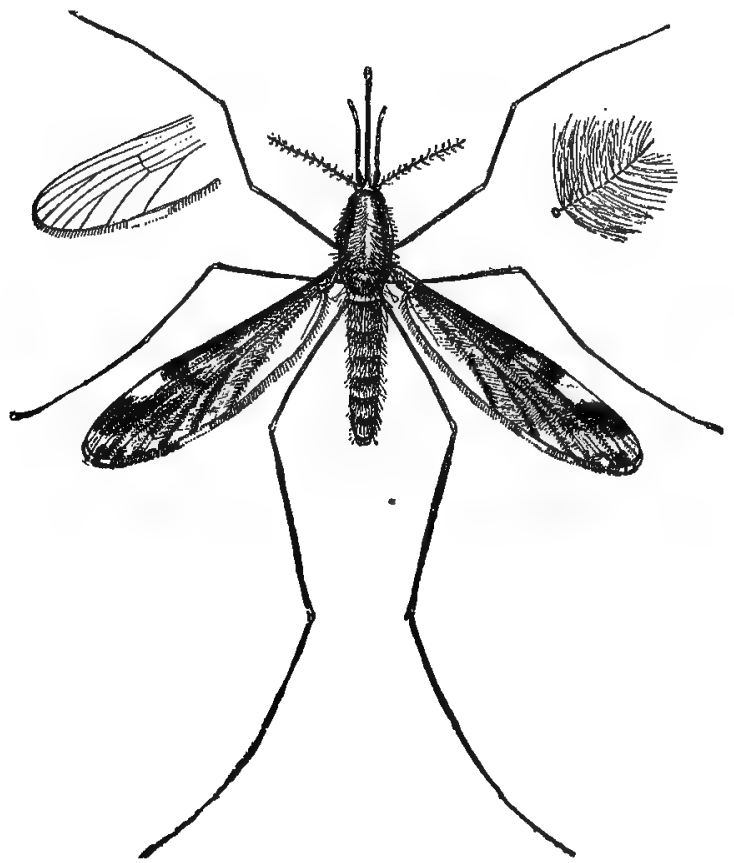

FiG. 83.-Anopheles punctipennis. Female, with male antenna at right and wing tip showing venation at left-enlarged. (Howard.)

while the wings are drying, its body wall hardening, and while it is taking the first draughts of air without water.

Mosquitoes have wings sparsely covered with scales, and in the genus Anopheles these scales are so arranged as to give an alternately light and dark appearance to the wings. (Fig. 83.) In Culex the wings are clear. Again 
the malaria mosquito lays its eggs singly, while Culex lays them in packs or rafts. In the pool which contains many of the wrigglers and tumblers, there may be seen some wrigglers which are coming up to breathe; some of them will be seen to hang at an angle of about forty-five degrees, while others will rest nearly parallel with the water surface above them. The latter are the Anopheles or malaria mosquitoes, and the forty-five degree wrigglers are the Culex.

While it is true that there may be mosquitoes present where there is no malaria microbe, and vice versa, the only safe course to pursue is to kill off the mosquitoes already hatched, and to destroy any possible breeding-places. It has been proved that the malarial parasite can complete its life round in some species of birds, but an Anopheles mosquito, biting first such a bird, and second a human being, might thus transmit the disease from the bird to the human being. The malarial parasite enters the digestive canal of the mosquito through its biting some infected person, breeds in the intestines, passing finally by the blood tract to the head and neck region, where it collects in the salivary glands. When such a mosquito bites another person the saliva from these glands injected into the wound made by the stylets, carries with it numbers of the parasites, which are at that time ready to enter upon the next stage of their life history in the body of the human host.

Except in a very few cases, the male mosquito has long feathery antennæ, the feathery appearance being due to the auditory hairs which cover the antennal joints thickly. The female mosquito has antennæ with fewer and shorter hairs. The male mosquito, where he eats at all, eats vegetable food; most of them live a much 
shorter life than do the females; some have little-developed mouth parts and presumably eat nothing at all.

As to the hibernation of mosquitoes, some species pass the winter in the adult stage, other species in the egg stage, and still others as larvæ; none is actually known to winter over in the pupal stage. Observations show that mosquito larvæ are strongly resistant to cold, some
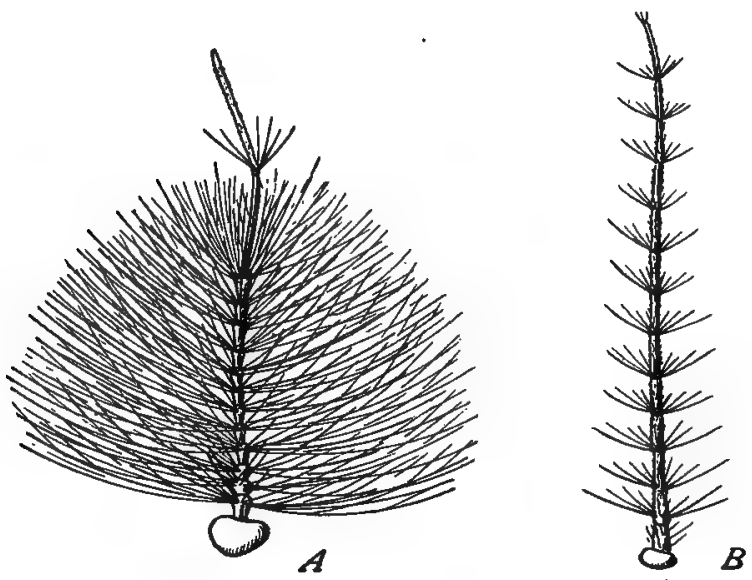

FIg. 84.-Antennæ of mosquito, Culex pipiens: $A$, male, $B$, female. (Folsom.)

being able to freeze repeatedly and yet survive. The larvæ live mainly on decaying vegetable matter and living algæ; though some of them are carnivorous, eating other animals in the pond, smaller than themselves. Practically all mosquito breeding goes on in waters where there are no fish; as the mosquito mother, probably obeying the self-preservative tendency of its ancestors to lay its eggs in situations as free from dangers as possible, usually deposits its eggs in some pond or stagnant pool. One species of Culex prefers to deposit its eggs in 
some hollow in the ground where the water stands only occasionally, and where the eggs will hatch in installments. Another species of mosquito deposits its eggs singly; the eggs sink to the bottom of the pond, where they remain till the following spring before they hatch. Government experts tell us that the normal food of adult mosquitoes is probably plant juices, and that the taste for blood is probably an acquired habit. If that is true, we certainly have reason to be thankful that the bloodsucking habit is confined to the females of our dangerous mosquitoes.

Small fish are by far the most important natural enemies of mosquitoes. The carnivorous minnows, the sticklebacks, the sunfish, are all efficient destroyers of the larvæ in permanent pools of water. The common gold fish does good service in similar places. Aquatic insects, such as the water scavengers, the diving beetles, dragonfly larvæ, all are valuable allies of man in getting rid of immense numbers of eggs, larvæ, and pupæ. Adult mosquitoes are devoured by bats, night-hawks, swallows, martins, and flycatchers, as well as by the adult dragon flies. These last-named seem to have special preference for a mosquito diet, for which we ought to be so thankful that we would never kill a dragon fly. needlessly. It is said that the streets and houses of Honolulu would be practically uninhabitable if it were not for the dragon flies that hunt the mosquito swarms constantly (Kellogg).

Mosquitoes in the adult stage are also attacked by certain fungous diseases similar to those which attack our house flies, and leave their bodies mere shells, filled with the hyphal growth of the plant.

On the part of man in the attempt to destroy these disease carriers, the first step is to drain every pool or 
pond, and empty every rain barrel or other vessel which might serve as a breeding-place. If draining is impracticable, covering the surface with a coating of oil will kill the larvæ and the pupæ. They are air-breathing animals, and the oil film makes it impossible to get air to breathe; they drown as you and I would if we were shut off from air. Good ventilation will usually disperse large numbers of them, which have the habit of collecting about dwellings, porches, area-ways, and other sheltered places. Mosquitoes are not strong on the wing, and a stiff breeze often sweeps them out of their course. This is especially true of Anopheles, the malaria disseminator. Anopheles and the semi-domestic species, Culex pipiens, have limited powers of flight and so must breed close to their feeding-places, two hundred yards, in some cases twenty-five feet will be found to be their limit. Adult mosquitoes vary in their feeding habits; some fly only at dusk, some fly almost all night, hiding in dark places or at the bases of rank-growing grasses during the day; and still other species may be found abroad in the daytime.

As to the good qualities of the beneficial fly families, much more might be said than there is space for

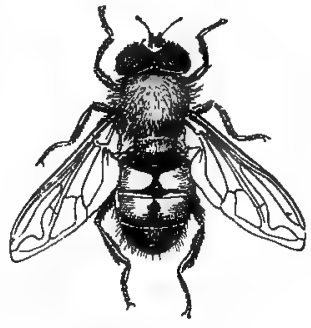

Fig. 85.-A Syrphid or flower fly. (Kellogg.) here. To them we are indebted for the destruction of large numbers of wood-boring beetles (midas flies); of grasshoppers (bee flies and wasp flies); and the pollenation of many plants (flower flies or Syrphids). (Fig. 85.) The Tachina flies deserve special mention here. They are rather heavy-bodied flies, with hairs generally more numerous and longer than the hairs on the house fly's body; though 
they resemble the house flies in the gray tints of the body and in the buzzing sound with which they fly, though the buzzing is not so pronounced in the case of the house fly. This fly family, Howard, the government entomologist, tells us, is the most beneficial of all the fly families, and the benefit conferred by them enormous. The Tachina flies make short work of a brood of army worms by laying their eggs in the juicy bodies, and the Tachina larvæ do the rest. They also attack grasshoppers, saw flies and saw fly larvæ, bugs, beetles, and wasps by the same sure parasitic means. Any big-bodied, dark-colored fly with bristling, stiffish hairs, rather sparsely scattered over the surface of its body, is fairly sure to be a Tachina fly, and should be carefully let alone; and, if it by any chance gets into the house, it should in due time be turned out of doors where it may freely carry on its good work of getting rid of harmful insects.

The Syrphids are the flies that rival the Tachinas in point of usefulness to man. The larvæ vary in their feeding habits, but most of them are useful in this stage; some of them feed upon plant lice, some upon decaying plant and animal remains. In the adult stage they are the flower pollenators. The drone fly that comes into the house in the late summer is one of these Syrphids. It much resembles a bee in appearance, hence its name. Its maggot is the rat-tailed larva so often found in mud or excrementitious matter. They are all conspicuous flies, with some bright markings on the body, usually yellow; and often metallic in color, or green with black bandings.

Of these two fly families, all the members are beneficial; of some of the other flies mentioned in the beneficial list there are some that would be rather on the "half- 
way" list. Such a family is the family of the robber flies. They are entirely predaceous, fiercely so; and as long as they prey upon injurious insects, all well and good; but when they pounce upon a bee, a tiger beetle, or a dragon fly they are decidedly injurious. They also eat many smaller flies, and the chances are that such flies are better dead than alive. The robber flies are swiftly-flying insects, pointed as to the abdomen; the legs are long and strong and the claws are prominent and set nearly at a right angle with the tarsi. The long-legged flies are much slenderer flies, with long dangling legs which get tangled up as their owners fly uncertainly short distances, and sit down frequently, as if tired of managing such difficult things. They eat smaller flies and gnats.

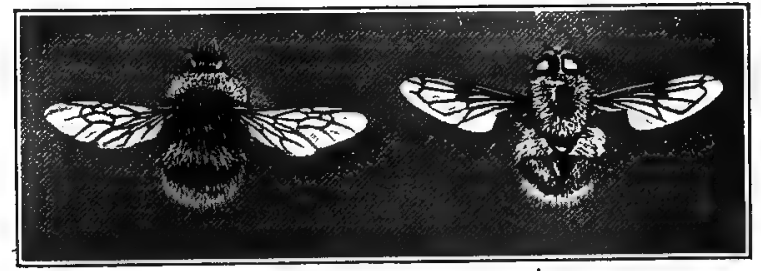

FIG. 86.-Aggressive mimicry. On the left, a bee, Bombus mastrucalus; on the right, a bee fly, Volucella bombylans. (Natural size. Folsom.)

The wasp flies are exceedingly like wasps in body form and coloring, but possess only two wings. They are all flower pollenators, and in addition to this their larvæ are parasitic, thus conferring a second benefit.

The soldier flies have slender legs, often variously shaped, some having the femora and the tibiæ flattened or spinose or scaly. Most of them look hump-backed because of the thorax' being very convex on the upper side, the neck, where it joins the head to the thorax, 
also being very slender. The beak stands out straight in front of the head, and their prey, smaller flies, they impale upon it.

The bee flies have rather heavy bodies covered with soft hairs, and look much like bees, even to the colors in some species. (Fig. 86.) The adults are flower pollenators; and in eating the pollen assist in carrying it about on their hairy bodies, thus accomplishing cross-pollenation for many plants. Their larvæ are parasitic upon the eggs of several kinds of insects, especially locusts.

It may seem, from the fly families mentioned, that the order suffers a reputation which it ill deserves; but hardly so. The one family, Muscidæ, the house fly family, is the most numerous order, and includes pests enough to put the work of the beneficial flies in strong contrast, if not to outweigh it. 


\section{ODONATA.}

\section{CHARACTERISTICS.}

\section{Dragon flies.}

I. Four gauzy, shining wings of about equal size.

2. Body strong, long, and tapering toward tip of abdomen.

3. Compound eyes large and prominent.

4. Flight zigzag, swift, and long-continued.

\section{Damsel files.}

I. Same as for dragon flies but on a much smaller pattern. 



\section{CHAPTER XIII.}

\section{ODONATA.}

This is the order of the dragon flies and the damsel flies, the fiercest of all predaceous insects, preying upon other weaker insects, and upon the weaker members of their own kind in the larval stage; and even in the adult stage the weaker occasionally furnish a meal for the stronger. The damsel flies are the narrow-winged dragon flies, and are more nearly strictly aquatic, usually flying only short distances above the pond or river and not making long excursions away from the vicinity of their water haunts. Dragon flies fly higher over the water surface, or into fields and sunny places generally; a few species have a liking for the neighborhood of dwellings.

All dragon flies have four strong wings, and the pairs are nearly alike in size. The body is slender, smooth, and cylindrical or tapering. Their flight is strong and long-sustained, and the wings are built to stand this strain. The subcostal vein of each front wing is placed at the bottom of a groove, and the short cross-veins in that groove are enlarged vertically so as to form effective braces. About two-thirds of the way out to the tip of the wing, there is a notch or node in the front margin of the wing; and at or near this notch, there is usually a dark spot called the pterostigma or wing mark. In some of the species the wings are clear of other markings, but in other species the wings are crossed by various bands or spots of color. In the male of the Black Wing, the dark 
color suffuses the whole wing. In the damsel flies these colorations are often bright green, blue, or red. The iridescent gleam from the wings of a living dragon fly is probably due to the refraction of sunlight from the minute blood drops mingled with air, as this fluid circulates through the delicate double sac forming the wing, thus refracting the light components of different length, giving corresponding color impressions. These colors fade in death and the wing seems uniformly colored or colorless.

The wing movement in flight is a figure eight performed by the wings acting separately. These are the insects which have the tracheal pockets reinforcing the usual tracheary tubes of the respiratory system. They do not fly so high as do some of the butterflies; nor do they make migrations as do some of the lepidopters, but their flight is much stronger, they can go much longer on the wing, and they hunt their prey exclusively from on the wing. The Odonata, both immature and adults, have strong mandibles and maxillæ for seizing their prey and tearing its flesh in pieces.

The head is unusually large, more than two-thirds of it being made up of the compound eyes. There are more than thirty thousand facets in the compound eye of a dragon fly; that means more than thirty thousand parts in the mosaic of yourself when the dragon fly looks at you. And with the Odonata as with the Lepidoptera, the finer the mosaic, the better the image. Indeed you will find it very difficult to catch a dragon fly off its guard. You may be obliged to steal upon it from behind, and then feel ashamed for killing an insect so intelligent and so beneficial in every way. Dragon flies have a special fondness for flies and mosquitoes, and they also devour wasps. If you are ever sneaking enough to catch one late 
in the afternoon, on his way home, you will usually find his mouth full of flies, so full that he has not yet had time to stop to chew and swallow them. The prey is caught by the six slender legs, and then held by the front. legs while the insect devours it.

It is a curious fact that, with the draining of the ponds and streams for the extermination of the harmful mosquitoes, has come a decrease in the number of dragon flies. If these dragon flies ate only mosquitoes, this would not be a serious matter; but the large service which dragon flies render in eating flies, gnats, and moths, puts another face on the situation. For several years, since 1895 , in fact, there has been an organized crusade against mosquitoes, and it has been quite successful in ridding the land of large numbers of these pests. But the house and the stable flies constitute an even greater menace to the health of human communities as well as to lower animals, and chiefly because they are a tolerated nuisance; and for that very reason, dangerous in the extreme. It would seem, therefore, that the loss of any insects that prey upon flies would be productive of an increase in disease among human beings, unless direct measures were taken against the breeding and domestic harboring of these pests. Stock-breeders pay more attention to the attacks of bot flies and horn flies than do human beings to the insidious approach of the disease-carrying house and stable fly in our homes, living-rooms, sleeping-rooms, and dining-rooms. Whether this decrease in the number of dragon flies will result in disturbing noticeably the balance of nature remains to be seen.

The development is with incomplete metamorphosis, the larval stage being greatly extended and the pupal stage lacking. The egg-laying is accomplished usually 
while the female is on the wing. The female poises just above the surface of the water, occasionally dipping down as an egg is discharged; or from her flight-she swoops down at the instant of depositing the egg. The eggs are, by some species, deposited free in the water, while others deposit them in the stems of water plants, the slit in the stem being made by the sharp ovipositor. The time of hatching of the egg varies with the species and with the

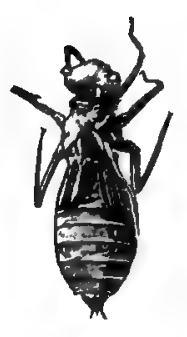

$A$

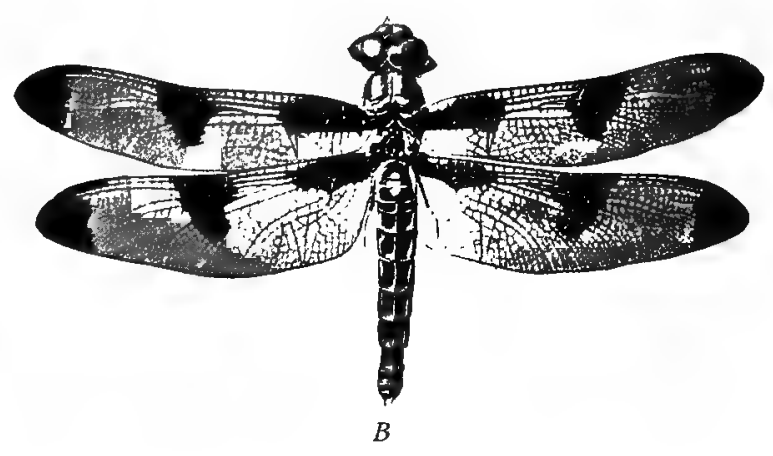

FIG. 87.-Stages in development of a dragon fly, Libellula pulchella. A, last nymphal skin; $B$, imago. (Slightly reduced. Folsom.)

season of deposit. The eggs of some of the dragon flies, laid in midsummer, hatch in a few days, six to ten, while eggs laid in autumn do not hatch until the following spring.

From the eggs hatch tiny nymphs with slender legs, thin bodies, and no wings, of course. These nymphs are aquatic throughout their long life; hence their respiratory system is adapted for breathing under water, being a curious internal modification of the alimentary canal at the anal end of the body. Their food consists of other forms of aquatic life, mosquito eggs, larvæ, pupæ, and 
adults; May-fly nymphs, some weaker nymphs of their own kind, and aquatic worms.

Some dragon-fly species do not attain their full size under a year, while others reach adult size in a few months. The nymph comes to maturity by frequent moultings; the exact number of moults is not known, but an old nymph may be known by its size and dingy color. Just before each moult, the colors are uniformly dingy brown, while the new nymph will be a brighter color, usually greenish; and. when it approaches maturity it will approximate the size of the adult dragon fly.

If you are fortunate enough to live near a pond, go down to it some warm spring morning or morning in the early summer, and you may be lucky enough to see some dragon fly making its final moult. Here it comes, a clumsy, big-headed thing, dragging itself up out of the water on to a grass stem or on to the mud at the water's edge. It sits still in the sunshine while its old nymphal skin dries and cracks along the back, and out of the rent there begins to appear the adult insect, shoulders first, and head afterward. After considerable maneuvering it is finally free, and you see a wet-skinned, soft-bodied dragon fly, with its big wings wet and wrinkly and yet lacking the brilliant colors. It may take. a good share of the forenoon to dry. Drying means the hardening of the chitin in its body wall; and in its wings the chitin ribs must dry before the insect can perform its wonderful feats of flight. The colors gradually come out as the body dries, and possibly while you are looking, the shining wings expand and off sails the insect on its maiden flight, for its first breakfast on land.

The old nymphal cases, or exuviæ, may be found around the water's edge, or you may rake them out as you 
poke about for water beetles or aquatic bugs. They are thin, translucent cast-offs of various sizes, according to the age of the nymph which crawled out of them. The wall material is chitin, and they will remain in the water a considerable time before they will suffer distintegration; chitin serves its purpose well as a body covering, andwears long before it suffers injury from any cause. Though it usually suffers decomposition in water after the lapse of a year, it is much less affected by acids than it is by water.

About three hundred species of dragon flies are known in the United States and adjoining countries; two thousand in the world. The great majority prefer warm localities, although Kellogg records some as having been found as high as ten thousand feet altitude, and as far north as $63^{\circ}$ in Siberia, $65^{\circ}$ in Alaska, and $76^{\circ}$ in Norway. 


\section{CHAPTER XIV.}

\section{EPHEMERIDA.}

This is the order of the May flies, curious gauzywinged creatures to be found in the neighborhood of ponds or streams, where the sunlight falls, or near the electric lights, if you are on the lookout for "sights." The body of the adult May fly is extremely frail; the wings are made of the finest gauze stretched over a framework of delicate veins. The front wings, when all four are present, are much larger than the hind wings; and the hind wings, in some species, are greatly reduced or wanting. There is very little of chitin in the body walls, hence the powers of flight are slight, and the insect lacks fighting qualities, the qualities which always make for the individual in its struggle for survival in a world filled with other living beings. The insect is so weak in the adult stage that about the only explanation of its persistence seems to be: first, the greater strength and assertiveness of the insect in its immature stage; and second, the fact that the reproductive energy of the adult is discharged so soon after the last moult.

In the female the legs are weak, while in the males it is only the hind legs that are weak. The abdomen of both sexes usually bears two or three stiffish bristles at the caudal end. The head has compound eyes and short antennæ; some species are provided with weakly-developed mouth parts, but in most May flies the mouth parts are 
so little developed as to be of no use. Eating seems hardly necessary during the extremely short adult life.

The metamorphosis of the May flies is incomplete. The eggs issue from the egg glands in packets, as the swarm of adults zigzags about over the surface of the
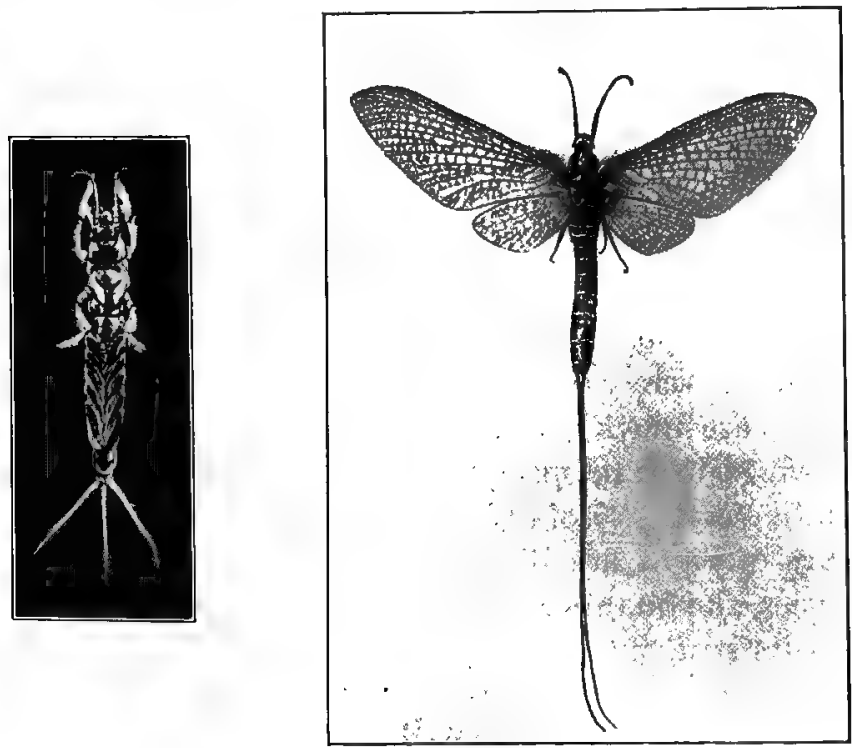

$A$

$B$

FIG. 88.-Nymph and adult of a May fy, Hexagenia variabilis. $A$, nymph; $B$ imago. (Natural size. Folsom.)

water. From the eggs hatch tiny nymphs without wings or wing pads, and looking very much like the most primitive of living insects. These nymphs crawl about over the bottom of the pond, eating any acceptable food that may offer, possibly feeding on other animal life. The mouthparts of the nymph are adapted for biting 
and chewing; and the larvæ seem well able to protect themselves, being able to act on the offensive as well as being warily defensive. During this stage the insect fares as well as do most other insects; it is only in the adult stage that the insect is peculiarly a weak insect. Finally, at the end of a year, or two or three years for some species, the nymph is ready for the last moult. It breathes while in the water by means of flat, leaf-like gills, extending into the water from either side of the body along the entire abdomen and in some species from the thorax also. Some very young nymphs are without these lateral appendages, and seem to make the exchange of carbon dioxid for oxygen through the delicately thin body skin, which is at that time without chitin.

Having reached the adult nymph stage, the old nymph floats to the water surface, or crawls out onto the bank, begins to dry, the skin splits, and out comes the adult May fly. Others appear in rapid succession, so that there is soon a swarm of these delicate creatures; then all join in the whirling dance over the river surface, or under some electric light if there is one near. If the swarm belongs to the short-lived May flies, the mating occurs during this dancing flight, the females drop their egg packets, and soon flutter after them and fall into the water, the frail adult life over and done before the coming of another sunrise. It is because of the shortness of the adult life of the most of the species that the name of the order is given. Ephemerida is made of the Greek preposition 'ephi, meaning during, and the Greek noun éméra, meaning a day.

No May fly, so far as known, lives beyond the third day; and three days is an unusual period, the majority of our May flies living only a few hours. With some few 
of the May flies, a moulting occurs after acquiring wings; this is called a subimago stage, and is a phenomenon not known to occur elsewhere. This stage may last from a few minutes to twenty-four hours. Such unusual extensions of the adult stage as are known to occur, seem to have relation to this subimago stage, the adult life of the different species after this subadult moult is undergone, being nearly uniform in length. 


\section{CHAPTER XV. PLECOPTERA.}

This is the order of the stone flies. In the same water with the May flies, possibly, but where the water runs swiftest, may be found some nymphs that look very much like the May fly nymphs, but the bodies are flatter and darker, and show some light and dark stripes. These are the stone-fly nymphs, and they cling to the under side of stones, whence their name. They cling where the water current is swiftest, but when pursued, they run very swiftly, and disappear under other stones with amazing rapidity.

The nymphs breathe by means of thoracic gills, one tuft of filaments or one single filament to each leg. The remains of these gills may be seen in the adults of some species. The feet of the stone flies are provided with two claws, while the May flies have but one. The larvæ, so far as they have been observed, are active and well able to defend themselves. They are carnivorous as to food habits, with strong biting mouth parts, the same as the adults. The number of eggs laid by the females is enormous, seeming to indicate that the larvæ must take many chances of being eaten; and this is true. For, although the nymphs are better able to protect themselves than the May-fly nymphs, yet great numbers of them are eaten by various enemies, fish, dragonfly nymphs, and water birds.

The body of the adult stone fly is rather long and flattish, and soft-walled. Its wings are membranous, but the hind wings are larger than the front wings; and 
when the insect is resting on some grass stem, the hind wings are plaited and the front wings lie flat on the back. The antennæ are thread-like and reach far out in front of the head.

None of the stone flies has a well-known life history. They seem to reproduce by a metamorphosis much like that of the dragon flies. Their food habits are not

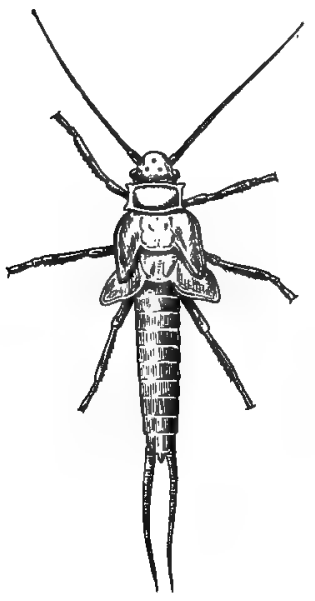

A

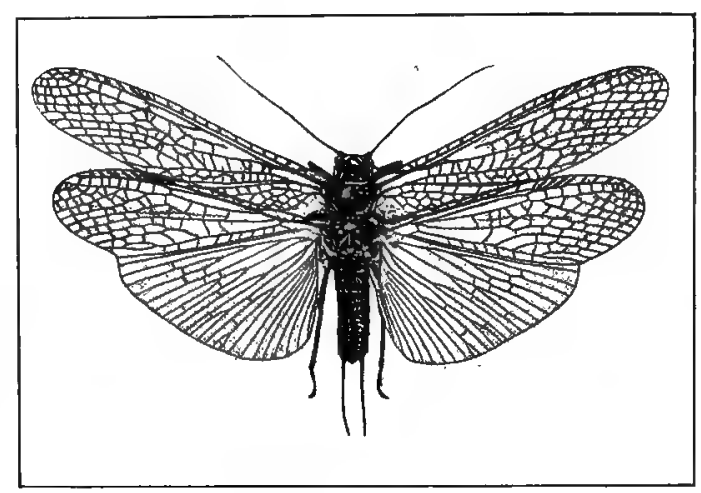

$B$

FIG. 89.-Nymph and adult of a stone fly, Pteronarcys regalis. $A$, nymph (after Newport); $B$, imago. (Slightly reduced. Folsom.)

certainly known; they probably eat other forms of aquatic life; but some observers who have made a somewhat extended study of them, say that they also seem to be scavengers, eating decaying organic matter. Small stone flies are less than one-fourth of an inch long, while the larger species are two inches long. Here is a field for investigation for someone who likes to be much in the open, and who is in sympathy with life in its manifold phases and activities. 


\section{NEUROPTERA.}

\section{CHARACTERISTICS.}

I. Wings four, many-veined, sometimes spotted with contrasting colors. The main vein of the wing is usually some distance from the front margin of the wing, and the space is crossed by many oblique, parallel veins.

2. Mandibles strong; in the male sometimes enormously enlarged.

\section{False Rear Horses.}

I. Wing-covers usually shorter than the abdomen and bending around it, not lying flat on the back as in the praying mantids.

2. Front legs much larger than the other two pairs, and used for seizing the prey.

3. Prothorax long and slender; the front pair of legs fastened well forward at its front, so as to bring them close up to the head. 



\section{CHAPTER XVI.}

\section{NEUROPTERA.}

In the order as first established by Linnæus, were included the May flies, the dragon flies, the caddis flies, and some other insects to be mentioned later. At present, the May flies, with their flat, external abdominal gills, form the order of the Ephemerida; the stone flies, with their filamentous, thoracic gills, their ocelli as well as compound eyes, and their inability to live in stagnant water, form the order Plecoptera; the dragon flies, with their internal rectal gills in the larval stage, their peculiar aerating system, and their strong adult wings, form the order Odonata; the caddis flies, or caddis worms, after their more familiar larval appearance, form the order Trichoptera; while the lace-winged flies, the dobsons, the ant lions, and the scorpion flies are left to make up the order Neuroptera.

All the insects of the order have net-veined wings, strong mouth parts, either for biting or piercing, and a development by complete metamorphosis. So far as known, the members of the order are carnivorous in their feeding habits, and many of them are aquatic in the larval stage. The snake flies, rather rare insects with the prothorax slender and curved, making them look humpbacked, feed largely upon the larvæ of the codling moth, one of our worst apple-tree pests. The aphis lion, in its larval stage, crawls about over the surface of plants infested with plant lice and makes short work of them. Later in the summer, 
there will possibly be found the eggs of some aphis lion on the leaves of some louse-infested plant. Always on the upper surface of the leaf or stem, and standing on slender, swaying, translucent stalks, the greenish eggs look curious enough. (Fig. 90.) The reason for the plac-

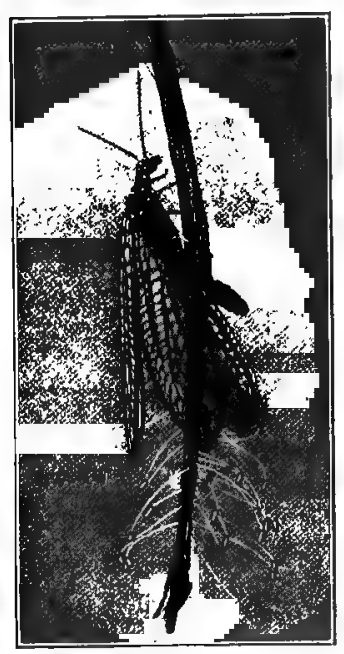

FIG. 90.-A lace-winged fly, Chrysopa, laying eggs. (Slightly enlarged. Folsom.) ing of the eggs in such a situation is plain enough when one finds out by watching that the young aphis lion is fond of an egg diet, prefers it to anything else, and the egg containing his brother or his sister tastes quite as good to him as does any other egg. The aphis lion mother, instead of trying to break up the egg-eating habit, simply builds a stalk for each egg, and glues the egg fast to the top of it. The young aphis lion "upon hatching out, crawls down to the leaf surface, and goes off to seek for other eggs for his meals, all unconscious of the rich feast so close at hand.

The adult aphis lion is a beautiful, lacy-winged fly, with greenish body and delicate white wings with iridescent hues shimmering from them at every turn of the owner. The eyes are large for the size of the adult, and, while the lace-wing is alive, are bright golden in color; for this reason the lace-wing is often called the Goldeneye. The adult probably has similar feeding habits to those of the larva.

The larvæ of the dobsons are well known to fishermen 
in the eastern states, and they are occasionally found in ponds in the West. The adult form is the form more commonly found, however, because the small boy in the West more often uses angleworms for bait, and so does not discover the dobsons till later in life. The adult has a wing spread of more than four inches, the wings are translucent with veins showing quite plainly, and irregularly spotted with light and dark. The hind wings are larger than the front wings and are enlarged considerably at the angle next to the body; hence, when folded, they are somewhat plaited, while the front wings lie flat above them.

The dobsons have a very long immature stage, two years and eleven months, all spent in the water, hunting fiercely for May fly and stone fly larvæ. The pupal stage covers another month; hence the insect consumes three years in growing to adulthood in size and power. The insect having the longest immature

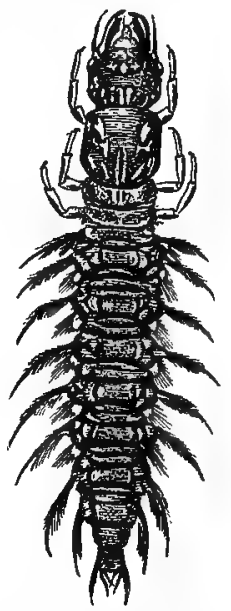

FIG. 9I.-Larva of a dobson. (Kellogg.) period is probably the seventeen-year cicada, which remains in its underground burrow, feeding on plant roots, for seventeen years. The male of the dobsons has the mandibles developed into long curved organs standing far out in front of the head; in the female the mandibles are less prominent. (Fig. 92.)

Here also are to be found the false rear horses, insects much resembling the praying mantids among the Orthoptera. Their long front legs, by which they catch their prey, look very much like the queer "hands" of the praying mantis when he perches on your magazine cover and 
looks solemnly at you; and the rear horse is quite as bloodthirsty as the mantis. The front part of the thorax is drawn out into a slender, stick-like segment, and on the front end

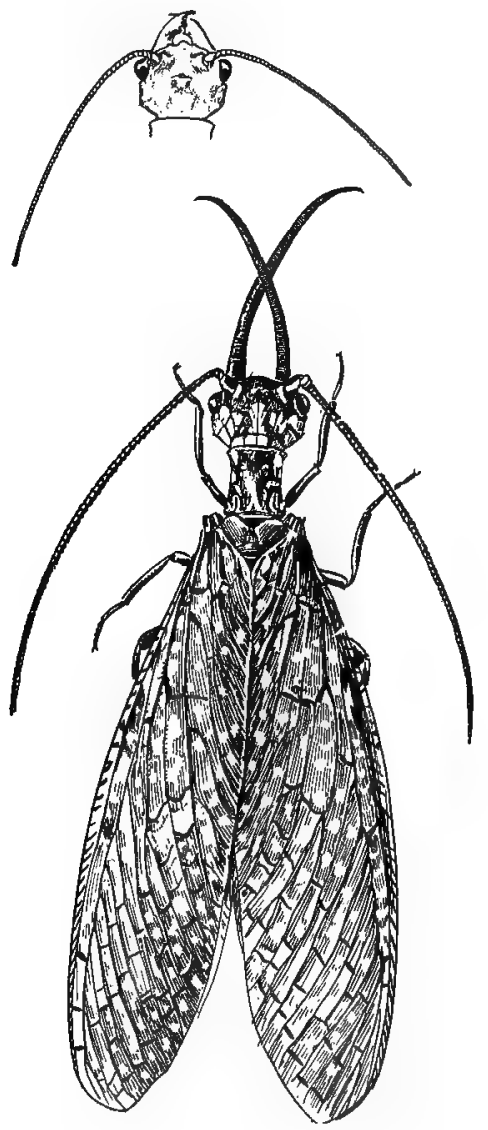

Fig. 92.-Adult dobson, with head of fernale above. (Kellogg.)

of this are placed the big, grasping front legs. This gives the insect the queer appearance of having its front legs fastened to its small head. The other two pairs of 
legs are bunched at the further end of the thorax near the abdomen. (Fig. 93.)

The ant lion is one of the most interesting members of the order while it is in its larval stage. The adult ant lion lays her egg in the sand; and the larva, immediately upon hatching, digs for itself a pit in the sand, hollowing it out carefully and smoothing off the sloping sides. Then it carefully digs under at the bottom of this pit, leaving nothing of itself visible except its head and

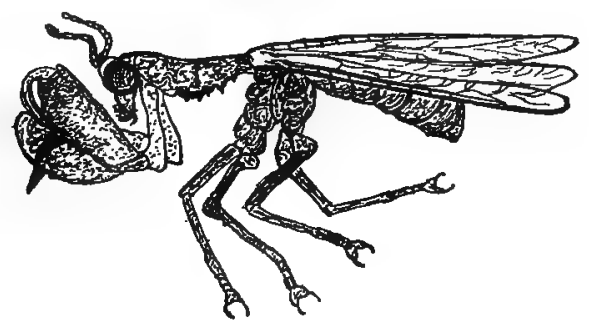

FIG. 93--A false rear horse or mantispa.

sharp jaws. There it lies, quietly, but keeping sharp watch; and when an ant comes scurrying along with some big burden, intent only upon getting home, over it goes into the pit, the treacherous sand giving way under its feet. After many more meals of the same kind, the old larva hollows out for itself a burrow in the sand, lines it with silken threads, and there pupates. The adult has four membranous wings, thickly crossed with veins and usually more or less spotted with brown or black.

All of the members of the order are valuable insects, feeding upon other insects which are harmful; hence none of the order should be carelessly hunted, nor killed without good and sufficient reason. 


\section{CHAPTER XVII.}

\section{SIPHONAPTERA.}

This order includes but one class of insects, the fleas. By early entomologists, the fleas were classed as a family of the Diptera, on the ground that they were structurally flies that had lost their wings through a process of degeneration, growing out of an increasing habit of parasitism. But their structural differences are now known to be so great that they are made to occupy an order by themselves.

They are parasitic upon mammals and birds; hardly any warm-blooded animals are exempt from their attacks. The order, at present, consists of but a single family, the Pulicidæ. The insects are wingless, and have piercing, sucking mouth parts. The body surface is heavily chitinized and smooth, but is regularly set with spiny hairs. The body is much flattened vertically, a fact that makes it easy for the insect to pass readily between the hairs of the dog, cat, or bear host, and also makes it difficult to catch them.

Among the most curious of the Siphonaptera are the jigger fleas, insects more common in warm countries than in our own latitude. The male jigger flea is winged, and leaps on or off the body of the host; but the female lives on the body of the host nearly her entire lifetime. When the female is ready to lay her eggs, she burrows beneath the skin of the host, which may be one of the lower animals 
or a human being. The body of the female, congested with the egg burden, bursts in the burrow thus made, and the larvæ hatching from the eggs feed upon the blood of the host until the time for pupation. This period is also passed through in the burrow underneath the skin of the victim; and the adults emerge through the festering wound to seek new places where they may make new burrows and rear new jigger flea families. Oftentimes, the irritation incident to the rearing of these jigger flea families is sufficient to cause the death of the host. This flea is not to be confounded with the chigger of our western plains and lawns. The latter animal does not belong to the insects at all, but is one of the mites, has eight legs instead of six, and a differently-segmented body. It ought to be noted here that the female of the hen flea also burrows beneath the skin of the host, and the eggs are laid in the small tumor that forms around the body of the insect.

The Siphonaptera include also the human flea, the dog and the hen flea, and the fleas infesting so many of our wild mammals, also birds and domestic animals. These fleas are parasitic only during the adult stage, and then mainly at meal time.

The eggs of the dog flea are laid between the hairs of the host, from whence they drop to the ground and hatch among the refuse and dust. The larvæ seem to feed on organic matter, though they are more adaptable than most other insects, being able to develop on other food, such as dry plant remains, epidermal scales from the body of the host, and possibly excrementitious matter from adult fleas. Some fleas have been reared artificially on dried crumbs or dried blood. The time of development of fleas ranges from less than two weeks to consid- 
erably more than two weeks in different species, though for the majority of our native fleas, the time of development is about two weeks.

The eggs of the human flea, Pulex irritans, are laid in the house around the edges of the carpet or in the cracks
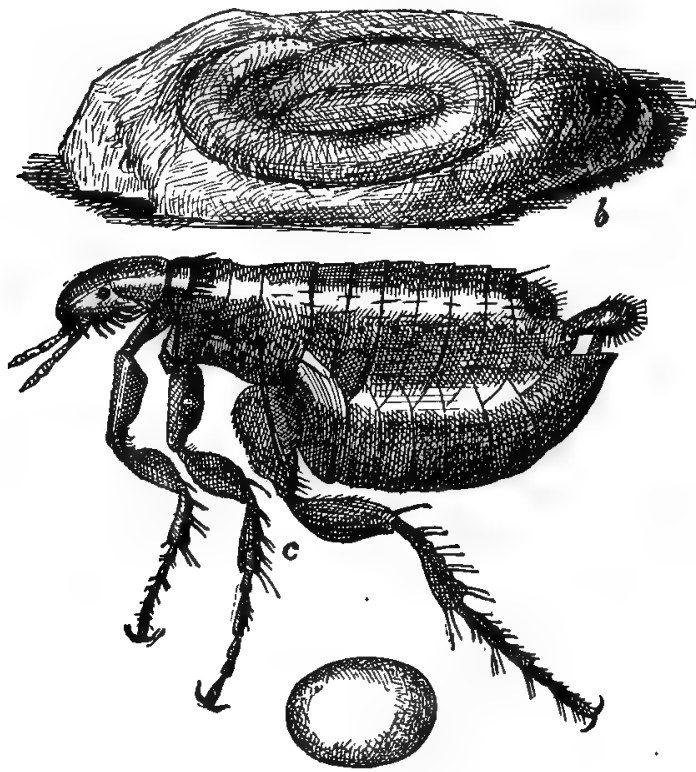

FIG. 94.-Egg, pupa, and adult of the cat and dog flea. Pulex serraticeps. (Howard.)

of the floor; here the hatching larvæ feed upon such food as offers itself in such places, lint and shreds of clothing, scales of epidermis, and other organic or inorganic dust components. Human beings are also molested by the dog flea. The dog flea is provided with a row of stiff hairs projecting backward from each segment of the abdomen; while the human flea lacks these hairs. The whole 
development of the human flea requires about a month from the time the eggs are laid.

In tropical countries, the flea which infests the rat is very closely related to the human flea. This constitutes a serious menace to the health of our sea-coast communities. Rats are known to be distributors of the bubonic plague in their own country; and rats crossing the ocean from any of these countries, soon spread the infection among the rats where they land. San Francisco has had to fight this horror more than once. Undesirable people are not the only undesirable things we receive from foreign shores. 



\section{PART II.}

\section{ARTHROPODA EXCLUSIVE OF THE INSECTS.}

\section{CHAPTER XVIII.}

\section{NEAR RELATIVES OF INSECTS.}

\section{Myriapoda-Millipeds and Centipeds.}

These are air-breathing arthropods, having the head distinct from the thorax. The thorax and the abdomen form one continuous region with from six to two hundred segments in different representatives, each segment bearing at least one pair of legs. The millipeds and the centipeds constitute a class of the Arthropoda, some of which are harmless, some harmful, and some of them of real benefit to mankind.

\section{Millipeds.}

These myriapods have two pairs of legs on each segment of the body except the front three. The body in most of the representatives is cylindrical, the antennæ short and few-jointed. Millipeds may be found in damp places, under leaves, or when one turns over a stone or a board. Occasionally one sees on the sidewalk a reddish-brown, cylindrical "worm"; and if you touch it, it will curl up and lie perfectly motionless with the numerous legs on the inside of the curl, as if to persuade you that it is dead 
anyway and you might as well go on about your business. And if you pretend to do so, it will after some time uncurl and scurry away. (Fig. 95.) If it is smart enough to do this, you would better let it run-you would hardly have nerve enough to get away from your enemy that way; besides,

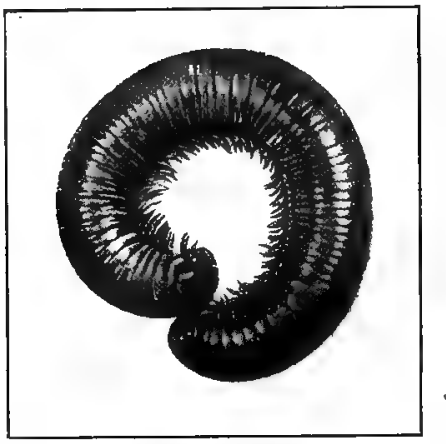

FIG. 95-A milliped, Spirobolus marginahus. Natural size. (Folsom.)

this milliped, like many others of its kind, feeds on decaying vegetable matter, which constitutes another reason why you should let it alone.

\section{Centipeds.}

These myriapods have but one pair of legs to each abdominal segment; the body is usually flattened, and the antennæ are long and many-jointed. (Fig. 96.) Centipeds are found in nearly all parts of the world. They abound in the United States, the species in the southern states being generally venomous, while the species native at the North are small and rarely inflict injury upon their human neighbors.

The centipeds are all predaceous, feeding upon insects, and also upon fruit and other plant food occasionally if 
they are southern centipeds. In the North, one may look for them under stones, logs, and bark. One species is often found running about over the house walls. It is a very swift runner, has very long legs, and only fifteen pairs of them. These legs drop off easily if the centiped is touched, and remain sensitive for some time. This centiped is sometimes called the cockroach tiger, and it has never been known to bite a human being. Its scientific name is Cermatia forceps.

It has remarkably long antennæ, longer than the body, and these seem to be extremely sensitive. They are carried forward when the animal is exploring things, and are waved gently up and down when the animal stops after having been disturbed. A Cermatia recently experimented upon, had a wet leaf thrust in its path so that the leaf touched the tip of one of its antennæ. It stopped abruptly, threw the antenna which had been touched in a

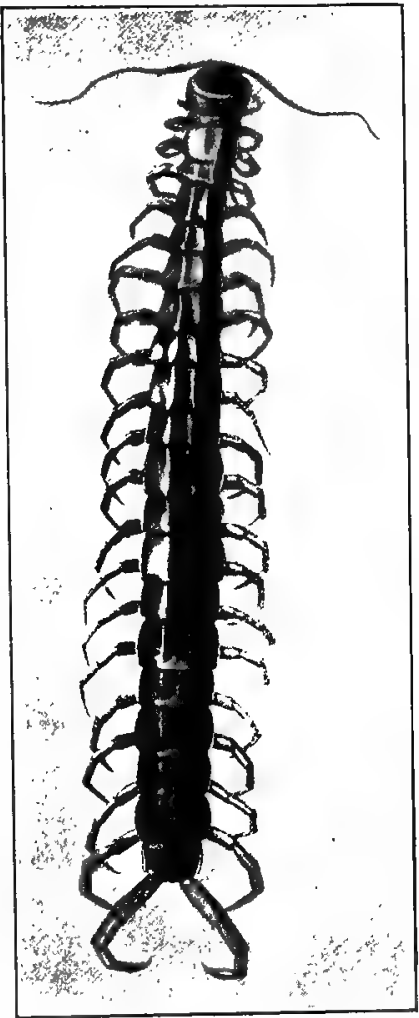

FIG. 96.-A centiped, Scolopendra heros. About two-thirds the maximum length. (Folsom.) long loop backward and upward, remaining in this position for some time with the antenna which had not been touched straight out in front of the head and quivering slightly. 


\section{Acarina-Mites and Ticks.}

These Arthropods have the abdomen unsegmented and fused with the thorax. They include the mites and the ticks. The majority of them are very small, though some of the ticks reach considerable size. All mites, except one family, hatch from eggs. In the case of this exceptional mite family, the eggs remain in the adult body after cell division in the egg begins, and until the segmentation of the young mite into head and abdomenothoracic regions with rudimentary legs. These young mites-or larvæ, properly speaking-are then discharged to begin their separate, individual existence.

Young mites usually have three pairs of legs, but develop a fourth pair while maturing. Some mites produce galls similar to those produced by the gallflies, but there is always an opening through which the young mite escapes. The itch mite infests the human tribe and burrows beneath the skin. With the exception of the mite which infests pear trees, all mites have four pairs of legs. The cattle tick is a true Acarina, but the sheep tick is a dipterous insect.

Mites are sometimes found on plants. The bestknown plant mite is the so-called red spider which so often injures house plants. In a dry summer it will sometimes attack fruit trees. It thrives only in a hot, dry atmosphere; hence the effective treatment of the pest is water and plenty of it, sprayed onto the under as well as the upper sides of the leaves. The mite seems to work mainly from the lower side, up through the juicy, green portion of the leaf, leaving the remaining upper part to wither and drop off. 


\section{Phalangina-Harvestmen or Daddy Longlegs.}

These Arthropods may be recognized by their very long legs, though some members of the class have much shorter legs, while resembling the typical harvestmen in the general body structure. The head and the thorax are fused to form the cephalo-thorax, with hardly perceptible segments or none at all. The harvestmen have two simple eyes, and instead of these being placed in the usual position as modified portions of the body wall, they are placed on long tubercles near the middle of the cephalo-thorax. The respiratory system opens on the ventral surface of the body, just where the cephalothorax and the abdomen join:

Although these "Grandfather Graybeards," as they" are sometimes called, are so easily caught, they have a means of protection in the ill-smelling fluid which they eject when they are disturbed. This defense is effective in the case of most birds. A bird has to be hard-pushed to eat so ill-smelling a thing. They are not strictly nocturnal in their habits, yet they avoid hunting in the broad daylight. Instead of being unfriendly to their own kind, as the true spiders are, several of these harvestmen may frequently be seen close-gathered in some half-lighted corner; and occasionally they seem to hunt in companies. Their prey consists of small insects, especially the green plant lice, which are such pests of garden plants. The Phalangina are really beneficial Arthropoda, and little children ought to be taught to protect them from harm.

\section{Solpugida-Jointed Spiders.}

These differ from all the other Arthropods, except the insects, in having the head separate from the thorax, and in having the thorax divided into the three familiar 
segments, pro-, meso-, and meta-thorax; in each of which characteristics they resemble the insects. In general appearance, they look very much like spiders, but because of these insect-like segments, they are called jointed spiders. The Solpugida of the western states are found in sandy regions, and are tawny and light brown in color. Their mandibles stand straight out in front of the head, and only the pincers of the mandibles are directed downward, which is the position of the mandibles in the true spiders.

The maxillary palpi are very long, and besides being used as guides to food selection, are also used as sensory organs to warn of danger, and as organs of locomotion. The front legs are without claws and are provided with sense hairs, that is, hairs capable of conveying sense impressions. So far as observation may be depended upon, these legs are often used as palpi.

With relation to the fact that the maxillary palpi and the front legs may be interchangeable in function, it may be remarked that on the basis of specialization of organs these arthropods must be of lower rank than are the arthropods in which there is no such shifting of function. Accurate bases for classifying living beings rest upon two supports, structural specialization and mode of reproduction; and on these two bases the jointed spiders would be classed lower than the true spiders. They are rare; they eat small insects, and have never been known to poison by their bite.

\section{Scorpions and False Scorpions.}

The true scorpions have the thorax unsegmented, the head fused with the thorax, and the abdomen differentiated into two portions - a pre-abdomen, broad and consisting 
of seven segments; and the post-abdomen, slender and tail-like, at the end of which is a poison sting.

The false scorpions have no such differentiation of the abdomen, and there is no sting at the anal end of the abdomen. False scorpions live under tree bark, in mosses, or they may occasionally be found between the leaves of some book that has lain unused for a long time. The true scorpions may be found in sandy regions, around old stone quarries, or other places not usually frequented by their human neighbors. (Fig. 97.)

Scorpions bring forth their young alive, and the young are carried about by the mother for some time. They attach themselves to the mother by their pincer-like mandibles. The adult scorpions are nocturnal, and feed upon spiders and insects, which they first sting to

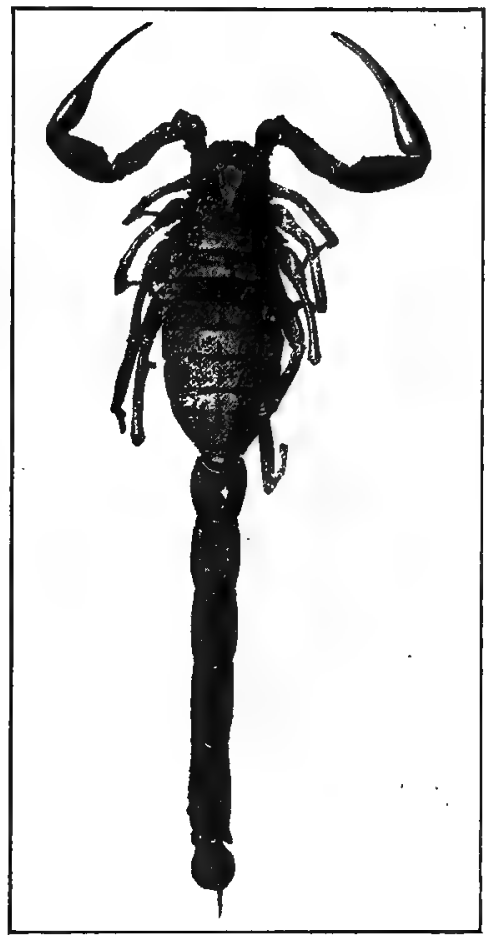

FIG. 97--A scorpion, Buthus. Natural size. (Folsom.) death.

The whip-tailed scorpion is found in the far Southwest, New Mexico and Arizona. This is the largest of the scorpions, measuring four or even five inches in length. The palpi are enormously enlarged into stout pincers 
which curve forward in front of the head, and make one's fingers ache even to look at them. The body is dark brown and rather heavily chitinized, even in the preabdomen. The post-abdomen is much slenderer than in the common scorpions. They destroy their prey by crushing it in their powerful palpi; hence it would seem that their sting is less a means of defense than is the sting of the common scorpions.

\section{Spiders.}

Spiders are not insects, though they are closely related to them. According to Comstock, the Arthropoda are to be divided into the Crustacea, the Myriapoda, the Hexapoda, and the Arachnida. The Crustacea include the familiar crayfish, or "crawdads," and the lobsters, the shrimps, and the crabs of our sea-coasts. The division also includes the familiar pill bugs, light gray, roundbacked creatures with a shell covering the dorsal surface of the body. They have numerous legs, and when they are frightened they curl up in a ball, shell outward, looking, as their name implies, like a shiny pill. They are found in damp places, under the bark of old logs, near wood piles, or under rotting boards. Their food seems to be decaying wood or other vegetable substances.

The Myriapoda have been seen to consist of the millipeds and the centipeds, The Hexapoda are the sixlegged Arthropoda or the insects; and the Arachnida, then, would include the scorpions, true and false, the jointed spiders, the harvestmen, mites and ticks, and the spiders. The spiders differ from the insects not only in the possession of an extra pair of legs, but also in the structure of the body. The head is fused with the thorax, making the cephalo-thorax, which is not segmented. The abdomen 
is also unsegmented, and is joined to the cephalo-thorax by a slender stalk. At the base of the abdomen are located the openings of the respiratory system; and at the apex of the abdomen are located the external organs of the spinning mechanism peculiar to spiders.

The appendages of the head are the labium, the maxillæ, the mandibles, and the palpi. The mandibles are two-jointed; and near the point of the second clawlike segment there is a small opening, the outlet of the poison gland. This poison kills or disables the insect victim; but its effect upon the human family differs in different cases, ranging from no effect whatever to serious inflammation in some cases. Possibly it may be with spider bites as we say of liability to a disease. We desire to believe, and it may be a tenable theory, that the perfectly healthy person is immune from all disease, the natural warders of the body, the white blood corpuscles, being in such a person present in such numbers as to be capable of disposing of all disease germs that may enter the system, with safety to the individual.

The walls of the cephalo-thorax are heavily chitinized. From this portion arise the four pairs of legs; and here must also be attached the many muscles used in the swift movements of the spider. The abdomen is soft and nonchitinized. The legs consist typically of seven segments -coxa, trochanter, femur, patella, tibia, tarsus, and metatarsus. The tarsus is usually composed of several segments, and is one-, two-, or three-clawed.

Spiders breathe as insects do, by means of tracheæ; but to the tracheæ are added two sack-like cavities, in which are numerous plates called pulmonary lamellæ. These sacks are really rudimentary lungs and have their openings on the front ventral surface of the abdomen; 
among the plates the air is kept in constant motion, and in the spaces between them the interchange of oxygen for carbonic acid gas takes place. The heart has branches along the sides through which the blood is sucked in, and finally the blood passes through these sack-like lungs. The tracheary system also has its separate openings, two of them farther back on the abdomen, near the anal end.

Unlike the insects, most spiders do not swallow their victim, but chew. the body and suck at it until it is little more than a mass of dry shreds. One may occasionally find in a spider's web the body remnant of some insect which has been so disposed of. Spiders are able to go for long periods of time without food; this is fortunate, for they must set their traps and wait for an insect foolish enough to fall into them. They are not gregarious in the least degree; each spider jealously guards its own food traps. Of course, in so doing, it simply obeys the necessary instinct of food-getting, and serves the law of selfpreservation. Even the male and the female spiders are bitter enemies for most of their lives. The male of any species may usually be known by the fact that he has longer legs and a slenderer abdomen-a fortunate provision that often saves him from being eaten by the fiercer and hungry female.

The sense of touch seems to be well developed. A spider, waiting for a bite, sits patiently in its web, if it is of the web-spinning sort. The wind may shake the web, a twig may fall through it, and the spider pays no attention. But let even a small insect hit one of the gossamer threads, and the alert spider is on its victim in an instant, either binding it with threads newly-spun, if it is large and threatens to tear the web and escape, or 
at once killing it in preparation for the feast. In locating the exact place of the insect in its web, the spider appears to use the sense of touch, telling from this sense which thread is vibrating, and thus running small risk of losing its victim.

Not all spiders spin webs to trap their prey. Some of them stalk their victims through the grass or in the usual lurking places of insects in barn or house. One of the light-colored crab spiders was recently observed to run down the cord of a window curtain, and pounce upon a luckless fly, sunning itself on the cord. These crab spiders seem to be less afraid of human beings than are most spiders. The author has several times offered one of them a fly and it accommodatingly stood still and let its human friends see it eat. When a second fly was offered, it seized the second and at the same time attempted to hold on to the first.

The trap-door spiders live in sandy or clayey soils, and instead of spinning webs they stalk their prey and then take it to their home to eat it at their leisure. Their home is one of the most perfect places of abode made by the Arthropoda. It consists of a burrow dug in the fine clay soil, and lined with a soft silken lining, the product of the spider's own industry. The opening to the burrow is closed by a lid, which fits tightly over the opening and is made of silken threads and soil, so disposed over and among them that the top of it looks exactly like, the ground about the nest or burrow. The lid is hung to the side of the burrow by a hinge also made of the silk threads. When disturbed on the hunt, instead of standing and showing fight, these spiders run to the mouth of their burrow, pop inside, turn partly around, and hold to their trap door with the two front claws while 
holding on to the walls of the burrow with the hind pairs of legs; and travelers say that one may more easily pull the lid off the hinge than to pull a spider loose while she is thus guarding her burrow.

The sense of sight seems to be but feebly developed in spiders, but they appear to be very sensitive to light as opposed to darkness. Spiders have no compound eyes, but have instead an unusual number of simple eyes, eight in most of the families. The object moving is pictured in quick succession by the numerous simple eyes, and the spider quickly takes the alarm and runs away. Whether spiders hear or smell is not known; at least there appears to be no unmistakable evidence of the fact.

The habit of spinning for trapping food would distinguish spiders from insects if there were no other distinguishing traits. Many of the lepidopterous insects spin cocoons when ready to pupate, and the cocoon of the silk-worm is made of gossamer-fine threads; other insects can spin some sort of a pupal case, and some worms will let themselves down out of harm's way by a spun thread. But as a means of gaining a livelihood, and as spinners of threads consisting of still finer strands drawn into one composite thread, the spiders are unique. The uses made of this spun silk are numerous. They use it in making linings for their nests, in making the sacks in which the eggs are to be stored, and in making traps of various shapes and sorts in which to catch their prey. Frequently the spider mends its web by tearing out the dirty or torn piece and, at the same time, spinning in new threads.

Webs are stretched in various places. The garden spider always places its web vertically. The house spider spins her web in the corner of the attic or the stable, or 
some other places where we think she ought not to be. A favorite habit of hers is to spin irregular webs in the angle from ceiling to side wall overnight. This has the entirely innocent purpose of trapping flying insects; but you object and rudely sweep them down next morning. Another spider places her web on the grass horizontally; another joins twigs of trees or bushes with a web placed either horizontally or vertically. During midsummer, in the early morning, these webs of the grass spiders may be seen glistening with dew.

Argyroneta aquatica spins a silken web on the stems of submerged water plants, fills it with air, and lives in it; the opening being below, the air cannot escape. This seems to solve the old riddle-

\section{"Under water, over water, \\ Yet never touching water.'}

The way in which she transports the air below water is interestingly recorded by Kingsley. The spider comes to the surface of the water, turns around, bringing the abdomen out of the water, and spreading the spinnerets apart so as to let the air in between them; then she closes the hind legs tightly over the spinnerets, and goes below with the drop of enclosed air glistening white against the water, backs to the opening of her nest, and spreading the spinnerets, lets go the air into the nest opening.

The flying spiders spin a float which, beginning as a tiny raft, soon becomes powerful enough to carry them away up into the air, if the breeze is stiff, on a merry sail in the late summer sunshine; or in the sunshiny autumn days, you may have felt the delicate ropes of this craft draw across your face, while the tiny aeronaut above was probably wondering on what reef his ship's anchor had caught. 
The spinning organs are numerous glands which lie in the abdomen, filling the larger part of the cavity; and the fluid matter in them leaves the spinning glands to be joined in larger, less watery groups of spinning material, and finally leaves the body by the spinnerets, six in number. Out of each of these spinnerets flows a drop of the semi-fluid material; and by some motion of the spider's body, the separate spinneret products are combined into one strong thread or cable. In spinning the web, the spider runs the supporting frame-work first, and as it spins the cross threads, if it is a round web weaver, it will glue each new thread every time it crosses the frame-work. If you are quiet and stand where your shadow does not fall on the place where the spider is working, you may see for yourself how she spins her web.

As to the development of spiders: each spider spins a tiny silken mat, upon which she lays her eggs; then she doubles up the corners of the mat and glues the ends securely about the clutch of eggs. Other spiders spin a large urn-shaped case with a small opening; the outside of the sack is formed of tough, compact silk, while the inside is lined with loose threads. The inside of most spider nests are similarly made, probably to keep the eggs from sticking together when they are first laid, as they are then wet and more or less sticky.

The rate of development varies. Some eggs laid in autumn develop slowly all winter; while others laid in early summer will hatch in a few weeks, often two. The hatching usually occupies a day or two. The tiny spiders are white, soft-bodied, without any hairs or spines, and with only small claws on the feet. Maturity is reached by frequent moultings. In a few days they begin to look more like spiders; the hairs begin to form, and the 
body becomes darker in color. In the case of spiders which develop slowly all winter, perhaps hatching prematurely, when the natural food does not offer, the young spiders are liable to eat each other. Indeed, in the summer time, if the brood hatching from one clutch is very large, the stronger ones in the sack hatching first eat the weaker; thus gradually thinning out the colony, and bringing about the survival of only the strongest spiders.

Before the second moult, the young spiders generally leave the cocoon or nest, and for a time live in a web which they spin together. This second moult occurs very soon after hatching and usually is not preceded by any eating on the part of the spiders; this early abstinence from food is not an anomalous condition. It is duplicated in the life of the young of many animals, such as chickens, ducks, and birds of many sorts, and even of some of the mammals. Subsequent moults bring the young spiders to adult form, size, and ferocity; and, because of this last fact, the separation of the brood into distinct places of habitation will have taken place before this period is reached.

Females of the family of running spiders keep their egg sacks with them attached to their spinnerets by the threads reaching from the spinnerets to the mouth of the egg sack. Another spider in the same family carries her egg sack about with her in her hunting expeditions, until the eggs begin to hatch; then she fastens the sack to some bush or other stem by a loose, irregular web of her own weaving. This web also serves the other valuable purpose of providing the young spiders with a chance meal of insects now and then. So far as known, this is the only instance among the spiders of care for the young beyond the egg stage. 


\section{CHAPTER XIX.}

\section{KEY TO FAMILIES OF SPIDERS. ADAPTED FROM EMERTON.}

Drassidæ.-Tube weavers; spin no webs, but make nests in form of flattened bag or tube; seek prey on ground among leaves. and grass. Body usually two or three times as long as wide; somewhat flattened on back. Legs about equal in length, two pairs forward and two pairs backward, velvety; hairs and spines short; feet with two claws with a brush of flat hairs; mandibles together as wide as head. Eyes eight, about equal in size, in two rows of about equal length and not far apart. Colors dull gray, brown, or black; few markings or none. A few species are brightly marked, and there are some slight differences in the different species in the arrangement of the eyes.

Dysderidæ.-Eyes six. Four breathing holes in the front of the abdomen. Appearance otherwise like Drassidæ.

Thomisidæ.-Crab spiders; flat, short-bodied, much 'wider in the abdomen. Travel sidewise, look like crabs. First and second legs often much longer than third and fourth; all extend sidewise from the body. Feet with two claws and thick brush. Body smooth or covered with very fine, soft hair; coarser hairs sometimes scattered over back areas. Eyes small, in two curved rows, upper row the longer. Mandibles small, narrowed at the end.

Attidæ.--Jumping spiders; live in open places among 
low plants, occasionally seen running across sidewalks; quick in movements. Most of them brightly colored, colors change when spider is wet. Body short and stout; cephalo-thorax large, wide in front. Eyes eight, in three rows, middle two of first much the largest; two eyes of second row very small; two eyes of third row far back on head. Length of legs varies with different species, often front pair longest; feet with two claws and thick brush; walk backward or sidewise. Make no webs, but a tube or bag to hibernate in.

Lycosidæ.-Running Spiders; our commonest spiders; live near ground; do not hide. Colors black and white or colors of ground, stones, or leaves, sometimes uniformly arranged, sometimes in patterns. Fourth pair of legs longest; spines on legs long, stand out in running; feet with three claws, under claw small and covered by hairs. Eyes in three rows, four eyes in the lowest row, two big eyes in the middle row, and two small eyes farther back and wider apart for the third row. Body long in most species; head high; abdomen about the width of the cephalo-thorax, and as thick as wide.

Agalenidæ.-Larger ones make flat webs common on grass, horizontally, and in corners of barns and cellars. Head large and marked off from thorax by shallow grooves, contracted behind eyes. Mandibles large, swollen at base (female). Eyes like Drassidæ. Upper spinnerets longest. Feet with three claws and a brush. Males have longer legs, smaller abdomen. Palpi large and complicated.

Therididæ.-Loose irregular webs, no flat sheet, but a loose tent in which the spider stands; in upper roomcorners, on fences, between rocks, on leaves and branches of low trees. Body small, soft, light-colored; abdomen 
large and round. Legs slender, no spines. Eyes about the same size, in two rows close together, often touching. Mandibles weak, without teeth. Maxillæ pointed and turned inward. Most of them live in webs, hang back downward.

Linyphiadæ.--Roof weavers; body elongated. Legs stout with many spines. Mandibles large, strong, with teeth around claws; maxillæ not inclined toward labium. Live in shady woods, under leaves, in caves and cellars; colors plain and dull. Web usually a large flat sheet supported by threads, and under this the spider lives.

Epeiridæ.-Round web weavers; hang in web or nest, back or head downward. Cephalo-thorax short in most of the species, low and wide in front. Eyes eight, side pairs close together and farther from middle eyes than middle eyes are from each other-all located near front edge of head. Mandibles large; maxillæ short and not pointed nor turned inward. Legs long and stout in most species. Abdomen, in some species, rounded and curiously humped or angled. Colors often bright, and arranged on abdomen in triangular or leaf patterns. Some species show deceptive coloration for concealment among the plants where they live.

Cribellata.-Six spinnerets and a cribellum, a flat, wide spinning organ in front of the spinnerets; calamistrum on hind legs, that is, a row of hairs to draw out the band of silk from spinnerets and cribellum. Feet with three claws. 


\section{PART III. BIRDS.}

\section{CHAPTER XX.}

\section{GENERAL DIRECTIONS FOR FIELD WORK ON BIRDS.}

The best general equipment for classes within the scope of this work on birds, is a good field glass, which ought to be the property of the school, a camera or a kodak, and some good guide to the identification of birds. If Reed's excellent little book, "Bird Guide," is the one used, each member of the class ought to have his own copy. If Chapman's "Color Key to North American Birds" is chosen, there might be fewer books needed.* But so far as experience goes, it would seem that the condition where each member of the class has his own little manual secures the best results.

The field glass is indispensable for studying birds in the open. It brings the bird within close enough range for its identification. Birds fly so rapidly and are so easily disturbed, or they perch so far away, that one cannot get near enough for a "good look."

A camera or a kodak, it can be a Brownie kodak owned

* Information concerning the two books mentioned may be had of Chas. K. Reed, 238 Main Street, Worcester, Massachusetts. This gentleman also furnishes a field glass for bird study. 
by the school, or it can be the property of some member of the class, is an adjunct of the first order in studying birds. The memory does not always serve one as to how a given bird looked, or where it was found, what it was doing, what kind of a nest it built, whether it was found social or solitary, and whether the birds of the pair looked alike. All these things the kodak will record faithfully, and it will furnish them on demand for future reference.

Pages 260 and $26 \mathrm{I}$ afford suggestions for the different areas which may be studied. The locality where the study is being undertaken, and the environing neighborhood must also furnish many other suggestions. In large cities, some of the shy passerine birds and picarian birds will occasionally nest upon the roofs of tall buildings. About factories, in spite of the noise and smoke and the presence of human beings, there may occasionally be found members of the sparrow tribe. In the communities less cosmopolitan, the opportunities are more numerous for getting acquainted with more sorts of birds than in the city. But in the country town or the village, one finds the ideal conditions, conditions which are usually well-nigh perfection for the study of the feathered tribe. Especially is this true if the outskirts of the village merge into the woodland, or lose themselves in some river or marsh or stream with an undergrowth of bushes and tree thickets. Both city and country conditions may be made to yield their secrets of bird life, if one has eye and ear alert to perceive. When you hear a bird-call, then is your time to seek a glimpse of the bird. When about one's regular duties, it frequently happens that from some unexpected source there will come just the item of information which you may have desired for days. In this, as in all things else, what one heartily desires, that will one attain unto. 
The object in bird study, as it was in the study of many of the insects, is the knowledge of the birds, not the killing and the mounting, nor yet the killing and the eating-and surely not the killing for a sharpshooter's medal, or some aim more idle still. A record of the facts gleaned from a study of birds, if faithfully and neatly kept, may turn out to be valuable at some future time in ways which may be entirely unforeseen at the beginning. This is the way in which all the men who have since become useful in the great world of science have begun their life work. And they are proofs that it always pays to do a thing faithfully and well.

As suggested in the pages mentioned, there are certain times of the year during which bird study is especially interesting and profitable, and these are the nesting season and the season of migration. There are many new facts yet to be discovered about these two phases of the bird's existence; besides the many problems concerning individual birds and their neighbors, and the bird's ways of meeting the growing needs of its environment.

If the class is near enough to some museum of natural history, it will be a rare privilege to study the birds at close range, where they will all sit still long enough to be studied completely. Other ways of doing will suggest themselves to the earnest teacher who is alive to the duties and privileges of the situation. Special aptitude for the subject is not an indispensable requisite, although it makes things easier, but there are needed such qualities as these: a clear aim; an enthusiasm which is warranted not to flag; and a genius for patience. These given, the reward is sure. 


\section{CHAPTER XXI.}

\section{INTRODUCTION TO BIRDS.}

Birds belong to the class Aves. This word is the plural of the Latin noun, avis, meaning a bird. Birds constitute a much smaller class of animals than do the insects. The Arthropoda, the branch of the animal kingdom to which the insects belong, is the most numerous of all the groups, comprising more known sorts or species of animals than do all the other branches put together. Williston places the number of flies alone, known at the present time at eighty thousand. And every year witnesses discoveries of Arthropoda hitherto unknown, as the study of familiar regions becomes more intensive, or as new earth and ocean regions are explored for the first time. Just now, in these days, are appearing accounts of the explorations of several traveler naturalists in South American, West Indian, and East Indian lands, men who are doing much as did men in the days of Linnæus, when they traveled into foreign lands for the sake of seeing the wonderful sights of Nature in the way of rock, plant, or strange animal. But in these latter days, our travelers have to guide them all the great body of truth which it has been man's privilege, under God, to discover, from the days of Linnæus down to the present time.

Life is the most wonderful of all the facts of creation, and only life can understand life and discover its meaning. Its full meaning is always a little beyond the compre- 
hension, and yet there is always something in the nature of the highest of created beings, man, that urges him ever forward toward a fuller understanding of life, its powers and individuality of action, as manifested in plant or worm, insect, bird, or man.

At the head of the animal half of the life kingdom is man, and below him, other numerous, and some of them scarcely less wonderful mammals, as the horse, the dog, the elephant, and the fox.

As to the place of birds in the animal kingdom, they stand just. below mammals and just above reptiles; and more closely allied to reptiles than they are to mammals in points of structure, but more closely approaching man in sense development. Taken as a class, the Aves are more clearly defined than any other group of the higher animals. The birds most unlike each other are still more closely allied than are the varying life forms among the fishes, the reptiles, or the mammals.

There is good evidence that birds had reptilian relatives in the good old Jurassic days, and to one of them was given the not unmusical name of Archæopteryx, a name which means ancient bird. Two specimens of this bird have been found, and both of them in the slates of Solenhofen in Bavaria. One of them is now preserved in the British museum, and the other in the museum of Berlin. It had the feet, the limb bones, and the beak of a bird; but the beak was set with strong teeth. The tail was as long as the rest of the backbone put together; and the vertebral bones extended on down into the tail, and from these the feathers came off in pairs, one feather on each side. (Fig. 98.)

The Archæopteryx was about the size of a crow, and probably climbed trees by means of the hook at the 
apex of the first wing bone. In support of the theory of life continuity from simple to complex, it is to be noted that a living South American bird, the hoatzin, while young, has similar hooks at the apex of its first wing bone, and it climbs trees by means of feet, bill, and these claws.

Birds have also been discovered in the Cretaceous strata of Kansas. In 1870, Professor Marsh, of Harvard, dug up a specimen of a bird in western Kansas, near the

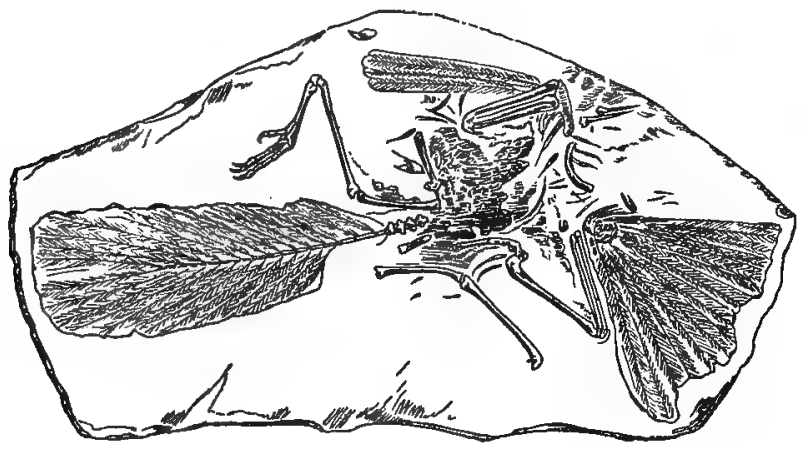

FIG. 98.-Archaopteryx lithographica, an early Reptilian Bird. (Galloway, from Claus.)

Smoky Hill river. It was named the Hesperornis, and was evidently a water bird, as it had no wings; but its legs, feet, and tail were remarkably adapted for swimming and diving. Its tail consisted of twelve vertebræ, the hind ones flattened, much as in a beaver's tail. Several other birds have been found in western Kansas and the bones of about fifty different specimens of these birds are in possession of Yale University.

All the western Cretaceous birds have been found in the soil of western Kansas, except where the same formation in Texas furnished a few; while the eastern Cretaceous birds come from the Green-sand of New 
Jersey; and these latter represent a later period in the earth's history. The Hesperornis measured about six feet from bill tip to toe end, and must have stood, according to Marsh's restoration, about three feet high. It seems to have been a huge diving bird with the general build of a loon. The Ichthyornis, another find in the same formation, was a much smaller bird about the size of a pigeon, and had more of the characteristics of the birds of nowadays. The earliest known bird of the passerine type belonging to the United States, was found in the Florissant Beds of Colorado, those rock beds that have yielded so many specimens of fossil insects also. This bird shows relationships with the immense modern family of the Fringillidæ or finches, sparrows as they are more commonly called. To-day, birds are more widely distributed than are any other animals.

The relationships of birds to man present three phases of study: the scientific, the economic, and the æsthetic. The embryologist, the systematic classifier of animals, the comparative physiologist, and the psychologist, all find abundant material for study among the birds. Among the students of birds may be mentioned Audubon, Coues, Ridgway, Jordan, Goss, Chapman, and a host of lesser students of birds. The labors of these eminent men are of use to the amateur in enabling him to become sufficiently acquainted with birds in their resemblances and differences, to know them in their groups and families, to understand much of their anatomy and physiology, their peculiarities of inter-dependence and relationship among themselves, and the similarities of their sense powers, activities, and behavior to man.

The economic value of birds to man rests upon the service they render to him in preventing the increase of 
injurious insects and burrowing rodents, and in eating the seeds of harmful plants, or devouring refuse which, if left, would be a menace to the health of the community. Many of the birds which are known to be seed-eaters are not, for this reason, to be set down as harmful birds. The seeds eaten may be seeds of troublesome or harmful plants. A great many of the birds that stay north during the winter, or come south at that time, devour large quantities of weed seeds-a fact not to be disregarded in the economy of our seed-planting, plowing, and harvesting.

Among our specially useful birds are the woodpeckers, both downy and hairy, yellow-billed and black-billed cuckoos, bluebirds, robins, brown thrashers, catbirds, grosbeaks, red-winged blackbirds, sparrow hawks, quails, prairie chickens', marsh hawks, red-tailed hawks, barn owls, swifts and swallows, the large family of sparrows, the warblers, and the vireos. Others might be mentioned as valuable to man, but these whose names are here given do such great service as to deserve special mention. The service rendered is simply obeying the instincts of foodgetting and of caring for their young; but by a wise provision of the Creator, the two necessities named lie heaviest upon these birds during our season of crop-growing and harvesting. Moreover, in order to do themselves this good and us this service, most of these birds just named journey on their tiny wings a thousand milessome of them much more, some less - going far south when our summer is over, and coming back when our spring returns. And yet many people see no more in this than a casual happening, something to be taken for granted, instead of a great lesson of the Creator, taught anew every spring in the flutter of hundreds of wings and the melody 
of bird songs, as our summer friends come flocking back to the meadows, fields, gardens, and orchards that need them so badly.

The insectivorous birds, in their search for daily food, explore different regions. The swifts and the swallows have the air for their hunting grounds, the swallows often hunting flies and gnats far into the twilight. Nighthawks and whip-poor-wills take up the hunt after nightfall. The flycatchers, in their dun-colored coats, will sit in the shadows of tree or bush, ready to dart out at a passing insect, or they have been known to locate a gnat swarm and sit with open mouth in the path of the flying swarm, filling their crops to overflowing. Warblers explore the circumference of herb, shrub, or tree, picking off leaf-eating insects. The vireos do police duty on the underside of leaves and in out-of-the-way corners. The woodpeckers and the brown creepers take up the chase on the tree trunks and the larger limbs, exploring every inch for some flat-headed or round-headed borer, for ants, or insect eggs. A woodpecker can get himself a fairly good meal out of a telegraph pole, but he will do better service on an elm tree. The orioles, the cuckoos, and the blue jays delight to hunt for caterpillars, hairy and smooth, in and out among the foliage and fruit, where worms may be found eating leaves or curled up comfortably in some blossom. Such sparrows as are winter residents live off weed seeds principally, while the summer residents of the tribe are for the most part ground feeders, and find a rich harvest in insects and seeds near the ground. Aquatic birds help the dragon flies eat the mosquito larvæ; or occasionally there is found a bird shrewd enough and quick enough to turn the tables and eat the dragon flies. Along our sea-coasts, aquatic birds do great service as 
scavengers. This is a service little appreciated. Along bay, lake, pond, river, or stream, flies, moths, beetles, and other insects frequently fall into the water and are drowned, and their bodies lodge in the shallows or are swept down stream. One hardly suspects this fact till on some lazy summer afternoon, he lies quiet and motionless in the shadows and sees over and over again about him the enactment of this tiny tragedy, of insect fall and quick pursuit by the bird.

Hawks and owls as a group, with the few exceptions of Cooper's Hawk, the Sharp-shinned, and the Goshawk, are of large benefit to farmers in getting rid of the small rodents so destructive to growing crops. No one knows this so well as the cattlemen on the western plains, who regard the hawks as valuable allies. It is difficult to overthrow an age-old belief, and to convince people without repeated and strongly impressed proof; but every student of birds, and everyone interested in crops and their dependence upon different birds in different parts of the world, ought to do his utmost to correct the prejudice against the family of hawks. The reprobates of the tribe have just been mentioned; but there are plenty of beneficial hawks whose service should be a matter of gratitude, on the part of farmers especially.

Analysis of numerous stomachs of hawks, the most conclusive way of determining a bird's habitual diet, reveals the facts that squash bugs, grasshoppers, and large caterpillars are freely eaten, while the marsh hawk is a valuable destroyer of field mice and ground squirrels. The sparrow hawk is a valuable ally in getting rid of grasshoppers; the adult red-tails eat largely insects and mice; and the young of the hawk tribes are more exclusively insectivorous than are the adults. 
The terrestrial scavengers are the vultures, the ravens, and the buzzards; while along our shores are the scavenger cormorants, herons, and gulls, though gulls usually work farther out to sea than do the other birds mentioned.

Birds are the best friends the farmer has, not excepting our Secretaries of Agriculture, state and national. Even the corn-eating crow that we hear so much about in the spring has been eating mice and grubs and scraps through the winter; while in the grasshopper season he probably eats more grasshoppers than corn grains, day for day; and grasshoppers increase much faster than crows. It is not to be denied that crows do some damage to sprouting grain; but there is hardly any animal that is at all times beneficial. How about ourselves, for instance?

In a recent government report, a yellow-billed cuckoo, killed at six in the morning, had in its crop the partiallydigested remains of forty-three tent caterpillars! How many more it would have eaten before nightfall is a question. Birds digest their food very rapidly, so that it is difficult to make estimates covering much time, and the cuckoo belongs well up in the scale of bird life, where all the vital processes are rapid.

Besides furnishing "bread and butter" for scores of birds, insects are eaten by many of the other vertebrates. Lizards, toads, frogs, and prairie squirrels catch insects as long as the insects are with us; that is, until the approach of winter leads to the disappearance of their natural food, when the conditions lead up to the hibernation of many of these animals. The mole, which has a reputation for being such a pest, is only trying to get the white grubs and the caterpillars that have dug under the ground surface to winter over. Of course, as the 
mole tunnels around among the grass roots in search of his breakfast, he does not take the trouble to go back and cover up the grass patch where he found a fat grub. The juicy meal only fills him with a craving for more, and on he goes. Field mice and skunks eat grasshoppers. Fresh-water fishes are insectivorous to nearly fifty per cent of their diet. Hence, and this is the valuable point, these insectivorous animals cannot be destroyed by an agency outside their own domain without disturbing the nice balance of nature. Only in regions destitute of man's presence is this balance most nearly preserved. Man is the largest disturbing force.

The study of birds should not be restricted to any one season, nor to one locality; but should cover a year at the very shortest for a locality and its surrounding country. For instance, if you are in the country for your special field, your study should cover also the nearby town. The different zones of life ought to be investigated; the ground birds, the tree-top birds, the day and the night fliers, the woodland birds and the birds of the open, the morning and the evening birds, the shy birds and the birds that like the society of their human neighbors.

Their food habits should also be a matter of study. You can be reasonably sure that when a bird is astir he is doing one of three things: hunting for food, singing, or looking after the home, either the prospective home, or the home in possession. In addition, birds have individual traits; as pugilism, for the pure pleasure of downing an opponent; poaching, running another bird off his feeding-grounds because he is bigger and can do it; blustering braggadocio, which, by the way, is often able to gain its ends; and sly cunning, which quietly gets ahead of the other fellow and leaves him wondering 
what has happened. These are a few more of the ways in which birds bear out the biologist's assumption that they are closely related to man. White-rumped shrikes, blue jays, house wrens, and English sparrows will reveal these traits; and if you will study the birds in your own neighborhood, you may be able to discover additional traits.

Be continually on the alert. If you hear a bird call, catch a glimpse of the bird; it may be that you will have to run; or, if it is an insectivorous bird or a seed-eater, you may have to steal around the base of the tree several times, tracing the bird's fleeting shadow as it creeps in and out among the leafy twigs. It is making as little noise as possible, so that it may not frighten the worm out of sight, and you must do the same with respect to the bird: 


\section{CHAPTER XXII.}

\section{PHYSICAL FEATURES OF BIRDS.}

As to the physical features of a typical bird, we may consider the uses of the bill, the feet, the tail, and the meaning of the coloration of birds. We are to understand that the biologist does not think that things just happen, and have no meaning nor use in the great scheme of life. No life trait appears without the preceding stimulus to that form of activity; hence under the operation of this law all those features characteristic of an individual are seen to be fraught with meaning to the individual in the ease or success with which he "gets along in the world."
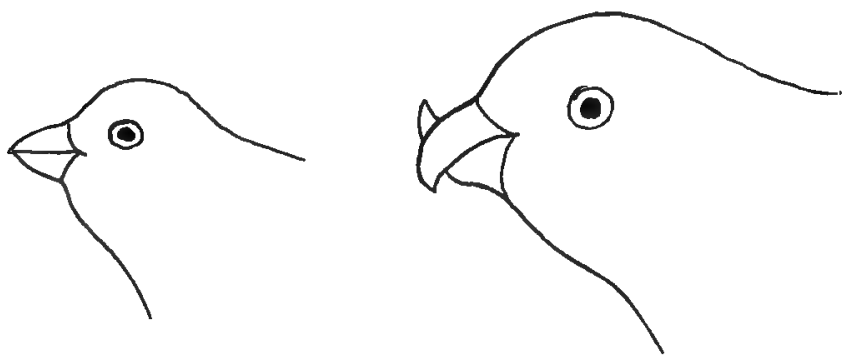

FIG. 99--Conirostral bill of a canary. FIG. Ioo.-Falcate bill of cross-bill.

\section{The Bill.}

The chief office of the bill is to take the place of the hand, which the bird lacks. It really belongs to a biped which is without arms or hands, and so must make the bill do much of the work of both these members. It is the organ of prehension, of defense, and is of use in making 
the toilet. In the nesting season, it is always more brightly colored than at any other season of the year; and some birds have it adorned in some way, with an outgrowth of feathers, perhaps, near it and accentuating its beauty at the nuptial season.

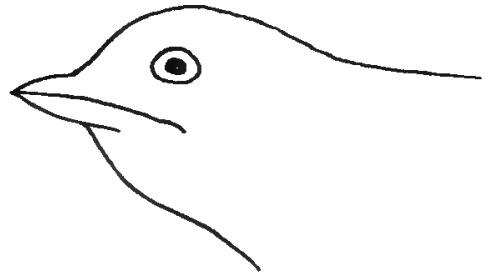

FIG. Ior.-Fissirostral bill of a swallow.

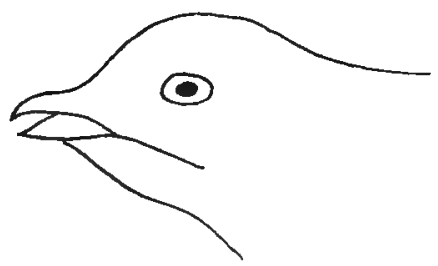

FrG. 102.-Fissirostral bill of a chimney-swift.

The shape of the bill is indicative of the food habits of the tribe of birds. The long, thin, pointed bill indicates the insect and worm eater; the short, stout conical bill belongs to the seed. eaters; the stout, hooked bill indicates the flesh eater, which tears its victim, fish, mouse, rabbit, or decaying carcass; the American crossbill cuts out the pine seeds from the cones, more effect-

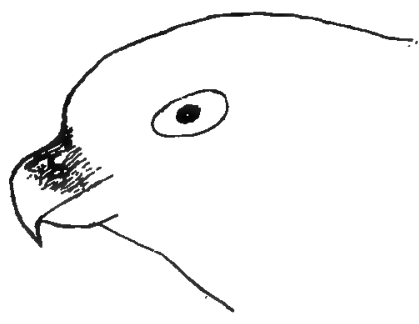
ively than it could be done with a pair of scissors.

A few birds, as the owls, snap the mandibles together if they are frightened or angry. All birds use the bill as a toilet accessory, while performing the curious duty 
known as preening their feathers after a water-bath. This they do by pressing out a drop of oil from the oil gland at the base of the tail, and rubbing it smoothly over the feathers while drawing the feathers through the bill. Aquatic birds, such as the domestic and wild ducks, make special use of the advantages derived from this process; as the oil renders the feathers less readily wet by water. Grebes, which can remain long under water in the act of diving and swimming, come out dry and glistening, ready for another plunge, because of their oily plumage.

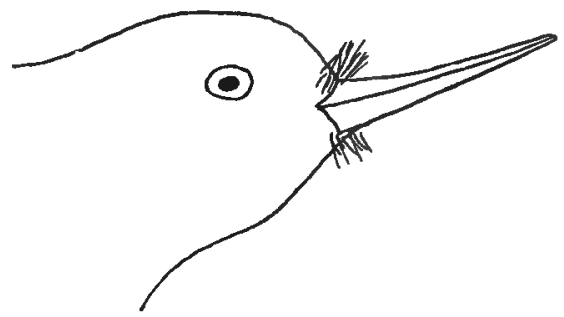

FIG. I04-Tenuirostral bill of a nuthatch.

Parrots use the bill in climbing. Some birds use the bill as a weapon. But as an organ for securing food, the bill has shapes as various as the food habits of the genera of birds. It may have the form of a lever in one tribe of birds, a pair of forceps, a hammer, a sieve, an awl, a hook, or a knife in others.

\section{The Feet.}

Aquatic birds have lobed or webbed feet; or if the bird lives in swampy places or wet grass land, the toes are long and strong. In the Mexican and South American jacanas, the toes are enormously lengthened, a provision 
which makes it possible for the bird to walk over the water surfaces in its native haunts by stepping on the broad leaves of the water plants. Our own shore and swamp

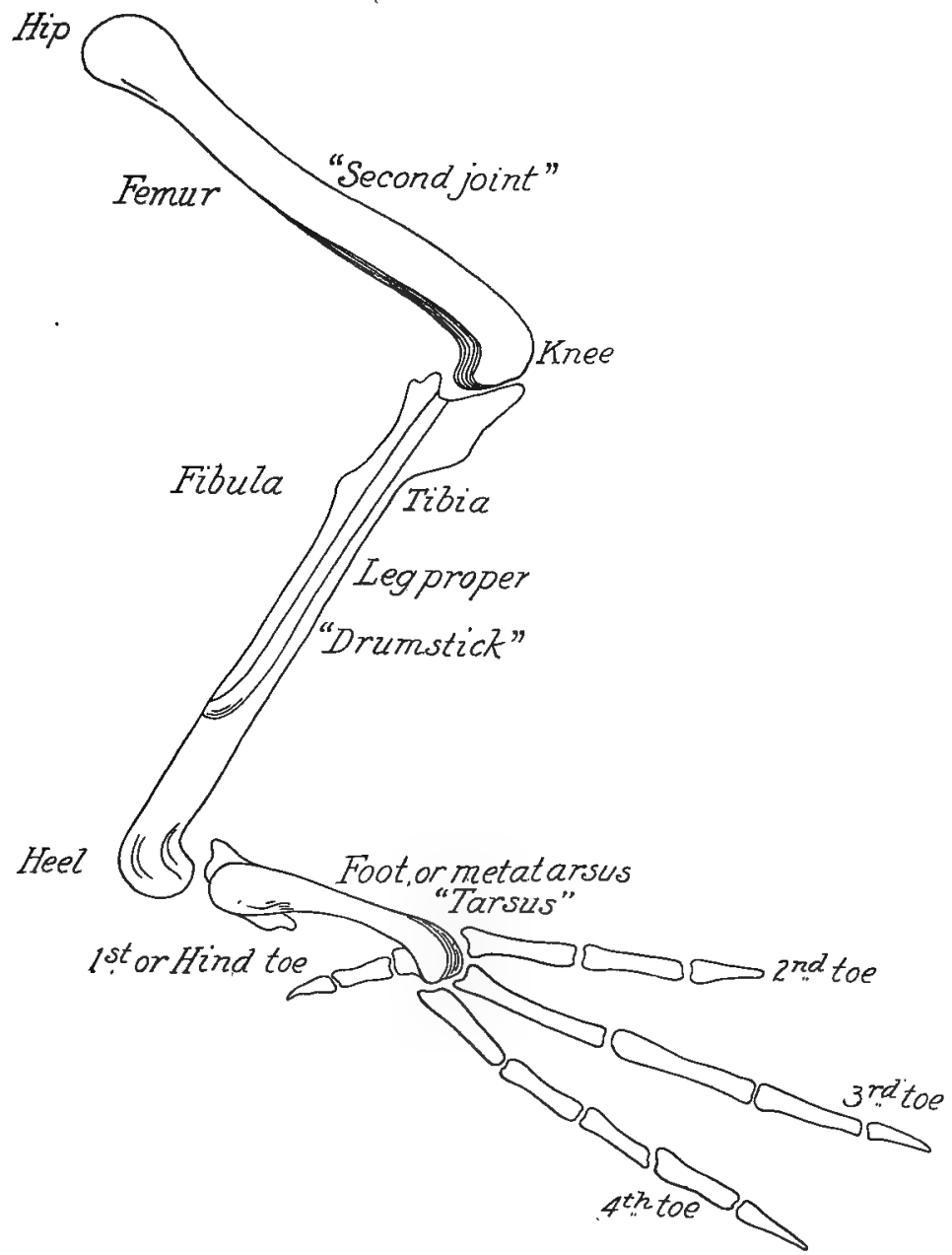

FIs. I05.-Hind limls, or leg and foot, of a bird. (After Coues.) 
inhabiting birds have these long toes also. The shortlegged, slim-bodied rails have toes all out of proportion to the length of leg and body; but their efficiency is such that the bird easily finds its food or eludes its enemy in its marsh home.

Parrots use their feet as a hand, holding the food in them while tearing it in pieces for devouring. Hawks often carry nesting material in their claws; and birds of prey as a class hold their prey in the talons while tearing it into morsels. Ostriches have especially strong feet, besides being able to kick. The grouse have naked feet in the summer; but in winter, the feet are thickly feathered to the toes.

In the matter of getting about on the ground and in trees, birds use their feet variously. For instance: do you know whether a blackbird, when it is on the ground, puts one foot before the other, as we do in walking; or does it hop, using both feet alike? How does the blackbird get about among the tree leaves? Do robins, bluebirds, domestic pigeons and chickens, quails, hawks, and eagles, walk or hop? How do the woodpecker and the brown creeper use their feet when going about over the tree trunk? The flickers are often seen on the ground looking for ants; how do they use their feet at this time? Does the domestic hen stand on one foot while she scratches with the other? Does the parrot use both feet together, or alternately? If you are fortunate enough to discover a bird at work building its nest, try to discover whether it uses both bill and feet, or only one of these members, and which one?

How do domestic ducks use their feet in swimming, alternately or simultaneously? Do they dive? If so, for what purpose? Do they eat afloat or ashore? 


\section{The Tail.}

The shape of the tail is in accord with the bird's habits of flight and food-getting. Its main office is to act as a rudder in flying, and as a balancer in alighting from flight. The inter-action of the muscles of the tarsus and the tibia with those of the toes is such that the perchers among the birds are safe on the trees, even when sound asleep. The natural bend of the bird's foot comes between the heel and the toes. Now, with some of the muscles attached to both tarsi and toes, and playing around the bend of the foot, the toes are firmly locked around the twig on which the bird may be sitting; and the bird must make a real effort to let go rather than to hold on. This coordination of muscular effort is perfected only in the fully-developed bird; hence the young bird, or the bird with its tail only partially grown, or the old bird deprived of its tail, are both awkward in flight and unsteady in alighting.

Most birds walk on their toes with the heels considerably elevated above the surface over which they are walking. If you would see the force of this, try walking on your toes with your heels elevated. The birds which do walk on their heels, the cormorants and the grebes, are exceedingly awkward and unskillful on the land.

Long-tailed birds fly with greatest ease, and can even turn sharp corners with marvelous success. A robin, digging for a rapidly descending angleworm, uses his tail as a sort of fulcrum for the necessary leverage in raising the unlucky worm. All the tree-creeping birds use the tail as a prop or brace. The motmot gesticulates with its tail, as do also the angry wren, the robin when he has his fighting blood up, the catbird when you go near his nest, or the amatory blackbird when he is doing his 
best to appear well before some maiden blackbird. In some species of birds, the tail is more expressive of the emotions of the bird than is any other organ of the bird. The stiff feathers of the tail are called rectrices.

In birds, as in all classes of animals, there are facts expressing gradations of development. We speak of the birds of highest nervous development as the highest family of birds. Nor is this fact without its accompanying facts of classification. These are also the birds in which we find the altruistic instincts best developed, in which we find fatherhood no longer deprived of its share in the interests of the offspring. Again, in the highest class of birds, we touch most closely the life of the human family, where, oftentimes, the bird is willing, if we will let it, to work in happy partnership with man, both reaping legitimate gain from the same region. In this class of birds, we find some that are able to pit their shrewdness against the shrewdness of man, and in eight times out of ten come out ahead; for example, the English sparrow.

\section{The Wing.}

The wing is the organ of flight par excellence. It has furnished to the human race the inspiration to "go and do likewise" from the days of Darius Green to the Wrights and the host of other present-day aviators. The albatross and the gulls are almost tireless on the wing. It is true for the bird in general that it seems to be in more stable equilibrium when off its feet, either in the air or the water, than while it is perching or walking, probably due to the fact that the base within which the center of equilibrium then lies is so broad, the wings being set quite a good deal forward of the feet. The quadrupeds below birds go on all fours, with the head little raised above 
the horizontal body level. In the bird, we have an upright quadruped; or a biped with the front limbs used as wings, and the head considerably above the rest of the parts of the body. This narrows the base within which the center of equilibrium falls while the bird stands upright; but when the bird spreads its wings it bends forward, and thus widens its base and places itself in more stable equilibrium. Yet, skill in flight has its degrees of excellence of development in the different sorts of birds. The birds just mentioned are the most notable fliers among the aquatic birds. Among the land birds of North America, the buzzards and certain of the hawks come the nearest to being tireless on the wing. The most familiar feature of the landscape, in some parts of the continent, is the vulture, or buzzard, as he and his comrades soar above the land expanse beneath, no part of it hidden from their observing eyes, searching for a carcass, soaring till they find it, apparently alighting only when feeding. The hen hawk, the familiar red tail, was watched by one observer from seven in the morning till four in the afternoon, during which time it kept aloft in the air.

The skeleton of the bird's wing has much the same construction as our arm; insomuch so that we call the large bone articulating with the shoulder the humerus; the two smaller bones below it and articulating partly with each other, the radius and the ulna; while the still smaller bones or series of bones on beyond the radius and the ulna are called the fingers, the one just at the turn of the wing corresponding to our thumb, the middle and longest finger corresponding to the middle or main extension of our hand.

As organs of flight, the wings are provided with 
stiff quills or primaries, the one lying lowest and undermost being called the first primary. These are reinforced by the secondaries, lying above the primaries, and generally of rounder and softer outline. The barbs of the primaries are unequally developed on the two sides of the central shaft; the barbs on one side being set at a higher angle and often being of shorter length than the barbs

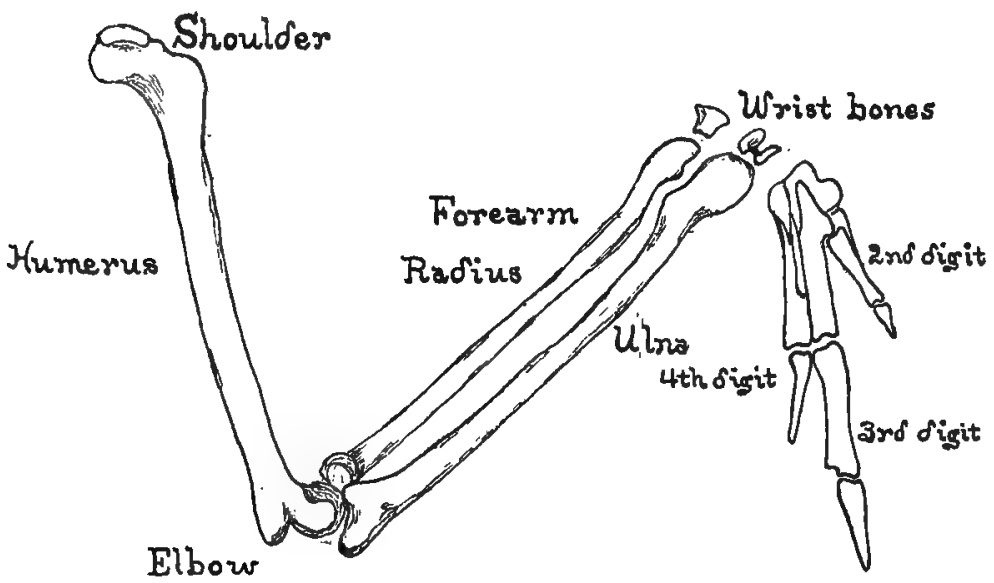

FIG. 106.-Front limb, or wing, of a bird. (After Coues.)

on the other side of the shaft. In the secondaries, the barbs grow more nearly symmetrically. Complex muscles connect with the epidermal sockets from which these feathers grow; so that the bird, in flight, spreads the barbs apart and turns them so as to "feather its oars" in the aerial ocean which it inhabits.

The upper arm is not free from the forearm, but a fold of skin crosses the space between them and a strong muscle supports this fold of skin between shoulder and wrist, diminishing or increasing their approach to each 
other as the bird beats the air with its wings, or keeping taut and tense as the bird soars, apparently a motionless speck in the blue above our heads. The number of primaries is usually constant, being typically ten; but in the highest birds the first primary suffers various degrees of reduction, ranging through short and spurious to obsolete, in which last case it has disappeared, and but nine primaries remain.

Like the hand, the wing of a bird is capable of expressing emotion. The challenge to battle, the attitude of defense, the tenderness of the nest-mate, the helpless need of the tiny nestling, all are expressed by various movements of the wings. As to the feathers covering it, the wing is in many birds one of the most highly varied areas of the plumage, vying with the head and the tail in the brilliancy of its coloring.

The wing may also be used as a musical instrument; though in this case it is instrumental music, of course. The woodcock whistles chiefly through the use of its curiously marrowed outer three primaries.

\section{Coloration}

The plumage changes with the season, with the nesting period, with the age of the birds, with the climate, and with a change of food. It is a well-understood fact that birds are lighter in plumage in arid regions and darker in humid regions. For instance, one of our sparrows, the common song sparrow, having a range from Arizona to Alaska, is a pale, sandy-colored bird in Arizona and dark sooty-brown in Alaska. Between these extremes are to be found nine intergrading species, according to Coues. Some animals are more affected by climate than are others, and this is a rather extreme example. 
It is a fact that will probably hold good throughout the animal kingdom that organisms of high nervous organization are more open to variation in any of its modes of approach. These climatically produced subspecies are to be regarded as variations upon a single species; but if the climatic barriers were destroyed, or if some climatic revolution were to cut off the intervening species completely from each other, then, in the first supposed case, the subspecies would gradually disappear, all the individuals tending toward one form, expressing the fact that climate had the same measure of effect upon all; or, in the second supposed case, the subspecies would, in time, appear as distinct species, each having its own definite, persistent, unvarying characteristics.

The matter of the bird's individual plumage seems to have definite relation to its environment and its plan of food-getting. Colors of plumage seem to be deceptive, protective, and attractive. Birds spending the life round in one region, frequently have a winter and a summer plumage. The ptarmigan in its winter home on the mountain slopes is snowy white, and in summer, brownmottled. This is protective coloration. But the snowy owl, which lives in about the same regions, is snow-white in winter also; and often makes a meal off the ptarmigan because of this fact. This is deceptive coloration. Fruit-eating birds are often brilliantly colored to keep you from seeing what they are doing. Not that they know that you like fruit better than they do, or are better entitled to it (either fact need not be conceded), but as animal against animal in the struggle for getting enough to eat, when they are best nourished by fruit, they are best assured of getting enough of it by being fruit-colored. 
With exceedingly few exceptions, the male is more brightly colored than the female. He displays his brightest colors at the opening of the mating season. This seems to be for the attraction of the females, and it is perhaps an example of egoism. The most attractive male would be likely to attract the most desirable female for the strongest nestlings. Not that either has the power to reason it out that way, and see the desirable end before the impulse to action, but the instincts of the individual tend in this direction. Living begets the habit of living, and that living is naturally to the fullest extent of the individual's powers. 


\section{CHAPTER XXIII.}

\section{MIGRATIONS AND NESTING HABITS.}

\section{Migrations.}

This is, of all bird habits, the least to be accounted for biologically or on any other grounds. Migrations are not helter-skelter movements, but are like the wellplanned march of an army under excellent generalship. The impulse that starts the birds north at the approach of spring in the Southland, or the impulse that sends timid birds over far reaches of country, across vast bodies of water, are hardly to be explained by the single fact of obedience to the instinct of food-getting. Climatic changes, as well as seasonal changes must have played their part. Changes in continent configuration, through upheaval or subsidence, may have occurred slowly enough to establish the habit of travelling a certain route in the periodic migrations. These movements are not simply north and south movements, but many of the migrating birds take an east and west course. Habit plays an important part; the route once established, the bird tends to retrace its path, whether it is the short route or not. But the formation of the habit is the inexplicable thing. If we call the place where the birds raise their young home, then leaving may be brought about, possibly, by the stronger instinct of food-getting; while returning to it is the rising of the first instinct again into dominance; or it may be that it is simply the desire of the individual to bring about harmony between its desire and its sur- 
roundings - the raising of young in the region that yields food abundantly.

Many naturalists and some biologists have discussed the subject with profit. Mr. William Beebe, in his interesting book, "Two Bird Lovers in Mexico," well describes this wonderful periodical journeying back and forth of the birds. He visited the Mexican lake mentioned in March of a Mexican winter:

"But Chapala honors us with a final farewell. The sun is sinking in a cloudless sky, a wind rises from somewhere, ruffles the face of the pools, and brings the scent of the March blossoms to us. A small flock of whitefronted geese passes rapidly overhead, not very high up, when all at once there floats into view cloud after cloud of purest white, stained on one side by the gold of the setting sun. We dismount and look up till our bodies ache, and still they come, silently driving into the darkening North. The great imperative call of the year has sounded; the drawing which brooks no refusal. Our letters from the North tell of snow and blizzards-the most terrible winter for many years. No hint of spring has yet been felt there, while here in the tropics no frost nor snow has come through the winter, food is abundant, hunters few; yet a summons has pulsed through the finer arteries of Nature, intangible to us, omnipotent with the birds. Until dark, and no one can tell how long. after, the snow geese of Labrador, of Hudson Bay, of Alaska, perhaps of lands still unknown, speed northward.'

Nor is the bird tribe the only one that migrates. Lemmings, rats, grasshoppers, monarch butterflies, green bugs, chinch bugs, salmon and many others of the fish kind, migrate. The human tribe is not without its records of historic migrations, to say nothing of those 
great movements, not understood except as to their results in peopling lands now widely separated by oceans. The Crusades and the assembling of the Pilgrim fathers upon our own shores, offer two great illustrations of this tendency of the human family to migrate. In the whole range of the animal kingdom the individual must have the inner feeling of satisfaction with his surroundings, or there will crowd upon him the irresistible impulse to find satisfactory surroundings elsewhere. With the human family, this feeling may arise through reasoning out the non-beneficial results of a particular condition; with the animals below man, the impulse to migration must be less a matter of mentation, and predominantly a matter of physical, bodily, discontent. Still, with the highest of the lower animals, there must enter the first stirrings of the impulses that are mental in the animals a little farther up in the scale of life.

The sexual instinct must play a large part in the migrations of birds. This instinct may be regarded as the expression of the desire of the individual to live on. Failing this possibility within himself, then to live in his offspring; and from this latter feeling may arise the desire to place the offspring in the most desirable conditions possible, at whatever cost to himself.

Birds staying in one region the year round must, if it is in our latitude, temperate, change their fare with the season. But birds that are dependent upon one kind of food, as fruit, must migrate to find it. Insecteaters must also migrate to follow up the insect hordes. Most migratory birds of the western States pass the winter in Mexico and Cuba. The same general statement may be made for the birds of the eastern United States, most of them go south for the winter. Many of the 
birds nesting in the states east of the Alleghanies simply find their more genial winter conditions in our southern states, and do not leave the United States. The purely insectivorous species may cross the channel to Cuba and winter there, or in some other of the West Indies. Some of the birds of both East and West go to Central or South America. Many of the eastern sparrows, the bluebirds, and the robins of the eastern States usually winter from the Middle to the Gulf States. The bobolink, one of the birds rarely seen west of the Missouri river, is an illustration of habit in migration. The bird winters in South America. It enters the United States on its northward journey, by way of Florida, comes northward through the Eastern States, and from there strikes westward to about the Mississippi line; then goes northward to Michigan, Wisconsin, and eastern Minnesota and Manitoba, where it nests. In the autumn it reverses its path but follows the same zigzag course, bidding farewell to the United States at Florida's southern coast on its way southward to its far South American winter home. This is also one of the few examples of the two sexes, migrating separately; the males, flying in large flocks, precede the females by several days.

Any observer of bird life in the plains states and east of the Rockies, knows that the conditions for birds have changed wonderfully in the last fifteen years, or even ten. The homestead laws, beneficial to the settlers willing to become pioneers in the wild, unsettled western country in the early years of the half-century preceding this, bore part of their fruit in the spread of birds into the regions thus occupied. Gradually, many birds have been encouraged to stay all the year, where food and shelter have offered. The robins, the Kentucky cardinal, the blue jay, 
the meadow lark, often winter through where formerly they went southward under the stress of food lack during the cold season. In the vicinity of settlements, villages, or towns in the Plains States, anywhere from thirty to forty species of birds may be found during the winter. Some of these are winter visitors from the north, and others are birds that have been changed from summer visitors to permanent residents.

These winter birds do an amazing amount of good in the eating of weed seeds, and of winter forms of insect life, eggs, grubs, and hibernating, skulking adults. In Lapland, Norway, and Sweden, the winter birds are provided with food by tying grain stalks and other seedproducing plants to tall poles or to tree branches. Dwellers in new agricultural communities might, with great benefit to themselves, follow the custom, especially during the seasons when excessive snows cover the usual food supply.

As to their times and seasons of migration, birds are to be classified as:

All-the-year-tounds, birds staying the year round in a locality.

Summer residents, birds staying during the summer only and going back to their southern home at the approach of cold weather.

Winter residents, birds coming from the north in the fall and going back to their northern homes in our spring.

Transients, whose winter home is south of the given locality, and who go north for the nesting season, returning again across the locality at the approach of northern winter. 
Timid birds, or the smaller birds, as the wrens and the vireos, travel by night and feed by day. Bold, strongwinged birds as the robins, the blackbirds, and some of the larks fly by day or night, can go long distances, and so can afford to stop sufficiently long where food is abundant. In good weather, migrating birds fly high, and often follow some guiding feature of the landscape, a river line, particularly, with its promise of food and water; though they seem also to be guided by mountain chains. There is little doubt that coast lines are a large factor influencing birds in their migrations. Usually fogs or storms bring them lower, probably to seek additional guiding features of the country over which they may be passing; though it is true that sight alone will not suffice to explain all the marvelous activities which we witness across the country every spring and autumn.

Whatever the guiding sense may be, old birds seem to possess it in greatest perfection. It is likely that many young birds making the trip for the first time fall by the way; but those who survive have "learned how" by the next year; and thus a permanency of leadership is kept up which becomes a strong factor in the continuance of the life of the individual within the species. Whatever the sense by means of which the birds maintain their direction of movement toward a fixed point-we call it orientation - fog seems to produce much the same effect upon them as it does upon us, when it shuts out the familiar landmarks. Man, as a traveller, is perhaps the most helpless of all animals. Before the invention of the compass, he stayed close home; and it was indeed a hardy soul that ventured on the sea far from the home shore. Blind-folded, he travels in a circle; or lost on a plain, he travels again and again the 
round of his own steps. Let him pass from the streets of a town into a pathless field, and he will be quite likely to lose his way unless he sees some objective point and keeps it in view. He seems not to possess now, if he ever did possess, any inherent sense of direction with respect to himself. This sense of direction is possessed by many of the lower animals, and by some of them in a marvelous degree.

\section{The Nesting Season.}

Spring in every clime is the nesting season for birds. This does not mean April or May the world round. On the other side of the equator, it is September and October. Spring, with migratory birds, means the season of plant growth in their nesting homes. In the tropics, although it is warm the year round, the nesting season is as well defined as it is in more northern climes; there it occurs with the return of the tropical rainy season, the time when fruits and seeds are abundant, and insects are abroad in search of either or both. Among temperate latitude birds, the birds whose young are fed on flesh are the first birds to nest, while fruit- and insect-eaters nest later. In the middle latitudes, the domestic pigeon may nest earlier than even the flesh-eating birds; occasionally young broods are heard in January, if the winter is an open winter.

In the choice of a mate, birds display traits surprisingly, sometimes mortifyingly, human. The believer in the theory of natural selection will find abundant material for study if he will observe birds during the mating season. For any given season, the rule for the union of birds is monogamy, and polygamy is the exception; and so far as present knowledge goes, the choice of 
a mate, with many birds, covers a period as long as the life of the birds. It is believed of the eagle that his choice of a mate is a life-long choice. The English sparrow is believed to be polygamous, and our domestic fowls are also. The bob-whites are monogamous, a dual union being an exception among them, although they belong to the same order of birds as do our domestic fowls.

The number of eggs in the full set for different birds varies from one to twenty. The young of some birds are hatched with a full covering of down, and can run about or swim from the time of hatching; such birds are called præcocial. Of other birds, the young are hatched naked and helpless, and must be long fed and nourished in the nest; these birds are called altricial. Such birds are in a much less advanced condition than are the præcocial birds, and the nest becomes a home where the development takes place under the care of one or both parents. This fact has biological significance; the longer the time of development from birth to maturity, the greater the degree of complexity which may be reached, and the higher the position of the animal in the scale of life. In accord with this fact, we have within the class Aves, a possible ranking of the families of birds; and we shall find that the birds of highest nervous-organization are the altricial birds, while the præcocial birds plainly rank lower in the bird scale.

The period of incubation is the period intervening between the laying of the eggs and the hatching of the young birds. With some birds the eggs are left loosely covered but exposed to the rays of the sun, the loose covering serving to prevent undue radiation at night. With many birds the eggs are covered by the female, the male during the entire time taking upon himself 
the care of feeding the sitting bird or repairing the nest in case of accident. Among the highest birds within this class, the male in addition to the duties just mentioned defends the female from enemies and seems to try to encourage her in her long task by his songs, his presence, and his manifest attentions beyond those necessary in the way of feeding her. If affection exists among birds, that is, affection in its accepted human meaning, the conduct of birds during the time of home-building and caring for the nestlings, is to be interpreted adequately only on the basis of affection of a degree which is commensurate with the advancement of the bird in the scale of living. Among the highest order of birds we have numerous illustrations of the interestedness of the two members of a bird household in each other. Anyone who has ever had the pleasure of watching a pair of owls, knows that one seldom sees so genuine a display of affection among the human tribe.

In others of the bird tribe, the female has to take the brunt of the burdens of incubation, the male taking her place only a short time, while she is off feeding. From this, the conditions vary until finally, in such birds as the phalaropes, there is such a division of labor that the care of the eggs and of the young also falls upon the male bird. Truly, the male phalarope seems to be the "new man" among birds; and the female bird is surely the "new woman," so care-free a life does she lead while her mate is at home busy with home duties!

The ostriches, largest of our living birds that have a keeled back bone, share the home duties; the male assisting in covering the eggs in their sand-hollowed nests. The wood duck, handsome fellow that he is, leaves the incubation and the care of the young to his mate. It is 
a rare thing for the domestic cock to pay any attention to his offspring. It really seems to be a matter of condescension on his part when he brings some choice morsel of food or an insect to the attention of the overburdened hen mother with fifteen or twenty little chicks.

As to the feeding and care of the young, about the same individual differences hold good; though for the majority of birds both parents share in the feeding of the young birds, at least to some extent. In the higher orders both parents seem to have equal solicitude for the safety and comfort of their young. And it is certainly no easy task to fill the gaping mouths from daylight to dark. Sometimes it is a fine, fat, juicy worm, or a piece of a berry; sometimes it is a half dozen seeds beaten to a pulp; or some other dainty, regurgitated morsel from the parent crop; or perhaps it is a little fish dropped down the willing throat. With præcocial birds the training usually consists in showing the young birds where and how to find food for themselves. You have doubtless seen a mother duck teaching her ducklings to spoon up the mud from the bottom of the pond for insect larvæ and juicy water plants; or the domestic hen showing her chicks how to make the dirt fly in the weed patch, or in the mellow garden-good angleworm ground!

June and July are the high tide of the nesting season with our temperate latitude birds, and on some especially hot afternoon one may be surprised to find some mother robin, catbird, or cedar bird astride her nest, with wings half extended, thus attempting to shield her nestlings from the sun, and at the same time give them air.

As to their notions of cleanliness, birds adhere more or less closely to standards, which also seem to vary with the nervous development and the advancement of the 
birds in the scale of life. Here, again, they exhibit a resemblance to their human neighbors. We say of one farmer, he is thrifty, his farm is well-kept; of another, he is shiftless, and everything is at loose ends. Housekeepers are slovenly, untidy, or disorderly; or they are industrious, orderly, artistic, neat-the other sort of homekeepers about whom we would prefer to think. These traits seem human and not to be applied to other animals. But it is to be accepted as true that these notions, along with many other traits and powers in this wonderfully complex nature or being of ours, have their roots deeper than the soil in which we grow; and we shall understand ourselves better for studying and seeking out the glimpses, and sometimes clear evidences, of our own powers in animals lower in the life scale than ourselves.

The instincts clustering about home and homemaking, and care for the young, are among the finest of all the instincts. And nowhere, not even the human tribe excepted, are these instincts more clearly in evidence than among the members of the higher orders of birds; indeed the care found among the lower orders of animals is often superior to the care vouchsafed to the helpless infant by some human parents.

With these instincts as with others that have been mentioned, we find various degrees of excellence in the making and tending of the nest. Some birds are slovenly, careless nest-builders, scooping out a hollow in the sand of the sea beach, or pushing a loose pile of drift together to make the hollow in which to lay the eggs. Crows and jays make nests that look as if they might fall to pieces if the female birds did not sit upon them very carefully. Blackbirds' nests are little better. English 
sparrows seem to stand off and throw together almost anything they can find loose and carry off, and will contentedly rear several broods in such a nest in the course of the year; without making any attempt to mend or clean up. When you attempt to take down their nest, it comes to pieces in your hand. Contrast such nests with the nest built by the Baltimore oriole, or the bluebird, the tailor bird, or the dainty, lichen-covered home of the humming bird.

Again, nests, aside from their construction, are filthy or cleanly, according to the notions of cleanliness possessed by their pair of owners. The pelicans and the cormorants have disgustingly filthy nests, the offal and garbage and excrementitious matter being allowed to accumulate; and in the case of the cormorants, its fermentation serves to furnish the heat necessary to incubate the eggs. Crows and jays among our more familiar land birds do hardly any better. In strong contrast with these birds stand the careful robin or the oriole or the dainty cedar bird mothers, who regularly clean their nests of all litter left by the food, or of excrementitious matter; keeping house so excellently that an old nest, with them, usually means a weather-beaten, not a dirty nest. Some birds mend their nests after an accident from a storm or some other happening. Here, too, they exhibit varying degrees of success, as human beings measure success in such matters.

In the matter of personal or bodily cleanliness, birds have varying standards. Some insist upon a clean water bath often and thoroughly performed; some can be quite happy if the bath water is muddy or is not indulged in each morning; while some others are content to find a soft spot in the middle of the road and take a dust bath. If you live anywhere near a water course, it will repay you 
to make a trip to it, timing your arrival so as to reach it and conceal yourself before the birds are astir. You will enjoy a glimpse of bird life at its best; and if you will keep perfectly still so as not to make your presence known, you will see these feathered crcatures freely express their individuality. 


\section{CHAPTER XXIV.}

\section{THE FOOD OF NESTLING BIRDS.*}

While adult birds may be valuable to farmers and fruit-growers at any time of the year, they are more valuable at the season of the year when they are raising their young. And whatever the food preferences of the adult bird, the nestling is quite likely to be fed on softbodied animals such as insects. Also, at this time the body-building processes are so rapid that the food needs of the young bird are greatest and it eats more than at any other time of its life.

The nesting season of birds corresponds to the season of the year when agricultural activities are at their height, and the nests of the birds which are valuable to the farmer are always placed in the vicinity of his growing crops. On an average, most birds raise two or three broods of nestlings in a year, with from three to five in a brood, though the broods of the quails and the owls include more than either of these numbers. In the South a spring clutch of quail's eggs may number as high as thirty-two; but the autumn nestful is rarely more than ten, about what it is in the North. The barn owl lays from five to eleven eggs; the marsh owl about six; while the screech owl may number nine eggs before she begins sitting; the number of eggs for these owls varies from four to nine.

* For much of the material under this heading the author is indebted to various investigators in the Government Department of Agriculture, notably Mr. Judd of the Biological Survey. 
The labor of feeding the young birds, for all the dayflying sorts, begins before sunrise and continues until after sunset; the appetites of the nestling seem insatiable; the meals, as we would call them, often averaging one every two minutes:

Birds which do not change their diet bring up their young on the same sort of food as they themselves eat. For instance, pelicans and terns bring up their young principally on fish. But gulls, some species of which nest in Missouri, Kansas, and Iowa, have developed a fondness for soft-bodied insects and worms, and may frequently be seen following the plow, searching the freshly-turned furrows for fat angleworms. Exclusively insectivorous birds, as cuckoos and swallows, feed their young on insects. Pigeons and doves feed their young on starchy seeds. Seed-eaters and birds of mixed diet, both animal and vegetable, have powerful, muscular, grinding gizzards; and may, in addition, as in the case of our barnyard fowls, mocking birds, and some other birds partly fruiteaters, swallow sand or small pebbles along with their food. Birds lack teeth, and some of them use this means of supplying the lack, thus breaking up the food in the gizzard rather than in the mouth. Those birds that live on insects, worms, or soft-bodied vertebrates, have thinwalled, comparatively weak, non-muscular stomachs.

A further fact is interesting: those birds which in the adult stage live on both animal and vegetable food feed their young on an insect diet. This fact must not be lost sight of in estimating the value of a bird. Whatever the character of the stomach of the parent bird, the nestling has, in most cases, a membranous sack with but little development, and cannot digest anything but the softest and most readily digestible substances. Vege- 
tarian birds, with the exception of the pigeons and the doves, feed their young for a time on soft-bodied insects. The crow blackbird, which in the adult stage is both insectivorous and a seed-eater, feeds its young on soft, plump spiders, young grasshoppers, and small cutworms. The pigeons feed their young on pigeons' milk, which is grain in semi-fluid condition, partially digested in the parent's crop and fed to the young bird by regurgitation.

For the last two sorts of birds mentioned, as the stomach changes, the diet changes; beetles become a part of the daily fare, until by the time the blackbirds are half-grown their stomachs are ready to digest such hard grains as corn. This may be given to them freely, and when they leave the nest, corn may form one-fourth of their diet.

Following is a tabulated list of our most common birds with the nestling, and, in some cases, adult food habits.

Brown Thrashers.-Adults eat one-fourth fruit and three-fourths insects; but the nestlings are exclusively insectivorous.

Mocking Bird.-Adult eats fruit and insects, half and half; but feeds its nestlings exclusively on insects, such as caterpillars, spiders, flies, moths, and butterflies.

Catbird nestlings are fed on fruit to four per cent. of their diet, the other ninety-six per cent being insects, such as spiders, ants, caterpillars, and grasshoppers.

Cuckoos, black-billed and yellow-billed, prefer a caterpillar diet to any other kind, and this is varied with leaf-eating larvæ. One stomach examined contained twohundred fifty caterpillars. The hairs of a caterpillar are usually barbed at the end, and are apt to catch in the soft mucous lining of the cuckoo's stomach; hence the 
stomach of an adult bird often has a lining of these hairs. The yellow-billed cuckoo is called the rain crow. Their nestlings are fed on smooth caterpillars at first, the hairy ones being added later.

Towhee nestlings are fed on long-horned beetles, weevils, crickets, grasshoppers, spiders, and snails.

Grosbeak nestlings are fed exclusively on insects. One nest observed by Mr. Judd was built in a potato field, and the nestlings were fed the larvæ and pupæ of the beetles, and later the beetles themselves.

Sparrows, as a Family.-Taking it by the large, are granivorous or seed-eating, as to the adults, to twothirds of their diet; but their nestlings are insectivorous, eating, as long as they are nestlings, such things as grasshoppers, army worms, bugs, weevils, beetles, cutworms, crickets, earthworms, cabbage worms, and snails.

It may be said of the sparrows and the towhees, both of which feed snails to their nestlings, that this is a service not to be despised if sheep-raising is carried on in the region where these birds nest. The snail has been found to be the intermediate host for the river fluke, that pest of sheep farmers.

English Sparrow.-The adults are insectivorous to only about one-tenth of their diet, according to $\mathrm{Mr}$. Judd's investigations; yet, in the cases that have come under the author's notice, this foreigner is gradually becoming more of an insect eater. Each spring and summer, for the last three years, these birds have been watched eating cutworms. The nestlings, and here is the interesting part of it, are insectivorous to fifty per cent of their diet, being fed grasshoppers, spiders, caterpillars, weevils, cabbage worms, white grubs, and cutworms. 
Red-winged Blackbird.-Both adults and nestlings are seed-eaters only to the extent of one per cent of their diet; the other ninety-nine per cent being weevils, leaf beetles, grasshoppers, and dragon flies.

Kingbird.-The adults feed on beetles, many of them being asparagus beetles and rose beetles, besides horse flies and other flies injurious to stock; and in addition, the adult does much service in driving away crows, sharp-shinned hawks, and Cooper's hawk, all of which, although they are larger than he is, are bravely attacked by the kingbird. He feeds his nestlings on crickets, grasshoppers, moths, and beetles.

Cooper's Hawk; Sharp-shinned Hawk; Goshawk.The adults feed on smaller birds, most of them of great value, and on chickens, quails, grouse, and ducks. The sharp-shinned hawk is one of our smallest hawks, measuring from ten to twelve inches in the male and a little larger in the female. The upper parts are slaty gray and the under parts are whitish. The wings underneath are white and the tail is white at the tip. Cooper's hawk is a much larger bird, but looks very much like the sharp-shinned in coloring. The tail is rounded instead of square. The pictures of these birds ought to be sought, so that one may learn just how they look, for the purpose of recognizing and killing them whenever they are seen.

Sparrow Hawk.-Our smallest hawk; bright reddishbrown on crown, back, and tail; outer tail feathers white, under parts of the body yellowish; some black bars, usually, on head, neck, and breast. This hawk is almost exclusively insectivorous, eating more grasshoppers than most other birds put together, and feeding its nestlings on the same diet. 
Marsh Hawk.--One of the most valuable destroyers of meadow mice and ground squirrels. This hawk differs from most of its kind in that it is almost exclusively a ground bird, flying low to beat up its prey, and even nesting on the ground. Its young are fed on bits of the same food as the adults eat, and on small insects. The food of adult marsh hawks consists of field mice, shrews, and moles, and such other small rodents as may be found.

Adult Red-Tails (often called hen hawks) should bear no such evil reputation. The stomachs of many birds examined, show it to be a mouse eater, varying its diet with the larger insects, small rodents, and reptiles. The stomachs examined in winter contained poultry and game birds in the ratio of fifty-four out of five hundred sixty-two stomachs, nine per cent of the whole number of birds examined.

Barn Owl.--Probably the most valuable rat and mice catcher in the United States. Its nestlings are fed at night when mice are abroad-and people are asleep.

Burrowing 0w1.-Adults eat, and feed their nestlings, grasshoppers, beetles, mice, frogs, snakes, lizards, and crayfish.

Screech owls eat mice and many insect pests; feed their young the same sorts of food as they themselves eat.

As to the owls in general, if the boy or the man who considers them a pest will go to the nests of these birds, he will always find evidence on the ground below the nest. of the nature of the food of these birds. They swallow their food whole and afterward eject through the mouth the indigestible portions, such as bones, hair, or chitinized insect legs, though chitin yields more readily to digestive fluids than do either bones or hair. 
Mourning doves feed their young on seeds of spurge, ragweed, sunflowers, pigeon grass, and corn, all reduced to what is called pigeons' milk. One nestling examined by Mr. Judd had seventy-five hundred sorrel seeds in its crop.

Gallinaceous birds are not exclusively vegetarians as adults, and their young, as far as they have been investigated, are fed largely on insect diet at first. Prairie chickens and quails feed their young on cutworms, army worms, chinch bugs, twelve-spot cucumber beetles, and Rocky Mountain locusts. Mongolian pheasants, now being introduced into some parts of the country, greedily eat potato beetles, are bred for that purpose in some parts of the Middle West. Whether they can be induced to breed freely and naturally in this country remains to be seen.

Cranes feed their nestlings on earthworms and carabid beetles. One nestling two. months old ate seventeen-year cicadas, a quart of them a day, as long as the mother crane's "find" held out.

Warblers eat, as adults, and feed their nestlings, the smaller insects, such as leaf-eaters, both bugs and beetles, and plant lice.

Baltimore Oriole.-In an examination of one hundred stomachs, thirty-four per cent of the food was caterpillars, the remainder mainly other insects, very little being fruit, and that principally of the wild sorts, and no trace of grapes. (John Burroughs accuses the bird of being a grape-eater.)

Chickadees.-Winter food of the adults consists of insects' eggs, such as tent caterpillar and fall canker-worm eggs, winter forms of plant and scale lice, and many common and injurious hibernating forest tree pests. Their 
visits should be encouraged as much as possible. To encourage a bird means to let it carefully alone, and see that other people treat it in the same way. In unusually severe weather, when snow covers the natural food supply of birds, encouragement may mean providing the little workers with artificial food to tide them over until their natural food again offers. For flesh- and insect-eaters, this might be accomplished by hanging meaty bones in trees, as suggested by the National Humane Society. Fastening netting about the meat might slow up the carrying away of the meat by the larger birds and give the little ones a better chance.

Nuthatches and brown creepers perform a service difficult for man to do for himself. The eggs of many of our insects are so small as to escape the closest search on our part; but these tiny birds, chickadees, nuthatches, and brown creepers, are well able to search them out; and in the long cold winters require large quantities of them to keep themselves going. If you see a grayish shadow of a little bird, hustling up and down the tree trunks, giving vent to a shrill, jerky note as it glides in and out of the bark crevices, do not throw a stone at it. Ten chances to one, it is one of these little birds getting its hard-earned dinner, and thus ridding us of numerous pests.

Downy Woodpeckers.-Feed their young on woodboring insects and their adult forms, also on plant lice, scale and bark lice. In winter, the adults search tree trunks for hibernating insects, borers, and insect eggs.

Hairy Woodpeckers.-Seek more boring beetles and fewer ants than does the downy; otherwise the same as the downy.

Flicker.-Two stomachs examined contained three thousand ants apiece. Some of the ants were the wood- 
boring sorts, and the others were like the ants eaten by the downies, the sorts that cultivate plant lice. Flickers also eat borers, but they are much more largely ground birds than are any others of the woodpeckers.

All Mr. Judd's observations showed clearly that, except pigeons and doves, the birds examined fed their young first on animal food, and changed the diet only gradually, and this only when the parent birds were not insect- or flesh-eaters. This is due not only to the fact of the soft, lax walls of the young bird's stomach, but also to the other fact that animal food in general has a higher nutritive value, and is more easily digested by the bird than is vegetable food.

Professor Samuel Aughey gives some interesting figures calculated to show vividly how much a bird may really accomplish in the destruction of insects. He says: "During an outbreak of the Rocky Mountain locusts in the 70's I saw a long-billed marsh wren carry thirty locusts to her nestlings in one hour. At this rate for seven hours a day, a brood would consume two hundred ten locusts per day. And the passerine birds of the eastern half of Nebraska, allowing only twenty broods to the square mile, would destroy daily $162,77 \mathrm{I}, 000$ of the pests. The average locust weighs about fifteen grains, and is capable each day of consuming its own weight of standing forage crops, corn and wheat. The locusts, therefore, eaten by the nestlings would have been able to destroy in one day 174,397 tons of crops, which at \$ro a ton, would have been worth $\$ 1743.97$. This case may serve as an illustration of the vast good that is done every year by the destruction of insect pests fed to nestling birds." (From Report of the Entomological Commission, I900.) 


\section{CHAPTER XXV.}

\section{THE NERVOUS SYSTEM AND SPECIAL FUNCTIONS.}

As in nearly all vertebrates, the nervous system may be divided into the cerebro-spinal and the sympathetic system, with the brain as the front dilation of the nerve axis. Beginning with the lowest vertebrate animals with a nervous axis, the front end of the nerve cord is practically without dilation, that is, there are practically no evident lobes, such as characterize the human brain, for example. In fishes, there are the characteristic lobes, front and rear brain, and olfactory and optic lobes, but of nearly equal size, the optic lobes being somewhat the largest of the four. In the reptilian brain the lobes are of more unequal size, owing to the encroachment of the front brain upon the cavity occupied by the other lobes of the front end of this nerve axis. In birds the front brain partly covers the olfactory and the optic lobes, and is relatively larger than it is in reptiles. That is, the cerebral hemispheres are larger than in any of the animals below the birds. This relative proportion of the four lobes is one of the bases of determining the place of an animal in the scale of life. Of course, there must also enter the proportion of gray matter to white, and the fineness of the matter making up the nervous tract, as well as the comparative size of the four lobes.

There are the familiar twelve pairs of cranial nerves, and, as in man, the number of spinal nerves corresponds 
with the number of vertebræ. The sympathetic system is made up of a double cord, running on each side of the vertebræ lengthwise.

\section{Sight.}

The sense of sight is amazingly developed in birds, seemingly far beyond the power of vision in man, unless it is aided by some faculty which does not come to the aid of the sense in man. The function of accommodation is marvelously developed. You have seen a hawk swoop down with a rush, and yet not fail to reach the prey sought. Such rapidity of change in the function of accommodation in the human eye would be a serious tax. Humming birds fly with more rapidity of motion than the human eye can follow, yet they avoid obstacles and find the flower. You and I have considerable difficulty in locating angleworms, even with diligent digging, before we start off fishing; but a robin will sit on the tree bough, apparently looking about him, and all at once will dart down and complacently pull up a fine, fat worm. The bald eagle up in the blue sees an osprey fishing, and is thereby spared the trouble of getting a meal for himself. The osprey's dash out of the depths of the same aerial ocean to the water surface, just beneath which a fish is swimming, is even more wonderful.

Structurally, the eye consists of the corneal window, the crystalline lens, the iris, the conjunctiva, and the cavity filled by the aqueous humor. Two eyelids are present as in man, and there is also a third, the nictitating membrane; this third eyelid moves across the ball of the eye, at right angles with the other lids, from the inner corner to the outer. Owls, which do not see well in the daytime, sit with this membrane across the eyeball. Threaten to hit 
a hen or a duck, and you will see this nictitating membrane glide across the eyeball.

\section{Smell.}

As to the sense of smell, there is no such acuteness of this sense as is found among the insects. This is the sense of which the human family, also, is possessed in a smaller degree than are many of the animals below man. Some of the birds seem to possess the sense in a greater degree than does man; but in the majority of birds, the sense seems developed to about the same degree as in our own case.

The birds which have the keenest sense of smell are the carrion-eating birds, vultures and buzzards. And even these must be guided largely by the sense of sight in finding their food. They would seem rather to sight their food before they smell it. So far as their habits have been observed, the birds are first seen circling high in the air above the carcass, or they may be seen coming to earth to observe whether some small animal they have sighted is alive or dead. Though the animal may not have moved, that sense is the sense through which the final judgment is made in such a case; this seems undoubted. On the side of the animal which is the object of the quest, the conduct is even more puzzling. Being alive, it seems not to fear the carrion bird, and does not run to cover; but let a hawk come near such an animal, and off it makes to the nearest hiding place.

The black vulture, which is about as tame in some of our southern towns as our own domestic fowls, probably uses smell more than sight in locating its food, since so much of its time is spent on the ground. That a substance may be perceived as a smell it is necessary, at least in 
the animals that smell by means of a localized organ: first, that the substance be capable of giving off minute portions of itself which are so much lighter than air that they move suspended in it, and are readily carried by currents of air. It is supposed that aquatic animals do not smell as airinhabiting animals do; though it is possible that they become sensible of odors by some other means, as by solutions in water. The body membrane, underneath which the branches of the olfactory nerve are spread, must have its mucous surface soft and moist. These atoms of the odor-bearing strbstance, striking this surface and being moistened by its fluids, affect it in such a way as to bring about the sensation of some particular thing, as violets, roses, new-mown hay, fried potatoes, ploughed ground; or to the vulture, carrion, its sense in this respect being keener than the sense of man for the same odor.

As to the smelling organ of the bird, the nostrils open externally upon the upper mandibles; and the nasal chamber back of each nostril communicates with the mouth, smell being connected with taste, as it is in the human tribe. The olfactory nerve enters each nasal chamber by a single opening; and its branches are spread under the membrane lining the chamber.

\section{Hearing.}

Birds rival man in their receptivity to musical harmonies, and in the extent to which they are aroused by musical vibrations of the atmosphere. Quickness and accuracy of hearing are remarkable in the genus of birds to which the mocking bird belongs. $\mathrm{He}$ will render chance notes more accurately than can ninety-nine out of a hundred human beings. Yet a bird's ear is structurally very simple. There is usually no external ear, but some 
ear coverts instead. The drum of the ear is very near the surface of the head. In the middle ear, the complex mechanism found in the human ear is reduced to a single bone, the columella; and the tympanic cavity is connected with the mouth by a broad passageway, instead of the slender Eustachian tube of the human ear. In the inner ear, the cochlea is shorter and is not coiled tightly; neither do the semicircular canals have the position of these organs in the human ear. They lie in three separate planes in the ear of the bird.

\section{Taste.}

The principal organ of taste is the tongue, which is innervated by the glossopharyngeal nerve, whose branches go to the back part of the mouth as well as to the tongue. The sense is intimately connected with the sense of smell.

\section{Touch.}

The beak is the principal organ of touch, although there is a distributed sense of touch, not localized but distributed over the entire body, and having definite connection with the down or feather covering.

\section{Respiration.}

The lungs of birds are not, as in mammals; hemmed into a thoracic portion of the chest or thorax, but are more like the lungs of reptiles. They begin at the apex of the chest in front and extend backward in the upper region of the thorax and the vertebræ as far as the kidneys. They are not lobed nor do they float free, but are fixed in the upper portion of the dorsal cavity, and are covered on the lower side with a membrane or pleura. The air enters the nostrils, but does not, as in the human animal, pass through the windpipe directly to the lungs. 
When a bird breathes, it breathes all through its body, in its many intermuscular spaces, and in many, if not most of, its bones. In addition to these aerating chambers, the pelicans and the cormorants have a remarkable system of intercellular tubes just underneath the skin. This remarkable pneumaticity makes it possible for the bird to accomplish its wonderful flights, calling for huge carbon dioxid excretion, and immense oxygen supply. From the lungs, there extend through the body of the bird, chambers communicating with the intermuscular cavities of the front thorax, the hind thorax, the wings, the abdomen, the legs, and the subcutaneous regions, when they are present, these forming the auxiliary respiratory chambers.

\section{Digestive System.}

The modifications of the alimentary canal of birds are somewhat similar to those of carnivorous and vegetable feeders among the insects. The connection of the tract with the blood circulation, and the manner and place of oxygenation of the food current, more closely resembles the arrangement in man, as birds have a definite circulatory and respiratory system.

The entrance is through the mouth, which enlarges into the.gullet or esophagus. In many seed-eaters, this gullet serves for the retention of large quantities of food seeds until they can be digested. The seed-eaters are among the most nervously organized of the birds, use up the most food, consume the most oxygen, and must eat voraciously to build up after this tissue exhaustion. Pelicans have the gullet enormously enlarged to serve in prehension of their food as well as its retention.

Below the gullet the canal is usually modified into a 
crop, a side extension of the tube. In seed-eaters, this extension is larger than it is in the flesh-eating birds, and is an efficient division of the digestive tract. Here the food is macerated and mixed with such digestive fluids, usually saliva, as are discharged into this part of the tract. In birds which feed their young by regurgitation, this crop is the portion of the digestive tract from which the comminuted and partially prepared food is thrown back into the mouth of the parent bird to be transferred to the mouth of the nestling. Below this crop is the proventriculus, where the foods are peptonized if they are starchy: or the analysis of the proteids is begun here in the case of the carnivorous birds. The food mass with the two digestive fluids from above are then pushed forward into the gizzard or muscular stomach. If the bird is granivorous or subsists upon a mixed diet of hard and soft substances, the movement of the strong muscular walls of the gizzard practically finish the comminution of the foods into a soft yielding mass.

Very little absorbing of the food current takes place up to this point, but from here on the lacteal absorbents communicate with the lining walls of the canal, picking up such parts as are ready for absorption, scantily at first, but in the after-part of the canal, abundantly. From the stomach, the food passes into the intestine, which may or may not be modified into the three familiar portions of the human intestine. At its upper end, the food receives the digestive, chylifying fluids of the liver and the pancreas. In the lower part of the intestine, the food may be retained in lateral dilations of this large intestine, called crea. The lacteals communicate abundantly with these cæca, and increase enormously the amount of prepared food which thus may be absorbed, by 
THE NERVOUS SYSTEM AND SPECIAL FUNCTIONS. 303 reason of so large an increase of absorbing surface. Such small part of the food mass as is not absorbed here, passes out of the body by way of the rectum and the anus.

Such prepared food as is gathered from the alimentary canal by the lacteals and papillate absorbents of the lining wall, by way of the lymphatic conductors, is emptied into the thoracic duct and then thrown into the blood circulation, to be oxygenated in the lungs, much as the same process is accomplished in man. 



\section{ORDERS OF BIRDS (COUES).}

Passeres, the perching, sparrow-like birds.

Picariæ, birds of such nature as the cuckoos and the humming-birds, very much unlike each other, but also quite unlike the passerine birds, and really put into a class together because they will not fit anywhere else.

Psittaci, parrot-like birds.

Raptores, the birds of prey.

Columbæ, doves and their relatives.

Gallinæ, the game birds.

Limicolæ, the shore birds.

Herodiones, the herons and the stork-like birds.

Alectorides, the swamp or marsh birds.

Longipennes, the long-winged swimmers.

Lamellirostres, duck-like and goose-like birds.

Steganopodes, seashore birds with full-webbed feet.

Pygopodes, diving birds. 



\section{CHAPTER XXVI.}

\section{PASSERES.}

\section{Perchers Proper-Altricial Birds.}

This order includes about half of all the known birds. Their range is from tropical to arctic regions. Practically all the countries of the known world have their characteristic Passeres, while there are some genera that are practically common to all. This is the order of the robins, the thrushes, the catbirds, the sparrows, the crows, and the jays.

The feet are perfectly adapted for perching, first, by the strength and position of the hind toe, and by the fact that it can be placed opposite to any one of the other toes, much as the human thumb can be apposed to any one of the fingers. (Fig. I07.) No one of the front toes is capable of being turned backward, and all the toes are separate to their hases. With one exception there are always four toes, and the bird which makes this excep-

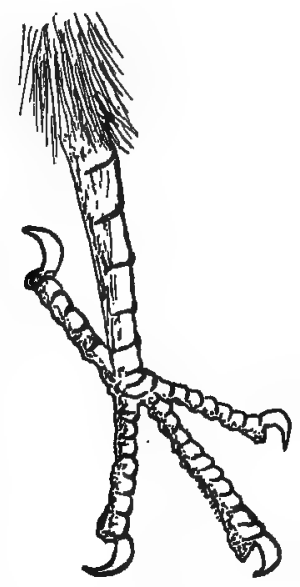

FIG. 107.-Typical passerine foot. tion does not appear among our birds so it need not give us any trouble. The passerine foot comes nearest to the human hand in the range of its adaptability.

The Passeres were named by Cuvier in 1798 ; the name is the plural of the Latin noun, passer, meaning a sparrow. The group with its present limits was estab- 
lished in 1829 . The birds included represent the highest type of physiological development among birds.

With respect to the respiratory system, birds rival man, having a more complicated system than does the human animal. Some of the animals below the birds are cold-blooded; the blood of some of them is oxygenated only periodically; of others, only a portion of the blood is aerated. In those animals where the blood is oxygenated continuously, the consumption of food is most rapid, and the temperature is highest. The body temperature of man is ninety-eight and forty-six hundredths; but for birds, body temperatures range from one hundred four to one hundred ten. Literally, these are the hotblooded animals. In the Passeres, the highest range of the temperature is reached. Nothing could convince one more fully of these facts than one of these little, nervous, frightened wild birds held in the hand. The heart, pounding rapidly against the hand, seems about to spill the life blood of the tiny feathered creature, as the result of the extreme nervous tension under which it is suffering. The Passeres consume the most oxygen and live the fastest, that is, under the heaviest tax upon the vital organs, of all the birds.

The order is divided into two sub-orders on the basis of the degree of development of musical apparatus in the throat. In one sub-order, the Oscines, the musical apparatus reaches a more or less high degree of perfection. Several pairs of additional muscles are used in the production of the sounds made by the bird, giving to the birds forming this sub-order a range of musical ability not equalled by the other orders. In the second sub-order, the Clamatores, literally the crying birds, the musical apparatus is not so highly developed. 
In all the families of the order, there are nine or ten primaries, and the secondaries are more than six.

The birds are all insectivorous or granivorous,

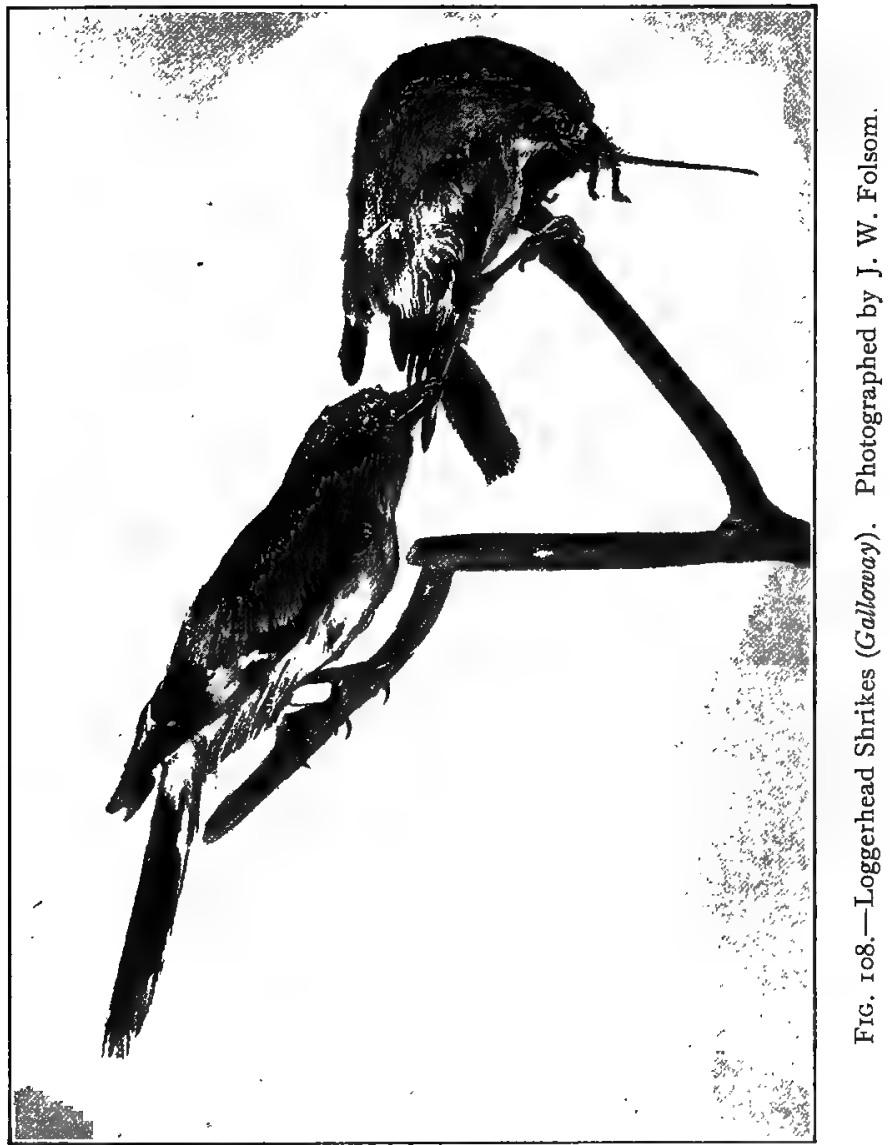

though some of the species ask fruit as a reward for killing scores of insects. Yet it is notably the insectivorous order. Other orders combine this food with 
other foods (Fig. I08); some do not eat insects at any time; and there are a few birds in this order which do not accomplish the full amount of good which might be expected of a passerine bird.

The English sparrow came to the United States in $\mathrm{r} 885$, as an unwelcome visitor. $\mathrm{He}$ is quarrelsome and often drives away our valuable birds; his wife is a dirty and slatternly housekeeper; and when one of the tribe has his feelings ruffled in the slightest degree, all his kin within telegraphing distance assemble to do him justice. Nevertheless he is not to be seized by the scruff of the neck and thrown out bodily, for he is learning a little bird sense in his new environment, and is doing some good to crops on his own account. Here is a list, up to present date, of his accomplishments, American accomplishments; and whatever he does, his wife does; for, although she is possessed of considerable individuality, she follows her husband's lead, as all dutiful wives should.

Nestlings.-Insectivorous to fifty per cent. of their diet; are fed on grasshoppers, spiders, caterpillars, weevils, cabbage worms, white grubs, cutworms, ants.

Adults. - Insectivorous to one-tenth of their diet; eat the same insects as do the nestlings.

In their relations to winged ants, and the termites, which closely resemble winged ants, the English sparrow, aside from the flickers, the downies and the hairies, is more beneficial than are most other birds. The writer came across a stream of these termites going up the side of a building that was being remodeled. And close on them was a flock of English sparrows picking them off with the utmost haste and diligence. Not a sound was heard from the little birds except the soft whirring of their wings when temporarily disturbed by the passersby. 
This occurred on a main thoroughfare of the town; but the hungry sparrows returned to the feast again and again, ridding the place of scores of these wood-boring pests.

On the whole, this is the order of birds most beneficial to man, coming closest to him in point of nervous organization, asking most of him in the way of protection, and returning most to him in service. It is a fact running through the animal kingdom, all the way up from the amoeba to the most highly organized race of the human tribe, that the animal high in nervous organization has less effective means of defense physically. Hence there should exist between man and these nervous little birds the closest sympathy and a spirit of mutual helpfulness. It is there, on the part of the passerine birds; and if man would have an effective ally in his farming and cropraising generally, not to speak of his place of abode being kept comfortably and normally free from noxious pests of many kinds, he will cultivate in himself, if it is not already there, a feeling of dependence upon these valuable servant-friends, and will seek to protect them in every way possible. A bird's life is not to be taken lightly; it is of the same sort as yours, with the germs of many of the same high sensibilities as you yourself possess. 


\section{CHAPTER XXVII.}

PICARIÆ.

\section{The Odd Group-Altricial.}

This is a group of birds of highly diversified forms. They are put together because they differ from all other birds, rather than because they resemble each other. The order includes all the birds below the Passeres, down as far as the parrots and the birds of prey. The distinc-

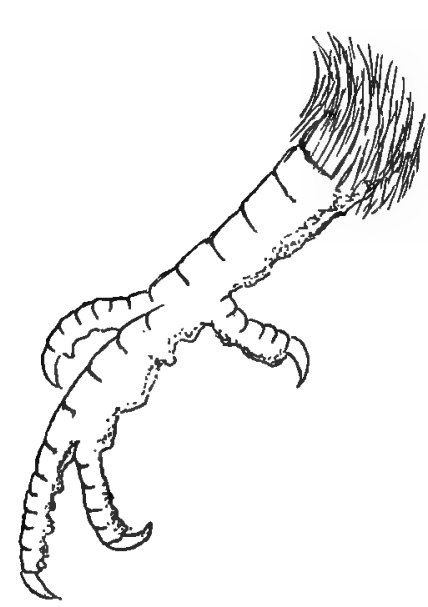

FIG, Iog.-Syndactyle foot of a picarian bird.

tive characteristics cannot be stated as they were for the Passeres, because the birds have no characteristics that are common to all of them. The order includes such widely different birds as the woodpeckers, the cuckoos, the humming birds, and the night hawks.

The feet are variously modified to serve as many plans of food-getting. The hind toe is usually smaller and weaker than the other. toes, and cannot be apposed to any of the other toes. One or another of all the toes can be turned in a direction opposite from the direction of the toes in the passerine foot, and in various members of the order one sees these various positions assumed 
by the toes. The claw of the hind toe is smaller than the claw of the middle toe; at least, it is not larger.

The wings, endlessly variable in form in the different representatives, agree in having ten primaries, of which the first is rarely so reduced in length as to be called spurious or even very short. An exception to this point just stated occurs in the division of the woodpeckers, Pici, where there are but nine developed primaries. The greater wing coverts are at least half as long as the quills that they cover. The number of rectrices is never more than ten, occasionally there are eight.

The bill assumes some of the most extraordinary shapes, but is never cered or hooked nor swollen at the nostrils. The food habits of the Picariæ are as various as the families composing the order. The cuckoos are insectivorous; the woodpeckers are almost exclusively so, although the red-headed woodpecker does not object to a fruit dessert after digging out a hundred or so grubs. The whip-poor-wills are insectivorous, and their hunting begins when the work of other birds ceases. The goat suckers or night hawks, the swifts, and the humming birds are also insectivorous. The trogons and the toucans, tropical birds, are frugivorous, or fruit-eating. The kingfishers have two branches: one of them insectivorous, and the other carnivorous, that is, fish-eating. (Fig. I Io.) The small Texas kingfisher fishes on dry land for the numerous grasshoppers which are to be found in the grain fields. The kingfisher nests are hollowed out in the steep, perhaps rocky, bank of some canyon or stream side. The burrow may be two or three feet deep and is dug out by the bird.

Chapman says that woodpeckers are found everywhere in the world except on the two islands of Madagas- 
car and Australia. They are surely very widely distributed in the United States; they are usually colored so that they are easily recognized, and, with the possible exception of the yellow-bellied sapsucker, should be carefiully protected. Much has been said previously of the

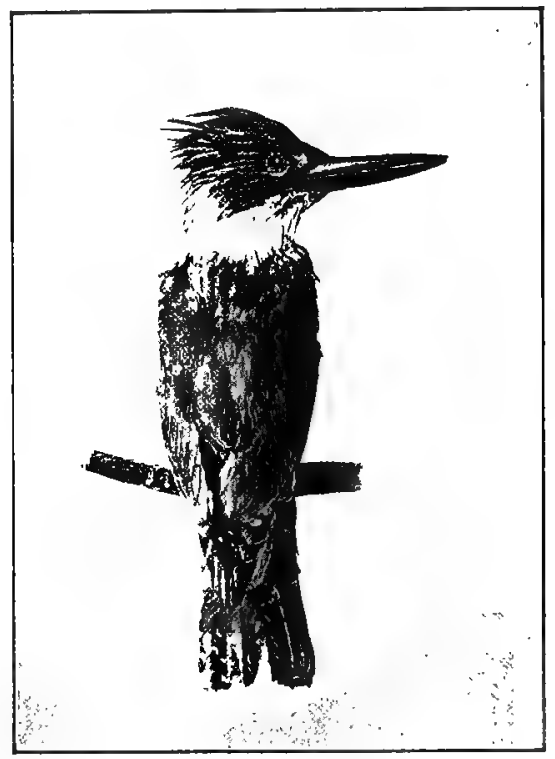

FIG. Iro.-Belted Kingfisher (Galloway.) Photographed by J. W. Folsom.

beneficial food habits of the numerous tribe of woodpeckers; but too much cannot be said to impress their good qualities on the mind of the general public. The downy and the hairy woodpecker, even in our northern latitudes, stay with us all winter, and work the year round, hunting borers when the trees are not frozen; and joining the nuthatches in their search for insect eggs in bark crevices and out-of-the-way places, in the coldest weather. 
The humming birds are likely to nest together in some tree or bush which is in blossom; woodpeckers are rather more likely to nest solitarily; and once in a while one specially quarrelsome pair will dispossess another weaker pair of woodpeckers and appropriate their nest. The cuckoos of the New World, while closely related to the cuckoo of Europe, have not the reputation for laying their eggs in the nests of other birds, which is the usual habit of the European bird, and only a very exceptional thing with our cuckoos. This lazy habit of the European cuckoo seems to have been bequeathed rather to our cowbirds, near relatives of our blackbirds. Farther south, along the Rio Grande river, are found the Savannah blackbirds or Anis, and in Mexico, the groove-billed ani; these birds look like a very slender blackbird, but their bills are much stouter. The groove-bill has the blackbird-like habit of associating in flocks, and feeding on cattle ticks, which they pick off the cattle while the cattle are grazing. The Savannah blackbirds are communistic in their nesting habits; several birds uniting to make one nest in which the several females lay their eggs. 


\section{CHAPTER XXVIII.}

PSITTACI.

\section{Parrot-like Birds-Altricial.}

This is the order of the parrots, the lories, the macaws, and the cockatoos, and is one of the most individualized of the groups; that is, its members are easily recognizable. They are social birds, nesting and feeding in companies. The Carolina paroquet was in earlier times a resident of the Gulf States and spread northward into the states of the lower Mississippi, and has been found as far north as Kansas, but is now nearly exterminated in the northern part of its old range. We are informed from old records that it extended as far north as the Ohio river in I86I. Farther back, in I780, Barton recorded the fact of having seen a flock near Albany, New York.

The birds of the order have highly colored plumage, and most of the representatives show strongly contrasting colors. (Fig. I I I.) The toes are zygodactyle by the turning backward of the fourth toe. The bill is stout, short, and more or less hooked; and at its base a growth of skin covers the horn of the beak, making what is called the cere. The tongue is thick, fleshy, and somewhat prehensile, objects being grasped between it and the upper mandible. The upper mandible is more freely movable than in other birds, being jointed to the front bones of the head instead of being an extension of them. The bill is freely used in climbing. The lower larynx is peculiarly con- 
structed, being provided with three special pairs of muscles.

As to their food habits, the birds may be called the frugivorous raptores; and in some respects, they resemble monkeys among mammals. Parrots abound in all the tropical countries. But the Indian and the Ethiopian regions are poor in parrots, indeed the poorest; while

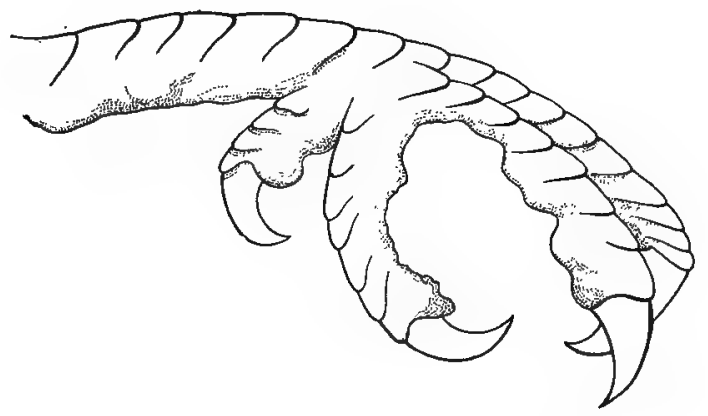

FIG. III.-Zygodactyle foot of a parrot.

the Australasian region has the greatest number of them and perhaps the most species. The parrots which are generally put on sale in the United States are Mexican or Cuban, or rarely South American parrots. In their native haunts, they cannot talk, but are as silent as any wild birds may be, even more so, for their few notes are shrill or harsh, and not to be called singing in any degree; nor do they give a hint of the capacity with which cultivation may endow them. 


\section{CHAPTER XXIX.}

\section{RAPTORES.}

\section{Birds of Prey-Altricial.}

These are the birds of prey, and comprise the eagles, the vultures, the hawks, the falcons, the kites, the buzzards. and the owls.

The young are downy at birth, but must be long fed and nourished in the nest; in some ways, they are even more helpless than are some of the passerine birds. The mother eagle has often a harder time to teach her eaglets to fly than falls to the lot of the tiny humming bird mother; occasionally, the eaglets must be pushed over the side of the nest and compelled to use their wings. In the typical families, the structure betokens strength and activity, ferocity, and carnivorous food habits. But in the smaller, weaker species the diet is mainly insectivorous; other species feed upon reptiles and fish, but the majority enjoy a flesh diet and capture their prey in open warfare.

The wings are broad and ample, and the coverts are long and numerous, covering about three-fourths of the folded wing. The bill is cered like the bill of the parrots, but the feet are not zygodactyle. The tail is variable in form, but has twelve rectrices. The alimentary canal varies within the order according to the families. Among the owls, the alimentation is so regulated that indigestible portions, such as hide, bones, or feathers, are formed into pellets in the stomach and disgorged through the mouth. 
The eagles, falcons, and the hawks capture their prey on the wing by striking it with their enormously developed talons, the most deadly weapons possessed by any birds, and weapons to be feared by man. There are but eight sorts of vultures in the western hemisphere, and only two of these, the black and the turkey, are found in the United States. The black buzzard is sometimes called the carrion crow. The turkey buzzard is one of the land scavengers, and one of the few birds whose services are appreciated. Its life is protected by law in many of our states, and the law is observed without protest; possibly this is due partly to the fact that the flesh of the bird is so strong and ill-flavored that it would never do for a game bird. If the laws that do at present exist on the statute books of the various states, looking toward the partial protection of our game and insectivorous birds, were enforced, crops would be safer, profits would be larger, and men would be more nearly what their Creator intended them to be.

The eagles fall into two groups: those eating freshly killed food, and those whose food is putrefying flesh, or prey not captured in open flight. The first are called noble birds and the second, ignoble. Among our land birds, the eagles have remarkable powers of flight. Some of the buzzards are close rivals, seeming to mount equally high, and perhaps they remain longer on the wing. In South America, the place of the eagles is taken by the condors, whose natural home is the Andean range. 


\section{CHAPTER XXX.}

\section{COLUMBA.}

\section{Dove-like Birds-Altricial.}

The essential characteristic of this order is the character of the bill. This is hard and horny throughout, convex at the tip, and a little constricted a short distance back of the tip. At the base of the bill, there is a membrane which covers the nostrils, and which is soft and elastic while the bird is alive, but contracts and shrinks in mounted specimens. As one looks down upon the bill from above, the feathers sweep across its base in a softly convex line.

The toes are usually not webbed at base, but are in some specimens slightly connected by webbing. The hind toe is on a level with the other toes, as in the passerine foot, and the tarsus is, in most of the birds, shorter than the toes. It is either covered in front with scales of regular shape, scutellate; or it is thickly feathered, or covered by irregularly shaped scales, that is, reticulate. The number of tail feathers is twelve or fourteen.

The habits of the birds are arboreal or tree inhabiting; though there are some ground pigeons. Most of the Columbæ are grain-eaters, and some of them are closely related to the grouse. The fruit pigeons belong to the Malay Peninsula, Australia, and the Polynesian group of islands. They are monogamous in their domestic habits, and both parents seem to share equally. in the nest-building, incubation, and care of the young. The 
pigeons, unlike all other birds, drink much as human beings do, by a continuous draught, swallowing meanwhile, not by single sips, elevating the bill after each sip, as other birds do.

As to the members of this order outside the pigeons and the doves which are common to the United States: in Cuba, there is the blue-headed pigeon, terrestrial not arboreal in its habits. The Nicobar pigeon of New Guinea has long, plume-like feathers covering the body from the nape backward to the region of the secondaries. The Australian pigeons are bronze-tailed, spend part of their time in trees, and part of it on the ground. The African pigeons are more brilliantly colored than our American pigeons, combining green, black, copper, purple, and red-brown as washes or solid blotches of color. In all the countries where the columbine birds are known, some of them are used for food.

The passenger pigeon is known in most countries. It is like the gypsies among the human tribes, here, there, and everywhere. It looks more like our mourning dove than it does like our domestic pigeon, though it is larger than the mourning dove and more brilliantly colored. Formerly it was very abundant in the United States. Their foraging for food became a serious matter; and their nesting-places became a nuisance because of the immense flocks with their disturbing noises and their displacing of other more valuable birds. A bounty was placed upon them; and under its provisions their numbers steadily decreased until now they are rare in any locality. 


\section{CHAPTER XXXI.}

\section{GALLINA.}

\section{Game birds-Præcocial.}

This is the order of the true fowls, the quails, the grouse, the guinea fowls, the domestic hens and turkeys, the pheasants, the curassows, and the guans; the two last-named not being known in the United States. Mexico and the Rio Grande country are the home of the guans.

The order shades into the ground doves of the Columbæ on the one hand, and into the plovers of the Limicolæ, on the other hand. Some of the gallinaceous birds of the Old World are very unlike typical gallinaceous birds. Hence it must appear that the order embraces birds that are far apart as to outward appearance, but are closely related structurally.

These are birds that for the most part have not been able to endure great extremes of heat and cold; hence their migrations have not been such that they are found far north or far south of a given parallel; nor have their most extensive migrations been north and south, but rather east and west. They are also birds that have been closely connected with the encroachments of man upon new and unsettled territory; as he has advanced into new country, these birds have receded before him. The prairie chicken is a bird which has suffered in this respect. In northeastern and eastern United States, it was formerly abundant; but is now exceedingly rare, having been 
driven westward to the plains regions, where the game season, during which it may be shot, is now carefully regulated by law. According to the game law of 1908, the time limits within which the prairie chicken may be legally hunted are from September I 5 to October I5; for bob-whites, the limits are between November I5 and December I 5. In addition, restrictions are imposed as to the number of birds which may be killed by any one hunter, and as to the purpose in killing them. Private property owners may prohibit all hunting on their premises; which prohibitions, by the way, are the most effective game laws possible. The migrating quails of the Old World make migrations across the Mediterranean to nest in the European countries, returning as winter approaches. The Australian quails of the genus Synoicus measure from six and one-half to eight inches in length. These are the smallest of the quail tribe, and make only short migrations, keeping in large coveys. The birds of the order are all terrestrial birds rather than arboreal, like most of the Raptores. They seek their food on the ground, seeds and berries, and therefore are not driven to migration for food as are most of the birds that are insectivorous in their food habits. As with all birds notably seed-eaters, food is usually a matter of all-theyear-round supply in any one locality with these birds; and hence they have, in many cases, followed the grainraising farmer as he has settled in new localities, thus following the westward tide of immigration.

As to characteristics, the hind toe is elevated, except in some of the Old World species; the front toes are commonly a little webbed; the claws are blunt and not much curved; the tarsus is, in most of the birds, broadly scutellate when not feathered. The bill is short, stout, 
and convex, and not constricted anywhere from base to tip. In the region of the nasal fossæ, where the nostrils open upon the upper mandible, the bill is usually soft, but elsewhere it is horny.

All the birds of the order are social as to their own kind. Some birds associate because of the food supply; but these gallinaceous birds have the gregarious habit, gathering in flocks because of common tendencies and needs; and seeming to satisfy their desire by being in company with others of their kind. The domestic birds of the order are good illustrations of these facts. There seems to exist a considerable degree of domesticity, or house and home interest, such as we ourselves possess; the manifest desire to live with one's own kind. Even the occasional hen that "steals her nest," associates with her kind except during the time she is sitting. And so far as the latter fact is concerned, it may be said that at this season isolation is the typical condition for all animals, and especially so for the higher forms of life.

The young of gallinaceous birds are all præcocial with a generous covering of down at birth, and soon are able to find their own food; though the brood stays with the mother for shelter and safety, just as the young of the hen and the turkey are sheltered and instructed by their mothers. Most of the birds of the order are polygamous, the bob-whites forming an exception to this rule. Throughout most of the order the irresponsibility of the male in the care of the young is evident; but to this also the bob-whites form an exception.

Among the bob-whites, the male bird even assists in covering the eggs during the three weeks, usually twenty-three days, of incubation. When the mother bird is on the nest, the male usually does sentinel duty, 
when he is not hunting his breakfast, dinner, and supper. When the young are hatched, if the family is disturbed the male usually flies or runs away. from the place, taking care to remain some time in sight; while the mother bird, having given the danger signal to her nestlings, flutters off in the opposite direction, almost under the feet of the pursuer, feigning lameness, yet striving to lead the disturber farther and farther from the vicinity of the helpless nestlings. She will eventually run or fly to cover; and the disturber of her peace will be left without trace or wing rustle to reveal the whereabouts of the birds so lately visible.

Experiments were made by some of the early investigators, and have been repeated by some later ones, testing the intimacy of relationship, both in reversion and adaptation, existing between bob-whites and domestic chickens. -Bob-whites' eggs were placed under a domestic hen, and a bob-white was given a sitting of domestic hens' eggs. Both mothers hatched their broods successfully. The chickens of the bob-white mother ran about as young bob-whites do; their calls were those of the domestic chicken, but the timidity and response to danger signals, squatting and staying quiet until again summoned, were clearly bob-white-like. Indeed it looked very much as if the domestic chickens were not so far removed after all from the behavior of their wild ancestors before man came among them.

In the other case, it may be first said that young bob-whites are usually readily tamed; and these young birds yielded without difficulty to the hen mother, went abroad by themselves for food, and came at her call. The hen was confined in the coop, so as not to be able to lead nor to be led away. The young bob-whites 
remained with their strange mother until they were nearly grown, sleèping under her wings nights; at this time, they came as usual at her twilight call, instead of going into the coop, they squatted down, bob-white fashion, in a circle, tails toward the center, in front of the coop. Soon after, the "call of the wild" overcame the teaching of the hen mother, and off they went, to return no more.

The wild turkey, ancestor of all the domestic turkeys, is now a rare bird in any locality in North America. It has been hunted so persistently that it is nearly exterminated. It is not much of a credit to the human race, that many animals smaller than man can hope to maintain their existence only by migrating to regions where man cannot follow them.

The plumage colors of the gallinaceous birds are such that they usually are safer in hiding than they are in flight. Many of the birds are ground birds, but even those frequenting trees are equally effectively concealed by their mottled plumage. All the members of the order are somewhat omnivorous, able to subsist on seeds, but securing, whenever possible, insects and green vegetation; and some also relish an occasional meal of flesh. Who has not seen a domestic hen's evident relish of the flesh of a mouse or a mole which some fortunate chance had put in her way? 


\section{CHAPTER XXXII.}

\section{LIMICOL $Æ$.}

\section{Shore Birds-Præcocial.}

This is the order of the snipes, the plovers, the phalaropes, the sandpipers, the woodcocks, and the curlews. - The birds are, on the whole, rather shy, small in size, and the body is rounded or depressed. They are ground birds, living in open places by the water's edge. The head is completely feathered and the plumage is of nearly uniform coloration, at least not with decided. contrasts of colors. The primaries are graduated in length from the first to the tenth; the secondaries also are of uneven length, lengthening from the outside inward; this makes the wing show two decided points when the bird is flying. The tail is, in most of the birds, quite short, and has from twelve-the usual number-up to twenty-six rectrices.

The legs are, in some of the birds, enormously lengthened, are short in only a few genera, and are usually quite slender. The hind toe is, in all the birds, short; and in some of them it is absent altogether. (Fig. II2.) The bill of the different birds varies in length and shape; but in. nearly all of them it is slender and contracted from the front of the head; it is usually as long as the head, and in some of the representatives it is much longer than the head. For most of its length the bill is covered with a softish skin; and in one or two of the different families 
of birds it is soft and sensitive to the very tip, being provided with nerves and bloodvessels.

This sensitiveness of the bill reaches its extreme development among birds as a whole, in the woodcock of the Limicolæ. Here the upper mandible is soft and flexible, cartilaginous rather than horny, and may be moved upon the lower mandible up, down, around, and

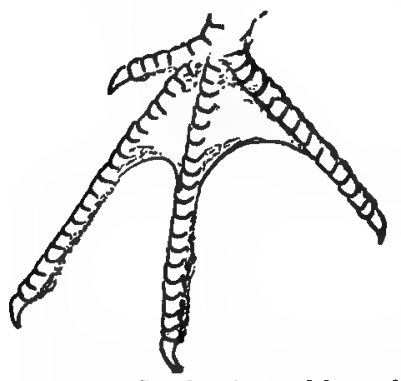

FIG, I 1 2.-Semi-palmated foot of a plover. sidewise, with motions surprising in their freedom. When one has had the rare privilege of watching one of these sobervisaged, grandfatherly birds about his hourly task of digging worms, he will understand the meaning of this. The bird buries its bill up to the head in the soft mud, and cannot use any other sense than that of contact for knowing when it reaches the worm; sight is impossible under the circumstances. This seems true for others of the Limicolæ. The snipes, the sandpipers, and some of the plovers are guided less by the sense of sight in finding their food than are the birds of most other orders; and their bills are less horny, more cartilaginous, and better fitted structurally to serve as sensory organs. This characteristic of finding their food by contact as well as by sight, is shared by the duck tribe, who spoon up much of their food from the pond or the river bed, taking their food "unsight, unseen." In the division to which the snipes and the woodcocks belong, the eyes are set so far back as to be just over the ear openings. The plovers have the eye more nearly in a median position. 
As the name of the order indicates-limus, mud; colere, to inhabit or dwell--these birds are mud-dwellers, ground-feeders, and therefore they all, that is the North American sorts, build their nests on the ground. With the birds that nest near the sea margin, the nest may be simply a depression in the beach and, possibly, formed by the foot and body movements of the bird preparatory to the depositing of the eggs. The birds that nest along the inland water courses bestow a little more care on their nests; they are still hollows in the ground, generally pretty well concealed by being placed at the foot of a tree or some grass clump. Most of the birds line these rude nests with grasses, dead leaves, and mosses, sometimes loosely laid in, sometimes with intent of weaving. The familiar little spotted sandpiper may actually construct a nest, roughly weave it, out of hay and mosses. The green sandpiper, properly an Old World bird, has been noted only twice on the Western Hemisphere; this is the only one of the North American Limicolæ known to nest in trees; where it has been found, this bird nested in trees, in old nests previously used, and presumably nests of other birds.

The long-billed curlews and Bartram's sandpipers build their nests on the prairies at the foot of grassy hummocks or clumps, often far from water; while the other shore birds are true to the typical traits of the order, and nest along rivers, streams, and ponds.

The food of the limicolan birds consists of insects, worms, snails, and other soft-bodied animals picked up from the ground surface or probed for in the soft mud along the ponds or rivers.

Chapman records the woodcocks, the phalaropes, many of the plovers and sandpipers, and the jack curlew 
as nesting freely in the eastern states. Avocets, woodcocks, Bartram's sandpipers, the little spotted sandpiper-a bird of very common occurrence everywherelong-billed curlews, killdeers, and the mountain plovers nest as far south as Kansas in the Missouri valley, and from there breed northward through the northwestern states into northern latitudes as far as Labrador and Nova Scotia.

These birds of the sea-shore and the inland water courses winter from our northern states southward into Mexico, some of them going as far as Brazil. The phalaropes, sea plovers as they are sometimes called, winter to the south of our shores in southern Atlantic or Gulf waters, preferring to spend the time of their winter sojourn on islands rather than on the continent shores.

Like all birds not resident in any given locality, the migratory Limicolæ visit the states in our middle latitudes twice a year, once in May, when they go to their breedinggrounds north, and again in August or September, when the cold weather of the North drives them south to their winter homes. 


\section{CHAPTER XXXIII.}

\section{HERODIONES.}

\section{Herons and Storks-Altricial Birds.}

This is the order of the herons, the storks, the ibises, and the bitterns. Many of them are birds of large size, among the tallest of birds that have a keeled breast-bone. The neck is in most of the birds bent in U-shape. A part, sometimes all, of the head may be naked, and in some of the species a part of the neck is bare also. The toes of the birds are, for the most part, long and slender and are never fully webbed. The bill is long and slender in comparison with the rest of the body, and is wedge-shaped with cutting edges. It is always longer than the head. The tail of the birds of the order has twelve rectrices.

The Herodiones are all of them more or less dependent upon water courses for food, shelter, and nesting needs; hence they are to be found along the inland lakes and rivers. Most of the birds are shy, fearful of man, and so seek those water courses that are heavily fringed with trees and undergrowth, whose turns and secluded windings furnish the degree of retirement that renders them comfortable.

The young are hatched naked and helpless, and are fed and cared for in the nest. The food of the adults consists of fish, reptiles, or other soft, small animals, as snails and aquatic worms, which the bird spears as it stands in wait, or as it stalks stealthily along through the grasses and reeds of swamp or wooded water course. 
Most of the herons are sociable birds, nesting and feeding in large companies. In the United States their breeding-grounds range from Florida through Louisiana, South Carolina, and Texas. They nest also in the West Indies. Herons are peculiar in that they choose to perch and nest in trees, in spite of their long legs and neck, and feet adapted for walking. The night heron builds its nest in trees sometimes as high as thirty feet from the ground. The green heron, or fly-up-the-creek as it is sometimes called, will sometimes manifest enough sociability toward the human family to build its nest in some orchard tree not too far from its water haunts. The herons seem always hungry; they have two interesting peculiarities-patient, motionless watchfulness for something to eat, and an insatiable appetite; and the two fit well together.

The bitterns are solitary rather than sociable birds, preferring to hunt and fly alone; even the birds when paired, prefer to nest apart from their own kind, and not in company with any other birds. Herons and egrets often nest in one immense family, but not so the bitterns. Some of the bitterns place their nests in water grasses or rushes, some in bushes or trees, but always seek concealment.

The American egret ranges from Florida to Patagonia. It is one of the most beautiful and at the same time one of the most harmless of birds. For food, it asks nothing except such fishes and snails as the swampy marshes and lakes of its haunts may afford. And yet it has been one of the most persecuted of birds. During the nesting season, the male bird puts on an exquisite growth of long white plumes covering its slender body from nape to tail tip and is often hunted to the death for the sake of these 
plumes. The home-making instincts and the instincts for the rearing of young are among the finest instincts of which the tribes of animals are capable; and yet the beautiful outward expression of these instincts in the egret have proved its death warrant; it must give up its life, its mate, its young, to adorn someone's head. This is worse than the Indian brave who makes his war headdress of eagles' feathers; his cruelty is to be excused on the ground of his being a savage.

The white-faced glossy ibis winters from Mexico on southward, and in company with egrets and herons breeds in our Southwest, from Texas and the Rio Grande country on through Arizona and New Mexico. All these birds, in spite of their long legs and necks, have extensive powers of flight. On the wing their long legs trail out behind them, balancing the weight of the head in front.

The storks are natives of the Old World. The Jabiru, or American stork, native to Central and South America, is said to have the same habits as the European stork. The Maribou stork of Africa, the carrion-eating stork of the Deccan, the black and green and purple stork of China, are among the Old-World storks. The fish-, frog-, and snake-eating storks of Africa are famous in song and story. The maguari stork is found in Argentina. Thus it seems that the storks of the order are quite well distributed in the countries of the world. 


\section{CHAPTER XXXIV.}

\section{ALECTORIDES.}

\section{Swamp Birds. (Paludicolæ of some Systematists.) Præcocial Birds.}

This order is otherwise called the Paludicolæ- from palus, swamp; and colere, to inhabit. It includes cranes, rails, gallinules, and coots. The birds of the order fall into two types, the crane type and the rail type. The first resemble the herons more than they do the birds of their own order; and the second, while they are very unlike the cranes in body contour, show by their structure that they are closely related to them.

The cranes are all large birds with extremely long legs and necks, and short tails. The head is partly naked. The bill equals or exceeds the head in length, is straight, slender, wedge-shaped, and strong, and is contracted opposite the nostrils. The nostrils are near the middle of the bill and are broadly open. The tibia are naked for an unusual distance, and the toes are short in comparison with the size of the bird and its legs.

Cranes are found everywhere except in Polynesia and South America. North America has two of the few species, Australia has one, Africa has four, and Asia the others. They are gregarious, gathering in large flocks. The cranes living in the northern hemisphere migrate northward at the breeding season. The young of the cranes are præcocial. The nests are rude affairs, raised 
only a few inches above the bog surface. The eggs are few in number, two or three, with rough, warty shells.

The birds of the rail type are small, or of medium size, have compressed bodies, and their heads are completely feathered. The body is so much compressed as to appear wedge-shaped when viewed from the front; this is of extreme advantage to the birds when threading their way through the thick matted grasses of the swamps which they inhabit in search of food, or in flight from some enemy. The thin body itself seems to part the reeds and grasses, propelled forward by the strong legs. The phrase, "as thin as a rail," is not always given its proper relationship to these thin-bodied birds.

The necks and legs of the rails are not unusually long, but the toes are extremely long, and this fact makes it easy for the birds to run over the surface of the wet, oozy ground of their marshes. The birds are shy and retiring, and have a way of skulking along among the reeds and rushes where they hunt their prey. The king rail, the largest of his kind, has a rather comical way of stepping loftily along, lifting his short legs with their enormous toes very high and bobbing his short tail jerkily at every step. When the rails are pursued they seek safety first by running or hiding, and when really flushed they rise feebly and vaguely at first. An observer of them at this time would hardly think that they could make the long flights that they do make every year, and for which they are famous. Their cries are loud and harsh, and they scream piteously when they are caught.

The food of the cranes consists of frogs, snakes, lizards, and field mice. Rails eat crabs, snails and other small mollusks, also grubs, worms, and insects, as well as the seeds and tender shoots of plants. 
The eggs of the rails are many in number and are placed in nests built of reeds and rushes, sticks and grasses, placed upon the ground. Their young are generally black-downy at birth, no matter what the adult color may be.

The cranes as a family, breed in the north, some of them going as far as Manitoba and the Alaska country;

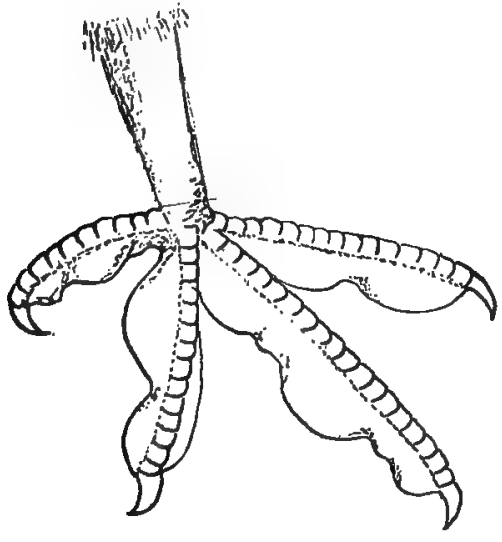

FIG. II3.-Lobate foot of a coot. they winter in Mexico and the Gulf States. Rails and gallinules and coots are more varied in their range, some of the rails migrating as far north as Labrador to raise their young. Coots may go even into Greenland, though they are much more nearly aquatic in their habits than are the rails; their feet reveal this fact. (Fig.

II3.) Coots also breed in the southern and middle part of their range, which extends from Alaska to southern Mexico. The gallinules have a more southern range on the whole, breeding as far north as Massachusetts, spreading inland to the Mississippi, and going south to the Gulf States and well down into Mexico. 


\section{CHAPTER XXXV.}

\section{LAMELLIROSTRES.}

\section{Duck-like and Geese-like birds-Præcocial Birds.}

This is the order of the swans, the flamingoes, the ducks, and the geese. The bill of all the New-World ducks and geese is lamellate with a membranous covering, at least the greater part of the bill has such a covering; the edges of the bill are denticulate in the grass-eaters and sharp-toothed in the fish-eating sorts. The feet are palmate, three of the toes being joined by webbings; the hind toe is elevated, rarely absent. The wings are of medium size and spread, and the tail is, in most of the birds, short and many-feathered. The legs are near the center of equilibrium, and the body is held nearly or quite horizontal in walking. The young of all the birds are præcocial, and many of the birds are polygamous, though this is true of the domestic sorts much more than of the wild birds.

Of these birds, the ducks are world-wide in distribution, and they naturally fall into five sub-orders: the Mergansers or fish ducks; the pond or river ducks; the bay or sea ducks; the geese; and the swans. These differences are based upon structural characteristics quite as much as upon the places of habitation; but these structural differences are rather the apparent reasons for the birds' choice of these haunts; the lines are not hard and fast, however, for there are some sorts of all the kinds 
that may be found occasionally out of their natural haunts.

Taking the order as a whole, the diet is vegetable rather than animal; the ducks that are notably flesheaters, eat also the sea weeds of the coast regions, and the mergansers on our inland lakes do not despise water plants as a variation of their fish diet. The fresh-water ducks and also the flamingoes eat water plants freely. The bill, in both river and bay ducks, has a series of gutters on either side of the inner surface of the upper mandible, which serve as strainers. Both secure their food by dabbling up from the pond or river bottom small mollusks, crustaceans, and seeds of water plants along with the mud; and the mud they get rid of by forcing it along with the water, out of the mouth through these strainers. Geese are more terrestrial in habits than are the ducks, and often visit land to procure grass, corn, or other grains. Among the ducks, the sexes are usually of quite different plumage; among the geese the differences are less noticeable, while the sexes are alike in the swans. Among the flamingoes, the immature birds are white, while the older birds only have the characteristic plumage. The American red flamingo inhabits Cuba and the Bahamas, and is seen on the Florida Keys rarely. Its adult plumage is scarlet, with the primaries and the secondaries of the wings black.

The swans have extremely long necks, are more at home on the water than on the land; they inhabit temperate regions both in Europe and in the United States, breeding from there northward and wintering from our southern border on south into Mexico. But two sorts are known in the United States, the whistling and the trumpeter swan. The whistler is the smaller of these 
two, measuring less than five feet in length; it breeds in the Arctic regions and winters much further south. The trumpeter nests in some parts of our northern border states, as Dakota, and from there northward. The nests of the whistler are ready-made grassy depressions; but the trumpeter constructs a nest out of feathers and down, intermingled with hay. Both these huge birds are seen in the Mississippi valley as they fly to and from their nesting grounds.

The Lamellirostres are migratory birds; as a whole, with the exceptions of the domestic chickens and geese and turkeys; and this is a case where man has been instrumental in bringing about an artificial condition. Cases are on record where some of these migratory wild birds have been detained in captivity till they have been induced to breed there; the young birds have appeared contented until some band of their wild relatives has appeared on the scene, and then the captive birds manifested their desire to be out and away. But the remote generations of these birds, reared year after year, have finally seemed to lose the wild instinct.

The flight of the wild ducks and geese is the most characteristic thing in the spring and fall skies, with their regular $\mathrm{V}$-shaped formations, shifting and changing to suit the layers of air through which they are flying, but never losing the characteristic form. So regular are their habits of migration that they have become weather prophets of no mean order. After a hard winter, everyone will remember the first thrill of spring at the sound of the honk, honk, overhead.

The eider, which is decidedly a bird of the high latitudes, is valued for the down with which the mother lines her nest; it is plucked from her own breast, and the 
plucking of it goes on as the incubation progresses; if need be, the male bird contributes to the downy covering of the six to ten precious eggs. In the northern countries of Europe, Norway, Iceland, and Lapland, the inhabitants make the down a considerable article of commerce; and this is an illustration of the possible enhancement of the value of a bird by the kindly treatment of it. In all the countries where the eider down industry is carried on, the eiders are protected by law from being hunted or disturbed in any way. As a natural consequence, they have grown to be almost tame, nesting in large companies and occupying almost every available space; and the birds will permit the approach of man with very little protesting. The taking of the down from the nests is always done kindly, and the bird has learned not to fear greatly.

$\mathrm{Mr}$. Beebe, in his journeys through the marshes round about Guadalajara, speaks of the notable difference in the behavior of the myriad birds startled by the hoofbeats of his horse from the lake surface to fly a short distance and then return quietly to the feeding-grounds; and the surprised, terror-stricken flight of a flock of mallards or teal from among the decoys of some northern lake. It has been said that the home-making instincts are among the finer instincts which animals possess; and it is to these very instincts among the wild birds that the usual trap methods of the modern hunter appeal. The wooden decoys placed among the reedy washes of the lake, on the migratory track of these wild birds, are gaily painted semblances of these birds in nuptial plumage. Migrations occur at the time when life for the wild fowl is at its fullest tide; and at that time, home and a nestful of young are all the wild bird cares to live for. 
The migrations of these birds, as a whole, cover the entire American continent from Greenland to the Argentine country. Some species are truly Arctic; some species are migratory from south to north; and two of the tree ducks live chiefly within the tropics. The last-named species are found from Texas and the Rio

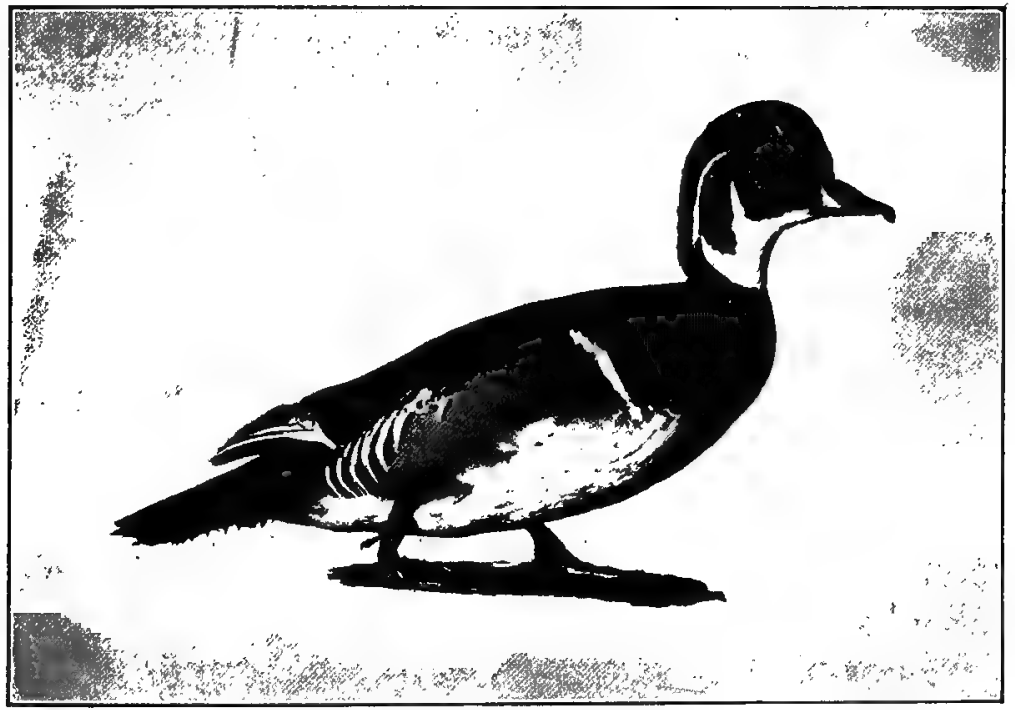

FIG. II4, -Wood Duck (Galloway). Photographed by Dr. J. W. Folsom.

Grande country southward during the spring and summer. They nest in trees; this is an unusual habit with the birds of this order. The buffle-head builds its nest in trees; the foxes are fond of the flesh on its plump little body; hence the bird tries to protect itself by nesting in stumps or trees. The widgeon or baldpate builds often far from water on the grassy upland. The American merganser, or fish duck, nests in some hole in a tree or in a 
hollow which it makes in some cliff side. The wood duck chooses some old nest built by an owl, a woodpecker, or a squirrel; or it may build its own nest but never on the ground, nor necessarily near the water. And part of the duties of the mother duck is to see that the ducklings reach water, carrying them in her bill as far as it may be necessary. (Fig. I I4.) Her mate, who has been very devoted up to this time, will not "raise a finger" to help; only when the fat little ducklings are fairly launched for their first swim, does he appear, and even then his chief aim seems to be to look handsome. He remains on guard, however, during the whole period of incubation, not feeding the sitting bird, indeed, but doing sentinel duty, warning of danger, and singing to her in duck language, often and long at a time.

The mallard is the ancestor of our common domestic duck; and in the wild state, the mallards are monogamous; it is believed that the birds pair for life. 'In their southern haunts during our winter, the birds go in pairs, and assemble in pairs at the feeding-grounds. But with domestication, and the easier, sheltered life, came the degeneracy of polygamy; hence in our poultry-yards, we see the flocks of ducks. 


\section{CHAPTER XXXVI.}

\section{STEGANOPODES.}

\section{Totipalmate Sea Birds-Altricial Birds.}

This is the order of the gannets, the pelicans, the cormorants, the darters, and the frigate birds. Of the order, only the cormorants and the pelicans occur with enough frequency within the limits of the United States to merit discussion here. In I880, a frigate bird was captured in central Kansas, but this was a straggler from some band which may have come a little way inland from Gulf waters, and by storms or some strange chance, have been drawn out of its course. Perhaps this shows us how the entrance of birds into new regions is begun. The frigate birds are, so far as we know them to-day, strictly maritime birds. This is in the same line with the surprise which one of the groove-billed anis of the Rio Grande country and Mexico gave Kansas in the spring of 1902, when it appeared, half starved and certainly lost, in a hay field, where it fell exhausted.

This is the only order of birds in which the feet are totipalmate; that is, all four of the toes are joined by a webbing. To make this possible, the hind toe is turned a little to one side. (Fig. I I 5.) The legs are set even farther back than the legs of the Lamellirostres, which fact makes the birds even more ungainly on the land. All of the birds have a gular pouch, and with the pelicans this is used as a dip net to catch fishes. The brown pelicans swoop down from on the wing to catch the fish; but the white pelicans swim along with their curious fish basket held 
with its edge just below the water surface and filling with fish as the birds push through the water. In both cases, after the birds have caught the fish, they lift the head, contract the gular pouch, letting the water run out of the corners of the mouth, throw up the fish so as to let it drop back tail first down the throat. (Fig. I r6.) Their young are

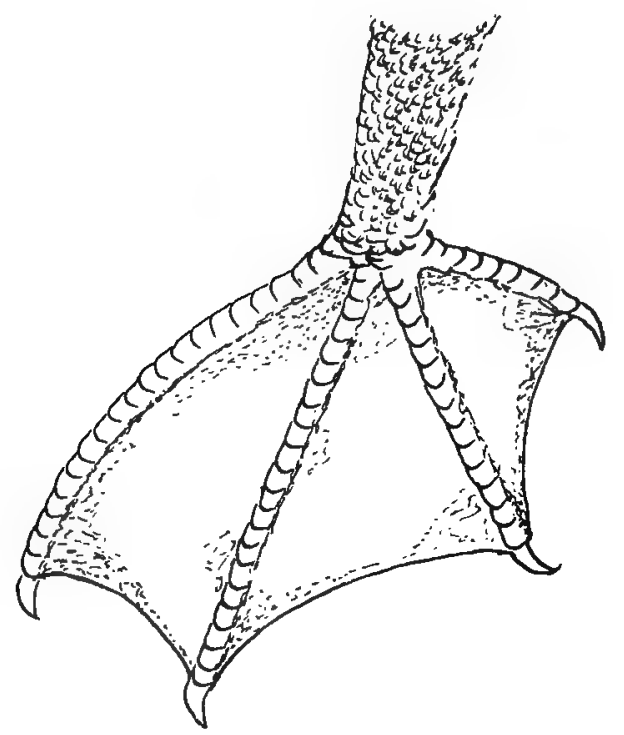

FIG. II5--Totipalmate foot of a pelican.

fed on the same diet, only the fish are smaller. Pelicans can be kept in confinement, and take to it not unkindly; but they must be provided with fish, and this would not be an unwelcome task provided it came in the spring-time and the attendant were a small boy. The tongue of the pelicans is extremely small, a mere knob of a tongue as in the kingfishers.

All of the Steganopodes, although some of them are extremely large, are especially light on the wing. The 
frigate birds are perhaps unsurpassed in their command of the wings in flight, although the albatrosses and the

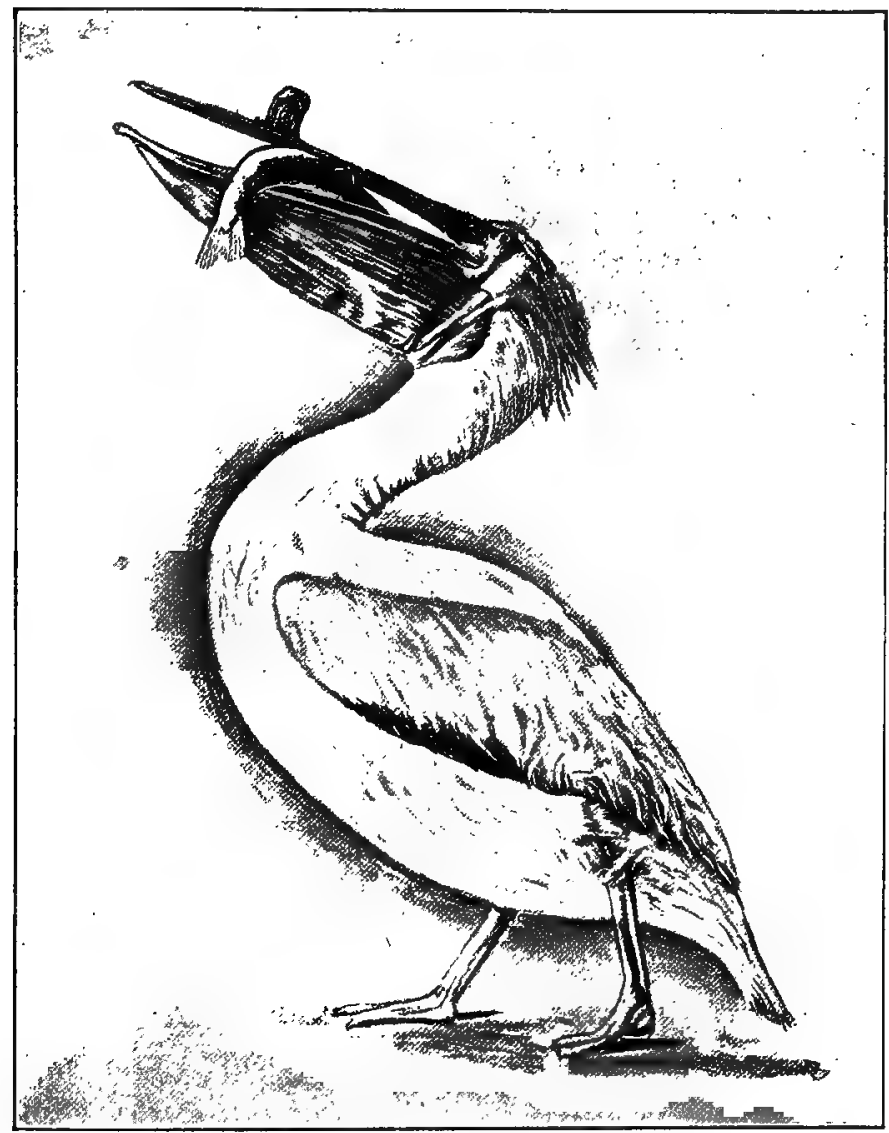

FIG. II6.-Pelican (Galloway). Photographed by J. W. Folsom.

petrels excel them in the ability to stay away from land for a longer time. Frigate birds are frequently seen hundreds of miles out to sea. This lightness of wing is attained by the extraordinary system of air tubes under- 
neath the skin, and the unusually large air cavities in the long bones of the wings and the legs; these are hollow for their entire length, being solid only at the ends where they enlarge to provide for attachment of muscles. If one presses the skin of a pelican in the pectoral or the ventral region, there is heard a crackling sound as the air is driven in and out of these enormously developed pneumatic reinforcements of the respiratory system.

The young of the order are altricial; the eggs are very few, in most species of the birds only one, plain colored and coated with a chalky-white substance. North America has ten species of cormorants, four of which nest within the United States; the Florida and the Mexican nesting in Florida and the Rio Grande country, respectively. Of the other two, the white crested and the common, the former nests in the northwest, Oregon; and the latter in the marshes of Iowa, Wisconsin, and some of the inland lakes. Pelicans build nests on the ground or in low bushes, cormorants on rock ledges or in crevices of some rocky cliff, or in bushes; frigate birds in low, thick bushes by the water's edge. The nests of the last are made of sea weeds, mud, small stones, sticks, bark, and grasses, usually placed on the ground by the water's edge or on islands. The white pelican spends its winters in our southern states along the Atlantic, in the Gulf states, and in Mexico.

The cormorants are social birds, often nesting in immense colonies, their nesting grounds are exceedingly offensive, owing to their uncleanly habits in using excrementitious matter for a partial covering for the eggs. The decomposition of this matter serves to raise the nest temperature sufficiently high for incubation while the bird is away from home. 


\section{CHAPTER XXXVII.}

\section{LONGIPENNES.}

\section{Long-winged Swimmers-Altricial.}

These are the long-winged swimmers; gulls, terns, petrels, and albatrosses, the wings, in many of the birds, reaching far back of the tip of the tail. The hind toe is elevated, very small, or absent, according to the representative bird of the order under examination, but there are but two .webbings. (Fig. I 7 .) These are all sea birds, excellent swimmers, and equally skillful on the wing. Gulls are often seen inland as well as along the sea-coast though most species are truly marine or nearly so. Their distribution is nearly worldwide. As to their habits, gulls may be classed as oceanic, or inland lake or river gulls.

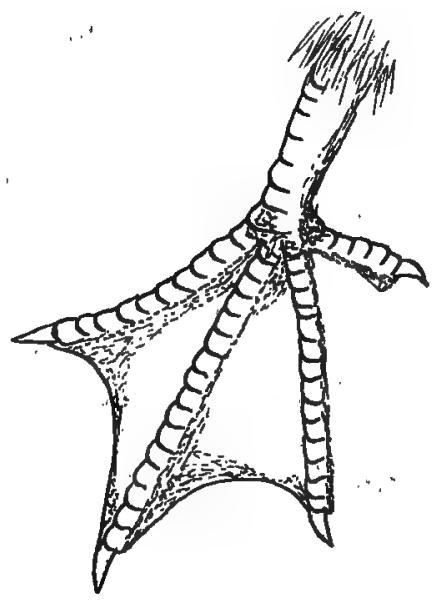
Bonaparte's gull, migrating, Fig. II7.-Palmate foot of a tern. may be found in localities reaching from the Atlantic to the Pacific; though it usually nests north of our northern boundary. Franklin's gull is inclined to nest inland. The inland water gulls, wintering, as many of them do, in Mexico, in coming north to Minnesota and Wisconsin, or to Manitoba for the nesting season, have been led, at least a few of them, 
to try a home in the interior states, and so may occasionally be found nesting as far from large water bodies as in Iowa and Kansas, the smaller lakes and ponds supplying their needs.

Terns, as a rule, nest on the fringing islands and in the marshes and lagoons from Greenland to Mexico, according to the species. The common tern, sometimes called the summer gull and the sea swallow, nests along many of the northern inland lakes as well as along the coasts. The ocean terns seldom fly far from land, and usually hollow out a depression in the sand for their nests. The petrels nest on the island-fringed coast of Maine, and from there northward. They come from their southern winter quarters in May. The nest may be a burrow in the sand or under a rock. These birds are small; they are often called sea swallows. During the incubating season, one bird sits on the nest during the day while the other bird is away feeding; during the night, it is thought the order is reversed.

The food of gulls consists of fish, young birds that may have died, the flesh of seals when it is obtainable, whale blubber, sea urchins, crabs, rabbits, and the eggs of cormorants, murres, and other sea birds. The ocean gulls fly far from land, and their long continued flight without return to land reminds one of the flight of the dragon flies over the surface of their miniature ocean. These are the birds that follow outgoing ships, and are rewarded by many a meal of refuse thrown overboard from the ship's galley. They are largely fish-eaters, but are also effective scavengers of the ocean. They have various nesting habits, building their nests of grass or sticks, sometimes placing it in trees, sometimes on stumps, and even on the ground. 
And these are also birds that, along with many other birds of beautiful plumage, are persecuted because of their fatal beauty. Recently there appeared in the New York Tribune, this, which ought to live in the memory of every child, and ought to arrest the attention of everyone: "The smaller gulls and sea swallows are shot for their wings, and the fowlers, in their haste, do not stop to kill any wounded birds; they merely wrench off the wings, and throw the wounded birds back into the water to die in agony. 'And,' says an eye witness, 'when wounded birds are being torn asunder, they cry and scream like a child." And this is at the demand of woman, at once the tenderest and the cruelest of God's created beings! 


\section{CHAPTER XXXVIII.}

\section{PYGOPODES.}

\section{Diving Birds-Præcocial and Altricial Birds.}

This is the order of the loons, the grebes, the auks, and the puffins. The first two are birds well known in the United States; the auks are arctic birds, and the puffins are mainly so, although the common puffin nests along our Atlantic coast from Maine northward, and the tufted puffin on our Pacific coast islands from Behring Sea down as far as the latitude of San Francisco. These birds have the most highly developed natatorial powers in the whole range of birds. The grebes swim and dive with perfect ease, and are also very skillful on the wing, though they do not use the wings in swimming, this, according to the observation of careful investigators, being done with the feet. The legs of all the birds of the order are set so far back that the birds, when on land, stand with the body nearly upright; the whole tarsus may then rest on the ground and the tail may be used for a prop.

All the different sorts of puffins are shy birds nesting on islands in almost inaccessible crevices in cliffs, except the common puffin, which nests on the ground. But even in the latter case, the ground burrows are usually located on some lonely island or little-frequented shore where flying is the surest method of travel. The auks are both coast and island nesting as to their habits; and, since their inclinations lead them to frequent lonely 
islands and rock-bound coasts accessible only in the face of great difficulty, they are not always so fearful of man as they should be for their own safety. With the exception of the razor-billed auk, the birds of this family are all inhabitants of the Pacific continental coasts and islands. The razor-billed auk nests on the Labrador coast, and on the North Atlantic and Polar sea islands. The Great Auk is one of the birds that has disappeared from the face of the earth within the memory of men now living, and its disappearance has been due to the fact of the diminutive wings. The shortness of its wings must have been a decided disadvantage to the birds in the case of combats with enemies among their bird neighbors, as well as a serious handicap in case of an attack made by man. During storms, also, the inability to use the wings must have resulted in the death of many of the birds. All the living auks have wings, and indications show that the ancestors of the Great Auk had useful wings; hence it is supposed that this bird lost the use of its wings through generations of disuse. The length of this bird was nearly three feet, thirty inches, and the length of its wing was just six inches, a wing-spread totally incapable of supporting the body of the bird free from the earth. This is the heavy penalty which nature always imposes. The Bible puts it-"He that will not work shall not eat"; and this law runs through the whole kingdom of life - a power unused becomes finally impossible. Among the body members, an organ unused degenerates in structure till it is incapable of fulfilling its function. This is one of the most serious lessons that the living being has to learn.

The loons are all northern birds, though the yellowbilled loon, the largest of them all, is the only one that 
may be called strictly arctic. The great northern diver is the most common loon in the United States. It nests in the states along our northern border on islands in the lakes and rivers. The parallel of forty-two degrees was formerly spoken of as its southern breeding limit, but of later years it has been found considerably south of this line. Not only is it found in the Adirondack region, in Michigan, and in Maine, but it also comes as far south as Nebraska.

The birds of the order are all excellent swimmers, but the loons and the grebes excel the others. A loon is so nearly instantaneous in its response to a stimulus that a bullet fired at hunter's range strikes the water after the bird has left the spot where the bullet enters the water. This expertness is shared by all the grebes, and as they sink below the water surface, hardly a ripple is left to tell where they sank. Both loons and grebes are capable of swimming extraordinary distances under water. The plumage of the birds is kept well oiled, and the oil naturally at the base of the feathers is so abundant that no amount of diving or swimming under water can unfit the birds for a further plunge.

The grebes are much more generally distributed over the continent than are any other birds of the order. The western grebe ranges over the whole western part of the United States from the Rio Grande country on the south to the Red River of the North, breeding in many of the inland lakes and streams. The pied-billed grebe, which has a black band around its bill midway of its yellowish-gray length, is another grebe of very wide distribution. It ranges from the provinces of British America to Chili and the Argentine country, spreading Atlantic-wise to the West Indies and the Bermudas. 
The hurned and the American eared grebe are a little more restricted in their range, being more western and less southern; the eared grebe coming no further south than Texas, and from there into British America; while the Horned Grebe comes no further south than along our northern boundary, with occasionally a visitor wandering down into northwestern Illinois. The western grebe, the pied-bill, and the dab chick-smallest of our grebesspend the winter far to the south of their nesting grounds, many of them wintering on Mexican waters, where they enjoy much more freedom from their enemies than can be found in the United States.

These grebes, especially the western, which is the largest of its tribe, are among the birds whose fatal endowment is beauty, many of them being killed annually for the beautiful silky plumage of the breast. Men who make it their business to kill these birds, make swift, cruel work of it. The body is not cold before the warm skin with its silky feathers is stripped from the breast which may have so lately covered a nestful of eggs or tender young.

Ever since man came among the animals of the earth, he has been the greatest agent of slaughter of the whole list. In his early days, he, of course, had to contend for the mastery with animals much stronger than himselfit was kill or be killed then, and no one of us could have blamed him then. But in these days he has so far forgotten his old bravery and honor of bearing himself among his kind, as to pursue to the death only the animals smaller and weaker than himself. The sportsman who cracks away at wooden pigeons to test his skill is the better man of the two.

The nest of the grebes is simply a mass of decaying 
vegetation, pulled up from the river bottom, and fastened like a tiny raft to the stems of reeds and rushes in shallow water. Upon leaving the nest in the morning, the mother grebe has the curious habit of pulling up from the bottom of the nest some of the grasses and decaying leaves to cover the eggs. During the day, the warmth of the sun's heat on the wet weeds serves to keep the eggs warm until the close of day. When surprised, the mother bird slips off the nest leaving the eggs unprotected. She simply hides and seems to make no effort to defend her home. The food of the whole order is mainly fish. The young loons and the grebes are præcocial, and early have somewhat the same skill as the adults in diving and swimming. The auks and the puffins are altricial, and anyone who has tried to enter a puffin's nest knows that the puffin is well able to defend her nest from all intruders.

This is the lowest order of birds; that is, these birds are farthest removed from the passerine birds as regards nervous organization, functional excellence in many lines instead of one line, and in closeness of relationship to man, both physiologically and economically. All these characteristics the passerine birds possess in the highest degree, and the Pygopodes in the lowest degree. It is also true that these birds come nearest to suggesting reptilian characteristics. Hesperornis, the early Cretacean bird of the United States, had the general build of the loons of this order. This shows the continuity of the processes by which the Creator has brought gradually into existence the different types of bird life, from the ancient Archæopteryx, more like reptile than bird; through Hesperornis, loon in build but incapable of flying; Ichthyornis with some features of the modern bird; 
to the earliest bird suggesting the passerine type; until to-day we have the birds of the present age, with such differently developed characteristics as to warrant our grouping them in the thirteen orders-Pygopodes, or diving birds; Steganopodes, or fully-web-footed birds; Lamellirostres, or duck-like birds; Longipennes, or longwinged swimmers; Alectorides, swamp and marsh birds; Herodiones, heron-like birds; Limicolæ, shore birds; Gallinæ, game birds; Columbæ, doves and their relatives; Raptores, birds of prey; Picarian birds; and the Passeres, crown and consumnation of development among the tribes of birds. 



\section{INDEX.}

Abdomen, 3

Acarina, 234

Alectorides, 334

Alimentation:

birds, 301

insects, 24

Altricial birds, $28 \mathrm{I}$

Ametamorphosis, 33, 40

Anis, 3 I 5, 343

Anopheles, I 93, I97, 201

Ant lion, 225

Ants, 164

artificial nest, 143

feeding habits, 165

forming of community, I 65

honey-gathering, I 66

individuals in community, I 65

industries, 166

life duration, 168

mother of community, 165

nests, 140

sense of smell, I 56

study of, $\mathrm{I}_{4} \mathrm{O}$

Aphis lion, 22 I, 222

Aptera, 43

Arthropoda, $231,238,252$

Arachnida, 238

Assassin bug, I 7

Auk, the great, $35^{\mathrm{I}}$

the razor-billed, $35 \mathrm{I}$

Aves, 2, 252

Back-swimmer, 99, I 12

Baldpate, 34 I

Baltimore oriole, 74, I 37, 259 , 293

Bark lice, I 8

Barn swallows, 97, 256

Bats, 200

Bee flies, 20I, 204

Bee jelly, I6o

Bees and water, 164

Bees, bumble, I43, I6 I
Bees, honey, I 55

colony founding, I 57

feeding of larvæ, 157

royal larva, I60

sense powers, I 55

study of, I 39

swarming, I 60

significance of, 162

Beetles, 67

habitats, 59, 60, 62, 67

Beneficial flies, I 88

Bembecidæ, I 69

Bill of a bird, 262

Biology defined, $\mathbf{r}$

Birds, 252

affection among, 282

alimentation, $30 \mathrm{r}$

ancient, 253

choice of a mate, 273

classification as to residence, 278

economic value of, 255,259 , 278,287

encouragement of, 73,74 , 278,294

feeding of young, 288

migrations, 274

nervous system, 296

nest-making, 284

notions of cleanliness, 285

physical features, 262

relationships, 253

respiration, 300

Birds of prey, 3 I 8

Bitterns, 33 I, 332

Blackbirds, $74,97,137,256,284$, $289,29 \mathrm{I}$

Blister beetles, 69,77

metamorphosis, 77

Bluebirds, 97, 137,256

Blue jays, $74,97,137,257,284$

Bobolink, 277

Bobwhites, 74, 97, II 5, I I 8, 28 $\mathrm{I}$,

Book lice, 44 
Borers, 59

bird enemies, 74

Bot flies, I 84 , I 88

Box elder bug, 40

Brain, lobes of, 296

biological significance of, $3 \mathrm{I}$, 296

Brown creeper, I I 8, 257, 294

Brown thrasher, 289

Bufflehead, 34 I

Bugs, I07

Bumble bee, I43, I6 I

Butcher bird, 97, 309

Buzzards, 3I 9

Cabbage worm, IоI, I09, I 37

Caddis flies, 45, $22 \mathrm{I}$

Calico back, ror, i I 8

Camponotidæ, I 66

Carpenter ant, I 65

Carpet beetles, 73

Carrion beetles, 60,69

Carrion crow, 319

Carrion flies, I 78

Catbird, $137,256,289$

Caterpillar musculation, 38

Caterpillars, I 20, I32, I 37,257

Centipeds, 2, 232

Checker beetles, 69

Chickadee, I I 8, I 37, 293

Chinch bug, I I 3

bird enemies, I I 5, II 8

disease of, I I 5

development of, I I 4

history of, II 3

natural enemies, I I4 range, II 3

Chippy, I 37

Chitin, 5

Chordata, 3

Cicada, Iо2, I I 8 , I 70

Cicada killer, I 70

Circulation of blood, birds, 303 insects, 23

Clamatores, 308

Classification of insects, 42

Clear-winged moths, I 25

Click beetles: bird enemies, 74

Cockroach tiger, 238

Codling moth, 7 I

Coelenterata, 2
Coleoptera, 43,67

characteristics, 65

life history, 77

mouth-parts, 76

value of the order, 68

Coloration of birds, $27 \mathrm{I}$

Color sense: bees, I I

flies, I I

Collecting boxes, 53

Collection box, 55

Columbæ, 320

Complete metamorphosis, 33, 39

Cooper's hawk, 29 I

Cormorants, $285,343,348$

Corrodentia, 44

Cosmopolitan, the, 138

Crabs, 238,348

Cranes, I $18,334,336$

Crayfish, 238

Cricket-like grasshoppers, 90

Crickets, 8I bird enemies, 97

Crow, 97, I 37,259

Crustaceans, 2,238

Crystalline lens of eye, 8

Cuckoos, 74, 97, I $37,256,3$ I 5 289,3 I 3

Cucumber beetle:

bird enemies, 74

Culex, 193, I97, 198, $20 \mathrm{I}$.

Curculios, 7 I

Curlew, 327,329

Cuticle, 5

Cutworm, 70, 73, 137, 290, 293

Daddy longlegs, 235

Darters, 343

Damsel bug, I I 3

Damsel flies, 207

Dermal light sense, Io

Dermestidæ, 7

Development, 32, $28 \mathrm{I}$

Digger wasp, I 68, I 7 I

Dipnet, $5 \circ$

Diptera, 183

characteristics, I 8 I compound eyes, I 86 divisions of, 187 feeding habits, I 78 , I 84 metamorphosis, 186

Diving beetles, 63,69

Diving birds, 350 
Dobsons, 223,224

Doves:

domestic, 320

mourning, $32 \mathrm{I}$

Downy woodpecker, 74, I I8, 257,294

Dragon flies, 200, 207, 209

characteristies, 207

development, 209,2 I 1

distribution, 2 I 2

feeding habits, 208

nymph, 2 I I

sight, 208

life duration, 2 I I

Drone bees, I 56, I 59, I 6 I, I 63

Ducks, 337

domestic, $97,338,342$

wild, $339,340,34 \mathrm{I}$

Dung beetles, 69

Eagles, 318, 3 I9

Ear:

$$
\begin{aligned}
& \text { bird, } 299 \\
& \text { locust, I } 7, \text { I } 8 \\
& \text { mosquito, I } 8
\end{aligned}
$$

Earwigs, 44

Echinodermata, 2

Egg, insect, 32

Egret, 332 hunting of, $33^{2}$

Eider duch, 339

Electric light bug, I I 2

Elm leaf beetle: bird enemies, 73

life history, 73

Elytra, 67

English sparrow, 74, I37, 284, 290, 3 I0

Entomology, 42

Ephemerida, 2 I 3 characteristics, 2 I 3

immature respiration, 2 I 3

metamorphosis, 2 I 4

reasons for persistence, 2 I 3

Eriocephalas, I 29

Eumenidæ, r 74

Euplexoptera, 44

Eye:

compound, 7

development of, 9 , I0

lack of, 7

number of facets, 7

of bird, 297
Eye:

of grasshopper, 6

simple, 9 , Io

False rear horses, 225

Feet of birds, 264

Filed work:

bees, ants, wasps, I 39

beetles, 59

butterflies, I I 9

birds, 249

flies, I 76

grasshoppers, 79

bugs, 98

insects in general, 46

Fireflies, 63, 69

Fish duck, 337

Fishes, 2, $200,260,296$

Fleas, 226

Flickers, 74, 294

Flies, 183 setting for collection, I 79

Flower beetle, 62, 69, 76

Flower bug, I 14 , I I 6

Flower fly, I $78,201,202$

Flycatchers, 257

Flying spiders, 243

Food of nestling birds, 287

Fowls, domestic, 74, 97, 342

Frenatæ, I30

Frigate bird, 343

Function of accommodation: in birds, 297

Gall flies, I49, I 53, I 54, 234

Gall-forming insects, 234

Gallinæ, 322 characteristics, 323

Galls, I 53, I 55, 234

Gannets, 343

Geese, wild, 337, 339

Giant waterbug, I0o

Gnats, I 84, I 88, 257

Golden-eye, 222

Goldfish, 200

Goshawk, $258,29 \mathrm{I}$

Grasshopper, 3, 87 bird enemies, 97 insect enemies, $82,20 \mathrm{I}$

Grass stem flies, I 92

Grebes, 264, $35^{\circ}$ hunting of, 353 
Grebes, nests, 353 range, $35^{2}$

Grosbeaks, 292

Ground beetles, 69, 7 I

Grubs, 73 bird enemies, 74

Gulls, 347,348

Gypsy moth, 70, I 37

Hairy woodpecker, 74, I I 8, 257 ,

Halteres, 184

$$
\begin{array}{r}
294 \\
184
\end{array}
$$

Hand lens, 5I

Handmaid moth, larva, I34

Harmful flies, I 88,204

Harvestmen, 235

Hawks, $25^{8}$

$$
\text { marsh, I 37, I 64, 258, } 292
$$$$
\text { night, } 97,3 \text { I } 3
$$

red-tail, $137,258,292$

Hearing:

sparrow, $97,258,29 \mathrm{I}$

Heart:

$$
\text { birds, } 299
$$$$
\text { insects, I7 }
$$

Hemiptera, 107

beak of, 99, 108

beneficial, Io9, I I 2, I I 4, I I 7

characteristics, 105

development, I09

divisions of order, I07

food habits, 108, 109

harmful sorts, Ir 8

setting for collection, 104

Hepialidæ, I 29

Herodiones, 33 I

Herons, 332

Hesperornis, 254, 354

Hessian fly, I 9 I

development, I 9 I

measures against, I 92

natural enemies, I92

Hippelates, 192

Homing instinct, I I, I 3 , I39, I 56

Honey, I 57

Honey ants, I 66

Honeybees, I 55

House fly, I 88, I 90 measures against, r 90 metamorphosis, 190

House wren, 97, I I 8, I 37
Horse fly, r 84,188

Humming bird, 3 I 2,3 I 5

Hunter, the Fiery, 70

Hypermetamorphosis, 34

Hymenoptera, 43, I49 characteristics, 147 subordination of males, I 54 , I 68,173

metamorphosis, I 54

mouth-parts, I 53

ovipositor, I 54

sense powers, 156

wing action, $\mathbf{5}^{2}$

Ibis, white-faced glossy, 333

Ichneumon flies, I49, 150

Ichthyornis, 256,354

Incubation, $28 \mathrm{I}$

Incomplete metamorphosis, 40

Industries of the hive, I 62

Insect net, 49

Insects, 2, 238

Isoptera, 44

Jigger fleas, 226

Jointer spiders, 235 characteristics, 235 palpi, 236

Jugatæ, I 29

June bug, $59,74,78$ bird enemies, 74

Katydids, 87, $9 \mathrm{I}$ bird enemies, 97

Key to families of spiders, 246

Killing bottle, $5 \mathbf{I}$

Kingbird, 74, 97, 29I

Kingfisher, 3 т 3

King rail, 335

"Kissing bug," I I 7

Labels, 56

Labium, 4, 6

Labrum, 2, 6

Lace-wing, 22 I, 222

I.adybird, 69

Lamellirostres, 337

characteristics, 337

divisions, 337

food, 338

migrations, 339 
Larvæ, 34, 4 I

Leaf bugs, I I I, XI 3

Leaf chafers: bird enemies, 73

Lepidoptera, I 25 biological relationships, I 30 characteristics, I 23

distribution, 138

larval food-getting, $\mathbf{I}_{32}$

metamorphosis, I 3 I

mouth-parts, I 66

primitive lepidopters, I 29

setting for collection, 122

value of order, 132

wing action, 29

Light, dermal sense, ro

effect on animals, 102

Limicolæ, 327

bill, 327

characteristics, 327

food, 329

migrations, $33^{\circ}$

nesting habits, 329

Linnæus, 42

Lizards, 259

Lobstera, 238

Locust, setting for collection, 82

Longipennes, 347

characteristics, 347

food, 348

Loons, $35 \mathrm{I}$

Lubbock, I 4 I

Luna moth, I 34

Mallard, 342

Mallophaga, 44

Mandibles, 4

Marsh hawk, 256, 292

May beetle, 59, 73

bird enemies, 73,74

May flies, 2 I 3

Maxillæ, 4

Meadow lark, II8, I 37

Merganser, 337

Measuring worm, I 35

Metamorphosis, 33

Metazoa, I

Midas flies, $20 \mathrm{r}$

Migrations of birds, 274

directions within United States, 274

guiding sense, 279

mode of travel, 274,279

significance of, 274
Millipeds, 23 I

Minnows, 200

Mites, I 44, 234

Mocking bird, 289

Mollusca, 2

Monarch butterfly, I 35

Monogamy among birds, 280

Mosaic sight, 8

Mosquitoes, I 76, I 93

development, I 94

hibernation, I 99

immature respiration, I95

malarial sort, 198

natural enemies, 200

preventive measures, I 76 , $20 I$

scales on wings, 197

sex distinctions, I 98

economic sorts, 193

Moths, I2 5

Mourning dove, $32 \mathrm{I}$

Mouth-parts:

bees, ants, wasps, I 53

beetles, 76

bugs, 99 , 108, I 26

dragon flies, 209

fleas, 226

flies, 184

grasshoppers, 4, 87

May flies, 2 I 3

moths and butterflies, I 26

Neuroptera, 22 I

spiders, 231

stone flies, 2 I 7

Mud-daubers, 168

Muscles of grasshopper, 2, 3

Myriapoda, 23I, 238

Naphtha, 55

Nectar, I 58, I 64

Nictitating membrane, 297

Negro bugs, I I 3

Nervous system:

birds, 296

insects, 28

Nesting season of birds, 280,287

Nestling birds, food of, 287

Nest-making of birds, 284

Neuroptera, 43, 22 I characteristics, 2 I 2 development, 2 I 3 feeding habits, 2 I 3 relationships, 2 I 2

- value of the order, 2 I 5 
Nuthatches, 294

Odonata, 207

Optic nerve, 8

Orders of birds, 305 of insects, 57

Orientation, 279

Orioles, I $37,257,293$

Orthoptera, 43, 87 characteristics, 85 bird enemies, 97 metamorphosis, 87

Oscines, 308 mouth-parts, 87

Ostrich, 266, 282

Owls, 258

$$
\begin{aligned}
& \text { barn, } 292 \\
& \text { screech, } 99, \text { I } 37,292
\end{aligned}
$$

Palpi, 5

Parasitism, I 49, I 50

Paroquet, Carolina, 3 I 6

Parrots, 3 r 6

Passenger pigeon, $32 \mathrm{I}$

Passeres, 307,355

biological position, 308,3 I I characteristics, 307 economic value, 3 I I

Pelicans, $30 \mathrm{r}, 343$

Pen-marked sphinx, I 33

Phalangina, 235

Pheasant, Mongolian, 74, 293

Phobe, 74

Physopoda, 44

Picaria, 3 I 2

Pici, 3 I 3

Pigeon horntail, I 50

Pigeons, 320

Pillbug, 238

Pink eye, I 92

Plecoptera, 2 I 7 adult characteristics, 2 I 7 development, 2 I 7

feeding habits, 2 I 8

nymphal characteristics, 2 I 7

Plovers, 327

Plumage of birds, $27 \mathrm{I}$

Pollen gathering by bees, $16_{3}$

Polygamy among birds, 280,342

Pomace flies, I 93

Potato beetle, 73,78

bird enemies, 74

Præcocial birds, $28 \mathrm{I}$
Prairie chickens, 74, 97, I I 8, 322

Prairie squirrels, 259

Praying mantids, I4, 82, 94

Primaries, 270

Primitive ground sense, Io

Propolis, I64

Protective colors: birds, 272, 327 insects, 12,79

Protozoa, I

Psittaci, 3 I 6

Puffins, $35^{\circ}$

Pupa, 33,36

Pygopodes, $35 \mathrm{I}$

Quail and chicken experiment, Quails (see Bobwhites)

Queen cells of honey bees, I 59

Rails, 334

Raptores, 3 I 8

Reading glass, $5^{\circ}$

Recognition colors: insects, 7

Rectrices, 268

Red-tailed hawk, 258,292

Regal moth, I 34

Respiration: birds, 300 insects, 20 rate of, 23,308

River fluke, 290

Roaches, 92 development, 94 food habits, 94 foreign and native, 93

Robber flies, 203

Robins, 74, 97, 137, 256,267

Rose-breasted grosbeak, 74, 290

Rose chafers, 73

Rove beetles, 62,69

Sandpipers, 327 spotted, 329

Sawflies, I 49, I 54

Scale insects, IO3, I IO bird enemies, I I 8

Scales, I 25

Sclerites, 3, 6

Screech ow1, 97, 137, 292

Scorpions, 236 
Searcher, the, 70

Secondaries, 270

Sharp-shinned hawk, 29 I

Shield-backed bugs, I I 3

Shield-backed grasshoppers, 90

Shrimps, 238

Shore birds, 327

Silkworm moth, I 33

Simple body type, 5, 28

Siphonaptera, 226 characteristics, 226 development, 227

parasitism, 226

relation to bubonic plague,

$$
229
$$

Skeleton of insects, 5

Skunk, 260

Smell, sense of:

birds, 298

insects, I I, 299

Smelling organs:

birds, 299

insects, 12

Snails, 290, 329, 33 I

Snake flies, 22 I

Snakes, value of, 68

Snipes, 327

Soldier beetle, 69

Soldier bug, I 7

Soldier fly, I 88, 203

Solpugida, 235

Song sparrow, 27 I

Sparrow, English, 74, I37, 290 ,

$$
3 \text { I0 }
$$

Sparrow hawk, 97, 256,29 I

Sparrows, 74, 97, I 18, I 37,256 , 290

Special senses, 7, 296

Species, 272

Sphecina, I 68, I 7 I

Sphinx moth, I 33

Spiders, 2, 238

characteristics, 238

development, 244

food habits, 240

mouth-parts, 239

non-sociability, 240

poison glands, 239

respiration, 239

sense of, 240,242

spinning habit, 242

spinning organs, 244

Spider wasps, I 68

Spiracular system of insects, 2 I
Squash bug, 4I, I OI, I I 8

bird enemies, $6 \mathrm{I}$

Stable flies, I 89

Steganopodes, 343

Sticklebacks, 200

Stink bugs, I I 7

Stone flies, 217

Storks, 33 I

Stridulation, 89

Struggle for existence, I 32

Sunfish, 200

Swallow, barn, 97, 256

Swallow-tail, black, I 35

Swan, 337, 339

Swarming of bees, I 60

Sympathetic system:

birds, 297

insects, 29

Tachina flies, $20 \mathrm{I}$

Tail of bird, 267

Tarantula killer, I $7^{\circ}$

Taste:

birds, 300

insects, I 6

Tent caterpillars, I 34, I 37

Termites, 44

Terns, 347

Thalessa, big, I 50

Thorax, 2

Thread-legged bug, I I 3

Tread-waisted wasp, I 68

Thrips, 44

Thysanura, 44

Ticks, 2, 234

Tiger beetle larva, 60

Toads, 259

Tobacco worm:

$$
\begin{aligned}
& \text { adult, } 37 \\
& \text { egg, } 34 \\
& \text { larva, } 35 \text {. I } 33 \\
& \text { pupa, } 36
\end{aligned}
$$

Touch:

birds, 300

insects, I 3

man, I 4, I 5

Towhee, 74, 97, 290

Trap-door spider, 24 I

Tree cricket, 80

Tree duck, 34 I

Trichoptera, 44

Tumble bugs, $60^{\circ}$

Turkey, wild, 326 
Vanessa cardui, I.38

Vespina, I 68, I 72

Vireo, I 37,256

Vital processes:

birds, 300

insects, 20

Vulture, black, 259, 3 I 9

Walking sticks, 5I, 95

Warblers, I 37, 2 56, 293

Wasp flies, 188,203

Wasps, I 63 community life, I 73 industries, I 73 , I 74 nests, I72, I 74 paper-making, I 75 sense powers, I 72 social, I 72 solitary, I 68 study of, I 44

Water boatman, 99
Water scavengers, 61, 60

Water scorpions, I I 2

Water striders, 98

Wax-making of bees, I $6_{3}$

Webs of spiders, 242

Weevils, 73 bird enemies, 74

Whip-poor-wills, 257

Whip-tailed scorpion, 237

Whirligigs, 63

White ants, 44

White grubs, $59,73,74$

Wing of bird, 268 comparison, 269

Winter birds, value of, 278

Wire worms, 74

Woodcock, 328

Wood duck, 282

Woodpeckers, 74, I I $8,257,294$, 3 I 3,342

Zoology defined, I 


\section{IMPORTANT EDUCATIONAL BOOKS}

Biology, Botany, Bacteriology, Chemistry, Physics,

Physical Education, Anatomy, Embryology,

Histology, Physiology

P. BLAKISTON'S SON \& CO., Publishers

Books on Science and Medicine

1012 Walnut Street, Philadelphia

\section{BIOLOGY.}

ENTOMOLOGY: With Special Reference to Its Biologic and Economic Aspects. By Jusxus W. Forsom, SC.D. 5 Plates, 1 Colored; 300 other Illustrations. Octavo; 485 pages. Cloth, $\$ 2.00$ net.

TEXT-BOOK OF ZOOLOGY. Second Edition. By T. W. Galloway, A.M., PH.D. 240 Illustrations. Octavo; xii +481 pages., Cloth, $\$ 2.00$ net.

A LABORATORY TEXT-BOOK OF ZOOLOGY. Loose-leaf System. By Theo. H. Scherfer, A.M. Second Edition. Octavo. Adjustable Cloth Covers, \$0.75 net.

NERVOUS SYSTEM OF VERTEBRATES, By JOHN BLACK JOHNSTON, PH.D. 180 lllustrations. Octavo; 370 pages. Cloth, $\$ 3.00$ net.

\section{BOTANY.}

PLANT ANATOMY from the stand-point of the Development and Functions of the Tissues, and Fandbook of Microtechnic. By WM. C. STEVENS, M.S. 136 Illus. 8vo; 349 pages. Cloth, $\$ 2.00$ net.

VEGETABLE PHYSIOLOGY, An Introduction to, By J. REYNOLDS GRETN, Sc.D., F.R.S. Second Edition. Revised. 182 Illustrations. Octavo; 459 pages. Cloth, $\$ 3.00$ net.

ORGANIC MATERIA MEDICA AND PHARMACOGNOSY. An introduction to the Study of the Vegetable Kingdom and the Vegetable and Animal Drugs. Comprising the Botanical and Physical Characteristics, Source, Constituents, Pharmocopoial Preparations; Insects Injurious to Drugs, and Pharmacal Botany. By L. E. SAYre, B.S., PH.M. With Sections on Histology and Microtechnic by WILliaM C. STevens. Thira Edition. Revised. 377 Illustrations, the majority of which are from Original Drawings. $8 v 0 ; 675$ pages. Cloth, $\$ 5.00$ net.

MEDICINal PLANTS OF THE PHILIPPINES. By T. H. Pardo Dh Tayera, Translated and Revísed by JEROME B. THOMAS, JR., A.B., M.D. 12mo; 268 pages. Cloth, $\$ 2.00$ net.

\section{BACTERIOLOGY,}

BACTERIA IN MILK AND ITS PRODUCTS. By H. W. ConN, Ph.D. 43 Illustrations. $12 \mathrm{mo}$; 306 pages. Cloth, $\$ 1.25$ net.

AGRICULTURAL BACTERIoLOGY. Including a. Study of Bacteria as Relating to Agriculture, with Special Reference to the Bacteria in Soil, in the Dairy, in Food Products, in Domestic Animals, and in Sewage. Second Edition. By H. W. CoN N, PH.D. 64 Illustrations. 12mo; $\mathbf{x}+$ 331 pages. Cloth, $\$ 2.00$ net.

PRACTICAL BACTERIOLOGY, BLOOD WORK AND ANIMAI PARASITOLOGY; Including Bacteriological Keys, Zoological Tables and Explanatory Clinical Notes, By E. R. STITT, A.B., PH.G., M.D. With 86 Illustrations. $12 \mathrm{mo}$; $\mathrm{xl}+294$ pages. Flexible'Cloth, $\$ 1.50$ net. 
A MANUAL OF BACTERIOLOGY: With Special Attention to Bacterial Polsons and Immunity. By HRrBeirT Williams, M.D. Revised by B. Meado Bolton, M.D. Fifth Edition. 111 lllustrations. 12mo; 466 pages. Cloth, $\$ 2.00$ net.

BACTERIOLOGY AND THE PUBLIC HEALTH. By GqoRge NWWMAN, M.D., F.R.S.E., D.P.H. Thfrd Edition. 31 Full-page Plates and 48 other Illustrations. Octavo. Cloth, $\$ 5.00$ net.

COMPEND OF BACTERIOLOGY, INCLUDING ANIMAL PARASITES, By $R$. L. Pitmield, M.D. 4 Plates containing 56 Figures, and 80 other Illustrations. $12 \mathrm{mo} ; 232$ pages. Cloth, $\$ 1.00$; interleaved for the addition of notes, $\$ 1.25$ net.

INFECTIOUS AND PARASITIC DISEASES, An Introduction to. By MILLARD LANGFELD, A.B., M.D., with an introduction by LEWELLYS F. BARKER, M.D., of Johns Hopkins University. 33 Illustrations. 12mo; 260 pages. Cloth, $\$ 1.25$ net.

\section{CHEMISTRY.}

A LABORATORY GUIDE TO THE STUDY OF QUALTTATIVE ANALYSIS, Based upon the Application of the Theory of Electrolytic Dissociation and the Law of Mass Action. By E. H. S. BaILey, PH.D., and HaMiLTON P. CADT, PH.D. Fifth Edition. Illustrated. 8vo; 278 pages. Cloth, $\$ 1.25$ net.

THE PRINCIPLES OF QUAIITATIVE ANALYSIS. From the Standpoint of the Theory of Electrolytic Dissociation and the Law of Mass Action. By Dr. WilHelm BoTtgin. Translated by William G. SMeaton, A.B. Illustrated. Octavo; 300 pages. Cloth, $\$ 2.00$ net.

FOOD ANALYSIS, Illustrated. Select Methods in Food Analysis. By HenRy Lefrmane, M.D., Professor of Chemistry in the Woman's Medical College of Pennsylvania and in the Wagner Free Institute of Science; Phlladelphia; and WILLIAM BEAM, A.M. Second Edition, Revised. With many Tables, 1 Plate and 54 other Illustrations. 12 mo; iv +396 pages. Cloth, $\$ 2.50$ net.

THE DETECTION OF POISONS AND STRONG DRUGS, A Laboratory Guide. Including the Quantitative Estimation of Medicinal Principles in Certain Materials. By DR. WrLHELM AUTHNREITH, University of Frelberg, Baden. Authorized Translation from the Third German Edition by WILliaM H. WARREN, A.M., PH.D. (Harv.), Professor of Chemistry, Medical Department, Washington University, St. Louis. IJlustrated. 12mo; xil +222 pages. Cloth, $\$ 1.50$ net.

QUANTITATIVE CHEMICAI ANAIYSIS. Adapted for Use in the Labolatories of Colleges and Schools. By FRANR CLOWES, SC.D., and J. BERNARD CoLEMAN, A.R.C.Sc. Dighth Edition. $12 \mathrm{mo} ; \mathbf{X X V}+565$ pages.
133 Illustrations. Cloth, $\$ 3.50$ net.

A TEXT-BOOK OF ORGANIC CHEMISTRY, By HENRT LEFFMANN, A.M., M.D., and Charles H. LaWall, PH.G.' 12mo. Cloth $\$ 1.00$ net.

PHYSTOLOGICAL CHEMISTRY, By JOHN HARPdr LONG, M.S., Sc.D. Second Edition, Revised. Illustrated. 8vo; vill + 396 pages. Cloth, $\$ 2.50$.

ELEMENTARY ANALYTICAL CHEMISTRY, QUALITATIVE AND VOLU. METRIC. By JOHN H. LONG, M.S., Sc.D. Third Edition. 10 Illustrations. $12 \mathrm{mo} ; \mathrm{x}+297$ pages. Cloth, $\$ 1.25$ net.

ELEMENTS OF GENERAL CHEMISTRY, WITH EXPERIMENTS. BY JOHN H. LoNG, M.S., ScD. Fourth Edition, Revised. 33 Illustrations. 12mo; $\mathrm{x}+443$ pages. Cloth, $\$ 1.50$ net.

ORGANIC CHEMISTRY: Carbon Compounds. By Prof. Victor VoN RICHThR. Translated by EDGAR IF. SMITH, M.A., PH.D. SC.D. Revised and Enlarged. Illustrated. 12mo. T"wo Volumes-Aliphatic Serles, and Carbocyclic and Heterocyclic Series. Each, Cloth, $\$ 3.00$ net. 


\section{IMPORTANT EDUCATIONAL BOOKS}

INORgANIC CHEMISTRY. By PROF. VICTOR VON RICHTER. Translated by Edgar F. Smith, M.A., Ph.D., Sc.D. Fifth Edition. Colored Spectra Plate and 68 other Illustrations. 8vo; 430 pages. Cloth, $\$ 1.75$ net.

QUALITATIVE CHEMICAL ANALYSIS OF INORGANIC SUBSTANCES. With Explanatory Notes, By OLIN Frmeman Townr, Ph.D. Octavo. Cloth, $\$ 1.00$ net.

ELeCtro-ANaIYSIS. By Edgar F. Smtth, M.A., PH.D., Sc.D. 4th Edition, Revised and Enlarged. 42 illustrations. $8 \nabla 0 ; 346$ pages. Flexible Leather, $\$ 2.50$ net.

EXPERIMENTS ARRANGED FOR STUDENTS IN GENERAL CHEMISTRY. By Edgar F. SMrth, M.A., PH.D., Sc.D., and Dr. H. F. Keller. Fifth Revised Edition. 40 Illustrations. Cloth, $\$ 0.60$ net.

vordmetric arazysis. Second Edition. By Virgil Coblentz, Pr.D., and ANTON VoriseK, PH.D. Illustrated. Octavo. viii +234 pages. Cloth, $\$ 1.75$ net.

PRACTICAL PSYSIOLOGICAL CHEMISTRY, A Laboratory Hand-book, designed for use in Courses in Practical Physiological Chemistry in Schools of Medicine and Science. By P. B. HAWK, M.S., PH.D. 2 Plates of Absorption Spectra in Colors. 4 other Colored Plates and 126 Text Figures of which 12 are in Colors. Second Edition Revised and Enlarged. Octavo. Cloth, $\$ 2.50$ net.

EXPERIMENTAL CHEMISTRY. A Text-book of (with Descriptive Notes), for Students of General INORGANIC CHEMISTRY, By EDWIN LEE. Illustrated. $12 \mathrm{mo} ; 433$ pages. Cloth, $\$ 1.50$ net.

A SYSTEMATIC HAND-BOOK OF VOLUMETRIC ANALYSIS. For the Quantitative Estimation of Chemical Substances by Measure, Applied to Liquids, Solids and Gases. Adapted to the Requirements of Pure Chemical Research, Pathological Chemistry, Pharmacy, Metallurgy, Photography, etc., and for the Valuation of Substances Used in Commerce, Agriculture and the Arts. By Francis Sutron, F.C.S., Ninth Edition. 121 Illustrations. $8 \mathrm{vo} ; 617$ pages. Cloth, $\$ 5.00$ net.

\section{PHXSICS.}

TEXT-BOOK OF PHYSICS. Second Revised Edition. Edited by A. WILMer DurF, A.M., Sc.D. Small Octavo. Mechanics. Bg A. WILMer DufF, Sc.D. Heat. By KarL E. GUTHE, PH.D. Sound. By Wrlliam HaL LOCK, PH.D. Iight and Wave Theory. By E. Percival Lewis, Ph.D. Electricity and Magnetism, By ARTHU R W. GoODSPRED, PH.D. Electromagnetic Induction. By ALBERT P. CARMAN, Sc.D. Conduction of Electricity Through Gases and Radio-activity. By R. K. MCCLUNG, Sc.D. 525 Illustrations. $\mathrm{xi}+698$ pages. Cloth, $\$ 2.75$ net.

A TEXT-BOOK, WITH EXPERIMENTS, ON CONDUCTION OF ELECTRICITY THROUGH GASES AND RADIO-ACTIVITY, By R. K. MCCIUNG, M.A., D.SC. 78 Illustrations. Octavo. xvi +245 pages. Cloth, $\$ 1.50$ net.

THE RECENT DEVELOPMENT OF PHYSICAL SCIENCE, By WILLIAM CECIL D. WhETHAM, M.A., F.R.S. 10 Full-page Plates, including frontispiece and portraits of Kelvin, Gibbs, Van't Hoff and Thomson, and 33 Text Figures. 12mo; 344 pages. Cloth, $\$ 2.00$ net.

A TEXT-BOOK OF PHYSICAI CHEMISTRY. By ARThUR W. EWELI, PH.D. 102 Illustrations. Small Octavo. ix +370 pages. Cloth $\$ 2.25$ net.

PHYSICAL EDUCATION.

PHYSICAL EDUCATION BY MUSCULAR EXERCISE. Bg LUTHER HaLseY GULICK, M.D. Illustrated. 8vo. Cloth, $\$ 0.75$ net.

LATERAL CURVATURE OF THE SPINE, AND ROUND SHOULDERS, THEIR CAUSE, PREVENTION AND TREATMENT BY GYMNASTIO EXERCISES. BJ ROBERT W. LovetT, M.D. 154 Illustrations. 8vo. Cloth, $\$ 1.75$ net. 
ANATOMY, EMBRYOLOGY, HISTOLOGY, PHYSIOLOGY.

MAMMALIAN ANATOMY: With Special Reference, to the Anatomy of the Cat. Second Edition. By Alvin Davison, A.M., Pr.D, With a Glossary and 114 Illustrations. $12 \mathrm{mo}$; xili +246 pages. Cloth, $\$ 1.50$ net.

COMPEND OF HISTOLOGY. Specially Adapted for the Use of Medical Students and Physiclans. By H. E. RADASCF, M.D. Second Revised Edition. With 127 Handsome Illustrations. $12 \mathrm{mo} ; x v+350$ pages. Cloth, $\$ 1.00$; interleaved for the addition of notes, $\$ 1.25$.

ANATOMICAL NOMENCLATURE. With Special Reference to the Basle Ana tomical Nomenclature [BNA]. By LEWELLYS F. BAREER, M.D., of Johns Hopkins University. Vocabularies in English and Latin. Two Colored and other Illustrations. Octavo. Cloth, $\$ 1.00$ net.

HUMaN aNaTomy. Edited by Henry Morris, M.A., M.B., and J. PlayFAIR MCMURRICH, A.M., PH.D. Fourth Edition, Rewritten, Revised and Enlarged. 1025 Illustratlons; 319 in Colors. One Octapo Volume. Cloth, \$6.00 net. (Or in 5 Parts, as follows: Part I. MorphogenesisOsteology-Articulation. Cloth, 1.50 net. Part II. Muscles-Organs of Circulation-Lymphatics. Cloth, $\$ 2.00$ net. Part III. Nervous System-Organs of Special Sense. Cloth, \$1.50 net. Part IV. Organs of Digestion-Organs of Voice and Respiration-Urinary and Reproductive Organs-The Ductless Glands-The Skin and Mammary Gland. Cloth, $\$ 1.50$ net. Part V. Surgical and Topographical Anatomy. Cloth, $\$ 1.00$ net.

ANATOMY FOR NURSES. By ELIZABETH R. BUNDY, M.D. With 191 Illugtrations, 34 in Colors. 12mo; 252 pages. Cloth, $\$ 1.75$ net.

ANATOMY OF THE BRAIN AND SPINAL CORD, with Special Reference to Mechanism and Function. By HARRIS E. SANTEe, M.D., PH.D., Professor of Anatomy in the College of Physicians and Surgeons of the University of Illinois. Fourth Edition. Rewritten and Enlarged. 128 Illustrations of which 33 are in colors. Octavo; 453 pages. Cloth, $\$ 4.00$.

A IABORATORY GUIDE FOR HISTOLOGY. Outlines for the Study of Mistology and Microscople Anatomy. By IRving HARDESTY, A.B., PH.D. With a Chapter on Laboratory Drawing by ADELDBRR WATTS LED, M.D. 30 Illustrations, 2 in Color. Octavo. Cloth, $\$ 1.50$ net.

TEXT-BOOK OF HISTOLOGY, Arranged upon an Embryological Basis. By DR. FREDERIC T. LEWIS, of Harvard Medical School. By Dr. PHILIPP STOHR. Sixth Amerlcan Edition, Revised. 450 Illustrations, 45 in Colors. 8vo; 434 pages. Cloth, $\$ 3.00$ net.

TEXT-BOOK OF PHYSIOLOGY. Illustrated, Third Edition. Especially adapted for the use of Students. By A. P. BRUBakm, M.D. With an Appendix giving a brief account of some essential forms of apparatus suited to those who have not large laboratory opportunities. 3 Colored Plates and 383 other Illustrations. Octavo; 752 pages. Cloth, $\$ 3.00$ net.

OUTLINES OF PHYSIOLOGY, By EDWARD GROVIS JONEs, M.D. Revísed by R. G. STEPHEN. 2d Edition. 107 Illus. 12mo. Cloth, $\$ 1.50$ net.

THE DEVELOPMENT OF THE HUMAN BODX. A Manual of Human Embryology. By J. Playfair McMoRrich, A.M., PH.D., Professor of Anatomy. Unlversity of Toronto, Formerly Professor of Anatomy, Unlversity of Michlgan ; Ealtor of Morris" "Text-Book of Anatomy." "Third Edition, Revised. 277 Illustratlons. Octavo; 528 pages. Cloth, $\$ 3.00$ net.

EMBRYOLOGY, A Laboratory Text-Book of Embryology. By CharLis $\mathbf{S}$. MINOT, S.D., LL.D., Professor of Histology and Human Embryology, Harvard Medical School. With 218 Illustrations. Cloth, $\$ 4.50$ net.

Prices given in this List are striotly net. Any book will be sent to any address, transportation prepaid by us, upon recelpt of the amount advertised. Catalogues of works on Blology, Chemistry, Medicine, etc., free upon applica-
tion. 







